\title{
FORAGE PRODUCTION AND DIVERSIFICATION FOR CLIMATE-SMART TROPICAL AND TEMPERATE SILVOPASTURES
}

\author{
A Dissertation \\ presented to \\ the Faculty of the Graduate School \\ at the University of Missouri-Columbia \\ In Partial Fulfillment \\ of the Requirements for the Degree \\ Doctor of Philosophy \\ by \\ RYAN H. DIBALA \\ Dr. Shibu Jose, Dissertation Supervisor
}

MAY 2019 
The undersigned, appointed by the dean of the Graduate School, have examined the dissertation entitled:

\section{FORAGE PRODUCTION AND DIVERSIFICATION FOR CLIMATE-SMART TROPICAL AND TEMPERATE SILVOPASTURES}

Presented by Ryan H. Dibala, A candidate for the degree of doctor of philosophy, And hereby certify that, in their opinion, it is worthy of acceptance.

Professor Dr. Shibu Jose

Professor Dr. Michael Gold

Professor Dr. Benjamin Knapp

Professor Dr. Robert Kallenbach

Dr. Jefferson Hall 
Dedicado a las comunidades de Pedasí y Los Asientos, Panamá.

Sin sus esfuerzos cotidianos nada hubiera sido posible.

Que los arboles crezcan, las lluvias vengan, y que un medio ambiente sano alimente a todos. 


\section{ACKNOWLEDGEMENTS}

This work would not have been possible without the continued support and motivation of many people. First and foremost, I would like to thank my lead advisor Dr. Shibu Jose, who put his faith and trust in me from the very beginning to work diligently on my own without direct supervision. His guidance, expertise, and patience has been very much appreciated. Dr. Michael Gold regularly made himself available and showed interest in my work, from joining me for coffee to brainstorm research ideas to working with the Center for Agroforestry to support my travel to conferences, Dr. Gold was always present. Many thanks to Dr. Jefferson Hall, who took time out of his busy schedule to mentor and guide me while I was conducting research in Panama. My thanks also go to Drs. Benjamin Knapp and Robert Kallenbach, who continually supported me in this long-term endeavor as committee members.

I am deeply grateful and fortunate for the people, agencies and organizations that helped financially support my research. Thanks to the U.S. Borlaug Global Food Security Fellowship, USDA ARS, the Dorris D. and Christine M. Brown Graduate Research Fellowship, and the John D. Bies International Travel Scholarship. Without this funding, the planting of nearly 1700 trees and shrubs on degraded soils along with the resulting research would not have been possible.

Thank you to my many colleagues at the University of Missouri who contributed their knowledge, time and resources to this work. Thank you to Drs. Jerry van Sambeek, Ranjith Udawatta, John Kabrick, and Michael Stambaugh for lending me their advice and equipment. Thanks to Drs. Mark Ellersiek, Chris Wilke, William Lamberson, and Lada Micheas for their help with statistics. Thanks to Center for Agroforestry colleagues 
Gregory Ormsby Mori for his constant moral support and Caroline Todd, who managed to continue smiling at me despite the mess of paperwork I often presented her. Thanks to everyone at the Horticulture and Agroforestry Research Center (HARC) for their hard work and support even though I could not be present a lot of the time. I could not have completed my research at HARC without the help of Barry Eschenbrenner, Aaron Templemire, Richard "Bo" Young, and Sam Sergent.

Thanks to Esilda Gonzalez, Vernon Scholey, and Nicolás Solís for graciously lending me plots of land on their farms to plant trees, shrubs, and grasses. It would not have been possible to conduct this research without the long-term support of these three individuals. I would like to thank my friend Jaime Madrid who taught me a tremendous amount in the field. Without his knowledge and guidance this project would not have been successful. I also would like to thank the men who worked day in and out with me under the tropical sun and heat. Thanks to Osvaldo Barrio, Euclides "Mula" Mansilla, Heriberto Mansilla, Jaime de Leon, Chino, Manuel Facio, Matt "Dutch" Silfer, and Jonas Hinz for helping me to remember the value of hard work.

I am indebted to the Azuero Earth Project for their continual dedication to collaborating with me on this project. Thanks to Edwina von Gal, Ruth Metzel, and Jairo Batista for believing in the promise of a greener Azuero Peninsula. I am grateful for the collaboration of Jenny Ordoñez at CATIE in Turrialba, Costa Rica, and for her guidance and mentorship along the way. I would also like to thank Ben Turner and Dayana Agudo at the Smithsonian Tropical Research Institute Soils Laboratory for taking their time to provide me with valuable advice. 
At last I will thank my family and friends, who know how passionate I am about reforestation and conservation and have always unconditionally supported me in this endeavor. A special thanks to Angie Kennedy, my better half, who has been my biggest source of strength and support, despite having to endure my occasional dissertationinduced tantrums. To all my family and friends, I am immensely fortunate and grateful for everything you have done for me to get me to where I am today. 


\section{TABLE OF CONTENTS}

Acknowledgements.............................................................

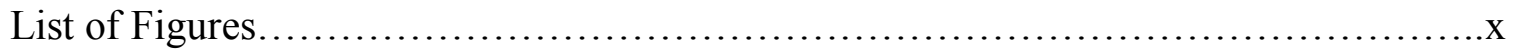

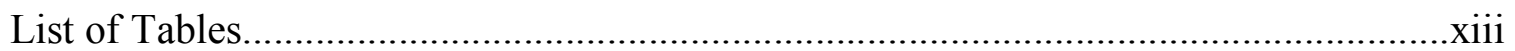

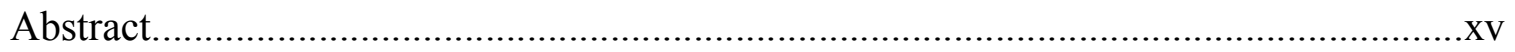

Chapter

1. Silvopasture, Food Provisioning or Depletion? How Raising Livestock with Trees Enhances Food Security in a Changing Climate........................................

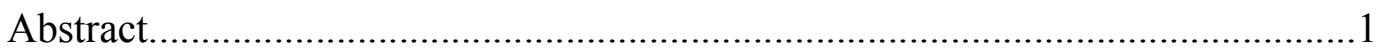

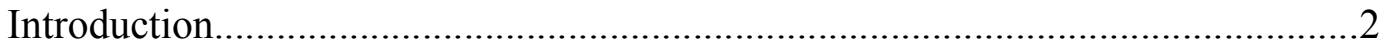

The Food-Climate Crisis..........................................................2

Sustainable Livestock Production.............................................. 3

Silvopasture: A Contribution to Food Security......................................4

Forage Dry Matter Production.......................................................4

Forage Nutritive Value.......................................................8

Tree Fodder Production and Nutritive Value................................9

Tree Fruit Production.................................................................13

Animal Performance............................................................. 15

Animal Welfare.................................................................21

Habitat for Pollinators..............................................................24

Silvopasture in the Future ................................................................25

Rationale for the Current Study.....................................................28

2. Tree Density Effects on Soil, Dry Matter Production and Nutritive Value of Understory Megathyrsus maximus in a Seasonally Dry Tropical Silvopasture Tropics in

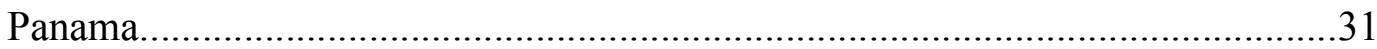

Abstract..................................................... 31

Introduction......................................................... 


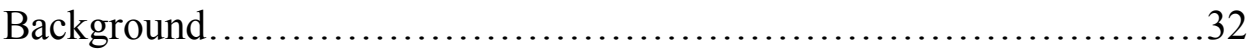

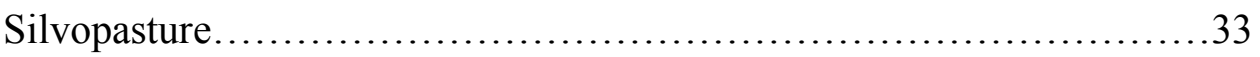

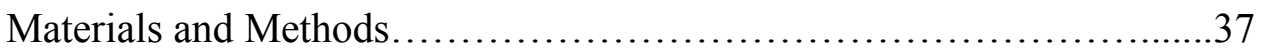

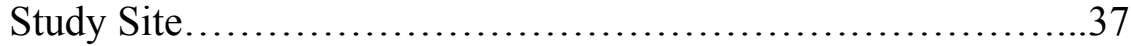

Experimental Design........................................41

Understory Light Environment.................................42

Soil Properties............................................. 43

Soil Volumetric Water Content................................44

Grass Dry Matter Production and Nutritive Value................45

Data Analysis...................................................46

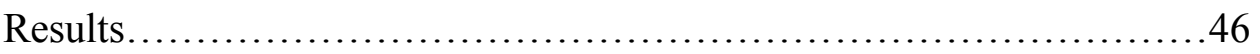

Forage Dry Matter Production...................................46

Forage Nutritive Value.....................................47

Understory Light Environment.................................52

Soil Properties..............................................53

Soil Volumetric Water Content..............................55

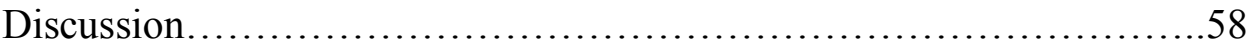

Forage Dry Matter Production................................58

Forage Nutritive Value.....................................61

Soil Properties................................................. 63

Soil Volumetric Water Content................................67

Conclusion............................................................ 71

3. Can Fodder Shrubs Act as Fertilizer? The Neighborhood Effect of Shrubs on Soil Fertility, Pasture Production, and Albizia saman Growth and Survival in Simulated Silvopastures in Panama.......................................................................74

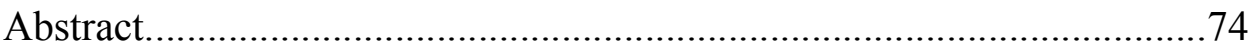

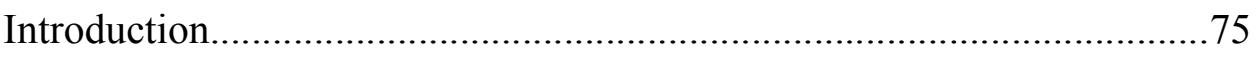

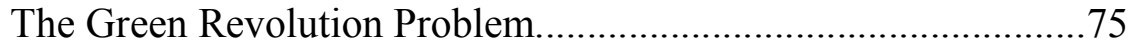

Integrating Fertilizer Trees into Prevailing Land-Use Strategies..76 


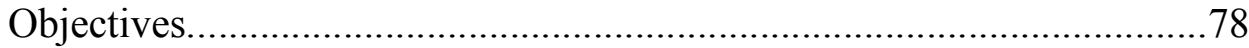

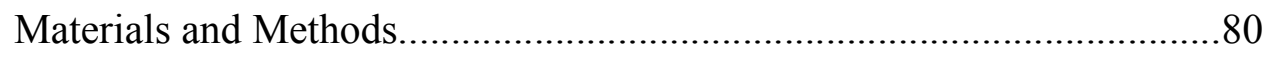

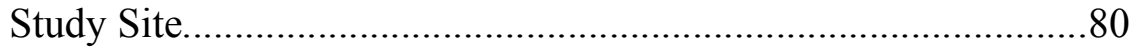

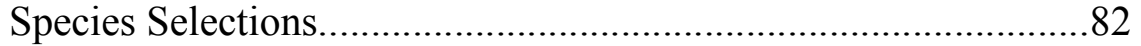

Planting and Plot Maintenance.........................................................85

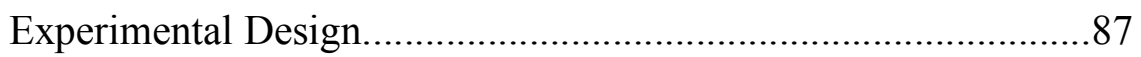

Physical and Chemical Soil Properties............................................8

Bulk Density and Texture.................................................... 88

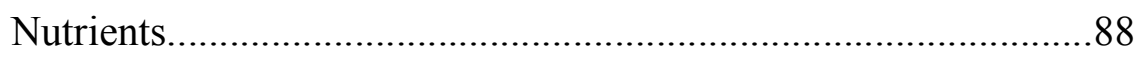

Soil Volumetric Water Content..............................................................90

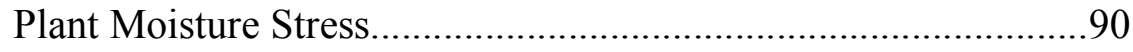

Grass and Fodder Shrub Dry Matter Production............................91

Grass Dry Matter Production.............................................91

Shrub Dry Matter Production...............................................92

Growth and Survival of Saplings...................................................92

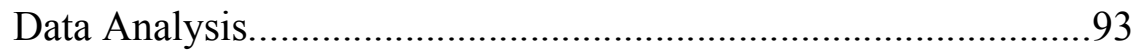

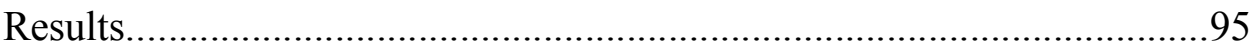

Soil Physical and Chemical Properties..........................................95

Soil Volumetric Water Content...................................................106

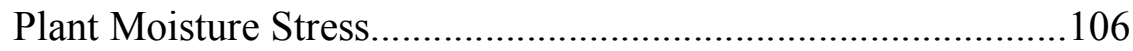

Grass Dry Matter Production......................................................109

Shrub Dry Matter Production.......................................................110

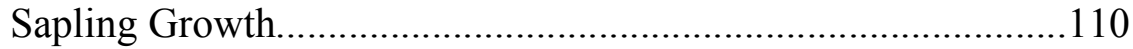

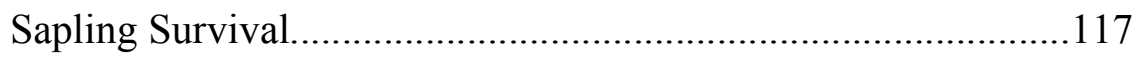

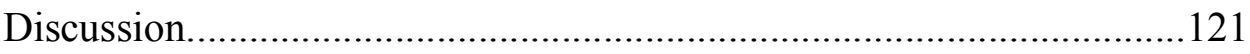

Soil Physical and Chemical Properties........................................121

Soil Volumetric Water Content....................................................125

Plant Moisture Stress..................................................................126

Grass Dry Matter Production.......................................................126

Sapling Growth.....................................................................130 


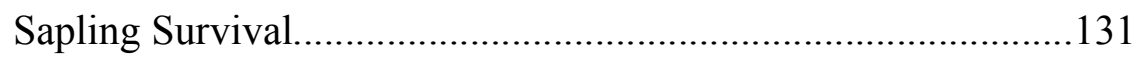

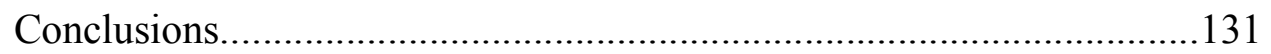

Management Recommendations..................................................133

4. Initial Performance of Red Mulberry (Morus rubra L.) Under a Light Gradient: An Overlooked Alternative Livestock Forage?......................................................135

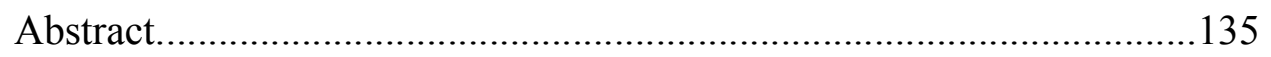

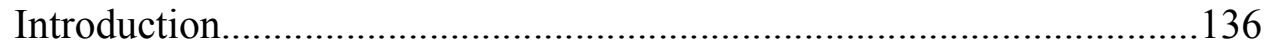

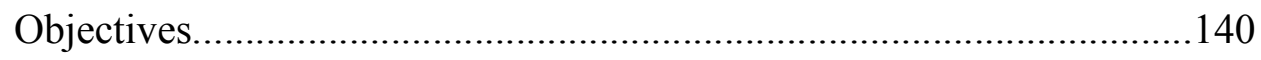

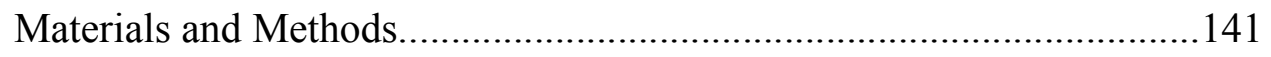

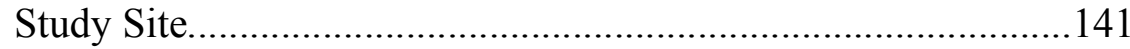

Experimental Design................................................................... 141

Understory Light Environment....................................................146

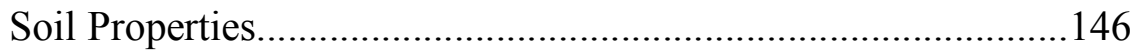

Growth, Specific Leaf Area, and Dry Matter Yield......................147

Nutritive Value............................................................................150

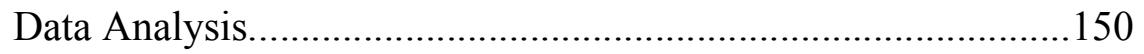

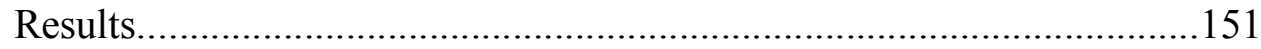

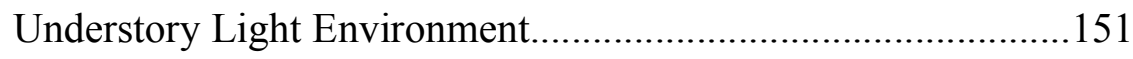

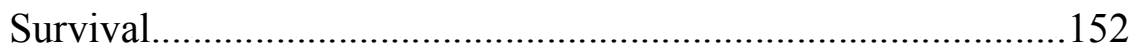

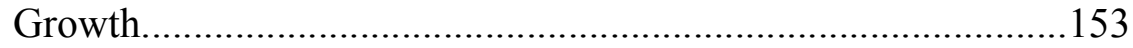

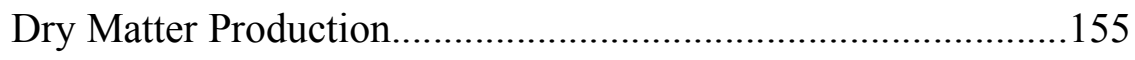

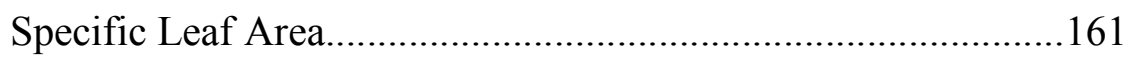

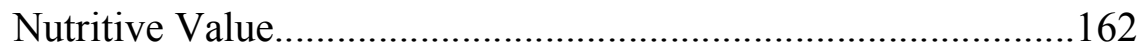

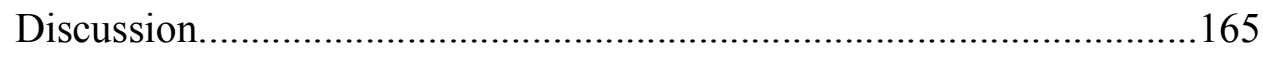

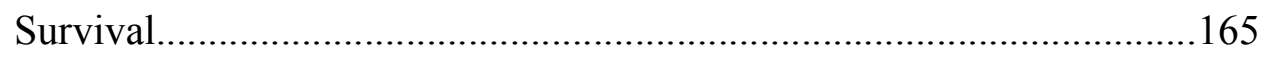

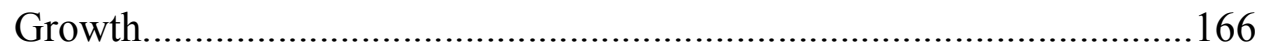

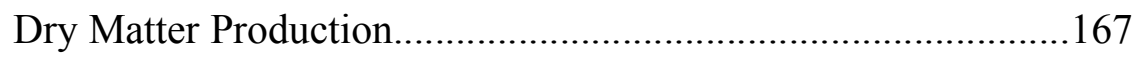

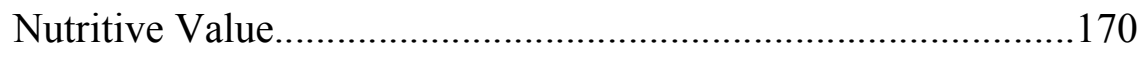

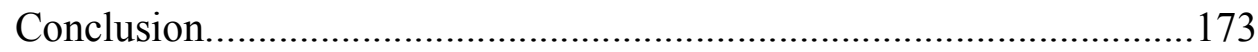

Management Recommendations.................................................173 


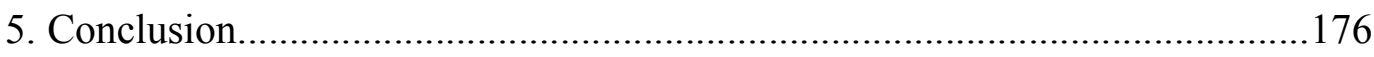

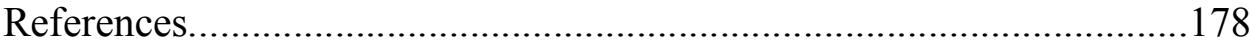

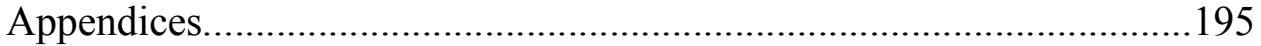

Appendix A: Protocol for Hemispherical Photography.........................196

Appendix B: Survival of T. guayacan Seedlings in August 2016...........199

Appendix C: Images of Research in Ch. 2 ........................................200

Appendix D: Images of Research in Ch. 3.........................................202

Appendix E: Images of Research in Ch. 4.........................................211

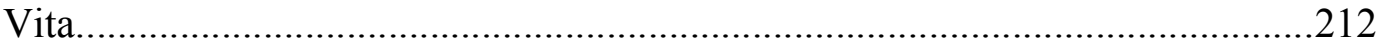




\section{LIST OF FIGURES}

\section{Chapter 1}

Figure 1: Pasture growth rates in traditional and integrated pastures.............. 7

Figure 2: Dry matter yield and stocking rate in silvopasture and monocultures...18

Figure 3: Effects of agroforestry on butterfly diversity on farms in the UK......25

\section{Chapter 2}

Figure 1: Precipitation and mean monthly temperature at Venao in 2016............38

Figure 2: Seasonal differences depicted from the study plantation.....................41

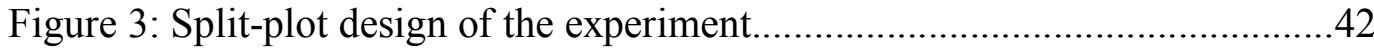

Figure 4: Hemispherical photos used to generate global site factor (GSF)..........43

Figure 5: Grass dry matter (DM) yield for 3 cultivars in O, M, and D during

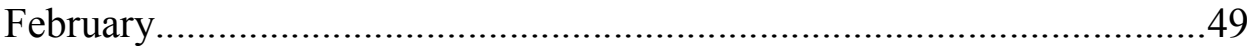

Figure 6: Total grass DM for 4 sampling periods over 2 seasons......................49

Figure 7: Mean GSF within 3 treatments for both seasons.................................52

Figure 8: Bulk density at 3 depths in O, M, and D for 2015 and $2017 \ldots \ldots \ldots \ldots \ldots . . . .54$

Figure 9: Yearly soil volumetric water content (VWC) in O, M, and D at four depths

\section{Chapter 3}

Figure 1: Locations of the three study sites on the Azuero Peninsula...................81

Figure 2: Precipitation and mean monthly temperature at Venao in $2016 \ldots \ldots \ldots \ldots . . .82$

Figure 3: The four plant components of the three-strata silvopasture system.......86

Figure 4: Planting seedlings and stem cuttings in the 2015 wet season................87

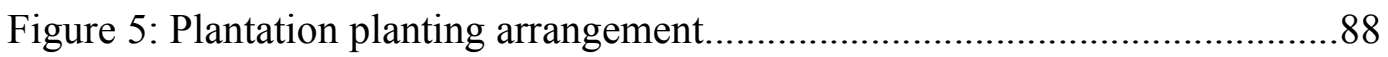

Figure 6: Changes in soil organic matter (SOM) for years and treatments...........99

Figure 7: Relationship between SOM and total C for years and treatments........101

Figure 8: Differences between treatments LSMs for Mehlich-3 plant available

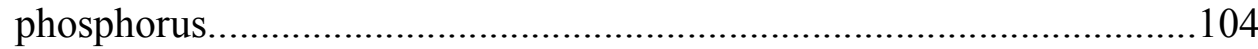

Figure 9: Yearly soil VWC for four depths in all eight planting regimes...........107 
Figure 10: Yearly mean leaf water potential for A. saman saplings....................108

Figure 11: Total grass dry matter for four sampling periods over two seasons...109

Figure 12: Species contributions to total annual dry DM yield.........................113

Figure 13: Mean height of $A$. saman target saplings over four periods................114

Figure 14: An example of one $A$. saman sapling over three $\mathrm{m}$ tall in Pedasi......117

Figure 15: Mean monthly height increment of saplings over four periods..........118

Figure 16: Mean monthly diameter increment of saplings over four periods......119

Figure 17: Greenness of fodder shrubs and grasses in the dry season.................125

Figure 18: T. diversifolia and the lack of Massai grasses associated with it.......129

\section{Chapter 4}

Figure 1: RCB design of the experiment under four overstory tree densities.....142

Figure 2: Precipitation and mean monthly temperature at HARC, 2016-2018...144

Figure 3: Planting arrangement of the M. rubra seedlings...............................145

Figure 4: Height and root collar diameter measurements.................................149

Figure 5: Mean height of target trees growing under four tree densities over 28

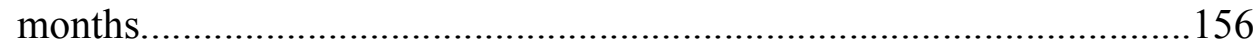

Figure 6: Mean absolute growth rate (AGR) for height, 2017-2018.................158

Figure 7: Mean root collar diameter of target trees..........................................158

Figure 8: Mean AGR for diameter, 2017-2018............................................159

Figure 9: Mean crown width of target trees.....................................................159

Figure 10: Mean specific leaf area measured from 40 leaves per plot.................161

\section{Appendix B}

Figure 1: Relative survival of T. guayacan and A. saman seedlings.

\section{Appendix C}

Figure 1: Three M. maximus cultivars growing in the understory of treatment

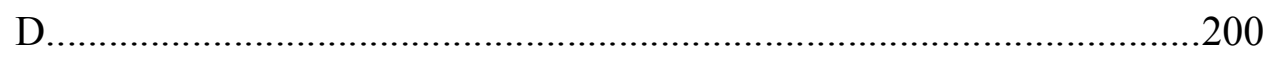

Figure 2: The $0.5 \times 0.5 \mathrm{~m}$ grid that was used to sample pasture grasses.............201

Figure 3: Recording data during the assessment of grass DM production..........201 


\section{Appendix D}

Figure 1: Field assistant Dutch Silfer helps to demarcate treatment plots...........202

Figure 2: Hauling seedlings via horseback to the planting site.........................202

Figure 3: Treatment plots at Calabacito during the dry season.........................203

Figure 4: Treatment plots at Pedasi during the rainy season............................204

Figure 5: Treatment plots at Los Asientos during the rainy season.....................205

Figure 6: Getting ready to assess sapling moisture stress with pressure

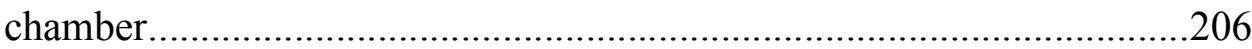

Figure 7: Measuring soil VWC at Los Asientos during the dry season...............207

Figure 8: Central A. saman surrounded by L. leucocephala and

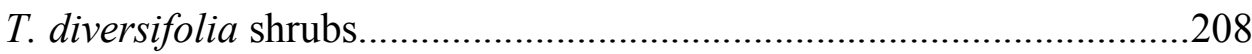

Figure 9: A. saman saplings at Los Asientos during the dry season...................209

Figure 10: Measuring sapling height at Pedasi during the wet season...............210

\section{Appendix E}

Figure 1: M. rubra seedlings planted and protected by plastic tubing...............211

Figure 2: Measuring the root collar diameter of a M. rubra seedling at 


\section{LIST OF TABLES}

\section{Chapter 1}

Table 1: Forage availability, refusal, and utilization efficiency in Mexico...........11

Table 2: Performance of cow-calf pairs in traditional and integrated pastures.....16

Table 3: Average daily gain per area in silvopastures and monocultures..............17

Table 4: Production parameters of conventional and ISS farming systems..........20

Chapter 2

Table 1: Soil texture from three sampling depths within each of three

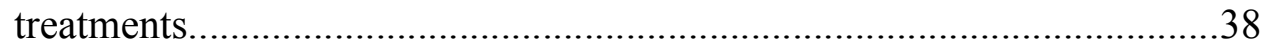

Table 2: Tree species representation in the 2005 plantation at the study site........39

Table 3: Overstory composition in a mixed native tree plantation.......................40

Table 4: DM yield for 3 grass cultivars under O, M, and D for two seasons........48

Table 5: Nutritive value for 3 cultivars under $\mathrm{O}, \mathrm{M}$, and $\mathrm{D}$ for two seasons.........51

Table 6: Physical and chemical soil properties from 3 treatments, 2015 and

2017 .56

\section{Chapter 3}

Table 1: Soil texture from three sampling depths within each of eight treatments

Table 2: Bulk density at three depths for all eight treatments, 2015 and 2017

Table 3: Soil fertility parameters from 2015 and 2017.

Table 4: Pre- and post-trial SOM, TC, TN, C:N, and Mehlich-3

phosphorus.

Table 5: Pre- and post-trial ammonium and nitrate 105

Table 6: Species contributions to total mean annual DM yield for eight treatments.

Table 7: Least square means (LSM) for total DM yield 112

Table 8: A. saman final height and diameter. 
Table 9: ANOVA table for the mixed model with responses height and diameter. 116

Table 10: Percent of $A$. saman saplings surviving within the eight treatments. 120

\section{Chapter 4}

Table 1: Chemical soil properties for samples collected in May of 2018............143

Table 2: Precipitation and mean monthly temperature at HARC.........................144

Table 3: Overstory composition at four planting densities....................................145

Table 4: Global site factor values for each treatment and season.........................152

Table 5: Percent of M. rubra seedlings surviving during each measurement

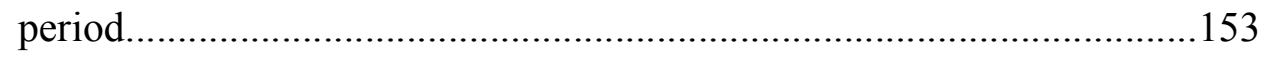

Table 6: LSM estimates for height, diameter, and crown width...........................157

Table 7: LSM estimates obtained for mean DM yield of M. rubra .......................160

Table 8: LSM estimates for M. rubra leaf nutritive value parameters..................163

Table 9: LSM estimates of major mineral concentration in M. rubra leaves......164 


\title{
FORAGE PRODUCTION AND DIVERSIFICATION FOR CLIMATE-SMART TROPICAL AND TEMPERATE SILVOPASTURES
}

\author{
Ryan H. Dibala
}

\author{
Dr. Shibu Jose, Dissertation Supervisor
}

\section{ABSTRACT}

Climate change creates much uncertainty for the future of animal agriculture, particularly due to an increase in summer droughts that result in the loss of range productivity. Silvopasture, the intentional integration of livestock, trees, and pasture on the same unit of land, is a promising option to diversify forage resources, compensate for losses caused by droughts during the summer forage gap, and in some cases, even increase agricultural production while maximizing conservation benefits. We examined three distinct silvopastures, two in the country of Panama and one in the state of Missouri, to better understand how the integration of woody perennial trees and shrubs affects forage productivity, availability, and nutritional value, particularly during the driest months. In Panama, we studied both recently established and mature silvopastures with the objective of assessing soil physical and chemical properties, plant water availability, and pasture dry matter production in different successional stages. In the mature silvopasture, we found that annual grass accumulation was greatest in open pastures, but was highest in silvopastures with moderately-spaced trees $\left(\sim 500\right.$ trees $\left.\mathrm{ha}^{-1}\right)$ early in the dry season. In the recently established silvopasture, the simultaneous growth of grasses, trees, and fertilizer shrubs resulted in significant increases in soil fertility and marginally significant increases in grass production in plots that included the shrub Leucaena leucocephala. Further, cumulative forage production in plots with shrubs provided on average $9.66 \%$ more forage than plots without shrubs during the dry season. In Missouri, we assessed the feasibility of integrating the potential alternative forage shrub red mulberry (Morus rubra L.) into the understory of an existing silvopasture and found that seedling survival, growth, leaf productivity, and nutritive value could be optimized at an overstory planting density of $\sim 123$ trees ha $^{-1}$. High leaf mineral content and low fiber fractions during the late summer forage slump suggest that this species could serve as an effective supplemental forage to livestock in multi-strata silvopastures during drought conditions. Results of all three studies confirm that silvopasture has both competitive and facilitative influences on forage production, and that facilitative factors may be more prevalent during extreme drought. 


\title{
Chapter 1
}

\section{Silvopasture: How Raising Livestock with Trees Enhances Food Security in a Changing Climate}

\begin{abstract}
Globally, the human population is exploding and is expected to reach 9.1 billion by 2050 , resulting in a rapidly growing demand for animal products and continued natural resource degradation, all of which have profound effects on food security. This chapter draws on examples from across the globe to highlight the many contributions of silvopasture - the intensively managed integration of trees, forages, and livestock - to achieving food security. We focus on the production of forage, meat, and milk in silvopastoral systems as direct indicators of food supply as well as indirect indicators such as thermal stress in livestock, animal health, and habitat provisioning for pollinators. We address the problems of modern animal agriculture and how silvopasture may play a critical role in the sustainable intensification of livestock production systems. We then point out some important research needs and provide a rationale and brief outline for the major objectives of the three studies presented in this dissertation.
\end{abstract}

Key words: Silvopasture, agroforestry, food security, forage production, animal performance, animal welfare 


\section{Introduction}

The Food-Climate Crisis

Agroforestry is often praised for the many environmental benefits it provides, such as carbon sequestration, enhancement of wildlife habitat, and reduction of toxic runoff into waterways. However, there remains an important and often overlooked consequence of the ecosystem services provided by agroforestry: food security. In a time when monocultures and chemicals of conventional agriculture prevail, there is growing concern about the future of food production, particularly in regards to soil loss and degradation, indiscriminate use of agrochemicals and their effects on native plants and pollinators, and the environmental and ethical abuses of industrial animal agriculture. Globally, the human population is rapidly increasing and is expected to reach 9.8 billion by 2050 , urbanization is increasing, and incomes are rising. This has resulted in a rapidly growing demand for animal products and continued natural resource degradation, all of which have profound effects on food security (Delgado et al. 1999).

Although global grain production has more than doubled and global meat production has more than tripled over the last half-century (FAOSTAT 2010), food yield may need to increase by $50 \%$ or more in the next half century to keep up with demands (Godfray et al. 2010). Projected demands of meat and milk production are expected to grow at rates of 2.8 and 3.2\% annually up to 2020 (Delgado et al. 1999). All the while, food producers are experiencing greater competition for land, water, and energy. Climate change is exacerbating consequences for animal production through its effects on forage and range productivity and heat related stress on the animal. Under climate change scenarios, water will become the main limiting factor to all livestock systems (Steinfeld 
et al. 2006; de Fraiture et al. 2010) and extended droughts will become the norm. In the face of climate change, producing more food for a growing population while diminishing poverty and hunger is a daunting task, but a challenge that must be heeded. An even greater challenge is not only to increase productivity, but to do so while treading more lightly on the land (Cribb 2010).

Sustainable Livestock Production

Many decades of research have demonstrated that livestock management is critical for maintaining healthy pastures and optimal productivity (Gerrish 2004; Rayburn 2007). In 1959, farmer and scientist André Voisin coined the term Rational Grazing (Voison 1988), where he described the basic guidelines necessary for good grazing management: short periods of occupation followed by an ample recovery period. More recently, authors have built on these management guidelines with the introduction of terms such as prescribed grazing (USDA - NRCS 2010), management intensive grazing (MiG) (Gerrish 2004), holistic planned grazing (HPG), and mob grazing (Savory and Butterfield 2016). All of these terms apply the same key grazing principles proposed by Voisin, ultimately favoring important pasture species, improving soil health, and increasing forage productivity and nutritional quality (Flack 2016).

These sustainable livestock production methods can be implemented in open pasture or alternatively under dispersed tree cover in a silvopastoral setting. Silvopasture is an agroforestry practice where trees and livestock are combined with improved pasture plants and managed intensively, effectively integrating intensive animal husbandry, silviculture, and forage agronomy practices (Sharrow et al. 2009). The simultaneous 
production of timber and livestock can increase the diversity of on-farm products, improve land-use efficiency, and provide better welfare for animals (Murgueitio et al. 2011; Calle et al. 2012b; Broom et al. 2013). Despite numerous accounts of silvopasture's ability to strike optimal balance between production and conservation (Ibrahim et al. 2010; Galindo et al. 2013; Jose et al. 2017), many producers remain skeptical, arguing that forage and animal productivity is too greatly reduced under tree cover (Fischer and Vasseur 2002; Garen et al. 2011).

In this paper, we review a number of studies from various regions of the world that highlight silvopasture's contribution to achieving food security. We focus on the production of forage, meat, and milk in silvopastoral systems as direct indicators of food supply as well as indirect indicators such as thermal stress in livestock, animal health, and habitat provisioning for pollinators. We conclude by addressing some of the problems of modern animal agriculture, why food security depends on it, and how silvopasture may play a critical role in the sustainable intensification of livestock production systems.

\section{Silvopasture: A Contribution to Food Security}

Forage Dry Matter Production

It is well-established that trees have both competitive (negative) and facilitative (positive) effects on other organisms around them (Jose et al. 2004; Jose et al. 2019). Canopy solar interception results in lower light transmittance, decreasing the photosynthetic rate of understory vegetation. Trees have been shown to compete vigorously for water and nutrients and can even emit allelopathic chemicals that impede the growth of surrounding vegetation. However, canopy interception can also provide 
protection from desiccating winds, reduce soil surface temperature and soil evapotranspiration (Belsky et al. 1989; Belesky 2005), which can increase overall soil moisture content (Vetaas 1992). Some trees can fix atmospheric nitrogen and provide up to $650 \mathrm{~kg} \mathrm{~N} \mathrm{yr}^{-1}$, more than enough to fulfill crop $\mathrm{N}$ needs for sustained yield (Nygren et al. 2012). Leaf litter under trees has been shown to improve the physical properties of the surface soil, increasing soil nutrients and organic matter (Belsky 1994). As a result, the content of carbon, phosphorus, and nitrogen has been shown to gradually decline as a function from the distance of the trunk, resulting in significantly lower levels in the open ground than in sub-canopy soil (Belsky et al. 1989; Tiedemann and Klemmedson 2008).

Elevated nutrient levels can improve the forage quality of sub-canopy grasses, attracting grazers that return nutrients to the soil. This, combined with the trapping of wind and water-borne sediments by trees can contribute to an 'island of fertility' effect (Belsky et al. 1989; Dohn et al. 2013). Trees roots can also decrease the bulk density of the soil, creating the macro-porosity favorable to the infiltration of water, increasing water-holding capacity (Malmer et al. 2010). These benefits, combined with the selection of appropriate tree and forage species, can sometimes result in increased levels of productivity when compared with grass monocultures.

Tree canopy effects on the growth and nutritive value of understory forages depend on many factors, including forage type, local climate and topography, season, soil fertility and structure, and amount of photosynthetically active radiation (PAR). It is well known that shading has a more detrimental effect on warm-season (C4) grasses than it does on cool-season (C3) grasses (Kephart and Buxton 1993; Lin et al. 1998; Buergler et al. 2005). This is because the physiology of $\mathrm{C} 4$ grasses allows for greater biomass 
accumulation per unit of photosynthetically active radiation (PAR) - or radiation use efficiency - than does the physiology of C3 species. The amount of rainfall appears to be important in determining forage production under shade. In xeric environments where water is the limiting factor, growth and development of many herbaceous species are facilitated by tree canopies through the improvement in moisture regimes (Joffre and Serge 1993), soil nutrients, and organic matter (Kellman 1979)). Several studies have demonstrated that under certain conditions, moderate shading can provide the optimal environment for grass growth and quality (Belsky 1994; Ibrahim et al. 2007; DeBruyne et al. 2011; Orefice et al. 2016). Hernández and Guenni (2008) concluded that M. maximus grasses benefited from a compensatory effect from trees that increased soil humidity and improved total forage biomass. Andrade et al. (2004) found that M. maximus var. Massai grass growing under artificial shade reached its highest dry matter accumulation rate under 30\% shade cover in both the rainy and dry seasons. Moustakas et al. (2013) demonstrated that tree effects on grass biomass across a precipitation gradient in a subtropical savanna were facilitative in drier sites, with greater grass biomass observed beneath tree canopies than outside.

Conversely, many studies in temperate environments with more rainfall have shown that canopy coverage either maintains (DeBruyne et al. 2011) or reduces the quantity of understory forage produced (Feldhake et al. 2010; Orefice et al. 2016). In a study conducted in Appalachia, Neel and Belesky (2015) showed that hardwood silvopasture DM production was $60-70 \%$ that of open pasture in the spring and equal to only $40-60 \%$ of it in summer. Studying an alder and willow silvopasture in New Zealand, 
Devkota and colleagues (2001) concluded that a 40 - 50\% canopy closure would maintain pasture production at approximately two-thirds of that in unshaded pasture.

However, research in both temperate and tropical environments has suggested that silvopasture may extend forage longevity and provide more forage than conventional pastures during certain times of the year. Kallenbach (2009) compared the growth of cool season grasses in traditional open pastures to that of integrated pastures where silvopasture was used on only $25 \%$ of the total land area. Forage growth on integrated pastures outperformed that of traditional pastures early in the spring, mid-summer, and late-fall, all times when cool season grasses likely benefit from more moderate micro-

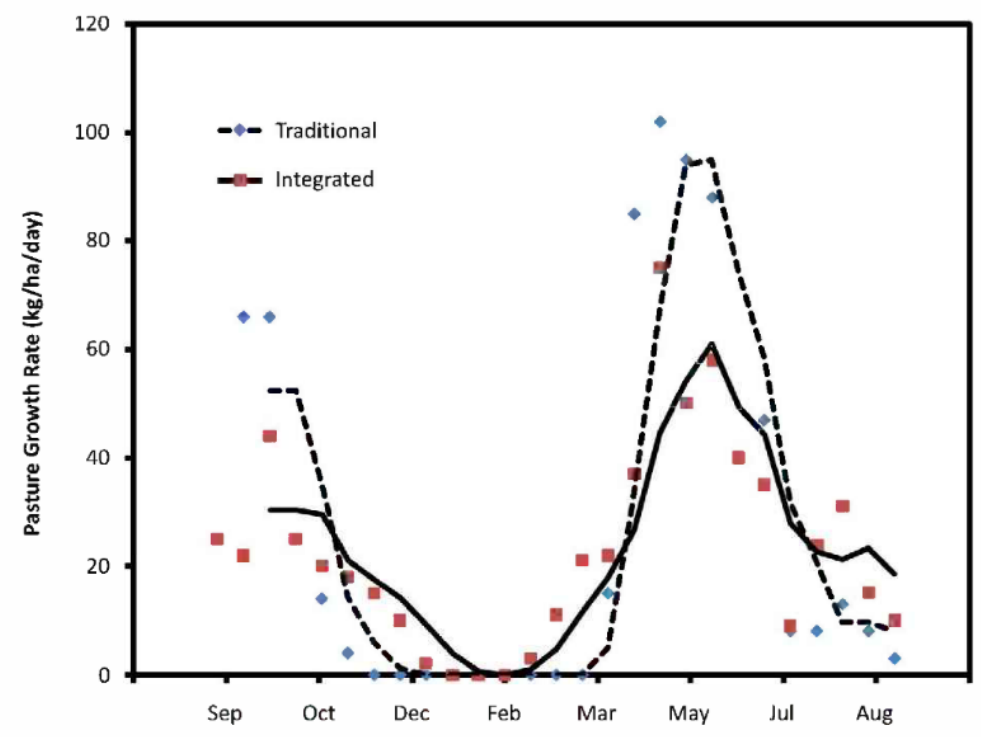

Fig. 1 Pasture growth rates in traditional (open) and integrated (25\% of land area under silvopasture) pasture systems at the Horticulture and Agroforestry Research Center near New Franklin, MO. Source: (Kallenbach 2009)

climates in the understory (Fig. 1). Similarly, a study examining the growth of $M$. maximus in the understory of native tree plantations in Panama found that forage dry 
matter (DM) accumulation was greatest under moderate tree coverage early in the dry season but produced more dry matter in open environments throughout the rainy season (Dibala and Jose, in preparation). These studies indicate that producers may achieve maximum gains by integrating silvopastures into larger open pasture operations and using them only during periods of relative scarcity.

Forage Nutritive Value

A large body of research indicates that forage nutritive value may increase when grown under tree canopies (Lin et al. 1998, 2001; Buergler et al. 2006; Feldhake et al. 2010; Neel and Belesky 2017; Orefice et al. 2017; Pang et al. 2019 a and b). Specifically, increases in crude protein $(\mathrm{CP})$ content are commonly observed. This is likely due to adaptive mechanisms and changes in plant physiology such as elongation of the cell wall (Kephart and Buxton 1993) and increases in the specific leaf area and shoot:root ratio (Paciullo et al. 2017). The presence of nitrogen-fixing trees may also indirectly increase crude protein $(\mathrm{CP})$ levels in forages through leaf decomposition, root exudation, and direct nutrient exchange (Sierra and Nygren 2006; Sierra et al. 2007; Jalonen et al. 2009a). Xavier and colleagues (2014) found that nitrogen recycled via the litter pathway in a silvopastoral system exceeded that in a monoculture by $34 \mathrm{~kg} \mathrm{ha}^{-1}$, concluding that the extra $\mathrm{N}$ recycled in the system - along with biological nitrogen fixation - would confer increases in quality and longevity of forage when compared to grass monocultures.

Typically, the structural carbohydrate metrics acid detergent fiber (ADF) and neutral detergent fiber (NDF) are either increased or unaffected by shade for most forage 
species (Ladyman et al. 2003; Kallenbach et al. 2006; Sousa et al. 2010; Paciullo et al. 2011; Neel and Belesky 2015). However, there are a number of studies that report decreasing values with increased levels of shade (Kephart and Buxton 1993; Obispo et al. 2008; Medinilla-Salinas et al. 2013), indicating lower levels of lignification and overall higher digestibility.

It is well known that the nutritive value of a plant changes throughout its different stages of maturity, containing greater contents of total non-structural carbohydrates (TNC) in the early stages of growth and developing larger quantities of lignin and cellulose later in the season. This increase in lignification reduces digestibility and palatability of the plant, resulting in decreased animal intake. Thus, it is important for producers to manage livestock dynamically in response to temporal changes in both the quantity and quality of forages.

Tree Fodder Production and Nutritive Value

One way producers can respond to these changes is to rely on trees and shrubs to provide alternative and highly nutritious forage sources during critical periods. In the tropics, forage shrubs (also known as fodder shrubs) can be a strategic resource for farmers during the worst drought periods that often occur during the dry season. Some forage shrubs retain green foliage amidst even the harshest droughts due to their deep root systems that have specialized access to the water table. As the dry season progresses, forage shrubs have been shown to lose nutritive value, digestibility, and palatability at a slower rate than herbaceous forages (Talamuci and Pardini 1999), providing relatively 
high quality supplemental forage to both ruminants and non-ruminants during times of scarcity.

A widely touted model of silvopasture that includes the use of native and nonnative trees, shrubs, and herbaceous forages is known as intensive silvopasture. Intensive silvopastoral systems (ISS) include the planting of timber trees that are intercropped with high density $\left(\sim 10,000\right.$ plants ha $\left.{ }^{-1}\right)$ plantings of fodder shrubs and highly productive pasture grasses in a system that can be directly grazed by livestock (Murgueitio et al. 2011). Shrubs are periodically coppiced to encourage low, dense growth of the foliage. Cattle are provided permanent supplies of drinking water and rotated periodically with the use of electric fences to prevent overgrazing and to allow time for pastures to recover. ISS first began in Australia more than 40 years ago, but it is now becoming the technology of choice in Colombian and regional livestock sectors because they can help reduce the seasonality of plant and animal production, and therefore help to mitigate and adapt to climate change (Cardona et al. 2013).

There is compelling evidence that demonstrates its efficacy. An ISS using the shrubs Leucaena leucocephala and Gliricidia sepium combined with the grass $M$. maximum in the humid tropics of West Africa produced of over 20 tons of DM ha ${ }^{-1}$ of mixed tree-grass fodder (Atta-Krah and Reynolds 1989). Bacab-Pérez and SolorioSánchez (2011) compared forage availability and voluntary intake on two ISS ranches with a conventional ranch in Michoacán, Mexico, and found that the available forage in both ISS ranches was at least 2.6 times higher than that in the traditional ranch $(17,290$ and 18,851 versus $6,636 \mathrm{~kg} \mathrm{DM} \mathrm{yr}^{-1}$ ). Furthermore, only $9 \%$ of the available Leucaena forage was rejected by cattle on both ISS farms (Table 1). Shelton and Dalzell (2007) 
reported that Leucaena-grass pastures are the most productive, profitable, and sustainable beef production systems in northern Australia.

Table 1 Forage availability, refusal, and utilization efficiency at three farms in Michoacán, Mexico.

\begin{tabular}{|c|c|c|c|c|c|}
\hline Farm & Forage & $\begin{array}{c}\text { Edible forage } \\
\text { (kg DM/Ha) }\end{array}$ & $\begin{array}{c}\text { Rejection } \\
\text { (kg DM/Ha) }\end{array}$ & Use (kg DM/Ha) & Use (\%) \\
\hline \multirow{3}{*}{ Los Huarinches } & L. leucocephala & 8,386 & 826 & 7,560 & 91 \\
\hline & $M^{\text {ximum }}$ & 8,904 & 4,655 & 4,249 & 48 \\
\hline & Iotal & 17,290 & 5,481 & 11,809 & 68 \\
\hline \multirow{3}{*}{ El Aviador } & L. leucocephala & 9,156 & 826 & 8,330 & 91 \\
\hline & - -ximum & 9,695 & 3,542 & 6,153 & 63 \\
\hline & $M_{\text {tal }}$ & 18,851 & 4,368 & 14,483 & 77 \\
\hline Conventional & C. plectostachyus & 6,636 & 2,660 & 3,976 & 60 \\
\hline
\end{tabular}

Source: Cardona et al. (2013); Originally modified from Bacab-Peréz and Solorio-Sánchez (2011)

The use of woody trees and shrubs for livestock fodder in temperate regions has been limited primarily due to a relatively limited plant selection and existing cultural and behavioral norms. Temperate regions lack the diversity of nutritious, nitrogen fixing woody plants capable of coppicing that exist in the tropics and trees that produce palatable fodder only do so during the growing season when highly preferred herbaceous forage is available, unless compromised by extreme weather. Cultural norms such as stockpiling and hay-baling are used instead of the cut-and-carry systems more commonplace in the tropics. However, researchers in temperate regions have explored the production and intake of densely planted forage shrubs and some species have shown particular promise. In North Carolina, black locust (Robinia psuedoacacia) fodder banks were highly preferred by meat goats with a mean dry herbage yield of 3,213 $\mathrm{kg} \mathrm{ha}^{-1}$ when 
planted on a $50 \mathrm{~cm}$ spacing and coppiced at $50 \mathrm{~cm}$ (Addlestone et al. 1999). In New Zealand, full access to willow (Salix spp.) fodder banks was beneficial for ewe reproductive rates (Pitta et al. 2005). Other promising species for temperate intensive silvopastures include Paulownia (Mueller et al. 2001) and mulberry (Morus spp.) (Sánchez 2000).

Silvopastoral systems containing forage shrubs are effective at improving animal production because tree foliage is often of higher nutritional quality than grasses (Mueller et al. 2001). Sosa Rubio and others (2004) analyzed the nutritive value of 30 perennial woody species and found that $70 \%$ of them contained CP values of $12 \%$ or more. Studies in Greece have shown that the most common native woody plants have higher CP than grasses and forbs during the summer (Papachristou and Papanastasis 1994). In the case of tropical legumes, even the seeds are browsed, which can provide nutrients in excess of that required for digestion and metabolism, potentially correcting nutritional deficiencies in mature roughage (Aganga and Tshwenyane 2003).

The overall nutritive value of woody perennial forage often can be hindered by the presence of anti-nutritional compounds that have the ability to severely restrict nutrient utilization (Papanastasis et al. 2008). Secondary compounds such as condensed tannins, alkaloids, saponins, and oxalates are known to occur in many woody perennials and can have detrimental effects to the animal if consumed in high quantities. However, diets containing herbaceous forage with a high level of digestible CP have been shown to counteract the negative effects of tannins (Yiakoulaki 1995). Furthermore, tannins in low to moderate concentrations (20-40 $\left.\mathrm{g} \mathrm{kg}^{-1} \mathrm{DM}\right)$ can induce beneficial effects, which are associated with suppression of bloat in ruminants (Jones et al. 1973). 
Tree Fruit Production

The more obvious food product of perennial trees and shrubs is fruit. In 1929, author J. Russell Smith exposed the masses to the agricultural wealth of trees in his seminal work Tree Crops: A Permanent Agriculture (Smith 1950). In this masterpiece, Smith expounds on the overlooked abundance of food for both humans and animals produced by woody perennials. He describes the fruiting patterns and yields of common trees like oak (Quercus spp.), hickory and pecan (Carya spp.), walnut (Juglans spp.), chestnut (Castanea spp.), persimmon (Diospyros spp.), carob (Ceratonia siliqua), mulberry (Morus spp.), and honeylocust (Gliditsia triacanthos). A litany of anecdotes from producers pepper the pages of this book, with statements like:

"I never weighed my pigs at the beginning and close of the mulberry season, but I think I can safely say that a pig weighing 100 pounds at the start would weight 200 pounds at the close" and,

"I let the cattle pick them (honeylocust pods) up where they can; and where they cannot graze, the beans are gathered and fed to them. My herd of heifers get a great part of their winter pasture from the honeylocust pods."

Since then, many accounts like these have been corroborated with empirical evidence. Gold and Hanover (1993) noted that the edible seedpods from honeylocust trees can serve as supplemental feed for livestock over several months in autumn and winter when cool-season grass production is limited or negligible. In Virginia, whole- 
ground honeylocust seedpods from the 'Millwood' cultivar had a nutritional profile comparable to that of ground whole-ear dent corn (Zea mays L.) or oat (Avena sativa L.) grain (Johnson et al. 2013). In that same study, mean DM yields of pod-bearing trees were $15.8,4.8$, and $14.7 \mathrm{~kg} \mathrm{tree}^{-1}$ in 2008,2009 , and 2010, respectively. In good years, a honeylocust crop can easily exceed $66 \mathrm{~kg}$ of cleaned seed per tree (Gold and Hanover 1993).

In the Mediterranean oak woodland known as the dehesa, Iberian pigs are raised extensively on acorns and grass during a two-month fattening period that coincides with the fruiting period of surrounding holm oak (Quercus ilex Lam. spp. ballota) and cork oak (Quercus ilex L.). In the managed dehesa, where mean tree density ranges between 30 and 50 trees ha ${ }^{-1}$, the productivity of acorns is reported to be ten times higher than a dense Quercus ilex forest (Pulido 1999; Pulido et al. 2001). Although extremely variable, mean acorn yield was estimated to be $300-700 \mathrm{~kg} \mathrm{ha}^{-1}$; with yields of $8-14 \mathrm{~kg}$ tree-1 for Q. ilex and 5-10 $\mathrm{kg}$ tree $^{-1}$ for $Q$. suber (Rodríguez-Estévez et al. 2007). Individual pigs can consume $7-10 \mathrm{~kg}$ of acorns day ${ }^{-1}$, and generally will increase their weight from 100 to $160 \mathrm{~kg}$ (Nieto et al. 2002).

In Southeast Asia, livestock is raised under commercially important tree crops like coconut (Cocos nucifera), palm oil (Elaeis guineensis), and rubber (Hevea brasiliensis) on an estimated 210 million ha (Alexandratos 1995). The establishment of mixed pastures under coconuts in Sri Lanka resulted in increases of $17 \%$ and $11 \%$, in nut and copra yields, respectively (Liyanage et al. 1993). Moreover, the nutrients from $73 \mathrm{~kg}$ of fresh manure and 301 of urine palm ${ }^{-1}$ year $^{-1}$ reduced the cost of fertilizing the coconuts by $69 \%$ (Devendra and Ibrahim 1999). Livestock can also help reduce the cost of weed 
maintenance, as is the case with Chee and Faiz (1991), who reported a reduction of 20$40 \%$ in weeding costs due to regular grazing by cattle.

\section{Animal Performance}

Several important measurements of silvopasture's sustainable contribution to food security are livestock average daily gain (ADG), conception and reproductive rate, and stocking rate (animal units $\mathrm{AU} \mathrm{ha}^{-1}$ ). An increase in any of these metrics can translate into income generation for ranchers. Historically, most studies on silvopastoral systems in temperate regions have demonstrated either decreased or equal animal performance when compared to open pastures (Teklehaimanot et al. 2002; Kallenbach et al. 2006, 2010; Sharrow et al. 2009; Neel, J.P.S. and Belesky 2015). More recently, Pent and Fike (2018) compared average daily gains (ADGs) of lambs in black walnut (J. nigra) and honeylocust (G. triacanthos) silvopastures with open pasture of stockpiled tall fescue (Schedonorous arundinaceus) during the winter in Virginia. During the first three weeks of the trial, lambs did not consume honeylocust pods due to naivety, but after the fourth week, consumption of pods was so high that lamb ADG was significantly greater than that in plots without honeylocust. Future study is needed to determine whether honeylocust supports even greater lamb weight gains when there has been previous exposure to pods and higher quality herbaceous forages are available (Pent and Fike 2018). In a study previously described evaluating integrated silvopastures, Kallenbach (2009) reported that cows in silvopastures lost approximately $10 \%$ less weight over winter, reducing the need for supplementation by about $12 \%$. Additionally, cows that 
gave birth in the integrated treatment were $12 \%$ less likely to experience calving difficulty (Table 2).

Table 2 Performance of cow-calf pairs in a traditional (open) pasture system compared to those in an integrated system where both open and silvopastures were used. Source: (Kallenbach 2009)

\begin{tabular}{lllll}
\hline Treatment & $\begin{array}{l}\text { Cow body } \\
\text { loss in winter }\end{array}$ & weight & Calving difficulty & Calf weaning weight \\
\hline \multirow{3}{*}{ Traditional } & $(\mathrm{kg})$ & $\%$ & $(\mathrm{~kg})$ \\
Integrated & 93 & 15 & 270 \\
P value & 0.02 & 3 & 295 \\
\hline
\end{tabular}

More examples of silvopasture's positive influence on animal performance can be found from the tropics. A silvopastoral system in Brazil including signal grass (Brachiaria decumbens) and the leguminous shrubs G. sepium and Mimosa caesalpiniifolia planted at a density of 2500 plants ha ${ }^{-1}$ produced similar livestock production per unit land area compared with signal grass in monoculture (de M. Costa et al. 2016). When considering additional income and ecosystem services provided by the woody components of the system, this is an important result.

Paciullo et al. (2011) evaluated dairy heifer performance in Brazilian silvopastures planted in $B$. decumbens grass with four species of 105 dispersed mature trees ha ${ }^{-1}$ and drew comparisons with performance in similar B. decumbens open pasture. The authors concluded that a $13 \%$ increase in the $\mathrm{CP}$ content of $B$. decumbens in silvopasture compared with open pasture was sufficient to increase live weight gain of dairy heifers by $17 \%$ during the rainy season (Table 3 ). They posited that this increase in 
annual average gain could contribute to a reduction in the age of first conception and, consequently, of the first calving event.

Another study at the EMBRAPA Dairy Cattle Center in Brazil concluded that Zebu-Friesian heifers grazing in a silvopasture planted in $B$. decumbens accompanied by Acacia mangium, Mimosa artemisiana, and Eucalyptus grandis at a density of 198 trees

Table 3 Average daily gain $\left(\mathrm{g}_{\text {animal }}{ }^{-1}\right)$ and gain per area $\left(\mathrm{kg} \mathrm{ha}^{-1}\right)$, according to rearing systems and experimental year, in the rainy and dry seasons. Source: Paciullo et al.

\begin{tabular}{|c|c|c|c|c|}
\hline \multirow[t]{2}{*}{ Experimental year } & \multicolumn{2}{|l|}{ Rainy season } & \multicolumn{2}{|l|}{ Dry season } \\
\hline & Silvopastoral & Monoculture & Silvopastoral & Monoculture \\
\hline \multicolumn{5}{|l|}{ Average daily gain } \\
\hline $2004 / 2005$ & $722 \mathrm{Aa}$ & $624 \mathrm{Ba}$ & 348ab & $387 a$ \\
\hline $2005 / 2006$ & $647 \mathrm{ab}$ & $563 \mathrm{ab}$ & $298 b$ & $274 b$ \\
\hline $2006 / 2007$ & $628 \mathrm{Ab}$ & $515 B b$ & $420 a$ & $352 a b$ \\
\hline \multicolumn{5}{|l|}{ Gain per area } \\
\hline $2004 / 2005$ & 298Aa & $256 \mathrm{Ba}$ & 88 & 97 \\
\hline $2005 / 2006$ & 242ab & $230 a b$ & 75 & 68 \\
\hline $2006 / 2007$ & $258 \mathrm{Ab}$ & $211 \mathrm{Bb}$ & 105 & 89 \\
\hline
\end{tabular}

$\mathrm{ha}^{-1}$ had significantly greater live weight gain (LWG) five years after system establishment than those grazing B. decumbens monocultures (Xavier et al. 2014). Silvopasture-raised cattle averaged annual LWGs of $205 \mathrm{~kg} \mathrm{head}^{-1}$ while those in monocultures averaged $177 \mathrm{~kg} \mathrm{head}^{-1} \mathrm{yr}^{-1}$. This equates to a $16 \%$ increase in silvopastureraised heifer annual LWG. The total annual animal intake was estimated to be $4.0 \mathrm{Mg}$ $\mathrm{DM} \mathrm{ha}^{-1}$ in the silvopasture compared to $3.5 \mathrm{Mg} \mathrm{ha}^{-1}$ in the grass monoculture. Forage DM annual mean in the monoculture was non-significantly greater than that in the silvopasture, but the authors could not determine whether this was due to shading or higher forage intake by heifers in the silvopasture (Fig. 2). 
A study on sheep performance in Quintana Roo State, Mexico, analyzed five different feeding rations made up of various percentages of grasses and tree fodders and found that diets consisting of $75 \%$ or $100 \%$ tree fodder resulted in the greatest weight gains (Sosa Rubio et al. 2004). Similarly, sheep fed Gliricidia (Chadhocar and Kantharaju 1980) and Brosimum alicastrum leaves (Pérez et al. 1995) gained more weight than sheep grazing grass monocultures. In Bali, Indonesia, the production of a shrub layer creates a three strata forage system that has resulted in an increase in stocking rates by one animal ha $\mathrm{h}^{-1}$ and an increase in live weight gain by $153 \mathrm{~kg} \mathrm{ha}^{-1} \mathrm{yr}^{-1}$ (Devendra 2012).

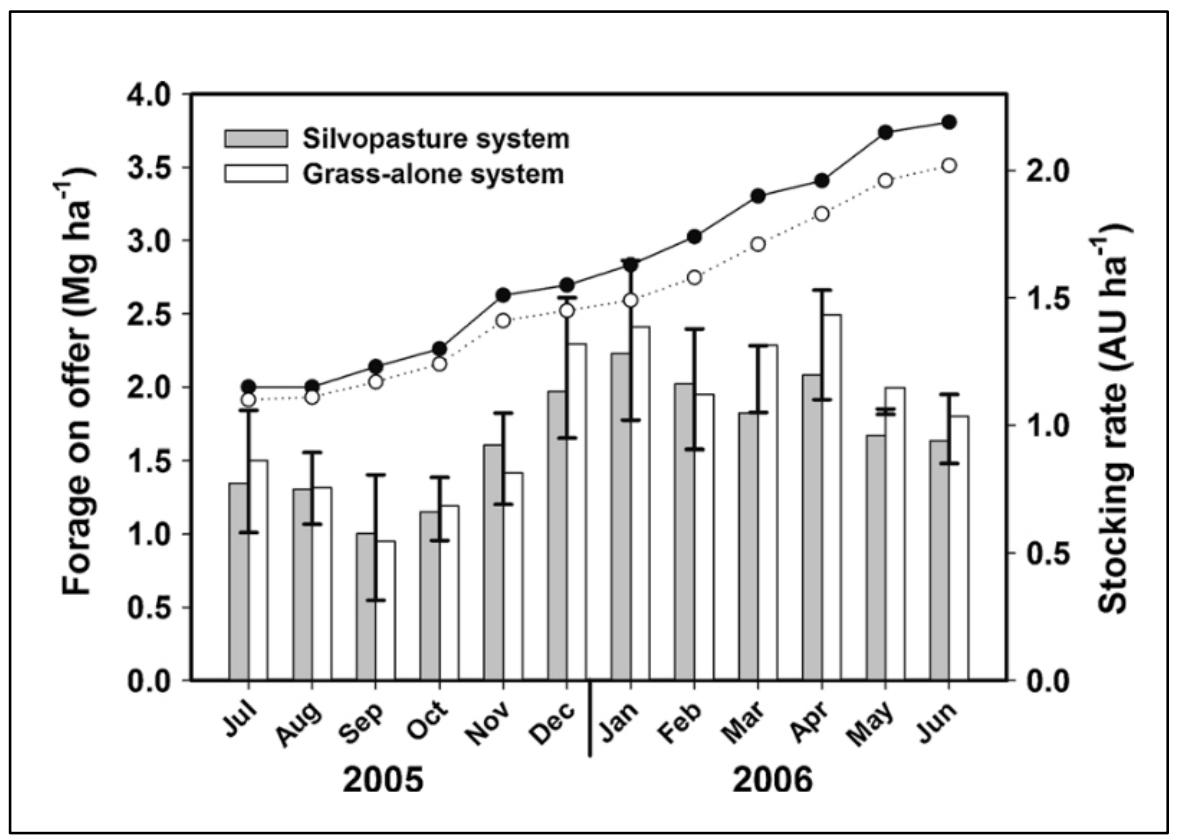

Fig. 2 Total dry matter yield of forage on offer and stocking rate of heifers (animal units ha $^{-1}$ ) from July 2005 to June 2006 in the silvopasture system and the $B$. decumbens monoculture. Dark bars and circles represent silvopasture; light bars and circles represent monoculture. Error bars represent least significant differences between means. One animul unit is equivalent to $450 \mathrm{~kg}$ of live weight. Source: (Xavier et al. 2014) 
Yamamoto and others (2007) used data on herd, milk production, and land use from 74 farms in central Nicaragua to quantify the effects of silvopastoral systems on milk production. The data indicated that silvopastoral areas, especially pasturelands with moderate tree density (tree cover approximately 20\%) have significant positive impacts on annual milk production, when overgrazing was avoided. The authors suggested that changing land use from low-density trees with natural pasture (LTNP) to moderatedensity trees with conventional pasture (MDTC) using B. brizantha could see greatest improvements in production.

Research has shown that when installed and managed effectively, ISS can increase carrying capacity by as much as four-fold per hectare ( 4.3 heads ha $\left.^{-1}\right)$, milk production by as much as $130 \%$ to $16,0001 \mathrm{ha}^{-1} \mathrm{yr}^{-1}$, and meat production by as much as ten-fold (Table 4). These gains, largely due to better distributions of biomass throughout the year, have been shown to increase farm income by at least $\$ 440$ USD ha $^{-1}$ year $^{-1}$ while sustaining long-term system resiliency (Murgueitio et al. 2011; Calle et al. 2012a; Cardona et al. 2013). Meat quality of ISS stock rivals that of those fed in feedlots, in terms of slaughtering weight and age, fat thickness and color, meat color, and marbling score (Dalzell et al. 2006). Additionally, ISS has been shown to completely eliminate the use of chemical fertilizers from operations that once relied on the application of $400 \mathrm{~kg}$ urea ha-1 year-1 $^{-1}$ Murgueitio et al. 2011). 
Table 4 Production parameters of conventional and ISS farming systems in Australia, Mexico and Columbia. Source: (Cardona et al. 2013)

\begin{tabular}{|c|c|c|c|c|c|}
\hline \multirow[b]{2}{*}{ System } & \multirow[b]{2}{*}{ Country } & \multicolumn{3}{|c|}{ Parameter } & \multirow[t]{2}{*}{ Reference } \\
\hline & & $\begin{array}{l}\text { Stocking rate } \\
\text { (AU/Ha) }\end{array}$ & $\begin{array}{l}\text { Live weight } \\
\text { gain (g/an/d) }\end{array}$ & $\begin{array}{l}\text { Meat production, } \\
\mathrm{kg} / \mathrm{Ha} / \mathrm{yr}\end{array}$ & \\
\hline \multirow{3}{*}{ Conventional } & Australia & 1.5 & 411 & 225 & Dalzell et al., 2006 \\
\hline & Mexico & 1 to 2.5 & 500 & $182-456$ & Solorio-Sánchez et al., 2011 \\
\hline & Colombia & 1.2 & 130 & 56.9 & Córdoba et al., 2010 \\
\hline \multirow{4}{*}{ ISS } & Australia & 3 & 822 & 910 & Dalzell et al., 2006 \\
\hline & Mexico & 6 & 900 & 1,971 & Solorio-Sánchez et al., 2011 \\
\hline & \multirow{2}{*}{ Colombia } & 3.5 to 4.7 & $651-790$ & $827-1,341$ & Córdoba et al., 2010 \\
\hline & & 3.5 & 793-863 & $1,013-1,103$ & Mahecha et al., 2011 \\
\hline
\end{tabular}

Part of the reason productivity is so high in ISS is that they offer a diversity of forages to the animal. Evidence indicates that the contribution of legumes to the ruminant diet results in higher performance on mixed forages compared with those grazing on grass only (Tudsri and Prasanpanich 2001). This may be due to synergistic effects between grasses and roughage within the animal's gut. Carbohydrates are needed to supply energy for rumen microbial activity to efficiently digest and synthesize proteins. Thus, synchronous availability of total non-structural carbohydrates (TNC) and crude protein $(\mathrm{CP})$ has been shown to be critical in the improvement of animal nutrition (Neel and Belesky 2015).

Another way to increase overall system productivity and output of silvopasture is to integrate a variety of livestock, either simultaneously or via the leader-follower grazing system. Manríquez-Mendoza and colleagues (2011) observed significantly greater annual meat production in a mixed-species silvopasture including both cattle and sheep 
than for silvopastures grazed by either cattle or sheep. Leader-follower systems can often out-produce other grazing systems for total animal weight gain because each animal tends to consume its optimal foods first (Shepard 2013).

Thermal Stress

Thermal stress has been shown to be responsible for reductions in feed intake, average daily gain (ADG), and milk production in dairy cows and can be caused by changes in air temperature, relative humidity, wind speed, and solar radiation (Kendall et al. 2006). Symptoms of heat stress, such as increased respiration rate and body temperature, begin to occur at $30^{\circ} \mathrm{C}$, and shade typically becomes beneficial to livestock when the temperature-humidity index (THI) is over 72 (Blackshaw and Blackshaw 1994). Thermal comfort is especially important for European or mixed European $\times$ Zebu cattle breeds, which are more sensitive to the high temperatures of the tropics than pure Zebu breeds (Kendall et al. 2006).

Several studies have shown that trees modify understory micro-climates, creating environments that can mitigate heat stress in animals (Tucker et al. 2008; Karki and Goodman 2015), increasing overall grazing time, average daily weight gain, and reproductive rates (Mitlöhner et al. 2001; Kallenbach 2009; Galindo et al. 2013). In turn, livestock have been shown to modify their behavior in the presence of trees, leading to more consistent and uniform grazing across the landscape (McIlvain and Shoop 1971; Karki and Goodman 2010). Trees can also protect animals against the dangers of extreme cold temperatures. Adequate wind protection from trees in Canada has been shown to reduce the effects of cold by more than half (Webster 1970). 
Animal Health

Managed intensive rotational grazing and silvopasture can have direct impacts on animal health, helping to prevent the spread of parasites and disease. One of the most economically damaging and widespread ectoparasites affecting livestock production is the horn fly (Hydrotaea irritans), a Eurasian fly that relies on feces or vegetative refuse for reproduction, often causing irritation and transmitting disease in livestock (Giraldo et al. 2011; Broom et al. 2013). The continual animal movement paramount to rotational grazing lowers the rate at which livestock return to paddocks where dung patties have yet to fully decompose, reducing host-parasite interactions. Additionally, multi-species leader-follower systems can be used, where free range poultry follow livestock and actively forage on horn fly larvae developing in dung patties (Greg Judy, personal communication).

Silvopastures provide environments that are conducive to the establishment of beneficial insects, including many that help rapidly degrade cattle manure, further inhibiting the spread of the horn fly. In Colombia, Giraldo and others (2011) documented significantly greater numbers of dung beetles in ISS than in conventional pasture. The authors observed an inverse relationship between dung beetle and horn fly abundance in the two cattle raising systems, which they attributed to both plant cover and the contribution of plant litter provided by L. leucocephala. Plant litter favors not only the establishment of dung beetles but also of other beneficial fauna that can control pest populations and predatorial beetles (Giraldo et al. 2011). Silvopastures have been shown to support increased numbers of birds (McDermott and Rodewald 2014), ants (Rivera et al. 2013), and other beneficial predators that can lower populations of ticks and reduce 
the incidence of diseases such as anaplasmosis, which has been shown to drop from 25 to $<5 \%$ (Yadav et al. 2019).

ISS contribute ample amounts of tree foliage to the diet, much of which contains condensed tannins, phenols, saponins, and other anti-nutritive secondary compounds that may have anti-parasitic effects. Tithonia diversifolia, a widely planted forage shrub in ISS throughout the tropics, appears to have promising effects on ruminal microbial ecology, reducing the methanogen and protozoa population and increasing the population of cellulolytic bacteria (Ruíz et al. 2014).

Still, there is some concern that silvopastoral environments could increase the presence of parasitic helminths. In southeastern Brazil, Costa and colleagues (2013) tested this hypothesis throughout a 6 month period and found no significant differences in overall weight, weight gain or helminth infestation between crossbred Holstein and Gir heifers grazed in silvopasture environments and traditional open pasture environments. In contradiction, Francisco et al. (2009) studied two groups of wild horses in Spain and concluded that silvopasture increased the presence of infection by gastrointestinal nematoda.

A relatively new area of research has examined livestock social interactions in silvopastoral systems as a diagnostic for social welfare. Améndola and others (2015) reported that heifers in an ISS maintained more stable social hierarchies and expressed more socio-positive behaviors, suggesting that animal welfare was enhanced. 


\section{Habitat for Pollinators}

Pollinator richness and density have been declining in recent years on a global scale (Thomann et al., 2013). Declines in wild bees and butterflies are linked to historical landscape modification (Burkle et al. 2013) and loss of key nesting and foraging sites (Baude et al. 2016). Pollinator decline threatens not only food security but could lead to the extinction of pollinator-dependent plants and ultimately the collapse of modern-day agriculture (Dubeux Junior et al. 2017). A report published by the Intergovernmental Science-Policy Platform for Biodiversity and Ecosystem Services identified agriculture as both a threat to pollinators and a potential solution to support them (Duvic-Paoli 2017). One key way to achieve this is through 'ecological intensification,' or the process of maintaining or enhancing agricultural productivity through the cultivation and management of beneficial biodiversity - a process not unlike silvopasture.

A study examining pollinator presence on two silvo-arable and four silvopastoral systems in the UK found that butterfly diversity was significantly higher on the agroforestry plots when compared to conventional pasture (Fig. 3). However, hoverfly and bumblebee abundance were higher in the silvoarable treatments but not for the silvopastoral treatments. The authors attributed this to strips of forbs and grasses retained in tree rows within the silvoarable plots. These so-called 'pollination reservoirs' have been shown to be crucial - even in small strips - to the provisioning of adequate pollinator habitat (Brosi et al. 2008). Moreover, planting insect-pollinated tree species may make silvopastures more attractive to pollinators (Varah et al. 2013). 


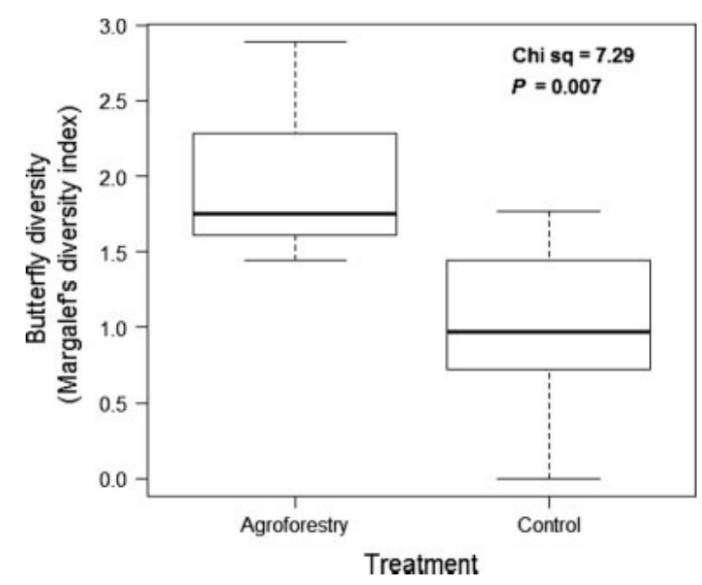

Fig. 3 Effects of treatment on butterfly diversity across all sites in the southern UK. Source: (Varah et al. 2013)

\section{Silvopasture in the Future}

Silvopasture has been shown to be an effective strategy to ecologically intensify and increase food supply in livestock production systems, but it should not be promoted in isolation of other important food security considerations. In an eye-opening report, Steinfeld and colleagues (2006) claimed that the livestock sector emerges as one of the top two or three most significant contributors to the most serious environmental problems. With more than 20 billion domestic farm animals on the planet, they may be even more of a burden for the Earth's biosphere than the current 7.7 billion humans (Hahlbrock 2009). It is time we took a careful look at where and how livestock is being produced and whether or not they hinder or advance our aims to sustain the land in perpetuity (Janzen 2011).

Much of the world's increase in livestock production is occurring through intensive concentrated animal feeding operations (CAFOs), using feed produced on arable lands that could be growing food crops for humans (Pollen 2006). A large portion 
of food energy in plant biomass is lost when it passes through animals, so that the number of people fed ha ${ }^{-1}$ of cropland declines when grain is diverted through livestock (Godfray et al. 2010). Stresses in which livestock are implicated include land use change, excretion of polluting nutrients, overuse of freshwater, inefficient use of energy, diverting food for use as feed and emission of greenhouse gasses (Janzen 2011). Thus, a worthy and prudent goal would be to decrease livestock product consumption and to be conscientious of where livestock products come from, if they are consumed.

With that said, many authors make cogent arguments for the role of animal agriculture (Janzen 2011; Hahn Niman 2014; Savory and Butterfield 2016). Livestock may compete with humans for food, but they also create protein from resources we cannot use directly - namely cellulose, from vast grasslands that cannot, or at least should not, be cultivated (Garnett 2009). Most grasslands have co-evolved with large ungulates and have even been shown to thrive best under periodic animal impact, restorative disturbances that naturally aerate and return nutrients to soils. Unlike arable cropland, perennial grasses are not regularly tilled, reducing erosion and sequestering large amounts of carbon to help mitigate climate change (Janzen 2004; Mbow et al. 2014). Carbon sequestration can be enhanced even further when combined with trees in silvopastoral systems (Udawatta and Jose 2012).

Animal agriculture is now widely engrained in the fabric of many cultures and societies. In fact, meat, milk and other animal products account for about a third of the protein consumed by humans globally and account for $40 \%$ of the global agricultural GDP (Steinfeld et al. 2006). This, combined with the growing stigma of affluence surrounding the consumption of meat is reason to believe that animal agriculture is here 
to stay. Silvopasture is an age-old practice that - if adopted more widely - could augment the benefits and minimize the stresses of livestock production.

Establishing agroforestry on land that currently has low tree cover has been identified as one of the most promising strategies to raise food production without additional deforestation (Garrity et al. 2010). However, the establishment of silvopasture is often easier said than done. In many developing countries, a lack of land tenure makes farmers reluctant to invest in the long- term endeavor of establishing trees that may ultimately benefit others than themselves. Where land holdings are small, farmers are often unwilling or unable to spare land for agroforestry establishment, even if it promises higher long-term returns (Mbow et al. 2014). In the case of ISS, start-up costs can be relatively expensive and may be entirely prohibitive without the availability of subsidies (Murgueitio et al. 2011; Calle 2013) or incentive programs like payment for environmental services (PES) (Pagiola et al. 2005). ISS are also inherently complex, often requiring extensive capacity building, training, and deployment of new technologies through outreach and extension programs (Calle 2013).

National and regional policy-makers across the globe would be wise to address the obstacles facing landholding producers and create programs to facilitate the adoption and utilization of silvopasture. As climate change continues to intensify and jeopardize global food security, silvopasture should no longer be treated as an anomaly, practiced by the few; it should be widely recognized, supported, and promulgated for the effective food provisioning tool it is, expanding and facilitating green ranching opportunities to farmers around the world. 


\section{Rationale for the Current Study}

In this chapter, we have highlighted a body of research that provides evidence for silvopasture's potential to enhance food security. However, there is still much skepticism among producers and silvopasture adoption rates remain low. There is a need for replicated on-farm demonstrations of low-input/high output silvopastures to help clarify existing doubts among producers. This could potentially encourage them to reconsider long-held, inaccurate belief systems that cattle and trees don't mix, particularly under climate change scenarios.

It is now abundantly clear that the sustainable intensification of meat production will be achieved in the long-term only with the development of working landscapes for the improved health and restoration of both ecosystems and livestock. Animal production must be attained with a minimum of external inputs. It should revolve around the planning of agricultural systems where ecological interactions and synergies between biological components replace human inputs (Cardona et al. 2013). However, there is still much to be learned about these inherently complex systems.

Recently, there has been a surge in research on the benefits of ISS (see Broom et al. 2013 for an overview). Additionally, much attention has been paid to the autoecology of neotropical timber species with implications for native species reforestation (Hall et al. 2011a). However, few studies have documented seedling growth and interspecific interactions among components in silvopastoral reforestation systems (Riedel et al. 2012). Additionally, little is known about potentially promising drought tolerant species both native and non-native - and their interactive effects on these systems. Janzen (2011) claimed that the re-greening of ecosystems will most likely come by studying - not the 
pieces such as cows, crops, soil, air, water - but their interactions. With the continuation of cattle ranching activities likely throughout much of the world, the integration of reforestation and conservation practices with ranching activities is particularly attractive and timely (Garen et al. 2011).

In the next three chapters, we present original data collected on the biophysical influences of trees on overall forage production in tropical and temperate low input systems. We examined three unique simulated silvopastures - two in the province of Los Santos, Panama and one in the state of Missouri, USA - to address the year-long competitive and facilitative effects of trees on neighboring grasses and shrubs. In chapter two, we present results on the production and nutritive quality of three commonly planted 'improved' African grasses for three light levels under mature mixed native species hardwood plantations in Panama. In chapter three, we investigate whether or not the planting of the 'fertilizer shrubs' Leucaena leucocephala and Tithonia diversifolia helps improve soil fertility and system forage productivity in newly established silvopastures in Panama. Results presented in the first two data chapters provide an assessment of important ecological interactions in simulated silvopastures at two different successional stages. In chapter four, we move to central Missouri, where we examined the initial growth, production, and nutritional value of the alternative forage shrub red mulberry (Morus rubra L.) for four light levels under a mature cherrybark oak (Quercus pagoda) plantation.

The specific objectives and hypotheses of each study are addressed in each chapter. All three studies provide important information on the cumulative effects of woody perennials on forage production of neighboring plants in three distinct 
environments. Finally, we conclude with chapter five, a summary of the major findings and implications of this research. 


\title{
Chapter 2
}

\section{Tree Density Effects on Soil, Dry Matter Production and Nutritive Value of Understory Megathyrsus maximus in a Seasonally Dry Tropical Silvopasture in Panama}

\begin{abstract}
Panama's Azuero Peninsula experiences a five-month dry season that routinely subjects cattle to prolonged stress that can result in substantial losses in productivity. Silvopasture, an agroforestry practice combining forages, livestock, and trees, has been shown to optimize system productivity and mitigate the effects of environmental stress on livestock; however, few ranchers in Panama incorporate trees into pastures for long-held beliefs that trees and grass do not mix. We studied three cultivars of Guinea grass (Megathyrsus maximus cv. Massai, cv. Mombaza, and cv. Tanzania) planted under open (O), moderate (M), and dense (D) tree coverage. We hypothesized that changes in soil chemical and physical properties, grass dry matter production, and nutritive content would be optimized in $\mathrm{M}$ in accordance with the stress gradient hypothesis, which predicts an increase in plant facilitation with increasing environmental stress. Results showed no beneficial changes in soil chemical properties due to higher tree densities, but bulk density decreased significantly with increasing tree cover. No differences existed for soil moisture between treatments. O produced significantly greater quantities of dry matter than $\mathrm{M}$ and $\mathrm{D}$, and Massai produced significantly greater quantities of forage than Mombaza, but not compared to Tanzania. Nutritive value improved in the shade, with highest $\mathrm{CP}$ and lowest fiber (ADF and NDF) values reported for $\mathrm{D}$ and $\mathrm{M}$. No differences in nutritive value were found among cultivars. Massai showed the greatest tolerance to drought, producing the most forage accumulation in the early part of the dry season, but only in M. Results partially support the hypothesis, suggesting that forage accumulation is greatest in M for Massai early in the dry season, but greatest in $\mathrm{O}$ over the year. This observed extension of the growing season under moderate tree densities could result in reduced animal weight loss between the months of January and April for this region. Research is needed on animal performance under similar tree densities to corroborate the findings reported here.
\end{abstract}

Key words: Tree-grass interactions, forage production, dry tropics, silvopastoral systems 


\section{Introduction}

\section{Background}

Deforestation and forest degradation have resulted in the widespread loss of native forests across much of the world. One of the key drivers of tropical deforestation in the Neotropics is livestock production (Wassenaar et al. 2006). Of the 22 million hectares of forest lost between 1960 and 1995, 21 million hectares were then used for cattle production (Broom et al. 2013). Meanwhile, human demand for food and other products is increasing rapidly (Godfray et al. 2010). On Panama's Azuero Peninsula, cattle-ranching has been the dominant land use since the early part of the last century when the vast majority of the native dry tropical forests were converted to pasture (Janzen 1988, Griscom et al. 2011). Widespread deforestation resulted throughout the Azuero's eastern province of Los Santos due to government incentives for agricultural expansion, predominantly for cattle-ranching activities (Heckadon-Moreno 1984, 2009). Today, the deforestation rate on the Azuero Peninsula ranks among the highest in Panama (ANAM 2014). Over the past 30-40 years, high cattle stocking rates, repeated burning, and removal of native vegetation has degraded pasture lands, resulting in severe erosion and an overall decline in productivity throughout the region (Heckadon-Moreno 1984, Janzen 1988, Griscom et al. 2011).

Panama's Azuero Peninsula experiences a five-month dry season that routinely subjects cattle to prolonged stress that results in substantial weight loss and even death. Over the past three years, ranchers in the province of Los Santos have reported the deaths of over 500 cattle, with scores more losing over $115 \mathrm{~kg}$, a weight that translates to an economic loss of $\$ 150$ per head (Cortez 2013). Climate change is expected to continue to 
have far-reaching consequences for animal production through its effects on forage and range productivity and heat related stress on the animal. Under climate change scenarios, water will become the main limiting factor to all livestock systems (Steinfeld et al. 2006; de Fraiture et al. 2010). In fact, extended droughts have become increasingly commonplace on the Azuero Peninsula. This, coupled with a demand for animal products that is predicted to double in the first half of this century, is cause for concern (Godfray et al. 2010).

\section{Silvopasture}

In response to widespread deforestation in the 1980's, the Panamanian government began subsidizing landowners to plant non-native Teak (Tectona grandis) plantations all across the isthmus (Sloan 2008; Griscom and Ashton 2011a). Recent efforts have been made to reforest and restore native tree species because they are perceived to produce an increased diversity of socially sensitive goods and ecosystem services (Hall et al. 2011b). In Los Santos, where cattle ranching is the primary form of agriculture, a sensible first step in mitigating the harsh impacts of climate change could be to combine the goods and services of timber production and ranching with the use of silvopasture.

Silvopasture is an agroforestry practice where trees and livestock are deliberately combined with improved pasture plants to form a carefully designed system, integrating intensive animal husbandry, silviculture, and forage agronomy practices (Sharrow et al. 2009). Silvopasture can improve the balance between production and conservation, ensuring the availability of highly nutritious forage, reducing stress in cattle, capturing 
and storing carbon, and favoring biodiversity by providing habitat that supports a diversity of plants and animals (Ibrahim et al. 2010; Galindo et al. 2013).

It is well-established that trees have both competitive (negative) and facilitative (positive) effects on the organisms around them (Jose et al. 2004; Jose et al. 2017). Canopy solar interception results in lower light transmittance, decreasing the photosynthetic rate of understory vegetation. Trees have been shown to compete vigorously for water and nutrients and can even emit allelopathic chemicals that impede the growth of surrounding vegetation. However, canopy interception can also provide protection from desiccating winds, reduce soil surface temperature and soil evapotranspiration (Belsky et al. 1989; Belesky 2005), which can increase overall soil moisture content (Vetaas 1992). Some trees can fix atmospheric Nitrogen and provide up to $650 \mathrm{~kg} \mathrm{~N} \mathrm{yr}^{-1}$, more than enough to fulfill crop $\mathrm{N}$ needs for sustained yield (Nygren et al. 2012). Leaf litter under trees has been shown to improve the physical properties of the surface soil, increasing soil nutrients and organic matter (Belsky 1994). As a result, the content of carbon, phosphorus, and nitrogen has been shown to gradually decline as a function from the distance of the trunk, resulting in significantly lower levels in the open ground than in sub-canopy soil (Belsky et al. 1989; Tiedemann and Klemmedson 2008).

Elevated nutrient levels can improve the forage quality of sub-canopy grasses, attracting grazers that return nutrients to the soil. This, combined with the trapping of wind and water-borne sediments by trees can contribute to an 'island of fertility' effect (Belsky et al. 1989; Dohn et al. 2013). Trees roots can also decrease the bulk density of the soil, creating the macro-porosity favorable to the infiltration of water, increasing water-holding capacity (Malmer et al. 2010). These benefits, combined with the selection 
of appropriate tree and forage species, can sometimes result in increased levels of productivity when compared with monocultures.

A number of studies have been conducted on the genetic development and expansion of pasture grasses for use with intensive cattle production and silvopastoral systems. In response to various pathogens and pest outbreaks that have rendered common pasture grasses like Marandu (Urochloa brizantha) susceptible to mass die-off, research institutions have been selectively breeding, hybridizing, and experimenting with new grass varieties (Fernandes et al. 2014). More recently, attention has been paid to improving drought and shade tolerance among cultivars for use in silvopastoral systems.

Guinea grass (Megathyrsus maximus Jacq.) is one of the most important species for cattle production in tropical and subtropical regions (Paciullo et al. 2017) and, despite being a $\mathrm{C}_{4}$ grass, many developed cultivars show medium levels of tolerance to shade (Santiago-Hernández et al. 2016). The genus Megathyrsus has an array of diversity, with most species standing erect, from 0.5 to $3.5 \mathrm{~m}$ high and is recommended for regions with annual rainfall from 800 to $1800 \mathrm{~mm}$ in well-drained soil with medium to high fertility (Muir and Jank, 2004). The cultivars Massai, Mombaza, and Tanzania, developed for increased productivity with simultaneous drought and shade tolerance characteristics, were released from the M. maximus breeding program at EMBRAPA (Brazilian Agricultural and Cattle Research Enterprise) and are currently among the most popular Guinea Grass cultivars in Latin America (Paciullo et al. 2017).

Ecological theory suggests that facilitation presides over competition along a gradient of increasing abiotic stress (Bertness and Callaway 1994; Brooker and Callaghan 1998; Dohn et al. 2013). The stress gradient hypothesis conjectures that neighboring 
organisms are more likely to facilitate each other's growth and fitness under conditions of high environmental stress, such as high disturbance frequency and low resource availability (Bertness and Callaway 1994; Brooker and Callaghan 1998; Dohn et al. 2013). In xeric environments where water is the limiting factor, growth and development of many herbaceous species are facilitated by tree canopies through the improvement in moisture regimes (Joffre and Serge, 1993), soil nutrients, and organic matter (Kellman 1979). Moustakas et al. (2013) demonstrated that tree effects on grass biomass across a precipitation gradient in a subtropical savanna were facilitative in drier sites, with higher grass biomass observed beneath tree canopies than outside.

We expect that environmental conditions on our study site are such that the stress gradient hypothesis could be supported. The objectives of this study were to: 1) evaluate differences in dry matter production and nutritive value among three cultivars of $M$. maximus (cv. Massai, cv. Mombaza, and cv. Tanzania) under open (O), moderate (M), and dense (D) tree coverage, 2) quantify understory light levels with the use of hemispherical photography, and 3) test for differences in soil chemical and physical properties among treatments after the establishment of the grasses.

We hypothesized that dry matter production and nutritive quality would reach their peak in M. We further hypothesized that cation exchange capacity (CEC), base saturation (BS), and corresponding soil fertility indicators like organic matter and the exchangeable cations $\mathrm{Mg}, \mathrm{Ca}$, and $\mathrm{K}$ would be highest in $\mathrm{D}$, but soil moisture would be highest for $\mathrm{M}$ during the dry season due to hydrological improvements under a sparse canopy. 


\section{Materials and Methods}

Study site

This study was conducted near the Achotines Tuna Laboratory on privatelyowned land in the dry tropical forest region (Holdridge 1967) of Los Santos Province on the Pacific side of Panama (Fig. 2; $7^{\circ} 15^{\prime} 30^{\prime}$ 'N, 8000'15'W). The area receives a longterm average of $1678 \mathrm{~mm}$ of rain per year, with an extended five-month dry season between late November and late April (Fig. 1). According to the Soil Atlas of Latin America, soils are classified as Dystric Cambisols (Cmdy) and are young and relatively nutrient rich, although degraded from decades of overgrazing (Gardi et al. 2015). Soil textures range from loam to clay loam (Table 1) with an average soil $\mathrm{pH}$ of $5.54( \pm 0.17)$. The topography is undulating, with slopes ranging between 18 and $40 \%$ grade (Diogenes Ibarra, personal communication).

In 2005 , twenty native tree species were planted on 31 hectares. Areas that remain to be reforested are now a mosaic of pastures of the African grasses Faragua (Hyparrhenia rufa) and Guinea grass (M. maximus), riparian forested zones, isolated trees, and live fences (Griscom et al. 2009). The land is currently being rotationally grazed by a herd of 30 Brahman cattle, which are sold and restocked annually. Study plots were established in and alongside a mixed native species tree plantation established in 2005 (11 years old; Fig. 3). The plantation was dominated by Dalbergia retusa Hemsl. (40\% of the individuals), Platymiscium pinnatum (Jacq.) Dug. (18\% of the individuals), Swietenia macrophylla King. (10\% of the individuals), and Diphysa americana Benth. ( $10 \%$ of the individuals) (Table 2$)$. 


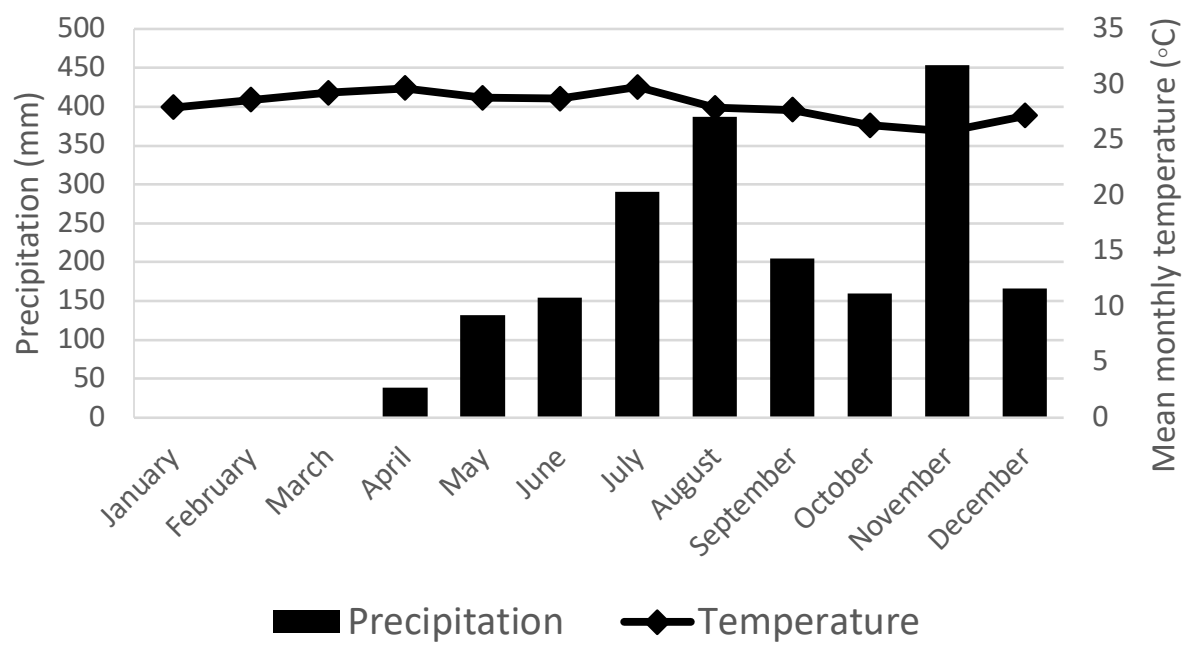

Fig. 1 Precipitation and mean monthly temperature near Playa Venao, Panama in 2016 (A portion of the data was provided by (ETESA 2018)

Table 1 Soil texture determined from three sampling depths $(0-5,5-10$, and 10-15 cm) from one location within each of the three tree density treatments, moderate $(\mathrm{M})$, dense (D), and open (O).

Soil Texture (\%)

\begin{tabular}{lcccc} 
Soil depth & Sand & Silt & Clay & $\begin{array}{c}\text { Texture } \\
\text { class }\end{array}$ \\
\hline $\begin{array}{l}\text { Profile } 1 \\
\text { (M) }\end{array}$ & & & & \\
\hline $0-5$ & 47.5 & 36 & 16.5 & Loam \\
$5-10$ & 43 & 34 & 23 & Loam \\
$10-15$ & 39 & 33 & 28 & Clay Loam \\
\hline $\begin{array}{l}\text { Profile } 2 \\
\text { (D) }\end{array}$ & & & & \\
\hline $0-5$ & 35.5 & 38 & 26.5 & Loam \\
$5-10$ & 33 & 36.5 & 30.5 & Clay Loam \\
$10-15$ & 29 & 38 & 33 & Clay Loam \\
\hline $\begin{array}{l}\text { Profile } 3 \\
\text { (O) }\end{array}$ & & & & \\
\hline $0-5$ & 48 & 37 & 15 & Loam \\
$5-10$ & 46 & 33 & 21 & Clay Loam \\
$10-15$ & 45 & 33 & 22 & Clay Loam
\end{tabular}


Table 2 Tree species and their respective representation in the 2005 plantation at the IDB Forestal Ranch, near Playa Venao, Panama. Source: (Griscom and Ashton 2011b)

\begin{tabular}{|c|c|c|c|}
\hline Species & $\begin{array}{c}\text { Successional } \\
\text { status }\end{array}$ & Attributes & Representation \\
\hline Dalbergia retusa Hemsl. & $\begin{array}{l}\text { Long-lived } \\
\text { Pioneer }\end{array}$ & $\begin{array}{l}\text { Nitrogen-fixing, } \\
\text { Timber }\end{array}$ & $40 \%$ \\
\hline Swietenia macrophylla King. & $\begin{array}{l}\text { Long-lived } \\
\text { Pioneer }\end{array}$ & Fast growth, Timber & $10 \%$ \\
\hline Cedrela odorata L. & Pioneer & Fast growth, Timber & $5 \%$ \\
\hline Tabebuia rosa (Bertol) DC. & $\begin{array}{l}\text { Long-lived } \\
\text { Pioneer }\end{array}$ & Fast growth, Timber & $5 \%$ \\
\hline $\begin{array}{l}\text { Platymiscium pinnatum } \\
\text { (Jacq) Dug. }\end{array}$ & Pioneer & $\begin{array}{l}\text { Nitrogen-fixing, } \\
\text { Timber }\end{array}$ & $18 \%$ \\
\hline $\begin{array}{l}\text { Manilkara zapota (Pittier) } \\
\text { Gilly. }\end{array}$ & $\begin{array}{l}\text { Late- } \\
\text { successional }\end{array}$ & Wildlife, NTFP & $7 \%$ \\
\hline $\begin{array}{l}\text { Calycophyllum } \\
\text { candidissimum (Vahl) DC. }\end{array}$ & $\begin{array}{l}\text { Late- } \\
\text { successional }\end{array}$ & Fast growth, Timber & $1 \%$ \\
\hline Diphysa americana Benth. & $\begin{array}{l}\text { Long-lived } \\
\text { Pioneer }\end{array}$ & $\begin{array}{l}\text { Nitrogen-fixing, } \\
\text { Timber }\end{array}$ & $10 \%$ \\
\hline $\begin{array}{l}\text { Cordia alliodora (Ruiz \& } \\
\text { Pav.) Oken. }\end{array}$ & $\begin{array}{l}\text { Long-lived } \\
\text { Pioneer }\end{array}$ & Fast growth, Timber & $1 \%$ \\
\hline $\begin{array}{l}\text { Tabebuia guayacan (Seem) } \\
\text { Hemsl. }\end{array}$ & $\begin{array}{l}\text { Long-lived } \\
\text { Pioneer }\end{array}$ & Fast growth, Timber & $2 \%$ \\
\hline Albizia saman (Jacq) Merr. & $\begin{array}{l}\text { Long-lived } \\
\text { Pioneer }\end{array}$ & $\begin{array}{l}\text { Nitrogen-fixing, } \\
\text { Timber }\end{array}$ & $1 \%$ \\
\hline
\end{tabular}


A geometrical thinning was done in May of 2016 to establish an even distribution of shading in the moderately shaded treatment $(\mathrm{M})$, where plantation overstory basal area was reduced from $13.45 \mathrm{~m}^{2} \mathrm{ha}^{-1}$ (Dense shade, D) to $6.44 \mathrm{~m}^{2} \mathrm{ha}^{-1}$ (Moderate shade, M) (Table 3). This $48 \%$ reduction of basal area corresponds to stocking levels that permit understory light levels between 35 and 50\% of that found in the open (Garrett et al. 2004; Orefice et al. 2017). Open pasture treatments (O) were established directly adjacent to the plantation with similar edaphic and topographic conditions, pre-determined by sampling and analysis of the soils. Plots were fenced to avoid the entry of cattle and cleared of all vegetation with machetes. Roundup ${ }^{\circledR}$ herbicide (Glyphosate) was applied evenly to all plots prior to the broadcast seeding of grass at a seed rate of $8 \mathrm{~kg} \mathrm{ha}^{-1}$ of pure and viable seed (PVS). No fertilizer was applied to any of the plots at any time.

Table 3 Overstory composition in a mixed species native tree plantation established in 2005 at the IDB Forestal Ranch, near Playa Venao, Panama. Trees were geometrically thinned to approximate a $50 \%$ reduction in basal area.

\begin{tabular}{lcc}
\hline \multicolumn{1}{c}{ Measurement } & \multicolumn{2}{c}{ Treatment } \\
\hline Trees $\left.^{c} \mathrm{ha}^{-1}\right)$ & $931(55)$ & $503.15(76.65)$ \\
Diameter at breast height $(\mathrm{cm})$ & $12.43(3.14)$ & $11.90(2.78)$ \\
Basal diameter $(\mathrm{cm})$ & $19.32(4.98)$ & $17.62(4.32)$ \\
Height $(\mathrm{m})$ & $8.12(1.36)$ & $7.82(1.45)$ \\
Basal area $\left(\mathrm{m}^{2} \mathrm{ha}^{-1}\right)$ & $13.45(0.56)$ & $6.44(0.66)$ \\
Mean quadratic Diameter $(\mathrm{cm})$ & $13.52(0.216)$ & $13.03(1.24)$ \\
Relative Density & $58 \%(2.4 \%)$ & $28 \%(2.4 \%)$ \\
\hline
\end{tabular}

Means are reported with standard error in parentheses, $n=9$. Relative density is the reported basal area of a stand in relationship to the maximum basal area reported for that forest type and size class. Source: (Ewel 1977) 

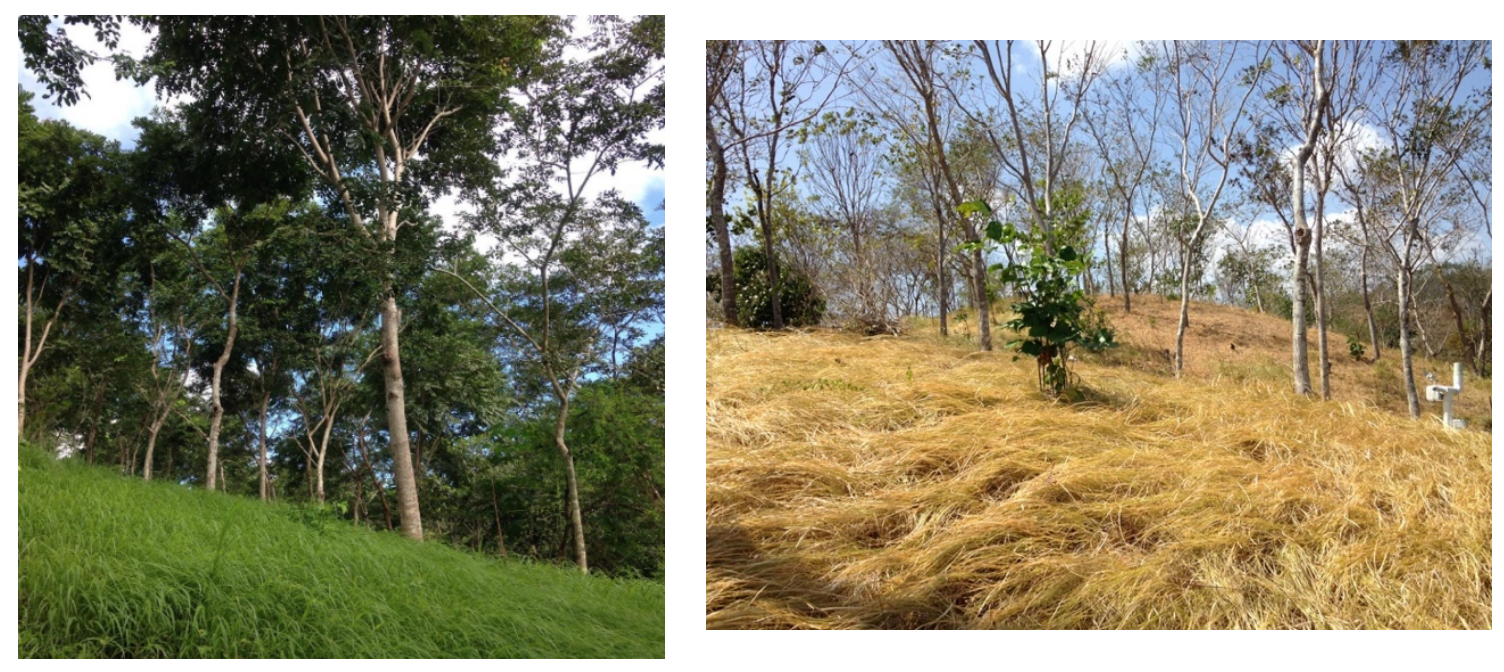

Fig. 2 Two photos from the mixed native species plantation established in 2005 at the IDB ranch near Playa Venao, Panama, illuminating stark differences between the rainy (left) and dry (right) seasons.

\section{Experimental Design}

A completely randomized split-plot design was used with tree density as the main plot factor and grass type as the split-plot factor. Tree density consisted of open $(\mathrm{O})$, moderately shaded (M), and densely shaded (D) treatments and grass type was one of three randomly selected M. maximus cultivars: cv. Massai, cv. Mombaza, and cv. Tanzania. Each main plot factor was replicated three times in $1 / 3$ ha plots, each of which was divided into four equal-sized quadrants planted with one of the three randomly selected grass varieties. The remaining quadrant was not planted. Each plot was given a $6 \mathrm{~m}$ buffer to prevent outside influence from neighboring treatments (Fig. 3). 


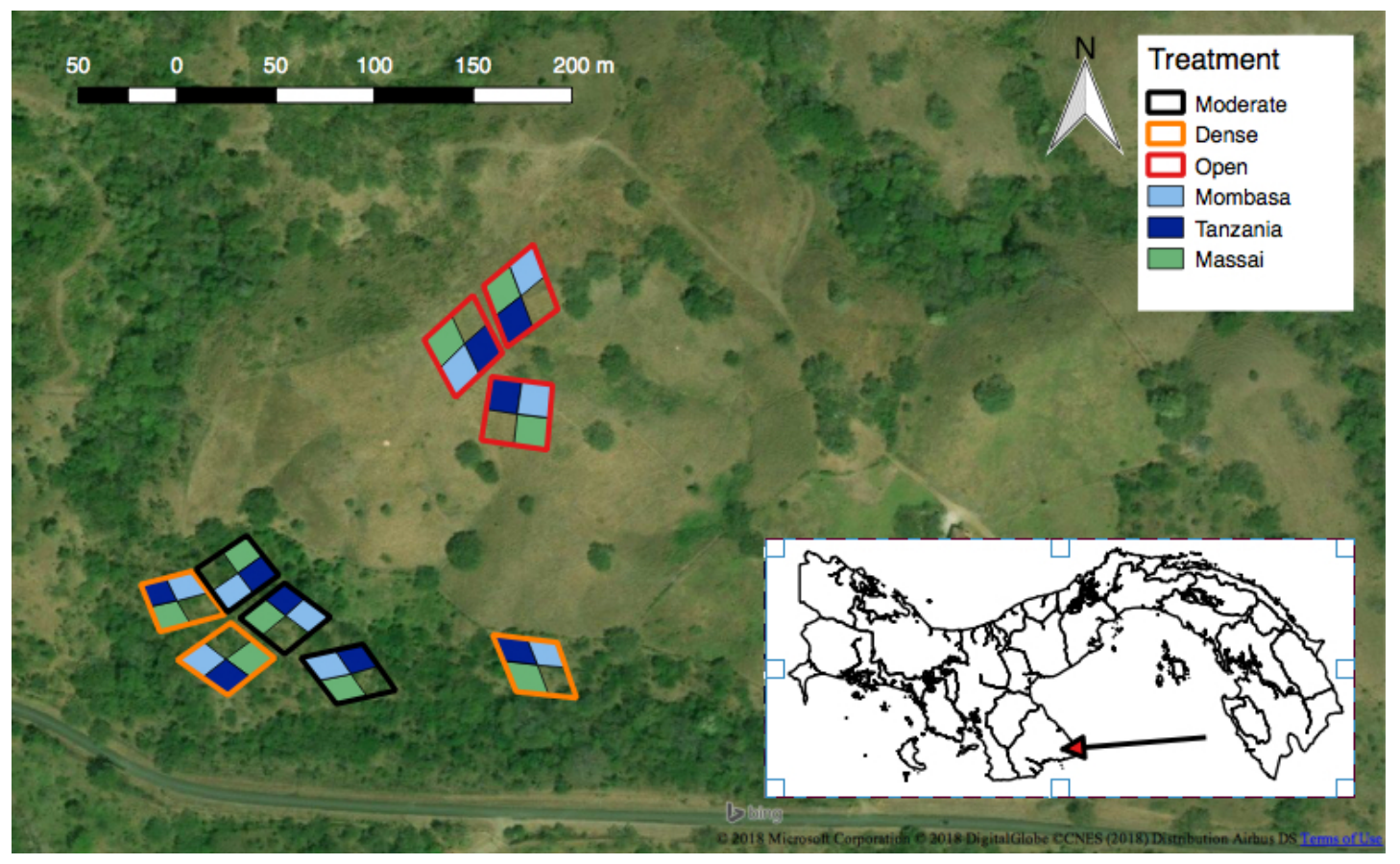

Fig. 3 Completely randomized layout with a split plot design for M. maximus (varieties Massai, Mombasa, and Tanzania) at the IDB Forestal ranch in Los Santos, Panama.

\section{Understory Light Environment}

Light quantity was determined by measuring solar transmission radiation with hemispherical photography (Fig. 4). Upward hemispherical images were photographed during the dry season (April) and wet season (November) of 2016 using a Cannon EOS Rebel with an Opteka Vortex Fisheye Lens. Images were taken $1 \mathrm{~m}$ above the ground on a tripod equipped with a Delta-T devices mount used for horizontal leveling and northsouth orientation of the camera. Measurements were taken at dawn to maximize light evenness. Three photographs were taken at the middle and corners of each plot with automatic exposure compensation and bracketing at $-2.0,-1.0$, and 0 . This was done to mitigate the effects of over-exposure that can result from using the automatic exposure in 
dense canopies. Images were analyzed with Hemiview software (Delta-T Devices Ltd., Cambridge, U.K.), which classifies pixels into two classes: open sky and obstructed sky. The software calculates the global site factor (GSF), which is the sum of direct and diffuse radiation (excluding reflected radiation) entering through canopy openings as a proportion of the amount of radiation that would fall on the same point given no overhead obstructions over the course of a year (Griscom et al. 2009). Values range from 0 to 1 , which 0 being no radiation (complete sky obstruction) and 1 being the radiation for an open location, where the sky is completely visible (Rich et al. 1999).
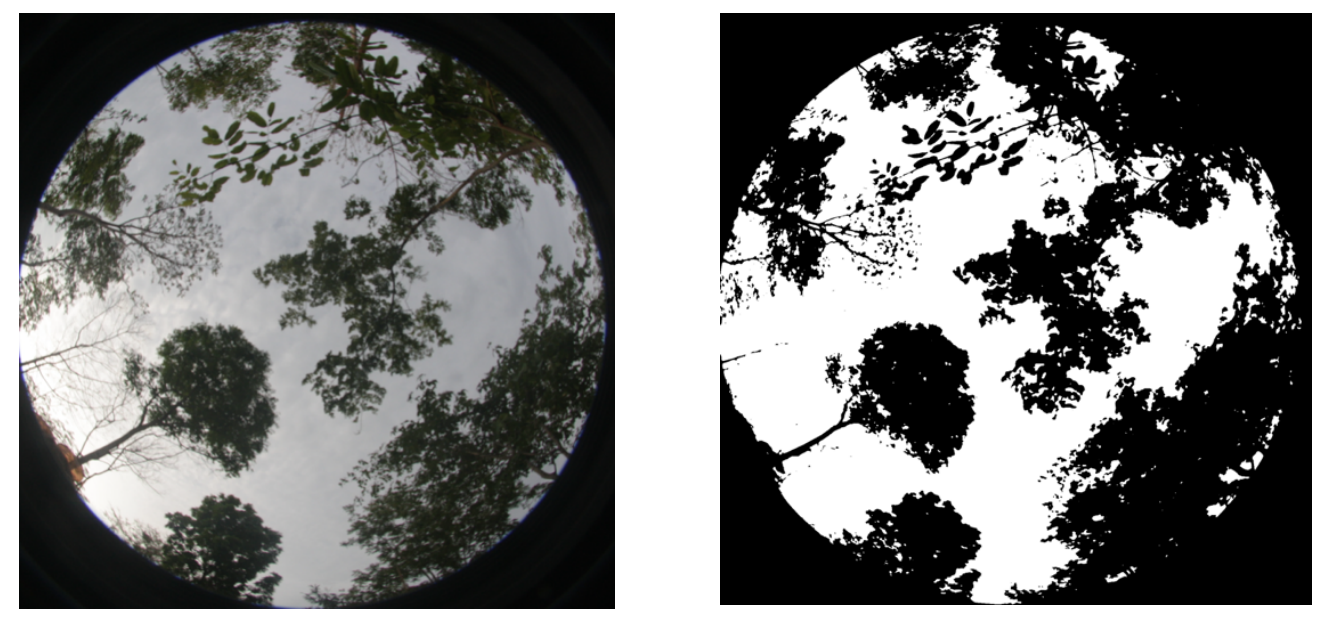

Fig. 4 Images of the canopy captured with hemispherical photography were analyzed with Hemiview software to generate Global Site Factor (GSF) to quantify understory light levels.

\section{Soil Properties}

Soil samples were collected preliminarily to confirm that all plots were relatively homogeneous and again one year later after grass was established. Six randomly distributed soil samples $(200 \mathrm{~g})$ were collected at $0-15 \mathrm{~cm}$ depth with an auger from each plot and analyzed for chemical and physical properties at the Smithsonian Tropical 
Research Institute (STRI) in Panama City, Panamá. Inductively coupled plasma optical emission spectroscopy (ICP-OES) was used with a $\mathrm{BaCl}_{2}$ solution to determine exchangeable $\mathrm{Ca}, \mathrm{Mg}, \mathrm{K}, \mathrm{Mn}, \mathrm{Fe}, \mathrm{Al}, \mathrm{Zn}, \mathrm{B}$, and the Mehlich-3 extraction (Mehlich 1984) technique was used to estimate P. Base saturation was calculated by summing the exchangeable cations. Effective Cation exchange capacity (ECEC, cmol (+) $\left.\mathrm{kg}^{-1}\right)$ was calculated by summing the basic and acidic exchangeable cations and Base Saturation (BS, \%) was calculated by dividing the Total Exchangeable Bases (TEB) by the ECEC and multiplying by 100 . Another set of samples were sent to the soil testing laboratory at the University of Missouri where they were analyzed for organic matter $(\%)$, total carbon (TC, \%), and total nitrogen (TN, \%). Total carbon and nitrogen were determined by dry combustion using a $\mathrm{CHN}$ analyzer and organic matter was estimated by loss on ignition.

Bulk density was measured using a metal cylinder with a volume of $100 \mathrm{~cm}^{3}$.

Three depths, $0-5 \mathrm{~cm}, 5-10 \mathrm{~cm}$, and $10-15 \mathrm{~cm}$, were sampled and sent to the laboratory where they were weighed wet, dried at $105^{\circ} \mathrm{C}$, and weighed again to determine gravimetric soil moisture and bulk density. Texture was determined using particle size analysis.

\section{Soil Volumetric Water Content (VWC)}

Soil moisture was evaluated once every two months using the Time-DomainReflectometry method and a TDR meter (Field Scout ${ }^{\mathrm{TM}}$ TDR Soil Moisture Meter 100, using settings for high clay soil). Soil moisture, also known as volumetric water content (VWC), is the ratio of the volume of water to the total volume of soil. This was measured 
at four depths $(3.8,7.5,12$, and $20 \mathrm{~cm})$ systematically at twelve locations across each plot for the months of January, March, May, July, September, and November in 2016.

Grass Dry Matter Production and Nutritive Value

Improved forages were broadcast seeded on June 5, 2016. Four measurements were taken to represent two sampling seasons: wet (November 5 and December 5, 2016), and dry (February 5 and April 5, 2017). At the end of each sampling period, grass within each plot was cut to a uniform height of $20 \mathrm{~cm}$ above the soil and was left to grow for 30 days and 60 days to resemble rotational stocking during the wet and dry seasons, respectively. Eight locations were systematically distributed across each plot where grasses were sampled in square grids $(0.5 \mathrm{~m} \times 0.5 \mathrm{~m})$ within a $3 \mathrm{~m}$ edge buffer to minimize potential edge effects. Grass wet matter was evaluated by cutting the grass to $20 \mathrm{~cm}$ in height with hedge shears, putting clippings into a burlap sack and immediately weighing (Fernandes et al. 2014). Samples were quartered to extract a $400 \mathrm{~g}$ subsample that was sent to the Cooleche Laboratory (Cooperativa de S/M de Productores de Leche) in Concepción, Panama. Samples were dried at $60^{\circ} \mathrm{C}$ for 48 hours to weight constancy before determination of dry biomass weight. Samples were then ground with a hammer mill to pass a $1 \mathrm{~mm}$ screen and analyzed with wet chemistry techniques to determine dry matter percent crude protein $(\mathrm{CP}, \%)$, acid detergent fiber (ADF, \%), neutral detergent fiber (NDF, \%), total digestible nutrients (TDN, \%), and relative feed value (RFV). 


\section{Data Analysis}

Shade effects on grass dry matter yield $\left(\mathrm{kg} \mathrm{ha}^{-1}\right)$ and nutritive value were analyzed with a two-way analysis of variance (ANOVA) using a mixed model with a split plot in space and time (Steel and Torrie 1980). The split plot design of this experiment considered treatments $(\mathrm{O}, \mathrm{M}$, and $\mathrm{D})$ main plots, cultivar as sub-plots, and sampling dates as sub-sub-plots (Steel and Torrie 1980). Sampling dates were analyzed as repeated measures. For light quantity (GSF, \%) and soil chemical and physical properties, twoway ANOVAs were conducted on treatments, with sampling dates analyzed as repeated measures. Bulk density and volumetric soil moisture were also analyzed with a mixed model using a split plot in space and time. Treatment (O, M, and D), soil depth, sampling date, and their interactions were considered fixed effects while the replicate, treatment nested under replicate, and sampling date nested under treatment and replicate were considered random effects.

All variables were tested for normality, $\log _{10}$ transformed when necessary, and analyzed using the MIXED procedure in SAS (SAS Institute 2010). Pairwise comparisons were performed using the Tukey-adjusted least squares method (LSMeans) and main effects and all interactions were considered significant when $\alpha=0.05$.

\section{Results}

Forage Dry Matter Production

Overall, O yielded $28.14 \%$ and $52.08 \%$ more forage than $\mathrm{M}$ and $\mathrm{D}$, respectively. Significant differences existed between treatments O $\left(2730.75 \mathrm{~kg} \mathrm{ha}^{-1}\right), \mathrm{M}(1962.25 \mathrm{~kg}$ $\left.\mathrm{ha}^{-1}\right)$ and $\mathrm{D}\left(1308.44 \mathrm{~kg} \mathrm{ha}^{-1}\right)(\mathrm{P}=0.0003)$. Forage biomass of Massai $\left(2041.89 \mathrm{~kg} \mathrm{ha}^{-1}\right)$ 
was significantly greater than Mombaza (1963.45 $\left.\mathrm{kg} \mathrm{ha}^{-1}\right)$ but not for Tanzania (1996.10 $\left.\mathrm{kg} \mathrm{ha}^{-1}\right)(\mathrm{P}=0.0112)$. Mean dry matter yield was significantly different for all months ( $\mathrm{P}$ $=0.0001)$ with November yielding the most (3845.77 $\left.\mathrm{kg} \mathrm{ha}^{-1}\right)$ and April yielding the least $\left(153.57 \mathrm{~kg} \mathrm{ha}^{-1}\right)$. There was a significant month*treatment interaction $(\mathrm{P}=0.0001)$, although no difference existed between treatments for the month of April. When seasons were analyzed, there was significantly more dry matter produced during the wet season $(\mathrm{P}=0.0001)$ than during the dry season. There was a treatment*cultivar*month interaction $(\mathrm{P}=0.0001)$, with significantly greater dry matter yield for Massai in $\mathrm{M}$ than for $\mathrm{D}$ and $\mathrm{O}$ during the month of February $(\mathrm{P}=0.0003$ and $\mathrm{P}=0.0409$, respectively; Fig. 5). Means and standard errors of these variables are presented by treatment and season in Table 4 and dry matter yield harvest ${ }^{-1}$ is shown in Figure 6.

Forage Nutritive Value

Crude protein $(\mathrm{CP})$ levels were significantly affected by treatment $(\mathrm{P}=0.0138)$ and season $(\mathrm{P}=0.0129)$. Shade increased overall crude protein levels, with means of 7.76, 8.82, and $9.62 \%$ in $\mathrm{O}, \mathrm{M}$, and $\mathrm{D}$, respectively. Pairwise comparisons showed that significant differences existed between $\mathrm{D}$ and $\mathrm{O}(\mathrm{P}=0.0055)$ and $\mathrm{M}$ and $\mathrm{O}(\mathrm{P}=0.036)$. Grasses sampled during the dry season had higher overall CP content than grasses sampled during the rainy season $(P=0.0165)$. There were no significant differences in CP content between the three cultivars $(\mathrm{P}=0.0690)$, however, Tanzania had consistently numerically greater CP levels than Mombaza and Massai (Table 5). There were no significant interactions. 
Table 4 Dry matter production $\left(\mathrm{kg} \mathrm{ha}^{-1}\right)$ for the M. megathyrsus cultivars Massai, Mombaza, and Tanzania under open (O), moderate (M), and dense (D) tree density treatments for the wet and dry season of 2016-2017.

\begin{tabular}{|c|c|c|c|c|c|c|}
\hline \multirow[t]{3}{*}{ Treatment } & \multicolumn{6}{|c|}{ Wet Season } \\
\hline & \multicolumn{2}{|c|}{ Massai } & \multicolumn{2}{|c|}{ Mombaza } & \multicolumn{2}{|c|}{ Tanzania } \\
\hline & Nov & Dec & Nov & Dec & Nov & Dec \\
\hline $\mathrm{D}$ & 2576 (392) Aal & 2091 (450) Ab1 & 2562 (232) Aa1 & 2053 (388) Ab1 & 2620 (272) Aa2 & $2001(365)) \mathrm{Ab} 2$ \\
\hline M & 3992 (497) Ba1 & 2905 (425) Bb1 & $3576(165) \mathrm{Ba} 2$ & 2782 (163) Bb2 & $3738(180) \mathrm{Ba} 2$ & 2854 (202) Bb2 \\
\hline \multirow[t]{4}{*}{$\mathrm{O}$} & 5293 (296) Ca1 & 4652 (390) Cb1 & 5086 (162) Ca2 & 4624 (342) Cb1 & 5169 (187) Ca2 & 4634.43 (390) Cb1 \\
\hline & \multicolumn{6}{|c|}{ Dry Season } \\
\hline & \multicolumn{2}{|c|}{ Massai } & \multicolumn{2}{|c|}{ Mombaza } & \multicolumn{2}{|c|}{ Tanzania } \\
\hline & Feb & Apr & Feb & Apr & Feb & Apr \\
\hline $\mathrm{D}$ & 1124 (123) Ac1 & 135 (29) Ad1 & 1051 (188) Ac2 & 123 (48) Ad2 & 1127 (91) Ac1 & $128(55) \mathrm{Ad} 2$ \\
\hline M & 1479 (158) Bc1 & 175 (75) Ad1 & 1497 (124) Bcl & $151(70)$ Ad1 & $1548(92) \mathrm{Bc} 2$ & 168 (49) Ad1 \\
\hline $\mathrm{O}$ & 936 (86) Cc1 & $172(80)$ Ad1 & 931 (144) Cc1 & 152 (52) Ad1 & 944 (150) Cc1 & $174(55)$ Ad1 \\
\hline
\end{tabular}

Uppercase letters represent treatments, lowercase letters represent sampling dates, and numbers represent grass cultivar. Entries that share a letter or number are not significantly different from one another at $\mathrm{P}<0.05$. 


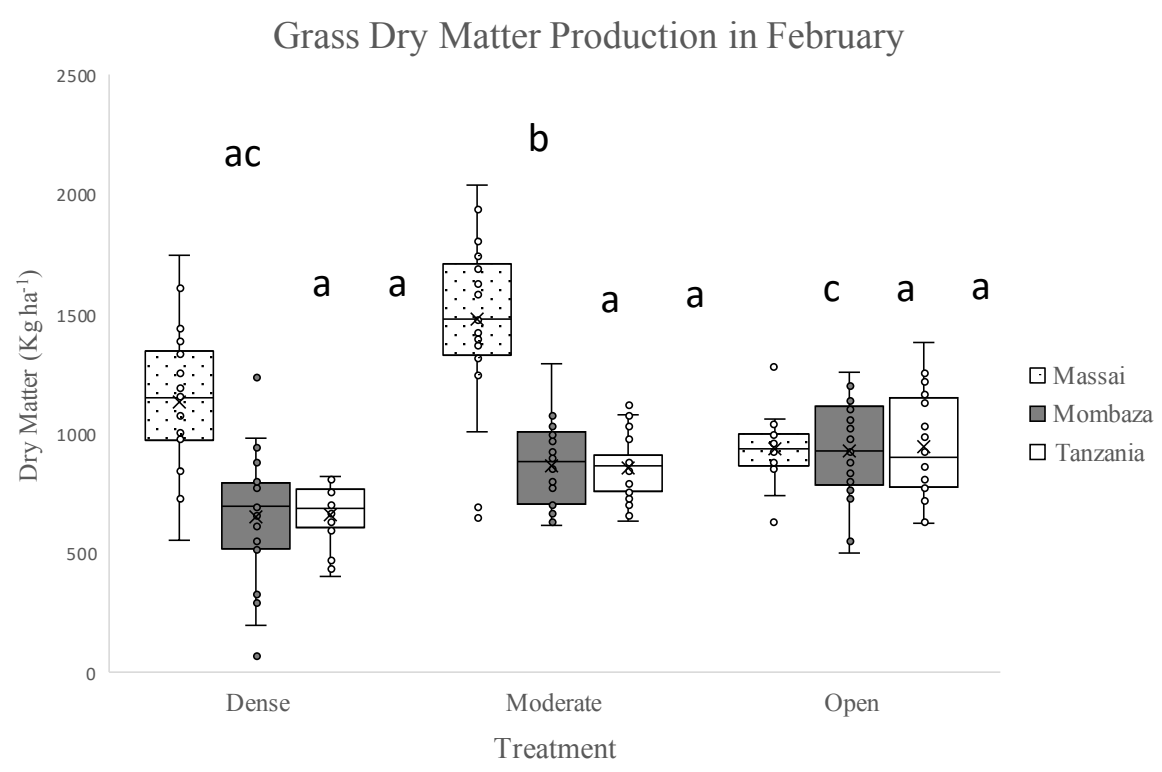

Fig. 5 Grass dry matter production for three cultivars of $M$. maximus in open (O), moderate (M), and dense (D) treatments for the month of February. Massai in M produced greater dry matter than both $\mathrm{D}$ and $\mathrm{O}$. Entries that share a letter are not significantly different from one another at $\mathrm{P}=0.05$.

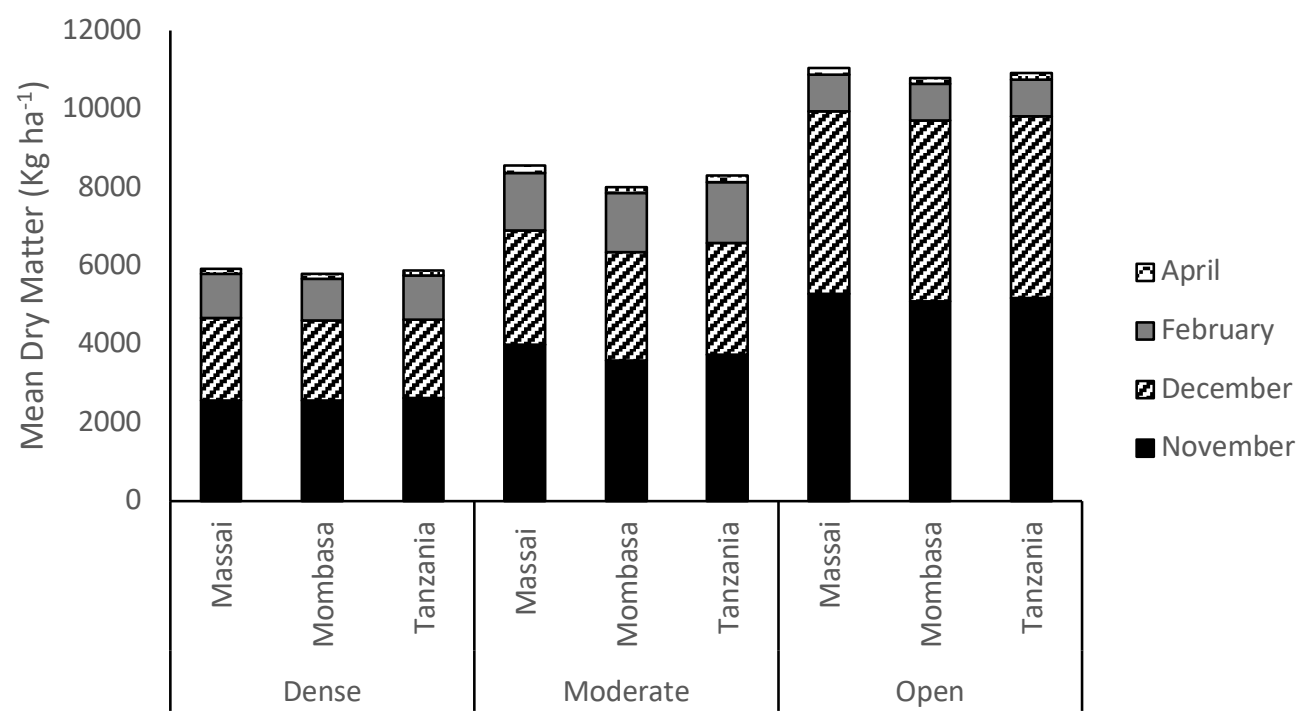

Fig. 6 Grass dry matter production for four sampling periods, two during the rainy season (November and December) and two during the dry season (February and April). 
Acid detergent fiber (ADF) was significantly different for treatment $(\mathrm{P}=0.0064)$, season $(\mathrm{P}=0.0001)$, and cultivar $(\mathrm{P}=0.0092)$. Grasses in $\mathrm{O}$ had significantly greater ADF concentrations than grasses in $\mathrm{M}(\mathrm{P}=0.0037)$ and $\mathrm{D}(\mathrm{P}=0.0048)$. Grasses sampled during the rainy season had higher ADF concentrations than grasses sampled during the dry season $(\mathrm{P}=0.0001)$. Massai had significantly greater ADF concentrations than Tanzania $(\mathrm{P}=0.0024)$, but did not differ from Mombaza $(\mathrm{P}=0.1068)$. There was a significant treatment*season interaction for NDF $(\mathrm{P}=0.0115)$. NDF of grasses growing in $\mathrm{D}$ and $\mathrm{M}$ was significantly greater during the rainy season, but did not differ between seasons in $\mathrm{O}(\mathrm{P}=0.2644)$.

Total Digestible Nutrients (TDN) and Relative Feed Value (RFV) were significantly affected by treatment $(\mathrm{P}=0.0059 ; \mathrm{P}=0.0051)$, season $(\mathrm{P}=0.0001 ; \mathrm{P}=$ 0.0001), and cultivar $(\mathrm{P}=0.0074 ; \mathrm{P}=0.0117)$. However, there were significant treatment*season interactions for both variables $(\mathrm{P}=0.0392 ; \mathrm{P}=0.0112) . \quad \mathrm{TDN}$ and RFV of grasses growing in D and $\mathrm{M}$ was significantly greater during the dry season, but did not differ between seasons in $\mathrm{O}(\mathrm{P}=0.0984 ; \mathrm{P}=0.1489)$. 
Table 5 Crude protein (CP, \%), acid detergent fiber (ADF, \%), neutral detergent fiber (NDF, \%), total digestible nutrients (TDN, \%), and relative feed value (RFV) least squares means for the M. megathyrsus cultivars Massai, Mombaza, and Tanzania during the dry and rainy (bold) seasons under open $(\mathrm{O})$, moderate $(\mathrm{M})$, and dense (D) tree cover. Entries that share a letter are not significantly different from one another at $\mathrm{P}<0.05$.

\begin{tabular}{|c|c|c|c|c|c|c|c|c|c|c|c|}
\hline & & Treatme & & ANOVA & & Cultivar & & ANOVA & \multicolumn{2}{|c|}{ Season } & ANOVA \\
\hline Variable & $\mathrm{O}$ & $\mathrm{M}$ & $\mathrm{D}$ & P-value & Massai & Mombasa & Tanzania & P-value & Dry & Wet & P-value \\
\hline $\begin{array}{l}\text { Crude } \\
\text { Protein (\%) }\end{array}$ & $7.8 \mathrm{~A}$ & $8.8 \mathrm{~B}$ & $9.6 \mathrm{~B}$ & 0.0138 & $8.3 a$ & $8.8 \mathrm{a}$ & $9.1 \mathrm{a}$ & 0.069 & $9.1 \mathrm{~A}$ & $8.4 \mathrm{~B}$ & 0.0129 \\
\hline $\operatorname{ADF}(\%)$ & $44.6 \mathrm{~A}$ & $40.3 \mathrm{~B}$ & $40.6 \mathrm{~B}$ & 0.0064 & $43.0 \mathrm{a}$ & $41.8 \mathrm{a}$ & $40.7 b$ & 0.0092 & $39.4 \mathrm{~A}$ & $44.2 \mathrm{~B}$ & $<.0001$ \\
\hline NDF $(\%)$ & $64.8 \mathrm{~A}$ & $61.8 \mathrm{~B}$ & $62.0 \mathrm{~B}$ & 0.0064 & $63.6 \mathrm{a}$ & $62.7 \mathrm{a}$ & $62.2 b$ & 0.0305 & $61.2 \mathrm{~A}$ & $64.5 \mathrm{~B}$ & $<.0001$ \\
\hline TDN (\%) & $57.1 \mathrm{~A}$ & $61.1 \mathrm{~B}$ & $60.9 \mathrm{~B}$ & 0.0059 & $58.6 \mathrm{a}$ & $59.6 a b$ & $60.8 b$ & 0.0074 & $62.0 \mathrm{~A}$ & $57.4 \mathrm{~B}$ & $<.0001$ \\
\hline RFV & 77.9A & $86.8 \mathrm{~B}$ & 86.3B & 0.0051 & $81.4 \mathrm{a}$ & $83.8 \mathrm{ab}$ & $85.9 b$ & 0.0117 & $88.7 \mathrm{~A}$ & $78.7 \mathrm{~B}$ & $<.0001$ \\
\hline
\end{tabular}




\section{Understory Light Environment}

Treatments $\mathrm{O}, \mathrm{M}$, and $\mathrm{D}$ all differed significantly with respect to understory light levels $(\mathrm{P}=0.005)$. In contrast, no significant difference was found between seasons $(\mathrm{P}=$ 0.272). Mean Global Site Factor values for the rainy season were 26.92, 48.09, and $98.53 \%$ for $\mathrm{D}, \mathrm{M}$, and $\mathrm{O}$, respectively, and $29.50,58.65$, and $99.13 \%$ for the dry season, respectively (Fig. 7). This corresponds to a $51.19 \%$ and $72.68 \%$ reduction in GSF for $\mathrm{M}$ and D during the wet season and a $40.84 \%$ and $70.24 \%$ reduction in GSF for M and D during the dry season.

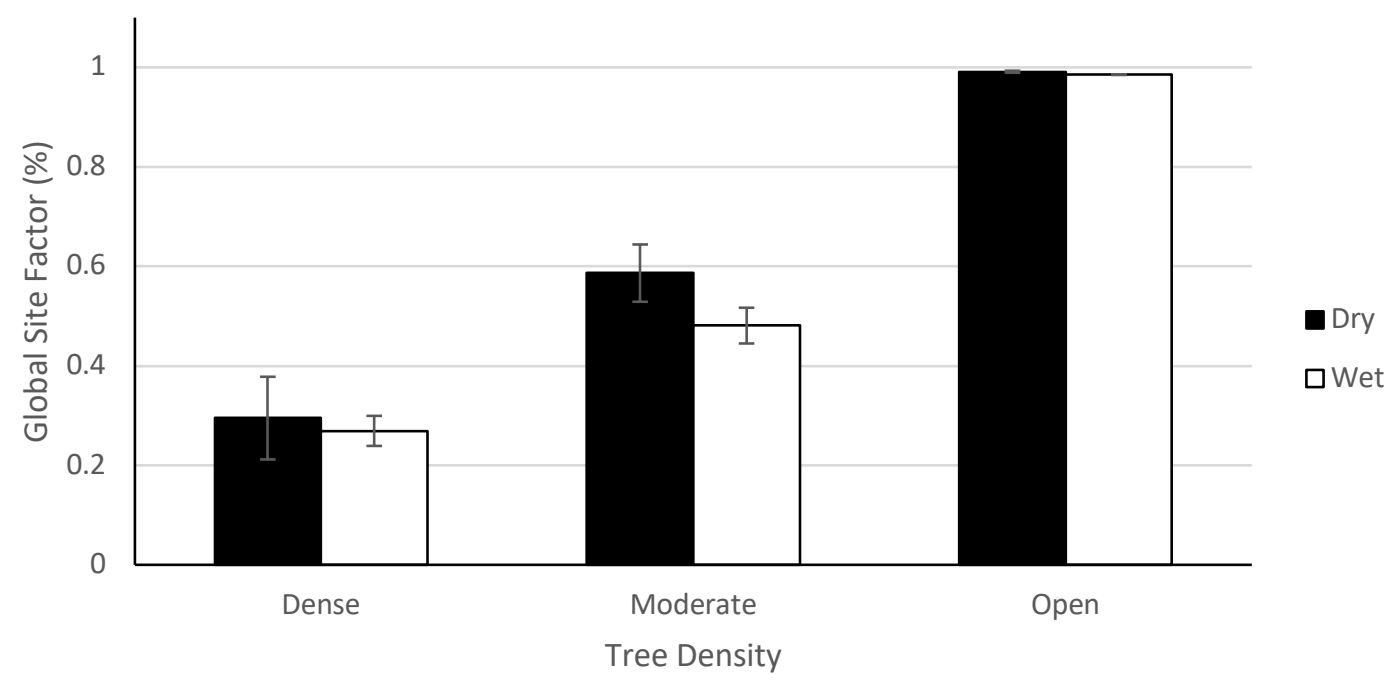

Fig. 7 Mean global site factor (GSF) measured under dense, moderate, and open tree coverage during the dry and wet seasons. Bars indicate $\pm \operatorname{SE}(n=9)$ 


\section{Soil Properties}

Analyses of soil chemical and physical properties demonstrated a relatively high soil fertility with an overall high base saturation $(\mathrm{BS})$ of $99.83 \%( \pm 0.28 \%)$, high cation exchange capacity $(\mathrm{CEC})$ of $26.0 \mathrm{cmol}(+) / \mathrm{kg}( \pm 3.44 \mathrm{cmol}(+) / \mathrm{kg})$, and a relatively low $\mathrm{pH}$ of $5.54( \pm 0.17)$. Total Carbon (TC) and Total Nitrogen $(\mathrm{TN})$ did not differ between treatments or years, and the overall C:N ratio was $10.82( \pm 2.74)$. Overall soil organic matter $(\mathrm{SOM})$ and bulk density was $3.22 \%( \pm 0.52)$ and $0.92 \mathrm{~g} / \mathrm{cm}^{3}\left( \pm 0.09 \mathrm{~g} / \mathrm{cm}^{3}\right)$, respectively.

No significant differences existed between treatments in regards to $\mathrm{CEC}, \mathrm{BS}$, SOM, TC, and TN, however, it is worth noting that TN levels in M and D were numerically greater than $\mathrm{O}(\mathrm{P}=0.2724)$. The soil $\mathrm{pH}$ differed significantly in all three treatments $(\mathrm{P}=0.0088)$, and there was a nearly significant increase between sampling periods (0.0806). Pairwise comparisons showed that $\mathrm{O}$ had significantly higher $\mathrm{pH}$ levels than $\mathrm{M}(\mathrm{P}=0.0150)$ and $\mathrm{D}(\mathrm{P}=0.0109)$. Bulk density differed between treatments $(\mathrm{P}=$ 0.001) and soil depth $(\mathrm{P}=0.0001)($ Fig. 8). O had significantly greater bulk density than $\mathrm{M}(\mathrm{P}=0.008)$ and $\mathrm{D}(\mathrm{P}=0.0009)$ while $\mathrm{M}$ was significantly greater than $\mathrm{D}(\mathrm{P}=0.0173)$. Bulk density increased with depth, with samples collected at 0-5 cm significantly less dense than those collected at $5-10 \mathrm{~cm}(\mathrm{P}=0.0012)$ and $10-15 \mathrm{~cm}(\mathrm{P}=0.0001)$.

Most soil nutrients did not differ significantly between treatments, however there were a few notable exceptions (Table 6). Exchangeable Potassium $\left(\mathrm{K}^{+}\right)$showed a marked increase in $\mathrm{O}$ when compared to both $\mathrm{M}$ and $\mathrm{D}(\mathrm{P}=0.0349)$. The least square means for dense, moderate and open treatments were 50.37, 51.16, and $66.63 \mathrm{mg} \mathrm{kg}^{-1}$, respectively, with $\mathrm{O}$ containing significantly more $\mathrm{K}^{+}$than $\mathrm{D}(\mathrm{P}=0.0445)$. Phosphorus $(\mathrm{P})$ increased 
non-significantly as tree density increased, with corresponding least square means of $1.807,2.01$, and $2.07 \mathrm{mg} \mathrm{kg}^{-1}$ for $\mathrm{O}, \mathrm{M}$, and $\mathrm{D}$, respectively.

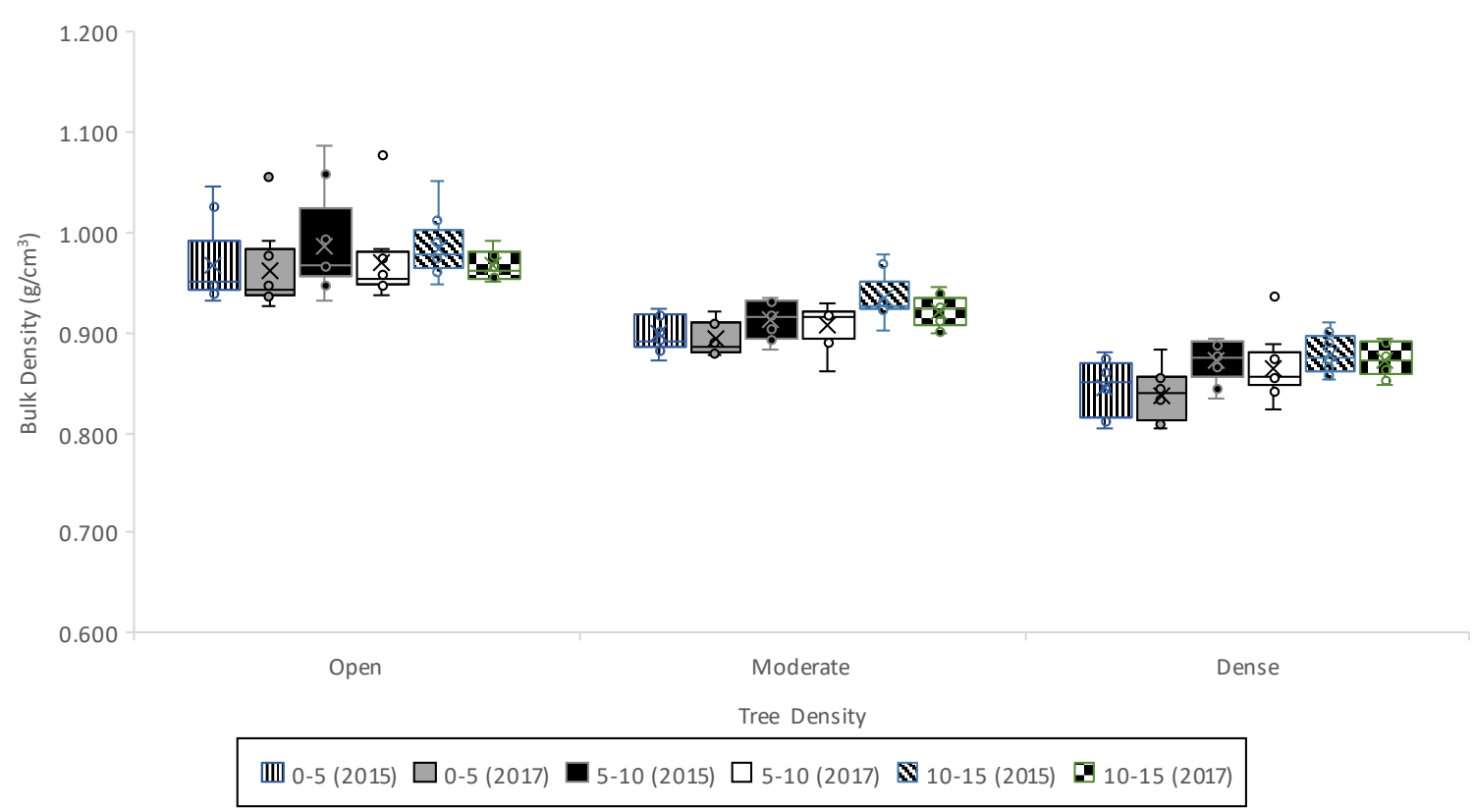

Fig. 8. Differences in bulk density $\left(\mathrm{g} \mathrm{cm}^{-3}\right)$ for three soil depths $(0-5,5-10$, and $10-15 \mathrm{~cm})$ in open (O), moderate (M), and dense (D) treatments for soils sampled in 2015 and 2017. Significant differences existed for depth and date in all three treatments. $n=9$

There was a significant difference in sampling period for $\mathrm{P}$, with 2017 concentrations greater than 2015 concentrations $(P=0.0194)$. CEC increased marginally as tree density decreased, with corresponding least square means of 26.48, 26.22, and $25.29 \mathrm{cmol}(+)$ $\mathrm{kg}^{-1}$, for $\mathrm{O}, \mathrm{M}$, and $\mathrm{D}$, respectively. 


\section{Soil Volumetric Water Content}

No significant differences existed between treatments for soil moisture $(\mathrm{P}=$ $0.1641)$, but there were clear differences between all six sampling periods $(\mathrm{P}=0.0001)$. Soil moisture increased with depth, with deeper soil horizons containing more moisture than shallow horizons $(\mathrm{P}=0.0001)$. The interaction between month and depth was highly significant $(\mathrm{P}=0.0001)$. Several patterns were observed between treatments at different months and depths that are worth noting (Fig. 9). During the dry season (January and March), soil moisture increased linearly with soil depth, with lower horizons retaining numerically more moisture than upper horizons. At the onset of the rainy season in May, the soil moisture was greatest in the upper and lower horizons and driest in the middle horizons. During the wettest parts of the year, the highest moisture levels were found in the middle horizons, creating quadratic curves. 
Table 6 Physical and chemical soil properties for soil collected in the rainy season of 2015 and 2017 within open (O), moderate (M), and dense (D) treatments. $\mathrm{n}=9$.

\begin{tabular}{|c|c|c|c|c|c|c|}
\hline & \multicolumn{2}{|c|}{ Open $(\mathrm{O})$} & \multicolumn{2}{|c|}{ Moderate (M) } & \multicolumn{2}{|c|}{ Dense (D) } \\
\hline & 2015 & 2017 & 2015 & 2017 & 2015 & 2017 \\
\hline Texture & Loam & Loam & Loam & Loam & Clay Loam & Clay Loam \\
\hline $\mathrm{pH}$ & $5.61 \mathrm{a}$ & $5.59 \mathrm{a}$ & $5.32 \mathrm{~b}$ & $5.35 \mathrm{~b}$ & $5.34 \mathrm{~b}$ & $5.33 \mathrm{~b}$ \\
\hline B.D. (g/cm3) & $0.98(0.04) \mathrm{a}$ & $0.97(0.04) \mathrm{a}$ & $0.92(0.02) b$ & $0.91(0.02) b$ & $0.87(0.03) \mathrm{c}$ & $0.86(0.03) \mathrm{c}$ \\
\hline TC $(\%)$ & $1.85(0.41) \mathrm{a}$ & $1.98(0.15) \mathrm{a}$ & $1.72(0.34) \mathrm{a}$ & $1.78(0.27) \mathrm{a}$ & $1.86(0.30) \mathrm{a}$ & $1.86(0.27) \mathrm{a}$ \\
\hline $\mathrm{TN}(\%)$ & $0.16(0.02) \mathrm{a}$ & $0.17(0.02) \mathrm{a}$ & $0.18(0.03) \mathrm{a}$ & $0.19(0.02) \mathrm{a}$ & $0.18(0.04) \mathrm{a}$ & $0.18(0.02) \mathrm{a}$ \\
\hline SOM (\%) & $3.23(0.71) \mathrm{a}$ & $3.47(0.25) \mathrm{a}$ & $3.01(0.60) \mathrm{a}$ & $3.11(0.47) \mathrm{a}$ & $3.25(0.52) \mathrm{a}$ & $3.25(0.48) \mathrm{a}$ \\
\hline $\begin{array}{l}\mathrm{CEC} \\
(\mathrm{cmol}(+) / \mathrm{kg})\end{array}$ & $26.31(3.02) \mathrm{a}$ & $26.64(3.37) \mathrm{a}$ & $25.21(4.86) \mathrm{a}$ & $27.23(2.63) \mathrm{a}$ & $24.57(2.71) \mathrm{a}$ & $26.01(3.83) \mathrm{a}$ \\
\hline BS $(\%)$ & $99.75(0.16) \mathrm{a}$ & $99.88(0.06) \mathrm{a}$ & $99.74(0.16) \mathrm{a}$ & $99.92(0.03) \mathrm{a}$ & $99.80(0.15) \mathrm{a}$ & $99.87(0.06) \mathrm{a}$ \\
\hline $\mathrm{P}(\mathrm{mg} / \mathrm{kg})$ & $1.79(0.40) \mathrm{aA}$ & $1.83(0.30) \mathrm{aA}$ & $1.92(0.30) \mathrm{aA}$ & $2.10(0.41) \mathrm{aB}$ & $1.84(0.34) \mathrm{aA}$ & $2.31(0.41) \mathrm{aB}$ \\
\hline $\mathrm{K}(\mathrm{mg} / \mathrm{kg})$ & 70.67 (8.59) a & $62.60(13.19) \mathrm{a}$ & $52.36(12.70) \mathrm{b}$ & $49.95(10.64) b$ & $52.24(9.61) \mathrm{b}$ & $48.51(10.18) b$ \\
\hline $\mathrm{Ca}(\mathrm{mg} / \mathrm{kg})$ & $5144.44(395.03) \mathrm{a}$ & $5167.67(286.49) \mathrm{a}$ & $5177.56(394.00) \mathrm{a}$ & $5153.11(338.80) \mathrm{a}$ & $5164.11(353.68) \mathrm{a}$ & $5104.67(389.61) \mathrm{a}$ \\
\hline $\mathrm{Mg}(\mathrm{mg} / \mathrm{kg})$ & $1420.67(67.57) \mathrm{a}$ & $1414(88.04) \mathrm{a}$ & $1369.11(100.92) \mathrm{a}$ & $1393.89(97.11) \mathrm{a}$ & $1384.44(59.06) \mathrm{a}$ & $1403.78(89.71) \mathrm{a}$ \\
\hline $\mathrm{Mn}(\mathrm{mg} / \mathrm{kg})$ & $54.60(6.18) \mathrm{a}$ & $54.79(7.64) \mathrm{a}$ & $54.36(4.60) \mathrm{a}$ & $58.44(4.07) \mathrm{a}$ & $54.60(6.18) \mathrm{a}$ & $49.93(9.40) \mathrm{a}$ \\
\hline $\mathrm{B}(\mathrm{mg} / \mathrm{kg})$ & $0.61(0.47) \mathrm{a}$ & $0.84(0.39) \mathrm{a}$ & $0.46(0.31) \mathrm{a}$ & $0.95(0.22) \mathrm{a}$ & $0.81(0.47) \mathrm{a}$ & $0.83(0.49) \mathrm{a}$ \\
\hline $\mathrm{Fe}(\mathrm{mg} / \mathrm{kg})$ & $146.83(11.55) \mathrm{a}$ & $151.66(12.57) \mathrm{a}$ & $153.68(5.84) \mathrm{a}$ & $154.02(9.72) \mathrm{a}$ & $154.09(11.13) \mathrm{a}$ & $149.75(10.76) \mathrm{a}$ \\
\hline $\mathrm{Zn}(\mathrm{mg} / \mathrm{kg})$ & $1.46(0.34) \mathrm{a}$ & $1.40(0.10) \mathrm{a}$ & $1.32(0.21) \mathrm{a}$ & $1.42(0.15) \mathrm{a}$ & $1.53(0.13) \mathrm{a}$ & $1.43(0.18) \mathrm{a}$ \\
\hline $\mathrm{Cu}(\mathrm{mg} / \mathrm{kg})$ & $4.59(0.71) \mathrm{a}$ & $4.54(0.49) \mathrm{a}$ & $4.23(0.49) \mathrm{a}$ & $4.21(0.40) \mathrm{a}$ & $4.04(0.53) \mathrm{a}$ & $4.25(0.59) \mathrm{a}$ \\
\hline
\end{tabular}

Data are means (standard error). Means sharing the same letter within a row are not significantly different from one another at $\mathrm{P}<0.05$. Lower case letters represent treatment differences; upper case letters represent differences between sampling dates. 

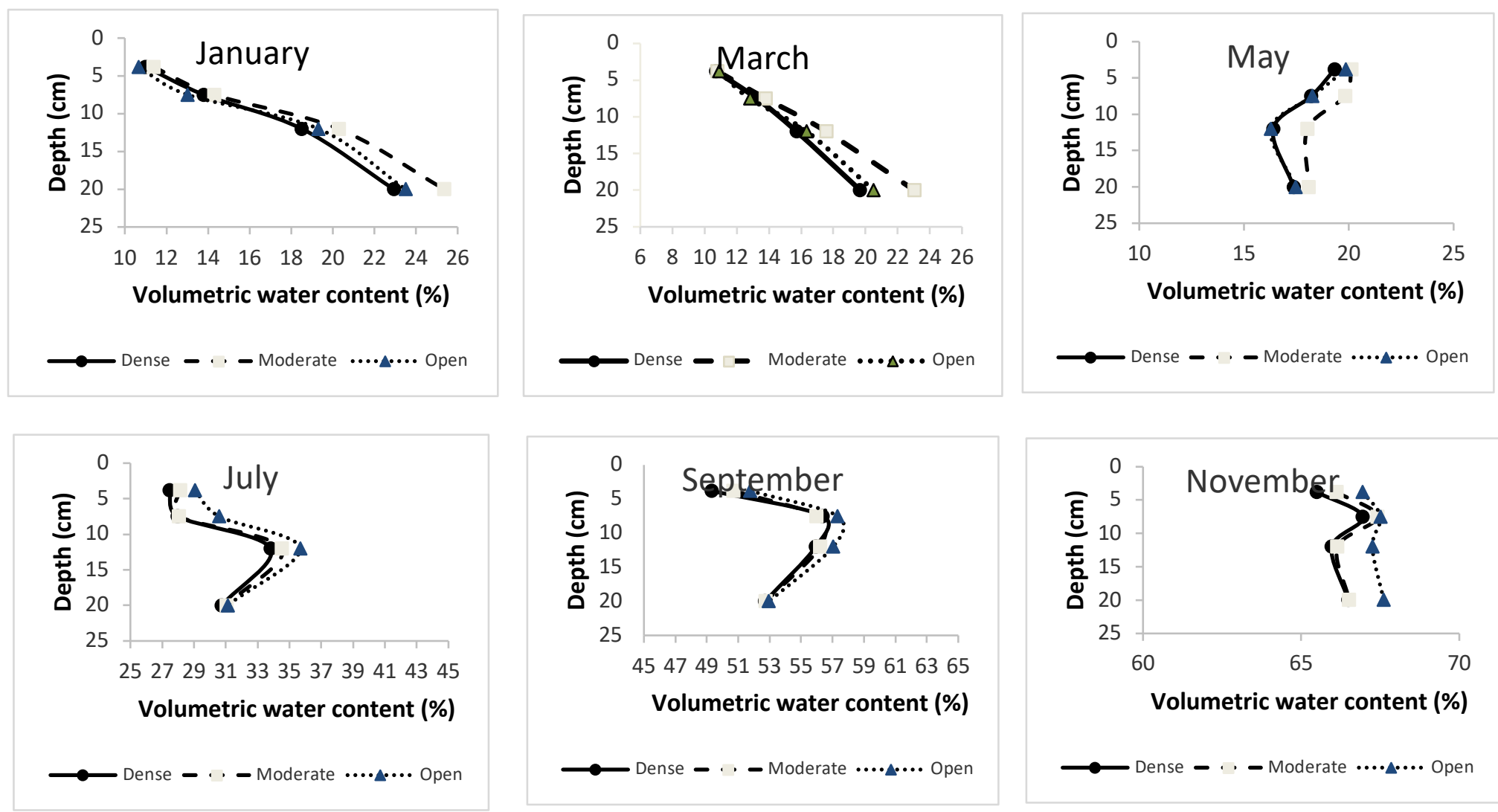

Fig. 9 Volumetric water content (\%) measured during 6 months in 2016 in open (O), moderate (M), and dense (D) treatments. Although no significant differences existed between treatments, several interesting patterns can be observed. X-axes are plotted on different scales for ease of visualization. 


\section{Discussion}

Forage Dry Matter Production

Treatment $\mathrm{O}$ produced significantly greater quantities of dry matter than $\mathrm{M}$ and $\mathrm{D}$ treatments. Forage yield declined by approximately 50\% in each treatment along the shade gradient, demonstrating that the $\mathrm{C} 4$ grass $M$. maximum and its cultivars respond vigorously to increased solar radiation. A widely accepted ecological tenet is that generally, as light intensity decreases, photosynthesis slows and herbage production decreases (Lin et al. 2001; Feldhake et al. 2010). This is especially true for C4 species, whose physiology allows for greater biomass accumulation per unit of photosynthetically active radiation (PAR) - or radiation use efficiency - than does the physiology of C3 species. However, research examining the effects of tree cover on the productivity of $M$. maximus has drawn mixed conclusions. Obispo et al. (2008) studied the growth of $M$. maximus in open pastures in northern Venezuela and found significantly greater quantities of dry matter production when compared with low, medium, and high tree densities. A study conducted in Veracruz, Mexico, concluded that there was a marginal forage reduction of $30 \%$ under a canopy of Gliricida sepium, but there was no evidence for a significant negative effect of tree canopy on $M$. maximus mediated by a reduction in PAR (Medinilla-Salinas et al. 2013). Similarly, Viáfara et al. (1997) reported neutral effects of tree cover when grown under a sparse canopy of the nitrogen-fixing tree Albizia saman during the dry season in a tropical dry forest. Several studies have demonstrated that under certain conditions, moderate shading can provide optimal conditions for grass growth and quality (Belsky 1994; Ibrahim et al. 2007; DeBruyne et al. 2011; Orefice et al. 2016). Hernández and Guenni (2008) concluded that M. maximus grasses benefited 
from a compensatory effect from trees that increased soil humidity and improved total forage biomass. Andrade et al. (2004) found that Massai grass growing under artificial shade reached its highest dry matter accumulation rate under $30 \%$ shade cover in both the rainy and dry seasons. The $48 \%$ reduction in basal area realized for the $\mathrm{M}$ treatment in our study allowed for as much as $50 \%$ shading in some areas, evidently too much shade for optimal production of this species. One important detail to note from our study is that when the trees were planted in 2005, they were planted on contour lines, resulting in plantations that look more like natural forests and less like evenly-spaced plantations. This resulted in a patchy distribution of sun flecks reaching the ground, with some areas receiving no radiation and others receiving much more. Planting trees more evenly across the landscape, at lower densities, could increase the overall forage yield.

Reported dry matter yields for M. maximus and its cultivars vary widely, with open pasture wet season estimates ranging from 2,400 $\mathrm{kg} \mathrm{ha}^{-1}$ (Brâncio et al. 2003) to as much as $20,900 \mathrm{~kg} \mathrm{ha}^{-1}$ for open pastures fertilized with 150 to $200 \mathrm{~kg} \mathrm{ha}^{-1}$ of nitrogen (Fernandes et al. 2014). These estimates depend greatly on site-specific climatic and edaphic conditions, management, and sampling protocol; thus, comparisons should be made cautiously. Our average open pasture wet season estimates for Massai, Mombaza, and Tanzania were 4972.76 $\pm 343.08,4855.05 \pm 252.01$, and $4901.92 \pm 288.59 \mathrm{~kg} \mathrm{ha}^{-1}$, respectively. Unsurprisingly, pasture productivity differed significantly between the wet and dry seasons, with the wet season producing on average 81,89 , and $88.6 \%$ more forage than the dry season for Massai, Mombaza, and Tanzania, respectively.

Our finding that Massai produced significantly more dry matter than Mombaza and Tanzania is not dissimilar from data presented elsewhere. Correa et al. (1998) 
reported dry matter weights of 4,000,3,600, and 3,300 $\mathrm{kg} \mathrm{ha}^{-1}$ at a cutting interval of 35 days for Massai, Mombaza, and Tanzania, respectively. Fernandes and colleagues (2014) evaluated the growth of 24 fertilized M. maximus genotypes over a two-year period and reported average dry matter yields of 16,750, 15,650, and 13,900 $\mathrm{kg} \mathrm{ha}^{-1}$ for Massai, Mombasa, and Tanzania, respectively. When different harvest periods and plant components are analyzed, cultivar comparisons are not as simple. Braga and colleagues (2014) found that Mombasa produced $855 \mathrm{~kg} \mathrm{ha}^{-1}$ more dry matter than Massai during the establishment phase, but produced $1427 \mathrm{~kg} \mathrm{ha}^{-1}$ less dry matter during the maintenance phase. In another study comparing the three varieties, Brâncio et al. (2003) reported the highest density of dry matter and leaf:stem ratio for Massai, but also found that it had the lowest leaf:dead material ratio. In that same study, Mombaza presented the poorest results, with the lowest leaf:stem ratio.

Although we did not find a significant difference in dry matter production between Mombaza and Tanzania, Tanzania consistently produced marginally greater dry matter than Mombaza. This finding contradicts the results of several other studies that conclude that Mombaza is more productive than Tanzania (Cecato et al. 2000). SantiagoHernández et al. (2016) examined the growth of Mombaza and Tanzania growing in Melia azedarach L. plantations and found that Mombaza produced more forage biomass than Tanzania, with reported mean values of 4,683 and 4,279 $\mathrm{kg} \mathrm{ha}^{-1}$ harvest $^{-1}$, respectively. They also reported that total forage biomass was significantly greater during the rainy season than during the non-rainy season and that biomass declined significantly by $44 \%$ under full shade (1000 trees ha- 1 at $11.0 \mathrm{~cm}$ mean $\mathrm{DBH})$. 
Tanzania consistently produced numerically greater quantities of dry matter than Mombaza in all three treatments, so it is not likely due to differences in shade tolerance, but rather to some other factor. It is known that Mombaza and Tanzania are more demanding than Massai in terms of soil fertility (Brâncio et al. 2003) and it could be that Mombaza is even more nutrient-demanding than Tanzania. None of the treatments were ever fertilized over the course of the study, so the grasses had to rely solely on soil nutrient reserves. This is, however, speculation, and needs further research for confirmation.

Forage Nutritive Value

Our hypothesis predicting increased levels of CP in the shade was supported, indicating that trees may provide an added benefit to forage nutritive quality. Increased $\mathrm{CP}$ values for forages growing under shade is commonly reported in the literature (Lin et al. 1998, 2001; Feldhake et al. 2010; Neel and Belesky 2017; Orefice et al. 2017) and is likely due to adaptive mechanisms and changes in plant physiology such as elongation of the cell wall (Kephart and Buxton 1993), an increase in specific leaf area, and a decrease in the root:shoot ratio (Paciullo et al. 2017). The presence of nitrogen-fixing trees may also indirectly increase $\mathrm{CP}$ levels in forages through leaf decomposition, root exudation, and direct nutrient exchange (Sierra and Nygren 2006; Sierra et al. 2007; Jalonen et al. $\left.2009^{\mathrm{a}}\right)$.

In our study, the highest $\mathrm{CP}$ values ranged between 7.78 and 8.17 for the $\mathrm{O}$ treatment, 8.92 and 10.16 for the $\mathrm{M}$ treatment, and 9.12 and 10.65 for the $\mathrm{D}$ treatment. Generally, forage $\mathrm{CP}$ values between 11 and $12 \%$ are recommended for good 
performance of beef cattle, and values become critical when they drop below 7\% (Wright et al. 2010). A number of authors have reported much higher CP values for M. maximus. Viáfara and colleagues (1997) found CP values as high as 18\% in Guinea grass growing under intermediate shade cover during the dry season. Obispo et al. (2008) reported CP values between 12 and $13.2 \%$ for Guinea grass growing under trees and values as high as $39.2 \% \mathrm{CP}$ were reported for Guinea grass growing with the nitrogen-fixing tree Gliricidia sepium (Medinilla-Salinas et al. 2013).

From the ADF, NDF, TDN, and RFV results, we conclude that forage nutritive quality increased with increasing shade levels. Pooled mean ADF values for $\mathrm{O}, \mathrm{M}$, and $\mathrm{D}$ treatments were $43.20,37.60$, and $37.55 \%$, respectively, while pooled NDF values for O, $\mathrm{M}$, and D treatments were $64.01,59.86$, and $59.57 \%$, respectively. In general, ADF and NDF show a high negative correlation with TDN and RFV, due to the presence of greater quantities of lignin and cellulose, which ultimately degrade the forage dry matter digestibility. Typically, ADF and NDF concentrations of most forage species are either increased or unaffected by shade (Ladyman et al. 2003; Kallenbach et al. 2006; Sousa et al. 2010; Paciullo et al. 2014; Neel and Belesky 2015). However, there are a number of studies that report decreasing values with increased levels of shade (Obispo et al. 2008; Medinilla-Salinas et al. 2013). The lower ADF and NDF values reported here could be due to grass developing more elongated schlerenchyma under shaded conditions (Paciullo et al. 2017).

We found that Massai had significantly greater ADF and NDF concentrations than Tanzania, but not Mombaza. This coincides with that reported by Brâncio et al. (2002), who claimed that Massai was a relatively low nutritive cultivar, with ADF values 
around $44.2 \%$, slightly higher than the $43.1 \%$ reported for Mombasa and Tanzania. Machado et al. (1998) claimed that Massai had above average ADF and NDF when compared to that of Mombasa and Tanzania, with respective values of 37.9, 37.1, and $36.0 \%$ for ADF and $75.5,74.3$, and $73.2 \%$ for NDF. This may reduce dry matter digestibility and animal productivity in Massai pastures when compared to other Megathyrsus cultivars (Brâncio et al. 2002; Euclides et al. 2014; Paciullo et al. 2017).

Season had a significant effect on all nutritive value measurements, with grasses sampled during the dry season showing higher CP, TDN, RFV, and lower ADF and NDF values than those sampled during the rainy season. This finding is supported by SantiagoHernández et al. (2016), who found that overall, grass nutritional quality increased during the non-rainy season and under shade. Additionally, Wilson (1983) showed grasses that were drought-stressed tended to have higher in-vitro dry matter digestibility and overall nutritional quality. All three cultivars responded similarly to nutritive quality changes in regards to season, without any major differences between the three varieties.

\section{Soil Properties}

Certain locations on the Azuero Peninsula are known to have relatively fertile soils for Panama (Wishnie et al. 2007; Breugel et al. 2011; Griscom et al. 2011). Results of this research demonstrating high BS and relatively high CEC values corroborate this; however, overall low SOM and concentrations of essential nutrients such as $\mathrm{P}$ and $\mathrm{N}$ are indicative of a history of soil degradation, likely due to decades of extensive cattle ranching. Our hypothesis predicting significantly higher fertility levels under increasing tree cover was not supported, despite the presence of $\mathrm{N}$-fixing trees in $\mathrm{M}$ and $\mathrm{D}$. 
The overall $\mathrm{C}: \mathrm{N}$ ratio was similar to that which has been previously reported from grasslands and forests in Panama (Paul and Weber 2016) but neither TN nor TC differed significantly among treatments or years. This differs from the findings of Krieb and Pacala (2012), who compared soils collected from pasture and reforested areas on the Azuero Peninsula and found that both TC and TN were significantly greater under tree cover than in open pasture. Macedo et al. (2008) compared the soil fertility of an open pasture dominated by Guinea grass (M. maximus) with a thirteen-year old plantation dominated by fast-growing leguminous nitrogen-fixing trees and found that $\mathrm{C}$ and $\mathrm{N}$ stocks in the plantation recovered to levels found in nearby surrounding forest. Although significant differences did not exist between treatments, the authors concluded that reforested areas were in the process of recovery. Alternatively, our finding is supported by the work of Sandoval-Pérez et al. (2009) who found that C and N variables did not differ between primary forests, 26-year old pastures, and 26-year old secondary forests in Jalisco, Mexico.

Silvopastures, being a combination of both trees and grasses are inherently complex and there is still much to learn about how system components cycle and utilize nutrients. $\mathrm{C}_{4}$ grasses and perennial woody species have different physiologies and have been shown to cycle nutrients differently. Reiners et al. (1994) suggested that reforested areas may not show an increase in total $\mathrm{C}$ or $\mathrm{N}$ because pasture grasses remaining on the land can contain reasonable amounts of carbon. In this same study, the authors reported greater nitrogen mineralization rates in forests than in open pastures, a finding that has been corroborated by other authors (Neill et al. 1995; Vitousek 2013). In our study, TN 
did increase marginally with increasing levels of shade, so it is possible that with time, TN could eventually reach levels that are significantly different from open pasture.

The most drastic difference found between treatments in regards to the major cations was for exchangeable $\mathrm{K}^{+}$. Open pastures contained significantly greater concentrations of $\mathrm{K}^{+}$than either of the two forested treatments. This finding corroborates results presented by other authors, who studied changes in soil chemistry after conversion from forest to pasture (Reiners et al. 1994; Krieb and Pacala 2012), but contrasts with the results of other studies (Belsky et al. 1989; Casals et al. 2013). It is likely that $\mathrm{K}^{+}$is inextricably linked to the acidity of the soil, with greater $\mathrm{K}^{+}$concentrations occurring in less acidic environments due to greater exchange site availability at the soil particle surface. However, if this were the sole reason for such a difference, one would expect higher concentrations of alternative exchangeable bases in the open pasture, which we did not observe. It could be that relatively young, fast-growing tree species are highly demanding of $\mathrm{K}^{+}$in the dry tropical forest or that pasture grasses are more $\mathrm{K}^{+}$-efficient than woody perennials (Krieb and Pacala 2012).

The literature is contradictory in terms of the major base cations and their relationship to tree cover. Studies have shown that nutrients can both increase and decrease with tree cover and direct comparisons are of limited use due to the existence of a wide range of soil types, research methodologies, tree densities, and species compositions (Belsky et al. 1989). Although relatively low, concentrations of $\mathrm{P}$ increased significantly in our study from 2015 to 2017 in the M and D treatments. These results complement the findings of Casals and colleagues (2013), who found that the presence of scattered trees in seasonally dry tropical pastures in Nicaragua increased overall plant 
available P, among other soil fertility parameters. Similarly, Krieb and Pacala (2012) reported higher cation concentrations in older reforested plots.

Soil $\mathrm{pH}$ was significantly lower in the $\mathrm{M}$ and $\mathrm{D}$ treatments than it was in the $\mathrm{O}$ treatment. This is in agreement with other studies (Reiners et al. 1994; Sandoval-Pérez et al. 2009) that report increasing acidity under trees, but it differs from the findings of Krieb and Pacala (2012), who reported the opposite trend for soils collected on the Azuero Peninsula. Reiners et al. (1994) explained that grasses cycle base cations more rapidly and generate fewer and less persistent organic acids than do forests. This, along with a long cultural history of burning pastures likely contribute to the lower $\mathrm{pH}$ observed in the $\mathrm{O}$ treatment. Burning pastures creates a base-rich ash deposition, perpetuating long-lasting increases in $\mathrm{pH}$ and base saturation (Reiners et al. 1994). Historically, all treatments were seasonally burned. Burning was discontinued in the plantation in 2005 upon tree planting while it was continued yearly in the open treatment to facilitate the establishment of maize. Frequent and periodic pasture burning may also be a reason for the aforementioned increases in exchangeable $\mathrm{K}$ and marginal increases in $\mathrm{CEC}$ in the $\mathrm{O}$ treatment.

Our results showing significant differences between treatments and soil depth for bulk density are widely supported in the literature (Belsky 1994; Staley et al. 2008; Orefice et al. 2017). Bulk density decrease is one of the most commonly recorded improvements in soil quality after reforestation of pastures (Li and Shao 2006), as tree roots create important macropores in the soil (Sandström 1998), and the removal of livestock often reduces compaction (Sharrow 2007). Our findings are similar to those presented by Orefice and colleagues (2017), who found that bulk density increased 
significantly in open pasture and silvopasture and differed significantly from forest after two years of management. Bulk density also has important implications for soil moisture, in that it directly influences the rate and conversion of precipitation into plant available soil water and other physical properties such as porosity and hydraulic conductivity ( $\mathrm{Li}$ and Shao 2006).

\section{Soil Volumetric Water Content}

As expected, there were strong differences between sampling periods, reflecting variable precipitation throughout the year. Our finding that soil moisture increased with depth did not come as a surprise, as superficial soil layers are directly exposed to atmospheric fluctuations, such as radiation, heat, wind, evaporation, litterfall, and bioturbation. Our hypothesis predicting greater moisture availability in the $\mathrm{M}$ treatment during the dry season was partially supported. During the month of February, Massai showed strong resilience to drought in moderate shade, accumulating more biomass than that of Tanzania and Mombasa for both $\mathrm{O}$ and D treatments (Fig. 6). Soil moisture levels have been shown to directly affect grass productivity and longevity in seasonally dry areas. In a study examining the growth of Massai under four artificial shade levels, Andrade et al. (2004) claimed that shaded treatments alleviated water stress during the dry period and decreased the seasonality of production of the forage grass. As shade level increased, the difference between the accumulation rate of dry matter between the wet and dry seasons decreased.

We noted several interesting patterns that are worth discussing. In the two driest months (January and March), all three treatments varied little in soil moisture at the 
shallowest depths, but showed greater differences at the deepest depth (Fig. 7). In January, the M treatment had 2.42 and $1.86 \%$ more soil moisture than the $\mathrm{D}$ and $\mathrm{O}$ treatments at the $20 \mathrm{~cm}$ depth, respectively. In March, the $M$ treatment had 3.36 and $2.53 \%$ more soil moisture, respectively, and in May, the $\mathrm{M}$ treatment had 0.71 and $0.61 \%$ more soil moisture than the $\mathrm{D}$ and $\mathrm{O}$ treatments, respectively. The $\mathrm{M}$ treatment also showed numerical differences at the $12 \mathrm{~cm}$ depth, with 1.64 and $1.76 \%$ more moisture than the $\mathrm{D}$ and $\mathrm{O}$ treatments at that depth, respectively. During the rainy months (July, September, November), soil moisture was marginally, yet consistently greater in the $\mathrm{O}$ treatment (Fig. 6). These differences are small, but biologically, in an environment where water is severely limited, they may prove to be important for plant production and longevity.

Hydrologic implications of changes in vegetation cover are controversial, and results vary widely with changing edaphic and climatic factors. A number of studies have shown strongly reduced streamflow and groundwater recharge after afforestation and reforestation has been scrutinized because of this (Calder et al. 2004; Farley et al. 2005). Some authors have touted the hydraulic benefits of planting trees and have encouraged their use in seasonally dry ranching systems to mitigate the effects of harsh seasonality (Vetaas 1992; Hernández and Guenni 2008). It cannot go without saying, however, that the hydraulic effects of trees are always site-specific, and there are circumstances where trees have a neutral (DeBruyne et al. 2011) or even negative effect (Wilson 1998) on water supply.

The soils identified in this study are finer textured and heavily-weathered, requiring continual organic input from leaves and bioturbation from roots to maintain 
their structure and porosity (Malmer et al. 2010). When removed of vegetation, these soils become vulnerable to erosion and land degradation when exposed to intense rainfall, which ultimately results in reduced rates of infiltration, less groundwater recharge, and a loss of dry-season water sources (Sandström 1998). Immediately after harvest, water runs off the surface and results in short-term increased water yield, but unlike in temperate regions, semi-arid and arid regions experience little piston-flow recharge and much of the moist soil water returns to the atmosphere by evaporation (Bruijnzeel 2004). When this is coupled with increased compaction from tree harvesting skidders, roads, and ranching activities, infiltration is even further limited. Under these conditions, macropores created by tree roots become the only active mechanism for soil water recharge.

Although not significant, our results demonstrating marginally lower soil moisture concentrations for the $\mathrm{D}$ and $\mathrm{O}$ treatments indicate that soil moisture may be dependent on tree density. It could be that there is an optimal number of trees $\mathrm{ha}^{-1}$ to maximize soil water storage, beyond which they begin to deplete storage. This idea, known as optimal tree cover theory, was tested by Ilstedt et al. (2016) in a seasonally dry agroforestry parkland in West Africa. Using groundwater budgets calibrated with measurements of drainage and transpiration, the authors found that $16 \%$ of the annual rainfall percolating to a depth of $1.5 \mathrm{~m}$ occurred around the edge of the tree canopy. This number was reduced to $1.3 \%$ in open areas, $37 \mathrm{~m}$ away from the nearest tree. They also found that in open areas, the date at which the first draining water was recorded was positively related to the distance of the nearest tree, with areas closest to trees receiving water about 30 days earlier than those located furthest away. Based on these results, the authors recommended a maximum density of 16 trees $\mathrm{ha}^{-1}$ to maximize soil water recharge for 
this site, however, if crowns are actively pruned groundwater recharge may remain positive for up to as many as 60 trees ha-1 (Ilstedt et al. 2016).

The marginally greater amounts of moisture in deeper soil layers under moderate tree cover observed in this study during the driest months could be explained by mechanisms similar to those described by Ilstedt et al. (2007). The main positive hydraulic benefit of trees is increased infiltration rates, especially in soils that are prone to surface run-off. Trees that shed their leaves during the dry season, like the majority of those studied here, can provide further enhancement for groundwater recharge by contributing organic matter to the soil via litterfall and reducing transpiration rates during the dry season. Ilstedt et al. (2016) recorded no percolation under the canopy, presumably due to interception and transpiration, but drainage improved directly at the edge of the canopy. Maximizing the canopy-edge interface could positively affect groundwater recharge. In fact, Ilstedt and colleagues (2007) simulated different canopy cover densities and found that the largest tree to tree distance achieved 35\% higher groundwater recharge than the average random distribution.

Another explanation for marginally lower moisture values in the $\mathrm{O}$ treatment during the dry season could be due to evapotranspiration caused by heavy winds and high temperatures (Lin 2010). Grasses in the M and D treatments were provided with shade that has been shown to lower average surface temperatures by as much as $3^{\circ} \mathrm{C}$ and evapotranspiration by $1.8 \mathrm{~mm} \mathrm{day}^{-1}$ in the tropics (Murgueitio et al. 2011, CIPAV unpublished data). Trees also provide a barrier from the harsh winds experienced on the Peninsula, which experiences average wind gusts of $36.7 \mathrm{~km} \mathrm{hour}^{-1}$ during the month of February (worldweatheronline.com). Our result showing that soil moisture was 
marginally, yet consistently greater in the $\mathrm{O}$ treatment during the rainy season can be explained best by a lack of canopy interception. During the rainy season, trees in the M and D treatments with fully developed leaves likely intercepted raindrops, preventing them from reaching the forest floor. Contrarily, in the $\mathrm{O}$ treatment, raindrops fell directly on top of grasses and the soil surface.

\section{Conclusions}

It is evident that grass productivity and nutritive quality are influenced by a plethora of factors, including but not limited to climatic, edaphic, structural, and ecological factors, along with past and current land use management strategies. This study confirmed that all three cultivars of $M$. maximus responded vigorously to sunlight, significantly increasing dry matter production with increased levels of solar radiation. We also confirmed that the cultivar Massai produced significantly greater amounts of forage than Mombasa, but not for Tanzania. Interestingly, Massai showed the greatest tolerance to drought, producing the most dry matter forage accumulation in the early part of the dry season, but only for areas with moderate $(\mathrm{M})$ tree density. This suggests that, during the early part of the dry season, microclimatic conditions for grass growth are optimal in areas with moderate densities of trees. Drought conditions cause grasses to mature earlier, becoming inadequate to meet demands for animal production. This observed extension of the growing season, coupled with thermal stress reduction provided by moderate tree cover (McIlvain and Shoop 1971; McArthur 1991; Murgueitio et al. 2011), could result in improved animal weight gains between the months of January and April at this study site. The use silvopasture during times of the year when it may be preferable to open 
pasture has been recommended in combination with traditional systems for temperate ranching. Kallenbach (2009) showed that cattle provided access to silvopasture retained greater weights and weaned heavier calves than those in the open pasture. Research is needed on animal productivity in silvopasture studied here to determine if similar benefits can be realized in the tropics.

It is critical to note that productive swards of M. maximus will not be achieved without proper nutrient and livestock management, regardless of overstory tree density. Tropical grass growth is severely limited by N and P deficiency (Silveira et al. 2015), and results presented here show no indication - at least in the short-term - of beneficial changes in soil chemical properties due to higher tree densities. In fact, the highest soil fertility existed in the $\mathrm{O}$ treatment, likely due to historical burning and fertilizing that did not take place on the tree plantation. To increase overall forage production, nutritional value and overall livestock performance at the IDB Forestal ranch, we recommend either annual inputs through responsible $\mathrm{N}$ and $\mathrm{P}$ fertilization or the incorporation of nitrogenfixing legumes such as Arachis pintoi and Pueraria phaseoloides (Andrade et al. 2004). We also recommend the continued use of managed intensive rotational grazing (MIRG), with paddock occupancy determined by a sward height of $70 \mathrm{~cm}$ (Euclides et al. 2014) as opposed to a fixed-length rest period. All M. maximus cultivars have a tendency towards excessive growth of stems when there is no control of sward height (Da Silva et al. 2009). Use of target sward heights in pre- and post-grazing helps to control the growth of stems that can be harmful to intake and cattle performance (Benvenutti et al. 2008).

Results from this study are intriguing, encouraging further research on the topic. However, these results should be interpreted with caution due to several limitations that 
we could not avoid. Since the establishment of the plantation 15 years ago, land use and management of the $\mathrm{O}$ treatment has been different than that of the $\mathrm{M}$ and $\mathrm{D}$ treatments, resulting in different soil chemical and physical characteristics. We sampled soils previous to the study for all treatments and found that differences existed only for $\mathrm{pH}$, bulk density, and $\mathrm{K}^{+}$, with similar values for all other nutrients. This compromises the homogeneity of all three treatments and makes it difficult to conclude that differences observed were due to the treatment and not to some other confounding variable. The use of adequate sample sizes and the utilization of a mixed model to account for random variation in the study were measures we took to account for these differences, decrease overall variation, and achieve replicable results. Nonetheless, caution should be heeded in their interpretation and they most certainly should not be extrapolated and applied to silvopastoral systems with different climates, soils, and ecological communities. Further research is needed to corroborate the results presented here, with greater emphasis placed on sparse tree canopies (10-30\% shade) and how they affect animal production.

With climate change worsening and drought conditions becoming more prevalent and pervasive on the Azuero Peninsula, the integration of trees into ranching systems may serve as an important buffer and defense against severe losses in production. The same trees that ranchers in Los Santos once regarded as incompatible with cattle production may, in fact today, be an indispensable component during the dry season. 


\title{
Chapter 3
}

\section{Can Fodder Shrubs Act as Fertilizer? The Neighborhood Effect of Shrubs on Soil Fertility, Pasture Production, and Albizia saman Growth and Survival in Simulated Silvopastures in Panama}

\author{
Abstract \\ The nutrients nitrogen $(\mathrm{N})$ and phosphorus $(\mathrm{P})$ limit the growth of pasture plants in many terrestrial ecosystems, and in \\ developing countries, the use of fertilizers by small landholding farmers is often not economically feasible. Fertilizer \\ trees are trees that can fix atmospherically available $\mathrm{N}$ and effectively cycle major nutrients. The use of fertilizer trees \\ in ranching systems could serve to intensify agricultural production while maximizing conservation benefits. We \\ examined the neighborhood effects of the fertilizer shrubs Leucaena leucocephala and Tithonia diversifolia on the \\ native tree species $A$. saman and exotic grass Megathyrus maximumus var. Massai. We hypothesized that fertilizer trees \\ would significantly increase important soil fertility indicators such as Cation Exchange Capacity (CEC), soil organic \\ matter (SOM), major cations $\mathrm{Ca}, \mathrm{K}$, and $\mathrm{Mg}$, and plant available $\mathrm{N}$ and $\mathrm{P}$ and decrease bulk density. We expected water \\ availability to be limited, particularly during the dry season and in plots with shrubs. We also hypothesized that shrub \\ plots would significantly increase the DM productivity of Massai due to nutrient provisioning. Lastly, we hypothesized \\ that $A$. saman saplings surrounded by shrubs would grow significantly faster and have higher survival rates than those \\ planted without neighbors. Two years after planting, bulk density was significantly reduced in all plots except for C, \\ where the soil was left bare. There were significant increases in $\mathrm{Ca}, \mathrm{K}, \mathrm{CEC}$ and SOM in plots that included shrubs \\ throughout the course of the study. Additionally, plant available N and P increased in plots containing L. leucocephala \\ and $T$. diversifolia shrubs. There were no planting regime effects on soil water availability and $A$. saman sapling \\ moisture stress. Massai grass DM production showed a marginally significant positive response to the association with \\ L. leucocephala, and although not significant, was reduced in the presence of $T$. diversifolia. A. saman growth and \\ survival was not affected by planting regime. cumulative forage production in plots with shrubs provided on average 10 \\ $\%$ more forage than plots without shrubs during the dry season. Although the findings presented here indicate \\ facilitation by $A$. saman and L. leucocephala on surrounding pasture growth, plantations are still in their early stages, \\ and results should be heeded with caution. Combining grasses with shrubs and trees creates three distinct foraging \\ layers that can help mitigate forage losses during severe droughts and provide nutritional diversity to livestock.
}

Key Words: Silvopasture, fodder shrubs, soil fertility, dry matter production, seedling growth 


\section{Introduction}

\section{The Green Revolution Problem}

In many terrestrial ecosystems, water and nutrients, especially nitrogen $(\mathrm{N})$ and phosphorus (P), limit the growth of plants. Consequently, these limiting factors also pose as major constraints to agricultural production (Matson 1997). Changing land-use practices have enabled commodity crop harvests to double in the past four decades, largely due to production gains resulting from "Green Revolution" technologies, including high-yielding cultivars, chemical fertilizers and pesticides, and mechanization and irrigation (Foley 2005). Thus, the use of synthetic inorganic fertilizers has increased dramatically, especially since the late 1960s.

In many developing countries of the world, the use of fertilizers by small landholding farmers is often not economically feasible, due to increasing prices, inaccessibility, and more frequent droughts (Garrity et al. 2010). Additionally, the overapplication of nitrogen and phosphorus fertilizers have been a cause of concern for nonpoint source environmental pollution (Carpenter et al. 1998), human health issues, and increased greenhouse gas emissions such as nitrogen oxides (Nox), carbon dioxide, and methane (Snyder et al. 2009). As a result, progressive approaches have been taken throughout the world to incorporate naturally occurring facilitative plant interactions into farming systems to enhance productivity.

Organic matter is a well-known source of nutrients, however neither animal manure nor green biomass is usually found in adequate quantities to meet the high application rates $\left(10-40 \mathrm{Mg} \mathrm{ha}^{-1} \mathrm{yr}^{-1}\right)$ required to satisfy the nutrient demand of commodity crops (Mafongoya et al. 2006). Arguably, the most renowned approach is 
Evergreen Agriculture. Evergreen farming systems feature both perennial and annual species (trees and food crops) that are maintained and managed on the land throughout the entire year (Garrity et al. 2010). This practice contributes to integrated soil fertility management (ISFM), which maximizes fertilizer and organic resource use efficiency and crop productivity (Sanginga and Woomer 2009). This approach is also associated with reduced tillage, increased residue retention on the soil surface, minimal disturbance, and the incorporation of fertilizer trees.

The term 'fertilizer tree' is commonly used to refer to the utilization of N-fixing trees in agricultural production systems to improve the availability of $\mathrm{N}$ to crops or to rehabilitate degraded lands (Ajayi et al. 2011; Sileshi et al. 2014). Through biological nitrogen fixation, some trees can replenish soil $\mathrm{N}$ reserves by capturing atmospheric nitrogen and making it available in the soil (Nygren et al. 2012). There are additional trees that can recycle the soil's phosphorus $(\mathrm{P})$, calcium $(\mathrm{Ca})$, magnesium $(\mathrm{Mg})$ and potassium $(\mathrm{K})$, but these macronutrients must be sourced externally when they are highly depleted from the soil. The appropriate selection and use of fertilizer trees in agroforestry systems could serve to intensify agricultural production while maximizing conservation benefits (Phalan et al. 2011; Tscharntke et al. 2012).

Integrating Fertilizer Trees into Prevailing Land-use Strategies

The threat of conventional agricultural expansion and the resulting native vegetation and soil loss is now predominant throughout many regions of the world. This, coupled with the ever-worsening effects of climate change, has resulted in a surge of interest in ecological restoration. In Panama, reforestation has been widely promoted and 
implemented over the last two decades (Lamb et al. 2005; Wishnie et al. 2007; Breugel et al. 2011; Hall et al. 2011a, b). However, the land, labor, and financial resources required to establish tree plantations, coupled with a lack of economic returns within the first 5-10 years, are often insurmountable deterrents for landowners (Garen et al. 2009; Paul and Weber 2016). In order for reforestation to be accepted as a viable land use strategy in Latin America, it must be economically viable (Minnemeyer et al. 2011; Calle et al. 2012a). The planting of commercially valuable timber trees as a restoration strategy could be more widely accepted if simultaneously combined with either food and energy crops in "Taungya" agroforestry systems (Schlönvoigt and Beer 2001; Paul and Weber 2016) or with important multipurpose 'fertilizer' trees in silvopastoral systems (Plath et al. 2010).

Silvopastoral systems that combine timber trees and fertilizer shrubs with livestock and forages are considered to be a promising option for the restoration of native tree species in extensive pastures throughout cattle-ranching regions (Plath et al. 2010; Murgueitio et al. 2011; Riedel et al. 2012). Trees provide innumerable ecosystem services, including erosion control, pest control for crops or high value timber trees (Wagner et al. 1996; Hall et al. 2011a), and wildlife habitat. Trees and shrubs can also provide alternative and highly nutritious forage sources during critical periods of the year. In seasonally dry areas of the tropics, ranchers cannot rely on dependable year-long grass productivity. During droughts, grass productivity slows or ceases, and increasing the availability of highly palatable tree fodders is a cost-effective way for ranchers to bridge the dry-season fodder gap (Morrison et al. 1996). Moreover, the integration of fodder shrubs may improve and maintain soil fertility, while possibly providing natural 
nutrient supplies to surrounding crops (Nygren and Leblanc 2009) or pasture grasses (Sierra et al. 2007; Daudin and Sierra 2008; Jalonen et al. 2009b).

Much like natural systems, productivity of an agroforestry system is ultimately the net result of negative and positive interactions among the components (Jose et al. 2004; Jose et al. 2019). In perennial intercropping systems, both aboveground and belowground competitive and facilitative forces act to determine plant survival, productivity, and overall yield in the first few years after plantation establishment (Jose et al. 2006; Kelty 2006). Intercropping might result in substantial silvicultural advantages, including improved microclimate, reduced soil evaporation and improved soil fertility (Vieira et al. 2009). Conversely, competition for light, water and soil nutrients could also serve to reduce or inhibit tree growth. Additionally, exposure to potential allelopathic chemicals or attracted pests could harm tree seedlings (Rao et al. 1998). As important as all of this is, relatively few studies have documented fertilizer tree effects on adjacent site fertility and neighborhood plant productivity in silvopastoral reforestation systems.

\section{Objectives}

The goal of this study was to examine the isolated and combined effects of the fertilizer shrubs Leucaena leucocephala and Tithonia diversifolia on soil physical and chemical properties, water availability, dry matter production of the improved grass Megathyrsus maximus var. Massai (hereafter referred to as Massai), and the growth rate and survival of Albizia saman saplings in the first two years after silvopasture establishment. The objectives of this study were to: 1) establish silvopastures with plantings of Albizia saman surrounded by combinations of L. leucocephala, T. 
diversifolia, and Massai on three farms in the province of Los Santos, Panama, 2)

describe the differences in soil chemical and physical properties among planting regimes (treatments), 3) quantify differences in water availability by assessing soil volumetric water content (VWC) at four depths and plant moisture stress (PMS) of A. saman saplings, 4) evaluate treatment differences in grass dry matter (DM) production, and 5) examine differences in the growth rate and survival of $A$. saman.

We hypothesized that treatments including either of the fodder shrubs together or singly would increase soil fertility indicators such as soil $\mathrm{pH}$, organic matter $(\mathrm{OM})$, cation exchange capacity (CEC), base saturation (BS, \%), macronutrients $\mathrm{Mg}, \mathrm{Ca}$, and $\mathrm{K}$, and plant available $\mathrm{N}$ (nitrate and ammonium) and $\mathrm{P}$ due to $\mathrm{N}$-fixation and $\mathrm{P}$ mobilization induced by the respective shrubs. We expected fertilizer trees to significantly decrease bulk density over the study. We hypothesized that soil VWC would increase proportionally with soil depth, that it would be greatest during the rainy season, and that it would be significantly lower for plots containing shrubs during the dry season only. We expected A. saman PMS to be significantly greater during the dry season as well as for seedlings located within plots containing shrubs due to competition. We hypothesized that plots with fertilizer shrubs would produce significantly more grass dry matter than those without them due to nutrient provisioning. Finally, we expected $A$. saman saplings to benefit from the presence of neighboring fertilizer shrubs, with significantly more saplings surviving and growing faster than those planted without shrubs. 


\section{Materials and Methods}

Study site

An agroforestry field experiment was conducted between July 2015 and August 2017 at three farms on the Pacific side of Panama in the Province of Los Santos $\left(7^{\circ} 15^{\prime} 30^{\prime}, \mathrm{N}, 80^{\circ} 00^{\prime} 15^{\prime \prime} \mathrm{W}\right)$ (Fig. 1). The study area receives an average of $1678 \mathrm{~mm}$ of rain per year, with an extended five-month dry season lasting from December until May (Fig. 2). 2015 - 2016 was a particularly dry year where the El Niño Southern Oscillation (ENSO) event resulted in the third longest dry season on record (173 days) for Panama, with over $90 \%$ of the country experiencing severe drought conditions (Bretfeld et al. 2018).

According to the Soil Atlas of Latin America (Gardi et al. 2015), soils are classified as Dystric Cambisols (Cmdy) in Los Asientos and Calabacito and Vertic Luvisols (LVvr) in Pedasi; they are young and relatively nutrient rich, although degraded from decades of overgrazing (Gardi et al. 2015). The topography is undulating, with slopes ranging between 18 and 40\% grade (Diogenes Ibarra, personal communication). 


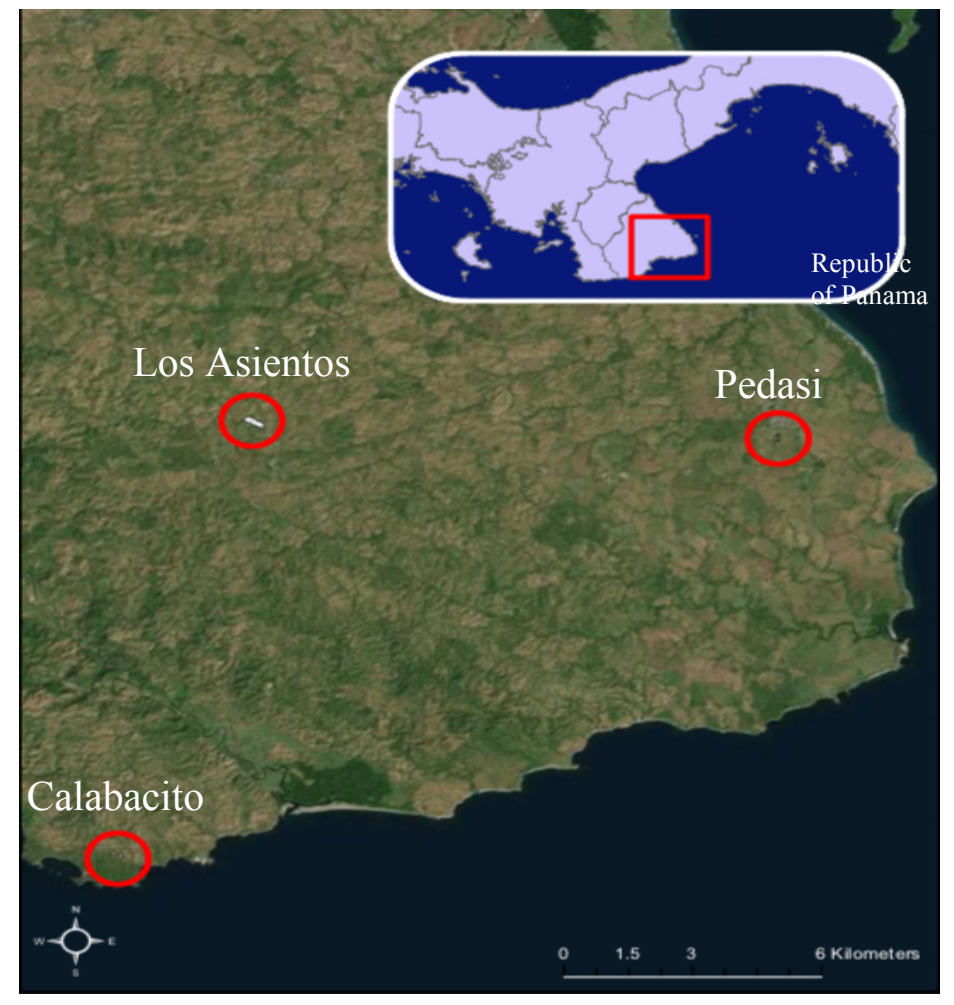

Fig. 1 Locations of the three study sites at the southeastern side of the Azuero Peninsula in the Province of Los Santos, Panama. Each study site was blocked and considered a replicate.

All three sites were grazed extensively historically. Considered part of the dry tropical forest region (Holdridge 1967), the area is a mosaic of pastures dominated by African grasses with scattered Guazuma ulmifolia and Cordia alliodora trees (Griscom et al. 2011), forested riparian zones, and live fences. Common native trees found in remnant forests include Anacardium exelsum, Enterolobium cyclocarpum, Bursera simarouba, Calycophyllum candidissimum, and Hura crepitans, among others. 


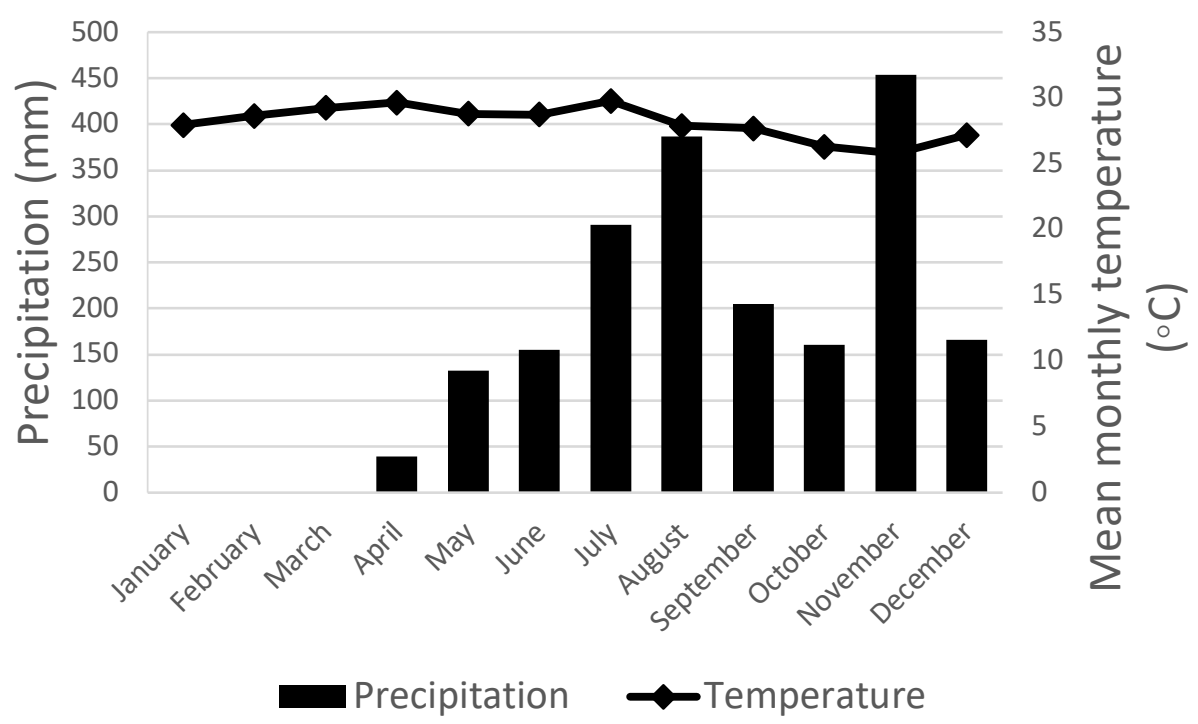

Fig. 2 Precipitation and mean monthly temperature near Playa Venao, Panama in 2016 (A portion of the data was provided by (ETESA 2018).

Confounding factors such as slope, aspect, landform, existing vegetation, and soil type were considered and limited as much as possible in the selection of plots. An effort was made to include ranchers who had expressed an interest in experimenting with silvopasture. Two of the three farms belonged to members of a community Silvopasture Association known as APASPE. Farms were located in Pedasi, Los Asientos, and Calabacito and will be referred to as such throughout.

Species Selections

Overstory Component: Albizia saman

A study looking at the tree planting preferences of landowners in Los Santos concluded that guachapali de ganado (Albizia saman) was one of the most popular trees selected because of its relatively fast growth rate, ability to fix nitrogen, and its 
production of edible pods, fodder, and shade for cattle (Garen et al. 2009). Although highly variable between trees and years, $A$. saman can produce up to 70,000 pods tree ${ }^{-1}$, equating to a total of $272 \mathrm{~kg}$ tree $^{-1}$ year $^{-1}$ (Janzen 1977). Not only are A. saman pods purportedly relished by livestock, but they are produced during the dry season, when herbaceous forages become limited. There have been several reports of increased herbage growth beneath mature $A$. saman crowns, earning the tree the nickname, 'raintree', in that the tree was thought to mysteriously produce rain at night to enable this effect (Durr 2010). For the purposes of this experiment, we planted A. saman seedlings at high densities ( $3 \mathrm{~m} \times 3 \mathrm{~m})$ to encourage growth of straight boles and to minimize crown expansion. Post-experiment, trees will be thinned to a density of around 100 to 150 trees ha ${ }^{-1}$ to promote pasture and shrub production.

\section{Mid-story Component: Leucaena leucocephala and Tithonia diversifolia shrubs}

Two of the most commonly recommended shrubs for tropical intensive silvopastoral systems are Leucaena (Leucaena leucocephala) and Mexican Sunflower (Tithonia diversifolia). These shrubs are periodically coppiced to encourage low, dense growth of the foliage and intermittently browsed by livestock in rotationally grazed paddocks.

L. leucocephala is native to Mexico and naturalized throughout Central and South America. It is extremely palatable to cattle and is tolerant of drought (Vandermeulen et al. 2018a). This species bears root nodules that are formed after infection of the roots with compatible strains of rhizobium bacteria, allowing it to fixate atmospheric nitrogen and possibly increase production in neighboring plants (Kadiata 1997). Shelton and 
Dalzell (2007) claimed that nitrogen fixed by Leucaena returns to the ground and is used by surrounding grasses, increasing the quantity and quality of forage.

T. diversifolia, a shrub belonging to the Asteraceae, is native to Mexico and parts of Central America and is now widely distributed in Africa, Asia, and South America. It is a non-legume shrub that grows to a height of 1-3 m, responds well to coppicing, and quickly produces large quantities of biomass. The leaves of T. diversifolia have been shown to contain unusually high concentrations of nutrients $(\mathrm{N}, \mathrm{P}, \mathrm{K}, \mathrm{Ca}, \mathrm{Mg})$ in comparison with most leguminous species used in agroforestry systems, making it the ideal candidate for the study of interspecific nutrient transfer via leaf decomposition (Jama et al. 2000; Partey et al. 2011). T. diversifolia does not fixate atmospheric $\mathrm{N}$ and does not constitute a net input of nutrients. Thus, if biomass is taken off the site, nutrients must be replenished from an external source.

Although the exact mechanism for why $T$. diversifolia acquires and accumulates nutrients is still largely unknown, some authors have speculated that high tissue nutrient concentrations of phosphorus $(\mathrm{P})$ may be due to an intense association with vesicular arbuscular (VA) mycorrhizal fungi (Jama et al. 2000; Thor Smestad et al. 2002) and/or plant-moderated alterations to the rhizosphere via root exudation of organic anions (George et al. 2002). Because of this, T. diversifolia may have the potential to enhance $\mathrm{P}$ availability to neighboring plants because of its access to pools of $\mathrm{P}$ that are unavailable to other crops (Jama et al. 2000; George et al. 2001; Cobo et al. 2002). Despite the claims that these two species provide the backbone of intensive silvopastoral systems, their combined effects on soil fertility, neighboring plant growth, and water stress have yet to be assessed and are worthy of study. 


\section{Understory Component: African Guineagrass (Megathyrsus maximus var. Massai)}

Guinea grass (Megathyrsus maximus Jacq.) is one of the most important species for cattle production in tropical and subtropical regions (Paciullo et al. 2017) and despite being a $\mathrm{C} 4$ grass, many developed cultivars show medium levels of tolerance to shade (Santiago-Hernández et al. 2016). The genus Megathyrsus has an array of diversity, with most species standing erect, from 0.5 to $3.5 \mathrm{~m}$ high and is recommended for regions with annual rainfall from 800 to $1800 \mathrm{~mm}$ in well-drained soil with medium to high fertility (Muir and Jank 2004). The cultivar Massai was developed for increased productivity with simultaneous drought and shade tolerance characteristics and is currently among the most popular Guinea Grass cultivars in Latin America (Paciullo et al. 2017).

There has been some concern that the aggressive nature of non-native improved pasture grasses may inhibit the growth of associated woody species. However, Andrade and colleagues (2008) suggested that improved grasses may help to stimulate root growth of adjacent trees in a water competitive environment. This root growth could be associated with an intensification of hydraulic redistribution of water and nutrients, contributing to the longevity of forage production in the dry season (Richards and Caldwell 1987)

Planting and Plot Maintenance

On August 13, 2015, we initiated the establishment of simulated three-strata silvopastoral systems at each of the three farms. Albizia saman seedlings $(25 \mathrm{~cm}$ average height) were purchased from a local nursery and planted as the overstory component ${ }^{1} ; L$.

\footnotetext{
${ }^{1}$ Initially, Albizia saman and Tabebuia guayacan seedlings were planted on two separate side by side plots on each farm in a split-plot design. $T$. guayacan seedlings suffered high mortality the first dry season
} 
luecocephala and T. diversifolia were simultaneously planted as the mid-story component; and Massai grasses were broadcast seeded on June 5, 2016 to establish the understory component (Fig. 3). L. luecocephala seedlings (25 cm in height) were also purchased from a local nursery, where they were inoculated with a liquid strain of rhizobium bacteria one week after seed-sowing around the root system of the plant (Forestier et al. 2001). Stem cuttings of $T$. diversifolia were taken from a nearby fodder bank and propagated vegetatively (Fig. 4).

We consider this a simulated silvopasture because all livestock were excluded from plots with fences for the entire two-year study, necessary as per on-farm trials conducted by Hall et al. (2011a). Livestock presence was simulated by periodic defoliation events, described in detail below.

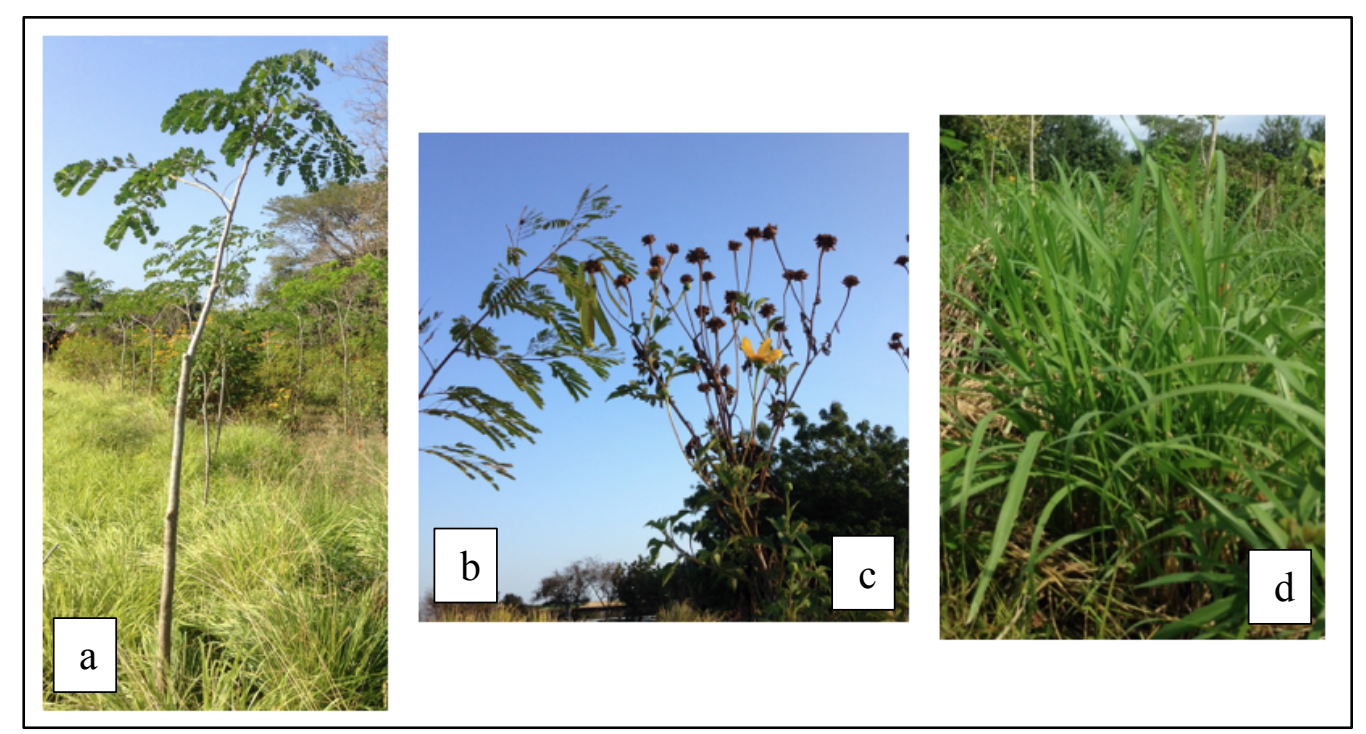

Fig. 3 The four components of the three-strata silvopastoral system established on three farms in the Los Santos, Panama: a) Albizia saman in the overstory, b) Leucaena leucocephala and c) Tithonia diversifolia in the mid-story, and d) Massai grasses in the understory.

and due to cost limitations were not replanted. Subsequently, all T. guayacan plots were abandoned. Please see Appendix B for data collected on T. guayacan seedlings one year after planting. 


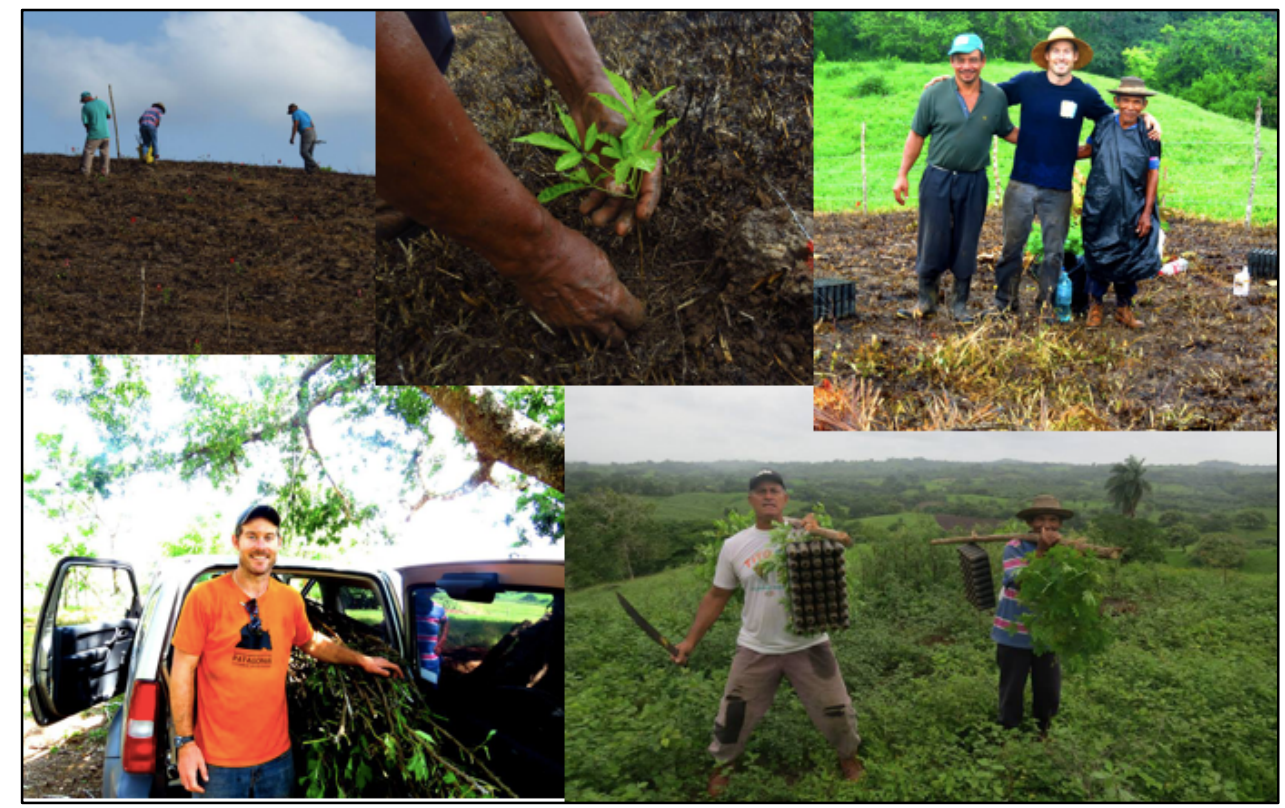

Fig. 4 Planting perennial plants for the establishment of silvopastoral systems in Los Santos, Panama. The photo on the bottom left shows several hundred Tithonia diversifolia stem cuttings ready for planting.

\section{Experimental Design}

A factorial randomized complete block design with three replications (sites) was used. Eight uniform $15 \mathrm{~m}$ x $15 \mathrm{~m}$ plots were established at each site. Twenty-five Albizia saman seedlings were planted on each of the eight plots on a $3 \mathrm{~m} \times 3 \mathrm{~m}$ spacing and surrounded by varying combinations of plants. L. leucocephala, T. diversifolia, and $M$. megathyrsus var. Massai were either present or absent in each plot for a total of eight treatment combinations. The shrubs were planted in a triangular arrangement at a $45^{\circ}$ angle one meter in front of each seedling in a variety of combinations (Fig. 5). In June of 2016, one year after perennial plant establishment, half of the plots ( $a, b, c$, and g) were broadcast seeded with Massai in the following arrangements: 
a) L. leucocephala + L. leucocephala + Massai $\left(2,222\right.$ Leucaena ha $\left.{ }^{-1}\right)\left(\mathrm{L}-\mathrm{M}^{2}\right)$

b) T. diversifolia + T. diversifolia + Massai $\left(2,222\right.$ Tithonia $\left.^{-1}\right)(\mathrm{T}-\mathrm{M})$

c) L. leucocephala + T. diversifolia + Massai $\left(1,111\right.$ Leucaena and Tithonia ha $\left.{ }^{-1}\right)(\mathrm{L}-\mathrm{T}-\mathrm{M})$

d) L. leucocephala + L. leucocephala-Massai (L)

e) T. diversifolia $+T$. diversifolia - Massai $(\mathrm{T})$

f) L. leucocephala + T. diversifolia - Massai (L-T)

g) Massai (M)

h) - L. leucocephala - T. diversifolia - Massai

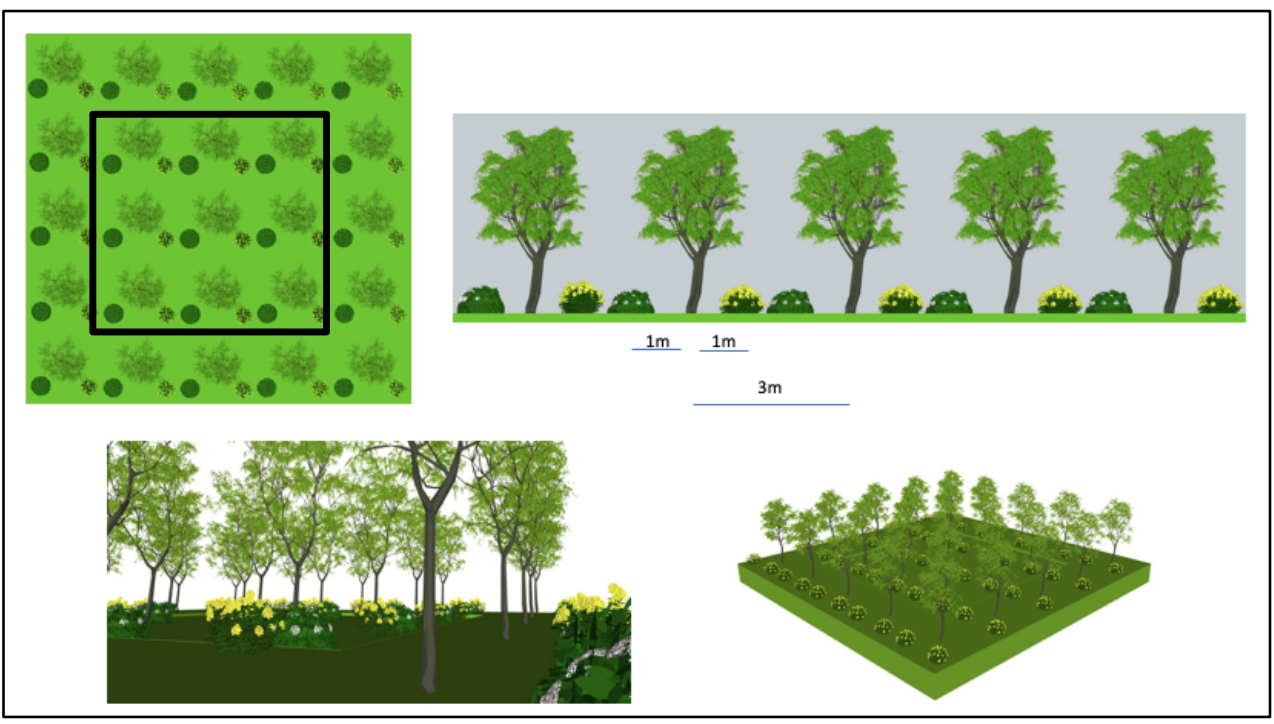

Fig. 5 Several renderings depicting the plantation design. Twenty-five Albizia saman seedlings were planted on a $3 \mathrm{~m}$ x $3 \mathrm{~m}$ spacing. Various combinations of the fertilizer shrubs L. leucocephala and T. diversifolia were planted in a triangular arrangement at a $45^{\circ}$ angle one meter in front of each A. saman. Massai grasses were planted in four of the eight plots. The black box in the middle of the image to the upper left indicates the area wherein trees were sampled.

\footnotetext{
${ }^{2}$ These abbreviations will be used heretofore to denote respective treatments
} 
Measurements were conducted only on the nine innermost plants of each plot, allowing for a $4.5 \mathrm{~m}$ buffer between treatment plots.

Soil Physical and Chemical Properties

Bulk Density and Texture

To measure bulk density, one soil sample was taken in the center of each plot prior to planting in July of 2015 and again two years later after silvopasture establishment. Three depths $(0-5 \mathrm{~cm}, 5-10 \mathrm{~cm}$, and 10-15 cm) were sampled by hammering a metal cylinder with a volume of $500 \mathrm{~cm}^{3}$ into the soil until the square was level with the soil surface. Samples were sent to the soils laboratory at the Smithsonian Tropical Research Institute (STRI) in Panama City, Panama where they were weighed wet, dried at $105^{\circ} \mathrm{C}$ for 24 hours, and weighed again to determine bulk density as soil dry weight $(\mathrm{g})$ volume ${ }^{-1}\left(\mathrm{~cm}^{3}\right)$. Texture was determined with particle size analysis.

\section{Nutrients}

Soil samples were collected prior to planting during the rainy season in July of 2015 and again two years later after plantation establishment. Six randomly distributed soil samples $(200 \mathrm{~g})$ were collected at $0-15 \mathrm{~cm}$ depth with an augur from each plot, airdried without sun or heat, and combined by taking an even amount from each sample. Soil samples (100 g) were sent to the soil testing laboratory at the Smithsonian Tropical Research Institute (STRI) in Panama City, Panamá. Inductively coupled plasma optical emission spectroscopy (ICP-OES) was used with a $\mathrm{BaCl}_{2}$ solution to determine exchangeable $\mathrm{Ca}, \mathrm{Mg}, \mathrm{K}, \mathrm{Mn}, \mathrm{Fe}, \mathrm{Al}$, and $\mathrm{Na}$ and the Mehlich-3 extraction (Mehlich 1984) technique was used to estimate plant available P. Effective Cation exchange 
capacity $\left(\mathrm{ECEC}, \mathrm{cmol}(+) \mathrm{kg}^{-1}\right)$ was calculated by summing the basic and acidic exchangeable cations and Base Saturation (BS, \%) was calculated by dividing the Total Exchangeable Bases (TEB) by the ECEC and multiplying by 100. Another set of samples were sent to the soil testing laboratory at the University of Missouri where they were analyzed for organic matter (OM, \%), total carbon (TC, \%), and total nitrogen (TN, \%), nitrate and ammonium. Total carbon and nitrogen were determined by dry combustion using a $\mathrm{CHN}$ analyzer and organic matter was estimated by loss on ignition. Nitrate and ammonium were extracted in $1 \mathrm{M} \mathrm{KCl}$ solution and determined by colorimetry with an autoanalyzer. Soil $\mathrm{pH}$ was determined using the wet method (1:1 ratio of water to soil) (Schofield and Taylor 1955).

\section{Soil Volumetric Water Content (VWC)}

Soil volumetric water content (VWC) was evaluated once every two months using the Time-Domain-Reflectometry method and a TDR meter (Field Scout ${ }^{\mathrm{TM}}$ TDR Soil Moisture Meter 100). This was measured at four depths $(3.8,7.5,12$, and $20 \mathrm{~cm})$ systematically at twelve locations across each plot for the months of January, March, May, July, September, and November in 2016. Samples were taken $0.5 \mathrm{~m}$ in front of all nine trees within each plot.

Plant Moisture Stress (PMS)

Sapling leaf water potential (Mpa) was measured with a Model 600 pressure chamber (1970s) from the PMS instrument company once during the months of January, March, May, July, September, and November 2016. Samples were taken from leaves of 
lower branches of the nine central timber trees between the hours of 04:00 and 06:00. It is assumed that before dawn, leaves are in equilibrium with the soil water potential (Schultz 1996). Immediately before excision, leaves were placed in a plastic bag and the air was expelled. The leaf was clipped from the stem and transferred to the pressure chamber within the plastic bag which was attached by a paper clip (Turner and Long 1980). Five $\mathrm{mm}$ of the petiole extended externally to the chamber and a rate of nitrogen gas increase of $0.3 \mathrm{Mpa} /$ minute was used. When maximum compensation pressure attainable within the chamber (4 Mpa) was insufficient to cause emergence of xylem sap at the cut surface, a water potential of $>4$ Mpa was recorded.

Grass and Shrub Dry Matter Production Grass

After grasses were fully established, four measurements were taken to represent two sampling seasons: wet (November 5 and December 5, 2016), and dry (February 5 and April 5,2017). At the end of each sampling period, grass within each plot was cut to a uniform height of $20 \mathrm{~cm}$ above the soil and was left to grow for 30 days and 60 days to resemble rotational stocking during the wet and dry seasons, respectively. In each of the four plots containing grasses, grasses were sampled in square grids $(0.5 \mathrm{~m} \times 0.5 \mathrm{~m})$ at eight systematically distributed locations. Grass wet matter was evaluated by cutting the grass to $20 \mathrm{~cm}$ in height with hedge shears, putting clippings into a burlap sack and immediately weighing (Fernandes et al. 2014). Samples were quartered to extract a $400 \mathrm{~g}$ subsample that was sent to the Cooleche Laboratory (Cooperativa de S/M de Productores 
de Leche) in Concepción, Panama. Samples were dried at $60^{\circ} \mathrm{C}$ for 48 hours to weight constancy before determination of dry biomass weight.

\section{L. leucocephala and T. diversifolia Shrubs}

We coppiced all L. leucocephala shrubs at $150 \mathrm{~cm}$ in height once during the dry season (March) and once during the wet season (September) following recommendations for optimal biomass yield given by Duguma et al. (1988). T. diversifolia shrubs were coppiced to $50 \mathrm{~cm}$ in height once in September of 2015 and once in September of 2016, following the recommendations of Partey (2011). Biomass (leaves + small green branches) of five target shrubs was weighed in a burlap sack, quartered to extract a $400 \mathrm{~g}$ subsample, and sent to the Cooleche Laboratory in Concepción, Panama. Samples were dried at $60^{\circ} \mathrm{C}$ for 48 hours to weight constancy before determination of dry biomass weight. All remaining biomass clippings from shrubs were spread throughout their respective plot and where possible, mixed into the soil sub-surface.

Growth and survival of $A$. saman saplings

The nine central timber seedlings per subplot were measured with a metric tape and a Vernier caliper to an accuracy of $1 \mathrm{~cm}$ and $0.1 \mathrm{~mm}$, respectively, two weeks after planting and thereafter twice every six months: twice in the rainy season (August and November 2015), twice in the first dry season (January and April 2016), and twice in the middle of the second rainy season (August and November 2016). Height $(\mathrm{cm})$ and root collar diameter at ground level (from here also rereferred to as "diameter"; $\mathrm{cm}$ ) were 
selected as the main indicators for tree growth. Dead seedlings were replaced with seedlings of approximately the same size before September 2015.

\section{Data Analysis}

We analyzed planting regime effects on response variables including soil chemical properties, seedling height and diameter growth rate, shrub and grass dry matter yield, and PMS, between treatments and sampling dates using a generalized linear mixed model analysis of variance (ANOVA) using the MIXED procedure in SAS (SAS $®$ 2013). We considered the planting regime treatments as main plots and sampling dates as repeated measures (Steel and Torrie 1980). Treatment, sampling date, and their interactions were considered fixed effects while the replicate block, treatment nested under replicate block, and sampling date nested under treatment and replicate block were considered random effects. We examined height and diameter growth increment by calculating an absolute growth rate (AGR; $\mathrm{cm} \mathrm{month}^{-1}$ ) following Kikvidze and Armas (2010) by using the following equation: $\mathrm{AGR}=\left(\mathrm{W}_{2}-\mathrm{W}_{1}\right) /\left(\mathrm{t}_{2}-\mathrm{t}_{1}\right)$, where $\mathrm{W}$ represents either height or root collar diameter at $t_{1}$ at the beginning of the study and $t_{2}$ at the end of the study (in months). All increment parameters were subsequently transformed using the natural logarithm to be used for analysis.

Soil bulk density and VWC were analyzed with a two-way analysis of variance (ANOVA) using a mixed model with a split plot in space and time (Steel and Torrie 1980). The split plot design considered planting regime treatments as main plots, sampling depth as sub-plots, and sampling dates as sub-sub-plots (Steel and Torrie 1980). Sampling dates were analyzed as repeated measures. The advantage of using a mixed 
model approach to analyze these data is the inclusion of a random intercept for each plot that serves to account for the clustered nature of tree plantings (Piepho et al. 2003).

For the parameters sapling height/diameter and shrub fodder dry matter yield (kg $\mathrm{ha}^{-1}$ ), we used a commonly applied statistical methodology known as the "top height tree collective" (Pretzsch 2009). This approach considers only the five most vital seedlings in each plot as targets for analysis; thus, the 15 tallest trees per treatment were selected as the sample population. These trees are most representative of those individuals that could potentially develop a competitive advantage over others. Additionally, the use of only five target trees avoids differences in means that could be caused by high differences in survival between treatments. Treatments with higher survival rates are likely to have wider ranges of heights and diameters than treatments with lower survival rates (Paul and Weber 2016).

To analyze differences in seedling survival, we used a logistic mixed effects analysis of variance (ANOVA) model that provided an odds ratio, or probability of death, for each treatment. To better understand the structure of errors due to treatment, replicate, and tree number, we ran three null models without testing for fixed effects of treatment and month and recorded the -2 Residual Log Pseudo-Likelihood and General Chi-Square / DF fit statistics available using the Glimmix procedure in SAS (SAS® 2013). The second model using the compound symmetry (CS) covariance matrix structure gave the smallest fit statistics, so we used the CS structure for errors.

All dependent variables were tested for normality and $\log _{10}$ transformed when necessary to meet the assumption of homoscedasticity. A simple variance component matrix was used to include the random plot effect and the residual maximum likelihood 
estimation was used to estimate covariance parameters. When significant effects were detected, pair-wise comparisons were performed using the Tukey-adjusted least squares method. Main effects and all interactions were considered statistically significant at $\alpha=$ 0.05 .

\section{Results}

Soil Physical and Chemical Properties

Analysis of physical and chemical soil properties revealed a wide array of soil fertility among sites. Soils in Pedasi were relatively low in fertility, with a mean $\mathrm{pH}$ of 6.34, a mean base saturation (BS) of 91.96\%, a sandy loam texture (Table 1) and a relatively high bulk density ranging between 1.37 and $1.62 \mathrm{~g} \mathrm{~cm}^{-3}$ (Table 2). Soils in Los Asientos were higher in fertility, with a mean $\mathrm{pH}$ of 6.73 , a mean $\mathrm{BS}$ of $98.95 \%$, a loam to clay-loam texture and a lower bulk density ranging between 0.875 and $1.02 \mathrm{~g} \mathrm{~cm}^{-3}$. Soil fertility was highest in Calabacito, with a mean $\mathrm{pH}$ of 6.71 , a mean BS of $99.63 \%$, a loam texture and a bulk density between .704 and $1.02 \mathrm{~g} \mathrm{~cm}^{-3}$.

There were significant treatment $(\mathrm{P}=0.0427)$, depth $(\mathrm{P}=0.0001)$, and year $(\mathrm{P}=$ 0.0227) effects for bulk density. Soil mean bulk density in C was significantly greater than all other treatments, while all other treatments did not statistically differ from one another. Bulk density increased with sampling depth and differed significantly between all three depth profiles. Soil mean bulk density in 2017 was significantly less than that in 2015, decreasing from 0.9238 to $0.9169 \mathrm{~g} \mathrm{~cm}^{-3}$ overall. There were no interaction effects. 
Table 1 Soil texture determined at three sampling depths $(0-5,5-10$, and 10-15 cm) from ten locations within each of the three study sites, Pedasi (P), Los Asientos (L), and Calabacito I.

\begin{tabular}{ccccc}
\hline & \multicolumn{3}{c}{ Soil Texture (\%) } & Texture class \\
\cline { 2 - 4 } Soil depth & Sand & Silt & Clay & \\
\hline Profile 1 (P) & & & & Sandy Loam \\
\hline $0-5$ & 58 & 23.5 & 18.5 & Sandy Loam \\
$5-10$ & 55 & 27.5 & 17.5 & Sandy Loam \\
$10-15$ & 54 & 24 & 22 & Loam \\
\hline Profile 2 (L) & & & & Loam \\
\hline $0-5$ & 45 & 34.5 & 20.5 & Clay Loam \\
$5-10$ & 42.5 & 32.5 & 25 & Loam \\
$10-15$ & 40 & 34 & 26 & Loam \\
\hline Profile 3 I & & & & Loam \\
\hline $0-5$ & 51 & 30.5 & 18.5 & \\
$5-10$ & 50 & 30 & 20 & 22 \\
$10-15$ & 48 & 30 & &
\end{tabular}

Overall, CEC increased significantly from 13.80 to $15.63 \mathrm{cmol} \mathrm{kg}^{-1}$ between pretreatment and post-treatment sampling dates, with the highest value of 16.01 in $\mathrm{T}$ and the lowest value of 13.59 in M. All treatments increased significantly between sampling dates with the exception of treatments $M(P=0.6971)$ and $C(P=0.7648)$. Significant differences did not exist between treatments but there were significant treatment*date interactions, most notably in 2017 between treatments L-T and $\mathrm{M}(\mathrm{P}=0.0312)$ and between treatments $\mathrm{M}$ and $\mathrm{T}(\mathrm{P}=0.0304)$ (Table 3$)$.

There was no overall difference among treatments for base saturation $(\mathrm{P}=$ 0.6024), which ranged from $96.20 \%$ in $\mathrm{M}$ to $97.70 \%$ in L-T. Much like CEC, BS significantly increased from $96.27 \%$ in 2015 to $97.43 \%$ in $2017(\mathrm{P}=0.0058)$. There were no treatment*date interactions. Planting regime did not affect soil $\mathrm{pH}(\mathrm{P}=0.6613)$, nor were there changes in soil $\mathrm{pH}$ over time $(\mathrm{P}=0.4501)$. 
The major cations $\mathrm{Ca}$ and $\mathrm{K}$ both showed marked increases in association with plots that included shrubs. Ca concentrations ranged from $8.39 \mathrm{cmol} \mathrm{kg}^{-1}$ in $\mathrm{M}$ to 11.46 $\mathrm{cmol} \mathrm{kg}^{-1}$ in $\mathrm{T}$. Although not statistically significant $(\mathrm{P}=0.3130)$, the two treatments without shrubs, $\mathrm{C}$ and $\mathrm{M}$, contained the lowest Ca concentrations. Sampling date significantly affected $\mathrm{Ca}$ concentration, with an overall concentration of $9.58 \mathrm{cmol} \mathrm{kg-1}$ in 2015 and 10.390 in $2017(\mathrm{P}=0.0001)$. Similarly, $\mathrm{K}$ concentrations were lowest in $\mathrm{M}$ and $\mathrm{C}$ and higher in all plots with shrubs, but were affected significantly only by sampling date $(\mathrm{P}=0.0001)$, increasing from $.074 \mathrm{cmol} \mathrm{kg}^{-1}$ in 2015 to $0.121 \mathrm{cmol} \mathrm{kg}^{-1}$ in 2017. Mg concentrations followed a different pattern, with the highest concentration of $4.88 \mathrm{cmol} \mathrm{kg}^{-1}$ found in T-M and the lowest concentration of $3.58 \mathrm{cmol} \mathrm{kg}^{-1}$ found in L$\mathrm{T} . \mathrm{Mg}$ was not affected by treatment $(\mathrm{P}=0.2793)$, but concentrations differed in respect to sampling date $(\mathrm{P}=0.0001)$, increasing from $3.80 \mathrm{cmol} \mathrm{kg-1}$ in 2015 to $4.78 \mathrm{cmol} \mathrm{kg}^{-1}$ in 2017. There was a significant interaction between treatment and date $(\mathrm{P}=0.0327)$, with $\mathrm{Mg}$ concentrations in treatment $\mathrm{M}$ decreasing between sampling dates. 
Table 2 Bulk Density recorded pre-trial (2015) and post-trial (2017) at three depths for each of the eight planting regimes at the three study sites in Los Santos, Panama.

\begin{tabular}{|c|c|c|c|c|c|c|c|c|c|c|c|c|}
\hline \multirow[t]{3}{*}{ Treatments } & \multicolumn{12}{|c|}{ Bulk Density $\left(\mathrm{g} \mathrm{cm}^{-3}\right)$} \\
\hline & \multicolumn{4}{|c|}{ Calabacito } & \multicolumn{4}{|c|}{ Los Asientos } & \multicolumn{4}{|c|}{ Pedasi } \\
\hline & $0-5 \mathrm{~cm}$ & $\begin{array}{c}5-10 \\
\mathrm{~cm}\end{array}$ & $\begin{array}{c}10-15 \\
\mathrm{~cm}\end{array}$ & Mean & $0-5$ & $5-10$ & $10-15$ & Mean & $0-5$ & $5-10$ & $10-15$ & Mean \\
\hline \multicolumn{13}{|l|}{$\underline{2015}$} \\
\hline $\mathrm{C}$ & 0.912 & 0.9843 & 0.9922 & 0.9628 & 0.8 & 0.914 & 1.014 & 0.9093 & 1.575 & 1.577 & 1.579 & 1.577 \\
\hline $\mathrm{L}$ & 0.744 & 0.977 & 1.148 & 0.9563 & 0.843 & 0.974 & 1.102 & 0.973 & 1.333 & 1.511 & 1.624 & 1.4893 \\
\hline L-M & 0.839 & 1.032 & 1.077 & 0.9827 & 0.897 & 1.151 & 0.921 & 0.9897 & 1.481 & 1.714 & 1.675 & 1.6233 \\
\hline L-T & 0.733 & 0.827 & 0.959 & 0.8397 & 0.746 & 0.876 & 1.002 & 0.8747 & 1.481 & 1.495 & 1.556 & 1.5107 \\
\hline L-T-M & 0.824 & 0.858 & 1.077 & 0.9197 & 0.704 & 0.849 & 1.082 & 0.8783 & 1.489 & 1.511 & 1.517 & 1.5057 \\
\hline M & 0.854 & 0.917 & 0.942 & 0.9043 & 0.794 & 0.853 & 1.287 & 0.978 & 1.314 & 1.398 & 1.412 & 1.3747 \\
\hline $\mathrm{T}$ & 0.957 & 1.019 & 1.09 & 1.022 & 0.974 & 1.044 & 1.045 & 1.021 & 1.33 & 1.484 & 1.346 & 1.3867 \\
\hline T-M & 0.86 & 0.893 & 0.935 & 0.896 & 0.75 & 1.101 & 1.119 & 0.99 & 1.489 & 1.517 & 1.463 & 1.4897 \\
\hline \multicolumn{13}{|l|}{$\underline{2017}$} \\
\hline $\mathrm{C}$ & 1.054 & 1.098 & 1.138 & 1.0967 & 0.898 & 0.912 & 1.012 & 0.9407 & 1.591 & 1.611 & 1.643 & 1.615 \\
\hline $\mathrm{L}$ & 0.7312 & 0.932 & 1.128 & 0.9304 & 0.812 & 0.913 & 1.102 & 0.9423 & 1.301 & 1.497 & 1.413 & 1.4037 \\
\hline L-M & 0.754 & 0.957 & 1.021 & 0.9107 & 0.785 & 1.012 & 0.991 & 0.9293 & 1.324 & 1.712 & 1.689 & 1.575 \\
\hline L-T & 0.704 & 0.7981 & 0.917 & 0.8064 & 0.7112 & 0.7987 & 0.943 & 0.8176 & 1.298 & 1.431 & 1.499 & 1.4093 \\
\hline L-T-M & 0.798 & 0.811 & 0.987 & 0.8653 & 0.616 & 0.779 & 1.001 & 0.7987 & 1.218 & 1.499 & 1.502 & 1.4063 \\
\hline $\mathrm{M}$ & 0.7988 & 0.884 & 0.913 & 0.8653 & 0.698 & 0.881 & 1.201 & 0.9267 & 1.212 & 1.298 & 1.361 & 1.2903 \\
\hline $\mathrm{T}$ & 0.931 & 1.005 & 1.167 & 1.0343 & 0.897 & 1.002 & 1.023 & 0.974 & 1.214 & 1.398 & 1.412 & 1.3413 \\
\hline T-M & 0.778 & 0.8512 & 0.991 & 0.8734 & 0.712 & 0.913 & 1.102 & 0.909 & 1.213 & 1.491 & 1.513 & 1.4057 \\
\hline
\end{tabular}


Soil organic matter (SOM) increased significantly overall from $2.74 \%$ in 2015 to $3.32 \%$ in $2017(\mathrm{P}=0.0001)$. All treatments showed numerical increases in SOM between sampling dates, with the exception of C, which declined by $0.286 \%$ (Fig. 6). L-T-M revealed the greatest change in SOM between sampling dates, increasing by $1.17 \%$. When compared to all other treatments, L-T-M had significantly greater mean SOM than treatments $\mathrm{M}$ and $\mathrm{C}$, while all treatments contained more SOM than $\mathrm{C}(\mathrm{P}=0.0039)$. There was a significant interaction between treatment and sampling date $(\mathrm{P}=0.0001)$, with all treatments increasing SOM values in time with the exception of treatment $\mathrm{C}$ (Table 4).

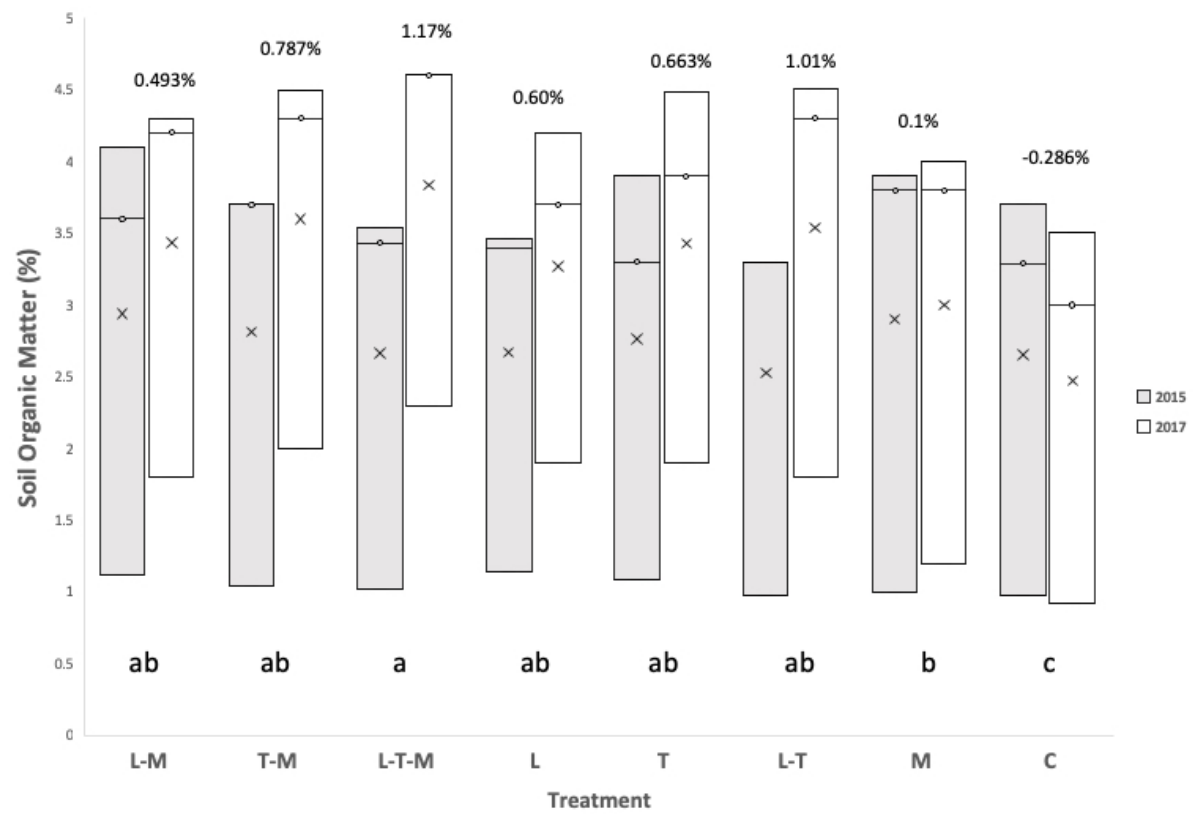

Fig. 6 Changes in mean soil organic matter between 2015 and 2017 for eight planting regime treatments at all three sites combined. Means sharing the same letter are not significantly different from one another at $\mathrm{P}<0.05$. 
Table 3 Pre-trial (2015) and post-trial (2017) measurements of effective cation exchange capacity (ECEC), base saturation (BS), and several important macronutrients for soils collected within the eight planting regime treatments.

\begin{tabular}{|c|c|c|c|c|c|c|c|c|c|c|c|}
\hline \multirow[t]{2}{*}{$\underline{\text { Site }}$} & \multirow[b]{2}{*}{ Treatment } & \multicolumn{2}{|c|}{ ECEC ( $\mathrm{cmol} \mathrm{kg-1)}$} & \multicolumn{2}{|c|}{ BS $(\%)$} & \multicolumn{2}{|c|}{$\mathrm{Ca}$} & \multicolumn{2}{|c|}{$\mathrm{K}$} & \multicolumn{2}{|c|}{$\mathrm{Mg}$} \\
\hline & & 2015 & 2017 & 2015 & 2017 & 2015 & 2017 & 2015 & 2017 & 2015 & 2017 \\
\hline \multirow[t]{9}{*}{ Calabacito } & $\mathrm{C}$ & 27.16 & 27.36 & 99.60 & 99.77 & 19.12 & 18.91 & 0.04 & 0.09 & 7.63 & 8.01 \\
\hline & $\mathrm{L}$ & 22.92 & 24.38 & 99.54 & 99.77 & 17.19 & 17.78 & 0.07 & 0.16 & 5.28 & 6.07 \\
\hline & L-M & 23.49 & 24.62 & 99.43 & 99.77 & 16.47 & 17.38 & 0.09 & 0.12 & 6.51 & 6.69 \\
\hline & L-T & 21.16 & 26.02 & 99.50 & 99.78 & 17.17 & 17.74 & 0.06 & 0.14 & 3.53 & 7.76 \\
\hline & L-T-M & 20.66 & 21.20 & 99.24 & 99.76 & 15.18 & 14.18 & 0.06 & 0.13 & 5.01 & 6.48 \\
\hline & M & 23.97 & 23.52 & 99.55 & 99.73 & 15.29 & 15.03 & 0.10 & 0.11 & 8.22 & 8.04 \\
\hline & $\mathrm{T}$ & 25.27 & 26.38 & 99.60 & 99.81 & 18.87 & 19.21 & 0.08 & 0.13 & 5.96 & 6.69 \\
\hline & $\mathrm{T}-\mathrm{M}$ & 20.13 & 23.42 & 99.37 & 99.83 & 13.35 & 15.02 & 0.08 & 0.13 & 6.31 & 7.86 \\
\hline & Mean & 23.09 & 24.61 & 99.48 & 99.78 & 16.58 & 16.91 & 0.07 & 0.13 & 6.06 & 7.20 \\
\hline \multirow[t]{9}{*}{ Los Asientos } & $\mathrm{C}$ & 14.49 & 15.02 & 98.71 & 99.36 & 8.40 & 8.46 & 0.13 & 0.15 & 5.55 & 6.01 \\
\hline & $\mathrm{L}$ & 17.72 & 18.60 & 98.88 & 99.34 & 12.11 & 12.01 & 0.13 & 0.16 & 5.12 & 6.11 \\
\hline & L-M & 16.26 & 18.95 & 98.11 & 99.06 & 9.38 & 11.27 & 0.10 & 0.20 & 6.28 & 7.02 \\
\hline & L-T & 14.62 & 19.78 & 98.87 & 99.60 & 11.49 & 13.38 & 0.15 & 0.21 & 2.70 & 5.93 \\
\hline & L-T-M & 14.15 & 19.56 & 98.07 & 99.12 & 10.93 & 12.97 & 0.08 & 0.17 & 2.74 & 6.02 \\
\hline & M & 14.35 & 14.35 & 98.65 & 99.31 & 8.12 & 8.22 & 0.12 & 0.13 & 5.68 & 5.59 \\
\hline & $\mathrm{T}$ & 17.45 & 20.49 & 98.78 & 99.47 & 12.21 & 13.92 & 0.08 & 0.18 & 4.73 & 6.02 \\
\hline & T-M & 17.50 & 20.78 & 98.62 & 99.32 & 10.79 & 12.22 & 0.11 & 0.19 & 6.20 & 8.03 \\
\hline & Mean & 15.82 & 18.45 & 98.58 & 99.32 & 10.43 & 11.56 & 0.11 & 0.19 & 4.87 & 6.34 \\
\hline \multirow[t]{9}{*}{ Pedasi } & $\mathrm{C}$ & 2.07 & 1.97 & 90.72 & 90.32 & 1.43 & 1.33 & 0.06 & 0.05 & 0.34 & 0.33 \\
\hline & $\mathrm{L}$ & 2.56 & 4.39 & 88.40 & 92.05 & 1.53 & 2.89 & 0.04 & 0.09 & 0.63 & 1.07 \\
\hline & L-M & 2.73 & 3.86 & 91.94 & 94.42 & 1.93 & 2.64 & 0.01 & 0.03 & 0.54 & 0.97 \\
\hline & L-T & 2.74 & 5.06 & 92.38 & 96.08 & 1.94 & 3.66 & 0.05 & 0.11 & 0.48 & 1.06 \\
\hline & L-T-M & 2.92 & 4.85 & 92.85 & 95.87 & 2.13 & 3.48 & 0.03 & 0.07 & 0.51 & 1.12 \\
\hline & $\mathrm{M}$ & 2.87 & 2.49 & 91.15 & 88.80 & 1.99 & 1.68 & 0.05 & 0.04 & 0.52 & 0.47 \\
\hline & $\mathrm{T}$ & 2.33 & 4.14 & 89.66 & 93.46 & 1.58 & 2.98 & 0.04 & 0.09 & 0.42 & 0.79 \\
\hline & T-M & 1.78 & 3.86 & 88.79 & 94.54 & 1.25 & 3.01 & 0.01 & 0.03 & 0.28 & 0.63 \\
\hline & Mean & 2.50 & 3.83 & 90.74 & 93.19 & 1.72 & 2.71 & 0.04 & 0.06 & 0.47 & 0.80 \\
\hline
\end{tabular}


Total $\mathrm{C}$ ranged from $14132 \mathrm{mg} \mathrm{kg}^{-1}$ in $\mathrm{C}$ to $15483 \mathrm{mg} \mathrm{kg}^{-1}$ in L-T-M and was strongly positively correlated with $\mathrm{SOM}(\mathrm{r}=0.95288, \mathrm{P}=0.0001)$ (Fig. 7). Total $\mathrm{C}$ was significantly affected by planting regime $(\mathrm{P}=.0115)$, with all six treatments including shrubs producing significantly more total $\mathrm{C}$ than those without ( $\mathrm{M}$ and $\mathrm{C})$. Over the course of the study, overall total C increased significantly by $9.56 \%$ from $14795 \mathrm{mg} \mathrm{kg}^{-1}$ in 2015 to $15194 \mathrm{mg} \mathrm{kg}^{-1}$ in $2017(\mathrm{P}=0.0002)$. There was a borderline treatment * date effect, with treatments T, M, L, and C showing no significant change over the two years, while treatments T-M, L-T-M, L-T, and L-M did.

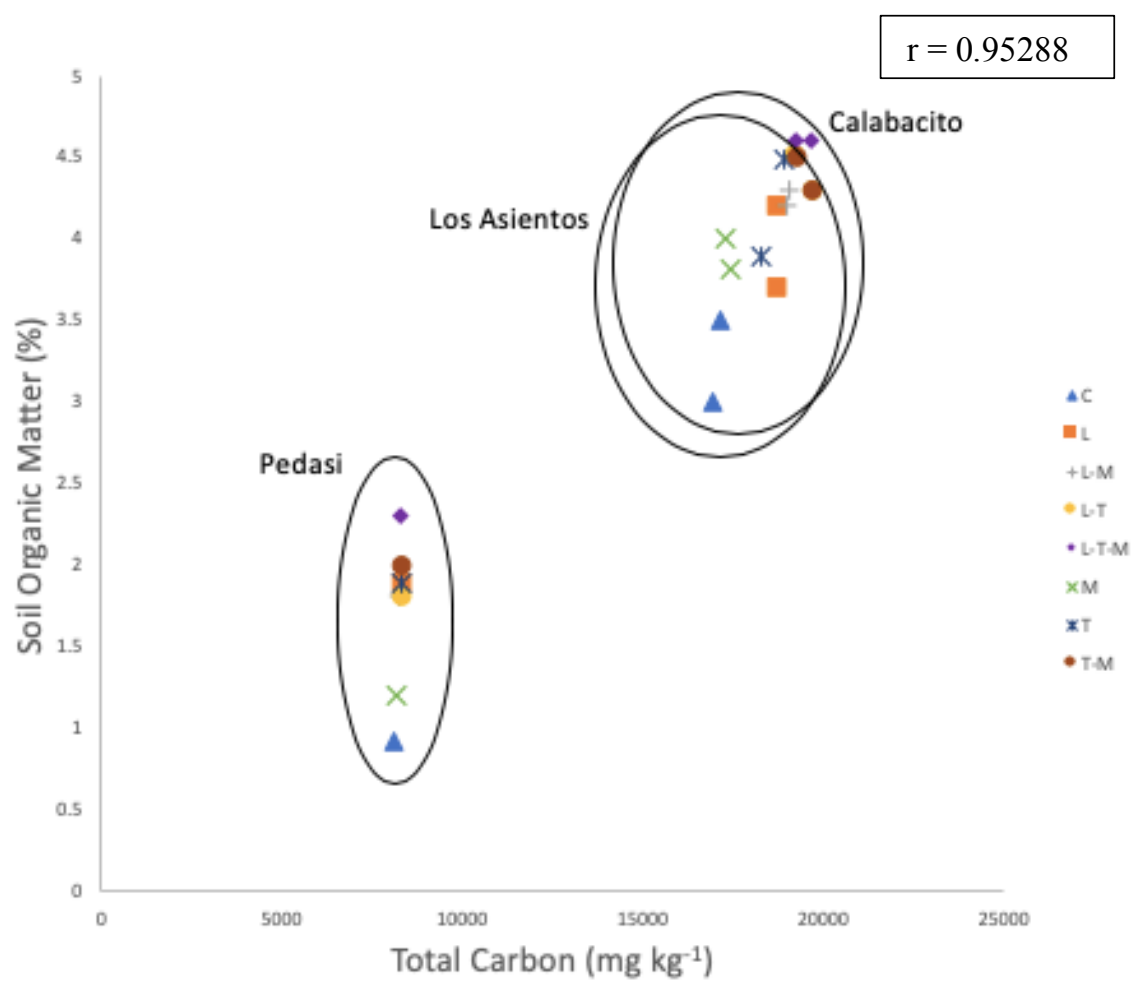

Fig. 7 Relationship between mean soil organic matter (SOM) and mean total carbon (TC) sampled in 2017 for three sites and eight treatments. 
Table 4 Pre-trial (2015) and post-trial (2017) soil organic matter (OM), total carbon (TC), total nitrogen (TN), carbon to nitrogen ratio $(\mathrm{C}: \mathrm{N})$, nitrate, ammonium, and Mehlich-3 $\mathrm{P}$ for all eight planting regime treatments at three sites in Los Santos, Panama.

\begin{tabular}{|c|c|c|c|c|c|c|c|c|c|c|c|c|c|c|c|}
\hline \multirow[t]{2}{*}{$\underline{\text { Site }}$} & \multirow[b]{2}{*}{ Treatment } & \multicolumn{2}{|c|}{$\mathrm{OM}$} & \multicolumn{2}{|c|}{$\mathrm{TC}$} & \multicolumn{2}{|c|}{$\mathrm{TN}$} & \multicolumn{2}{|c|}{$\mathrm{C}: \mathrm{N}$} & \multicolumn{2}{|c|}{ Nitrate } & \multicolumn{2}{|c|}{ Ammonium } & \multicolumn{2}{|c|}{ Mehlich-3 P } \\
\hline & & 2015 & 2017 & 2015 & 2017 & 2015 & 2017 & 2015 & 2017 & 2015 & 2017 & 2015 & 2017 & 2015 & 2017 \\
\hline \multirow{9}{*}{$\underline{C}$} & $\mathrm{C}$ & 3.60 & 3.50 & 17544 & 17110 & 1569 & 1594 & 11.19 & 10.76 & 2.24 & 2.50 & 9.22 & 9.22 & 1.41 & 1.31 \\
\hline & $\mathrm{L}$ & 4.20 & 4.20 & 18143 & 18700 & 1599 & 1713 & 11.35 & 8.60 & 2.01 & 2.68 & 9.51 & 9.92 & 1.90 & 1.79 \\
\hline & L-M & 3.60 & 4.20 & 18054 & 18940 & 1647 & 1771 & 10.96 & 10.70 & 2.48 & 2.78 & 8.27 & 10.27 & 1.49 & 1.40 \\
\hline & L-T & 3.30 & 4.30 & 18741 & 19697 & 1644 & 1806 & 11.40 & 10.96 & 1.99 & 2.83 & 9.88 & 10.44 & 1.75 & 1.95 \\
\hline & L-T-M & 3.43 & 4.60 & 18847 & 19920 & 1656 & 1811 & 11.38 & 11.01 & 2.45 & 2.84 & 9.13 & 10.50 & 2.30 & 2.50 \\
\hline & M & 3.80 & 4.00 & 17400 & 17320 & 1562 & 1514 & 11.14 & 11.47 & 2.15 & 2.37 & 8.12 & 8.76 & 1.68 & 1.48 \\
\hline & $\mathrm{T}$ & 3.30 & 3.90 & 18131 & 18240 & 1718 & 1796 & 10.55 & 10.47 & 2.11 & 2.81 & 8.78 & 10.38 & 2.02 & 2.32 \\
\hline & T-M & 3.70 & 4.30 & 18960 & 19680 & 1603 & 1695 & 11.83 & 11.64 & 2.12 & 2.65 & 8.43 & 9.80 & 1.55 & 1.75 \\
\hline & Mean & 3.62 & 4.13 & 18228 & 18701 & 1625 & 1713 & 11.23 & 10.70 & 2.19 & 2.68 & 8.92 & 9.91 & 1.76 & 1.81 \\
\hline \multirow[t]{9}{*}{$\underline{\mathrm{L}}$} & $\mathrm{C}$ & 3.10 & 3.40 & 17008 & 16980 & 1506 & 1538 & 11.30 & 11.10 & 2.31 & 2.40 & 8.55 & 8.87 & 1.40 & 1.80 \\
\hline & $\mathrm{L}$ & 3.40 & 3.70 & 18522 & 18710 & 1588 & 1685 & 11.67 & 11.38 & 2.08 & 2.64 & 8.89 & 9.74 & 2.63 & 2.43 \\
\hline & L-M & 4.10 & 4.30 & 18248 & 19020 & 1505 & 1613 & 12.12 & 11.81 & 2.04 & 2.53 & 8.99 & 9.34 & 1.43 & 1.73 \\
\hline & L-T & 3.30 & 4.20 & 17993 & 19200 & 1593 & 1668 & 11.29 & 11.39 & 2.29 & 2.61 & 9.12 & 9.63 & 2.44 & 3.10 \\
\hline & L-T-M & 3.54 & 4.60 & 18092 & 19420 & 1600 & 1799 & 11.30 & 11.03 & 2.41 & 2.76 & 9.01 & 10.21 & 1.70 & 2.07 \\
\hline & M & 3.90 & 3.80 & 17621 & 17430 & 1490 & 1491 & 11.82 & 11.70 & 2.27 & 2.34 & 8.88 & 8.64 & 2.05 & 1.99 \\
\hline & $\mathrm{T}$ & 2.90 & 3.90 & 18021 & 18920 & 1600 & 1714 & 11.26 & 10.71 & 2.32 & 2.68 & 8.01 & 9.92 & 2.66 & 2.66 \\
\hline & T-M & 3.70 & 4.50 & 18476 & 19230 & 1606 & 1726 & 11.50 & 11.18 & 2.43 & 2.70 & 8.13 & 9.98 & 1.51 & 1.91 \\
\hline & Mean & 3.49 & 4.05 & 17998 & 18614 & 1561 & 1654 & 11.53 & 11.29 & 2.27 & 2.58 & 8.70 & 9.54 & 1.98 & 2.21 \\
\hline \multirow[t]{9}{*}{$\underline{\mathrm{P}}$} & $\mathrm{C}$ & 0.97 & 1.10 & 8040 & 8109 & 682 & 714 & 11.80 & 11.86 & 1.02 & 1.11 & 4.25 & 4.12 & 2.87 & 2.87 \\
\hline & $\mathrm{L}$ & 1.14 & 1.90 & 8241 & 8310 & 878 & 940 & 9.38 & 8.84 & 1.05 & 1.48 & 4.92 & 5.45 & 4.18 & 4.08 \\
\hline & L-M & 1.12 & 1.80 & 8054 & 8210 & 816 & 855 & 9.87 & 9.66 & 1.08 & 1.33 & 3.54 & 4.93 & 3.20 & 3.50 \\
\hline & L-T & 0.98 & 1.80 & 8096 & 8308 & 748 & 845 & 10.82 & 9.65 & 0.97 & 1.32 & 4.72 & 4.87 & 3.27 & 4.14 \\
\hline & L-T-M & 1.02 & 2.30 & 8208 & 8410 & 814 & 912 & 10.09 & 9.24 & 1.11 & 1.43 & 4.41 & 5.28 & 3.02 & 3.52 \\
\hline & $\mathrm{M}$ & 1.00 & 1.20 & 8182 & 8140 & 664 & 668 & 12.33 & 12.33 & 0.95 & 1.04 & 3.89 & 3.83 & 3.84 & 3.54 \\
\hline & $\mathrm{T}$ & 1.19 & 1.90 & 8208 & 8320 & 854 & 897 & 9.61 & 9.35 & 1.09 & 1.40 & 4.90 & 5.16 & 4.91 & 5.17 \\
\hline & T-M & 1.04 & 2.00 & 8257 & 8330 & 708 & 794 & 11.66 & 10.54 & 0.98 & 1.24 & 3.76 & 4.58 & 3.03 & 3.23 \\
\hline & Mean & 1.06 & 1.75 & 8161 & 8267 & 770 & 828 & 10.69 & 10.19 & 1.03 & 1.29 & 4.30 & 4.78 & 3.54 & 3.76 \\
\hline
\end{tabular}


Total $\mathrm{N}$ was also affected significantly by treatment $(\mathrm{P}=0.0001)$ and date $(\mathrm{P}=$ 0.0001). Total $\mathrm{N}$ ranged from $1267.02 \mathrm{mg} \mathrm{kg}^{-1}$ in $\mathrm{C}$ to $1430 \mathrm{mg} \mathrm{kg}^{-1}$ in $\mathrm{T}$. Much like for $\mathrm{TC}$, all treatments including shrubs had significantly greater total $\mathrm{N}$ than those without shrubs ( $\mathrm{M}$ and $\mathrm{C}$ ), however, T-M had significantly lower TN than the other treatments with shrubs. TN increased significantly by $5.9 \%$ from $1318.72 \mathrm{mg} \mathrm{kg}^{-1}$ in 2015 to 1397.17 $\mathrm{m} \mathrm{kg} \mathrm{k}^{-1}$ in 2017. There was a significant interaction between treatment and date $(\mathrm{P}=0.0009)$, with $\mathrm{TN}$ increasing in all treatments except for $\mathrm{M}$, where it decreased.

Plant available $\mathrm{N}$ made up $0.687 \%$ of total $\mathrm{N}$ and was highest in the form of ammonium. Ammonium ranged between $7.021 \mathrm{mg} \mathrm{kg}^{-1}$ in treatment $\mathrm{M}$ and $8.11 \mathrm{mg} \mathrm{kg}^{-1}$ in treatment L-T. Both planting regime $(\mathrm{P}=0.0007)$ and date $(\mathrm{P}=0.0001)$ had significant effects on soil ammonium concentrations (Table 5). Treatments L-T, L-T-M, and $\mathrm{L}$ had significantly higher mean ammonium concentrations than the remaining treatments. Overall ammonium concentrations increased by $10.56 \%$ from $7.3052 \mathrm{mg} \mathrm{kg-1}$ in 2015 to $8.0765 \mathrm{mg} \mathrm{kg}^{-1}$ in 2017 . Nitrate levels differed significantly between treatments $(\mathrm{P}=0.0295)$ and date $(\mathrm{P}=0.0001)$. L-T-M had the highest nitrate concentration of $2.167 \mathrm{mg} \mathrm{kg}-1$, which was significantly greater than treatments L-T, L, C, and M. M had the lowest nitrate concentration at 1.8527. Overall nitrate concentration increased from $1.83 \mathrm{mg} \mathrm{kg}-1$ in 2015 to $2.185 \mathrm{mg} \mathrm{kg}-1$ in 2017 (Table 5).

The overall C:N ratio significantly decreased over the course of the study, from 11.151 in 2015 to 10.724 in $2017(\mathrm{P}=0.1223)$ (Table 4). However, there were no treatment $(\mathrm{P}=0.1223)$ or treatment*date effects $(\mathrm{P}=0.3572)$.

Significant differences existed for Mehlich-3 P between treatments $(\mathrm{P}=0.0219)$, dates $(\mathrm{P}=0.0008)$, and for the treatment*date interaction $(\mathrm{P}=0.0044)$. Post-hoc tests 
revealed significantly greater $\mathrm{P}$ concentrations in treatment $\mathrm{T}$ than for all other treatments with the exception of L-T $(\mathrm{P}=0.1455)$ and $\mathrm{L}(\mathrm{P}=0.1947)$ (Fig. 9). However, treatments differed significantly in 2015 at the start of the experiment, making absolute value comparisons impossible. Assessing the differences in relative changes between years among treatments is a more appropriate analysis in this case. Two treatments, L and M, showed non-significant decreases in plant available P between 2015 and 2017.

Conversely, the treatments T-M $(\mathrm{P}=0.0325), \mathrm{L}-\mathrm{T}-\mathrm{M}(\mathrm{P}=0.0064)$, and L-T $(\mathrm{P}=0.0001)$, showed significant increases in plant available P over the study (Fig. 8).

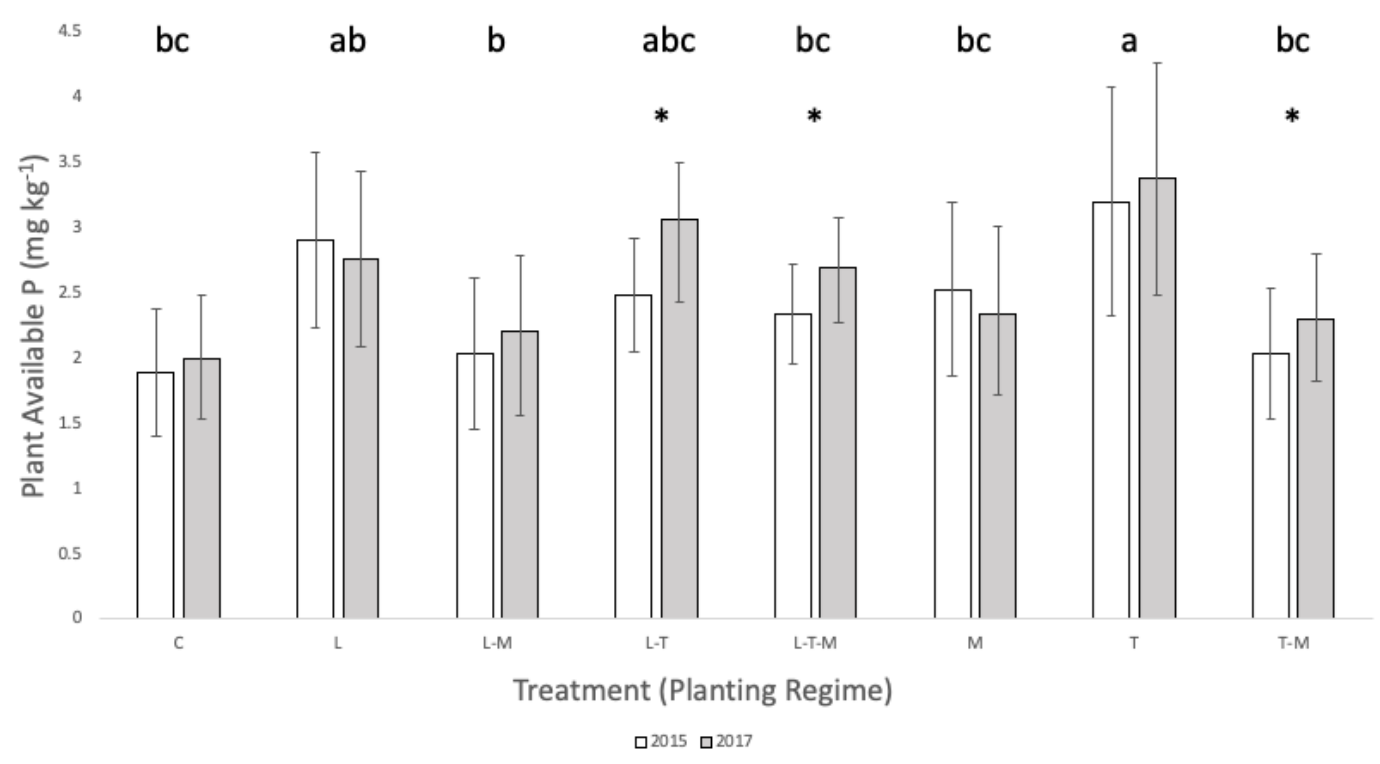

Fig. 8 Least squares means (LSMs) with standard errors for plant available P estimated with the Mehlich-3 P extraction. Means sharing the same letter are not significantly different from one another at $\mathrm{P}<0.05$. Significant differences in LSMs between years are indicated with an *. 
Table 5 Pre-trial (2015) and post-trial (2017) measurements taken for plant available ammonium $\left(\mathrm{NH}_{4}^{+}\right)$and nitrate $\left(\mathrm{NO}_{3}{ }^{-}\right)$. Overall, ammonium and nitrate increased over time, with lowest concentrations in $\mathrm{M}$ and highest concentrations in L-T-M for both variables.

\begin{tabular}{|c|c|c|c|c|c|c|c|c|c|}
\hline Site & $\begin{array}{c}\text { Variable } \\
\text { (year) }\end{array}$ & $\mathbf{C}$ & $\mathbf{L}$ & L-M & L-T & L-T-M & $\mathbf{M}$ & $\mathbf{T}$ & $\mathbf{T}-\mathbf{M}$ \\
\hline Calabacito & & 9.22 & 9.51 & 8.27 & 9.88 & 9.13 & 8.12 & 8.78 & 8.43 \\
\hline Los Asientos & $\mathrm{NH}_{4}^{+}(2015)$ & 8.55 & 8.89 & 8.99 & 9.12 & 9.01 & 8.88 & 8.01 & 8.13 \\
\hline Pedasi & & 4.25 & 4.92 & 3.54 & 4.72 & 4.41 & 3.89 & 4.90 & 3.76 \\
\hline Calabacito & & 9.22 & 9.92 & 10.27 & 10.44 & 10.50 & 8.76 & 10.38 & 9.80 \\
\hline Los Asientos & $\mathrm{NH}_{4}{ }^{+}(2017)$ & 8.87 & 9.74 & 9.34 & 9.63 & 10.21 & 8.64 & 9.92 & 9.98 \\
\hline Pedasi & & 4.12 & 5.45 & 4.93 & 4.87 & 5.28 & 3.83 & 5.16 & 4.58 \\
\hline Calabacito & & 2.24 & 2.01 & 2.48 & 1.99 & 2.45 & 2.15 & 2.11 & 2.12 \\
\hline Los Asientos & $\mathrm{NO}_{3}^{-}(2015)$ & 2.31 & 2.08 & 2.04 & 2.29 & 2.41 & 2.27 & 2.32 & 2.43 \\
\hline Pedasi & & 1.02 & 1.05 & 1.08 & 0.97 & 1.11 & 0.95 & 1.09 & 0.98 \\
\hline Calabacito & & 2.50 & 2.68 & 2.78 & 2.83 & 2.84 & 2.37 & 2.81 & 2.65 \\
\hline Los Asientos & $\mathrm{NO}_{3}^{-}(2017)$ & 2.40 & 2.64 & 2.53 & 2.61 & 2.76 & 2.34 & 2.68 & 2.70 \\
\hline Pedasi & & 1.11 & 1.48 & 1.33 & 1.32 & 1.43 & 1.04 & 1.40 & 1.24 \\
\hline
\end{tabular}




\section{Soil Volumetric Water Content (VWC)}

There were no significant treatment effects for soil VWC $(\mathrm{P}=0.8417)$. Variability was high for all treatments and all sampling dates, making it impossible to discern treatment differences (Fig. 9). There were strong month $(\mathrm{P}=0.0001)$ and sampling depth differences $(\mathrm{P}=0.0001)$. Post-hoc tests showed that mean VWC differed significantly between all months, with the exception of July and September $(\mathrm{P}=0.1463)$ and July and November $(\mathrm{P}=0.0823)$. As expected, months falling within the dry season (January, March, and May) had significantly lower mean VWC (26.11, 9.58, and 30.39\%, respectively) than those falling within the wet season (July: 46.24\%; September: 49.65\%; and November: $42.51 \%$ ). VWC increased consistently with sampling depth, with a least squares mean of $26.25 \%$ at $3.8 \mathrm{~cm}, 33.20 \%$ at $7.5 \mathrm{~cm}, 35.79 \%$ at $12 \mathrm{~cm}$, and $41.09 \%$ at

$20 \mathrm{~cm}$. There were also treatment*depth $(\mathrm{P}=0.0001$ and month*depth $(\mathrm{P}=0.0001)$ interactions. The pattern of increasing VWC with depth was not observed in M and L-M during July and M and T-M during November, two of the three rainiest months of the year. Rather, highest VWC was measured at $12 \mathrm{~cm}$ and $7.5 \mathrm{~cm}$, for July and November, respectively.

\section{Plant Moisture Stress}

There were no treatment effects on sapling mean leaf water potential $(\mathrm{P}=$ 0.6285). Mean leaf water potential varied across sites, with saplings in Pedasi exhibiting the lowest value at $-3.48 \mathrm{Mpa}$ in treatment $\mathrm{C}$ during the month of March (Fig. 10). Treatment least squares means ranged between $-1.75 \mathrm{Mpa}$ in $\mathrm{M}$ to -2.03 in T-M. Significant differences existed between all months $(\mathrm{P}=0.0001)$ with the exception of 
January and May, two months coinciding with the beginning of the dry season and the beginning of the rainy season $(\mathrm{P}=0.2955)$. There were no interaction effects.
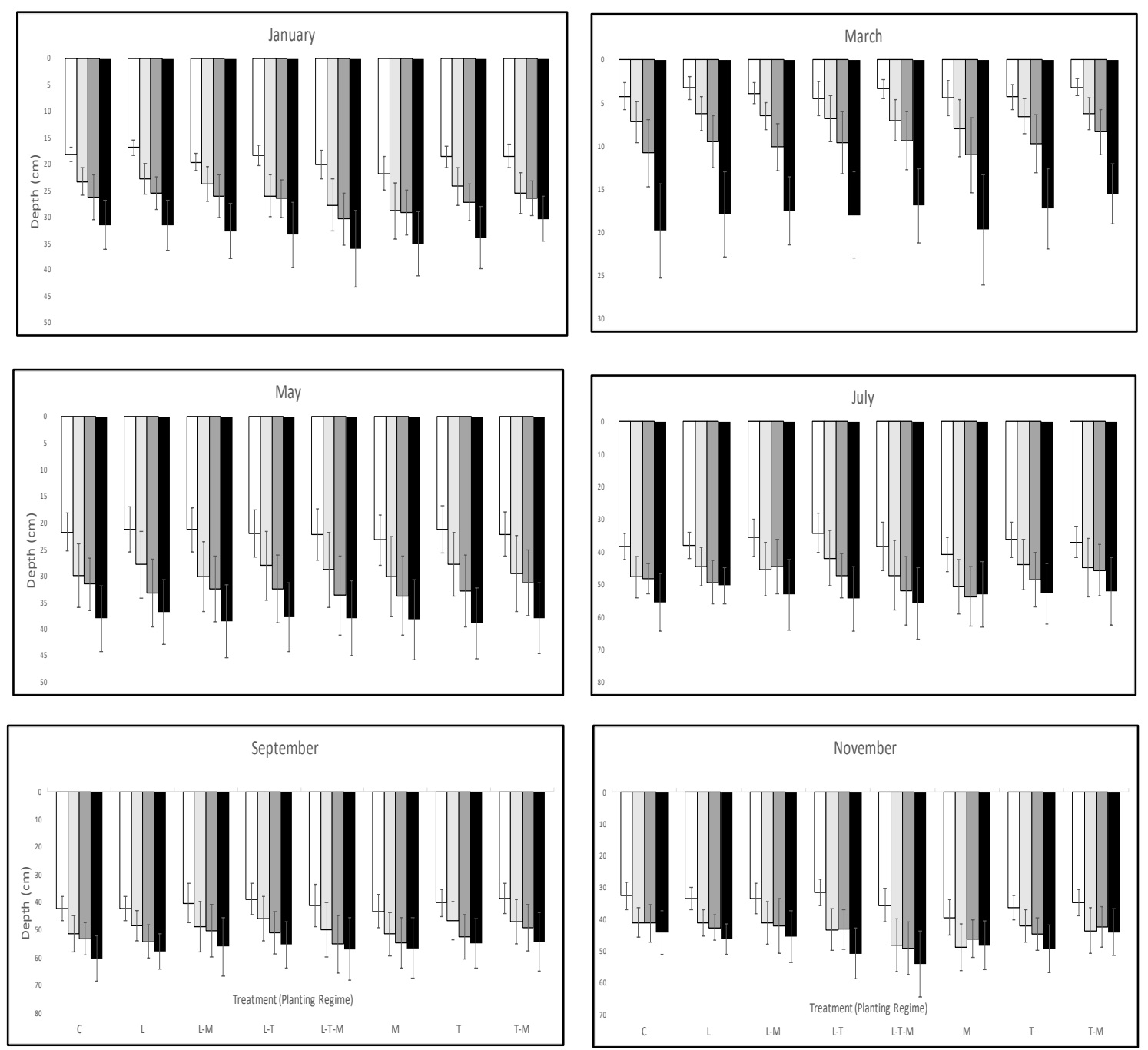

Soil Depth (cm)

\section{$\square 3.8 \square 7.5 \square 12 \square 20$}

Fig. 9 Soil volumetric water content (VWC) at four sampling depths $(3.8,7.5,12$, and $20 \mathrm{~cm}$ ) for the eight planting regimes sampled over 6 months throughout 2016. Least squares means with standard error are presented. 

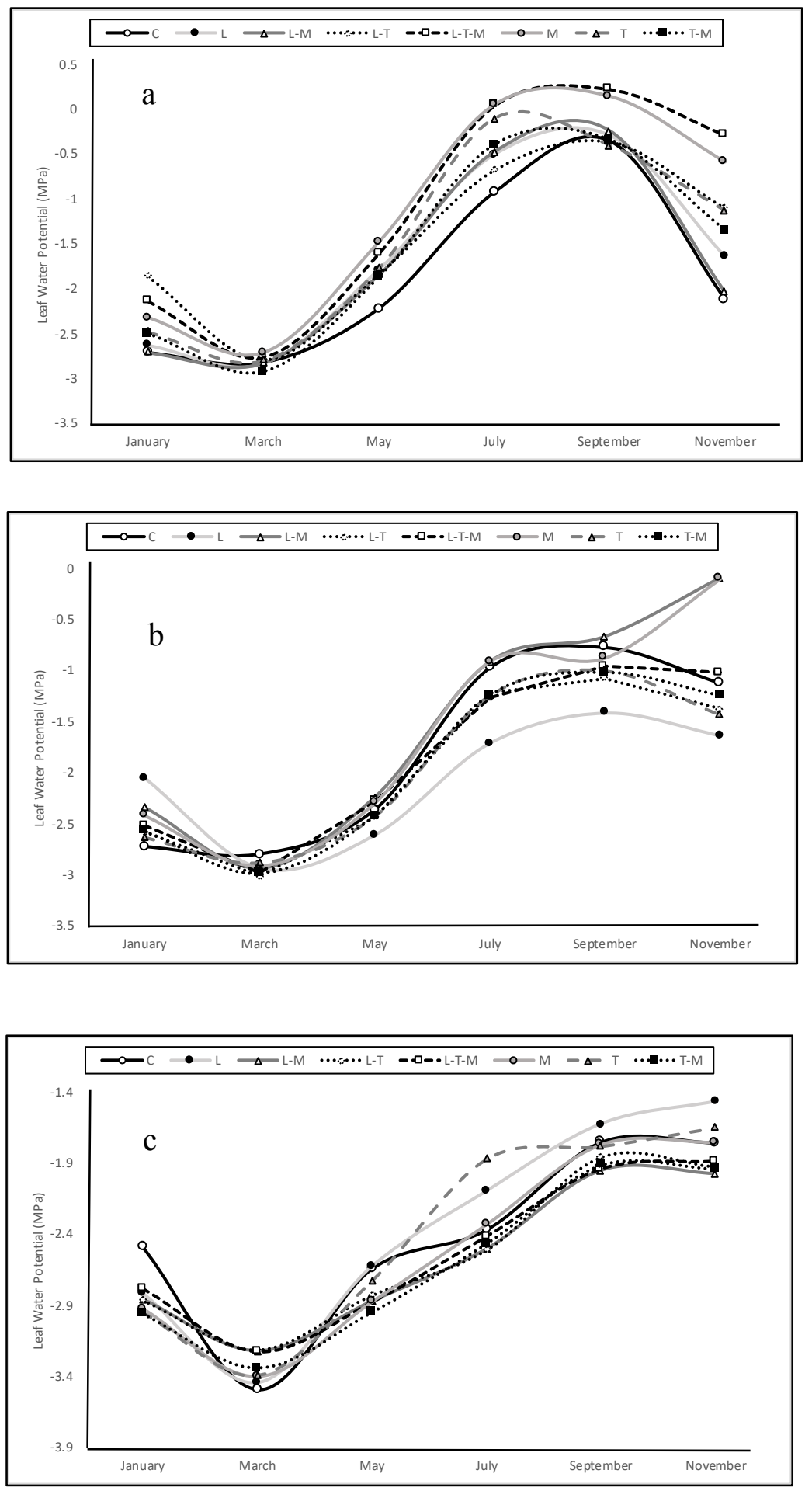

Fig. 10 Mean leaf water potential (Mpa) for $A$. saman saplings growing in association with eight different planting regimes in 2016 at the three sites a) Calabacito, b) Los Asientos, and c) Pedasi. 


\section{Massai Grass Dry Matter Production}

Cumulatively, $\log _{10}$ mean grass dry matter $(\mathrm{DM})$ production was greatest in L-M for all sites (Fig. 11) but was only marginally significantly different from the other treatments $(\mathrm{P}=0.0552)$. Mean annual $\mathrm{DM}$ production $\mathrm{ha}^{-1}$ totaled $11,761.87 \pm 168.42$, $7,098.73 \pm 287.57,8,258.13 \pm 547.12$, and 8,980.4 \pm 101.33 for L-M, M, L-T-M, and T$\mathrm{M}$, respectively. As expected, there were significant differences between sampling periods $(\mathrm{P}=0.0001)$, with greater quantities of dry matter produced in the months of September and November than in the months of February and April. There were no treatment*month interaction effects $(\mathrm{P}=0.9137)$.

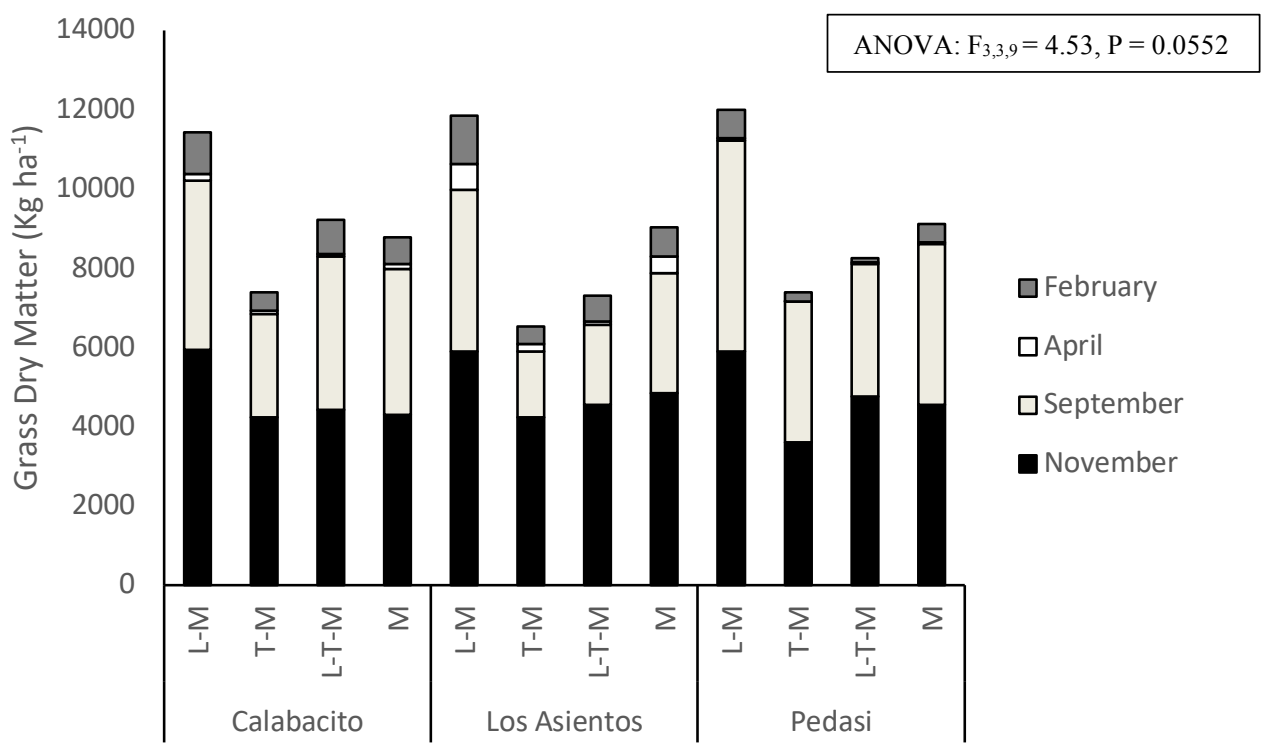

Fig. 11 Massai dry matter production sampled twice in the dry season and twice in the wet season of 2016 in the four planting regimes where grass was included at Calabacito, Los Asientos, and Pedasi in Los Santos, Panama. Values were $\log _{10}$ transformed for the analysis, but are depicted here as back-transformed values for ease of interpretation. 


\section{Shrub Dry Matter Production}

There were significant differences in $\log _{10}$ dry weight of forage between treatments $(\mathrm{P}=0.0208)$. Treatment $\mathrm{T}-\mathrm{M}$ produced significantly more $\mathrm{DM}$ than all other treatments. L. leucocephala produced significantly less fodder than T. diversifolia and Massai $(\mathrm{P}=0.0477)$. When $\mathrm{DM}$ values were back-transformed, least squares means ranged between $203.95 \mathrm{~kg} \mathrm{ha}^{-1}$ in L-L to $3120.59 \mathrm{~kg} \mathrm{ha}^{-1}$ in $\mathrm{T}-\mathrm{M}$. When seasons were summed, cumulative annual forage production was as much as 18,723 and $16,353.56 \mathrm{~kg}$ $\mathrm{ha}^{-1}$ in T-M and L-T-M, respectively. During the dry season, M produced 4.33, 10.95, and $13.7 \%$ less combined forage than L-M, L-T-M, and T-M, respectively (Table 6). There was a significant difference between seasons, with overall lower DM production during the dry season $(\mathrm{P}=0.0001)$ (Table 7$)$. In the dry season, shrubs made up $81.64 \%$ of the available forage in plots including both grasses and shrubs. In the rainy season, only $35.45 \%$ of available forage came from shrubs; the remainder was provided by grass (Fig. 12).

Growth rate of $A$. saman saplings

A. saman saplings exhibited a non-linear growth pattern, with variation among sites (Fig. 13). Final sapling height and diameter differed between sites, with saplings in Calabacito attaining noticeably smaller heights and diameters than those in Los Asientos and Pedasi (Table 7). At Calabacito, saplings growing in association with Massai attained the greatest heights and diameters. At Los Asientos, saplings in C performed consistently well, along with those in L and L-M, which initially grew the quickest, followed by a 
Table 6 Species contributions to total mean DM yield and total mean annual DM yield for each treatment over the three study sites.

\begin{tabular}{|c|c|c|c|c|c|}
\hline Treatment & Species & Dry & Wet & $\begin{array}{l}\text { Total Species } \\
\text { Contribution }\end{array}$ & $\begin{array}{c}\text { Annual Total (kg } \\
\left.\text { ha }^{-1}\right)\end{array}$ \\
\hline \multirow{3}{*}{$\mathrm{C}$} & Leucaena & -- & -- & -- & -- \\
\hline & Massai & -- & -- & -- & -- \\
\hline & Tithonia & -- & -- & -- & -- \\
\hline \multirow{3}{*}{ L-L } & Leucaena & $555 \pm 147$ & $669 \pm 188$ & 1224 & \multirow{3}{*}{1224} \\
\hline & Massai & -- & -- & -- & \\
\hline & Tithonia & -- & -- & -- & \\
\hline \multirow{3}{*}{ L-M } & Leucaena & $1236 \pm 133$ & $2179 \pm 218$ & 3415 & \multirow{3}{*}{14320} \\
\hline & Massai & $629 \pm 252$ & $10276 \pm 480$ & 10905 & \\
\hline & Tithonia & -- & -- & -- & \\
\hline \multirow{3}{*}{ L-T } & Leucaena & $1646 \pm 169$ & $2113 \pm 103$ & 3758 & \multirow{3}{*}{8618} \\
\hline & Massai & -- & -- & -- & \\
\hline & Tithonia & $2290 \pm 104$ & $2570 \pm 84$ & 4860 & \\
\hline \multirow{3}{*}{ L-T-M } & Leucaena & $1550 \pm 112$ & $2249 \pm 78$ & 3799 & \multirow{3}{*}{16354} \\
\hline & Massai & $751 \pm 163$ & $6698 \pm 311$ & 7449 & \\
\hline & Tithonia & $2419 \pm 189$ & $2687 \pm 111$ & 5105 & \\
\hline \multirow{3}{*}{$\mathrm{M}$} & Leucaena & -- & -- & -- & \multirow{3}{*}{7851} \\
\hline & Massai & $431 \pm 37$ & $7420 \pm 704$ & 7851 & \\
\hline & Tithonia & -- & -- & -- & \\
\hline \multirow{3}{*}{$\mathrm{T}-\mathrm{M}$} & Leucaena & -- & -- & -- & \multirow{3}{*}{18724} \\
\hline & Massai & $617 \pm 218$ & $6870 \pm 512$ & 7487 & \\
\hline & Tithonia & $5301 \pm 74$ & $5936 \pm 241$ & 11236 & \\
\hline \multirow{3}{*}{$\mathrm{T}-\mathrm{T}$} & Leucaena & -- & -- & -- & \multirow{3}{*}{11411} \\
\hline & Massai & -- & -- & -- & \\
\hline & Tithonia & $5100 \pm 57$ & $6312 \pm 80$ & 11411 & \\
\hline
\end{tabular}


Table 7 Least squares means of total dry matter production $\left(\mathrm{kg} \mathrm{ha}^{-1}\right)$ in each of the eight planting regimes, from each of three forage sources, and from dry (February and April) and wet (November and December) seasons.

\begin{tabular}{|c|c|c|c|c|c|c|c|c|c|c|}
\hline \multirow{3}{*}{ Treatment } & \multicolumn{7}{|c|}{ Treatment } & \multicolumn{3}{|c|}{ ANOVA } \\
\hline & $\mathrm{C}$ & $\mathrm{L}$ & $\mathrm{M}$ & $\mathrm{L}-\mathrm{T}$ & $\mathrm{T}$ & L-M & L-T-M & $\mathrm{T}-\mathrm{M}$ & $\mathrm{F}$ & $\mathrm{P}$ \\
\hline & $0(396)$ & $\begin{array}{l}204 a \\
(396)\end{array}$ & $\begin{array}{l}1309 b \\
(396)\end{array}$ & $\begin{array}{c}1436 b c \\
(396)\end{array}$ & $\begin{array}{l}1902 c \\
(396)\end{array}$ & $\begin{array}{c}2387 \mathrm{~cd} \\
(396)\end{array}$ & $\begin{array}{l}2726 d \\
(396)\end{array}$ & $\begin{array}{c}3121 \mathrm{e} \\
(396)\end{array}$ & 7.66 & 0.0208 \\
\hline \multirow[t]{2}{*}{ Fodder } & \multicolumn{2}{|c|}{ L. leucocephala } & \multicolumn{2}{|c|}{ T. diversifolia } & \multicolumn{2}{|c|}{ Massai } & & & & \\
\hline & \multicolumn{2}{|c|}{762 (243)a } & \multicolumn{2}{|c|}{$2038(243) b$} & \multicolumn{2}{|c|}{$2106(243) b$} & & & 5.26 & 0.0477 \\
\hline \multirow[t]{2}{*}{ Season } & & Dry & \multicolumn{4}{|c|}{ Wet } & & & & \\
\hline & & $938(256) \mathrm{a}$ & \multicolumn{4}{|c|}{$2332(256) \mathrm{b}$} & & & 38.28 & $<.001$ \\
\hline
\end{tabular}




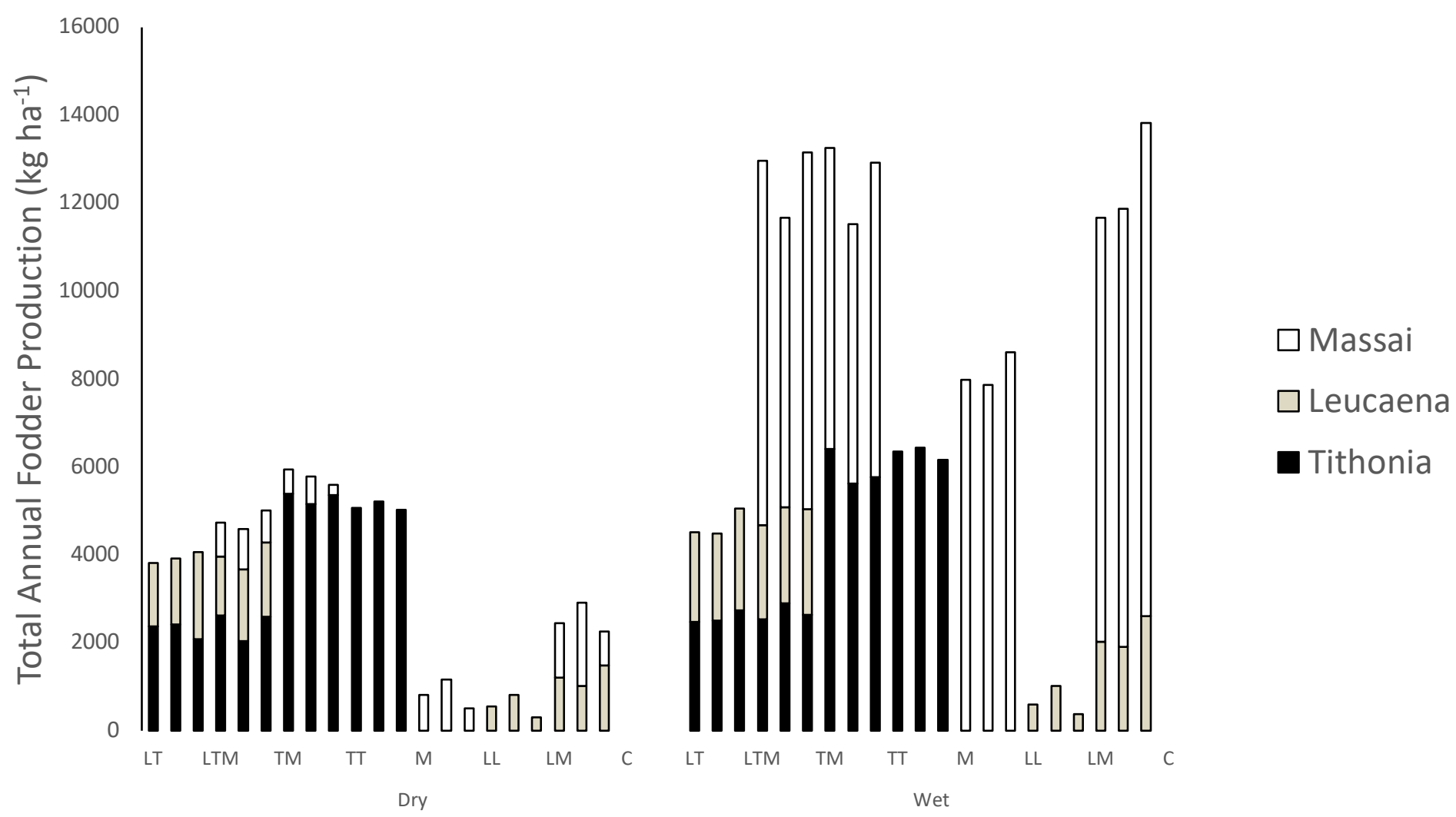

Fig. 12 Total annual DM forage production among the various planting regimes, including contributions from the grass Massai and the shrubs T. diversifolia and L. leucocephala on eight plots at the three sites Calabacito, Los Asientos, and Pedasi. 

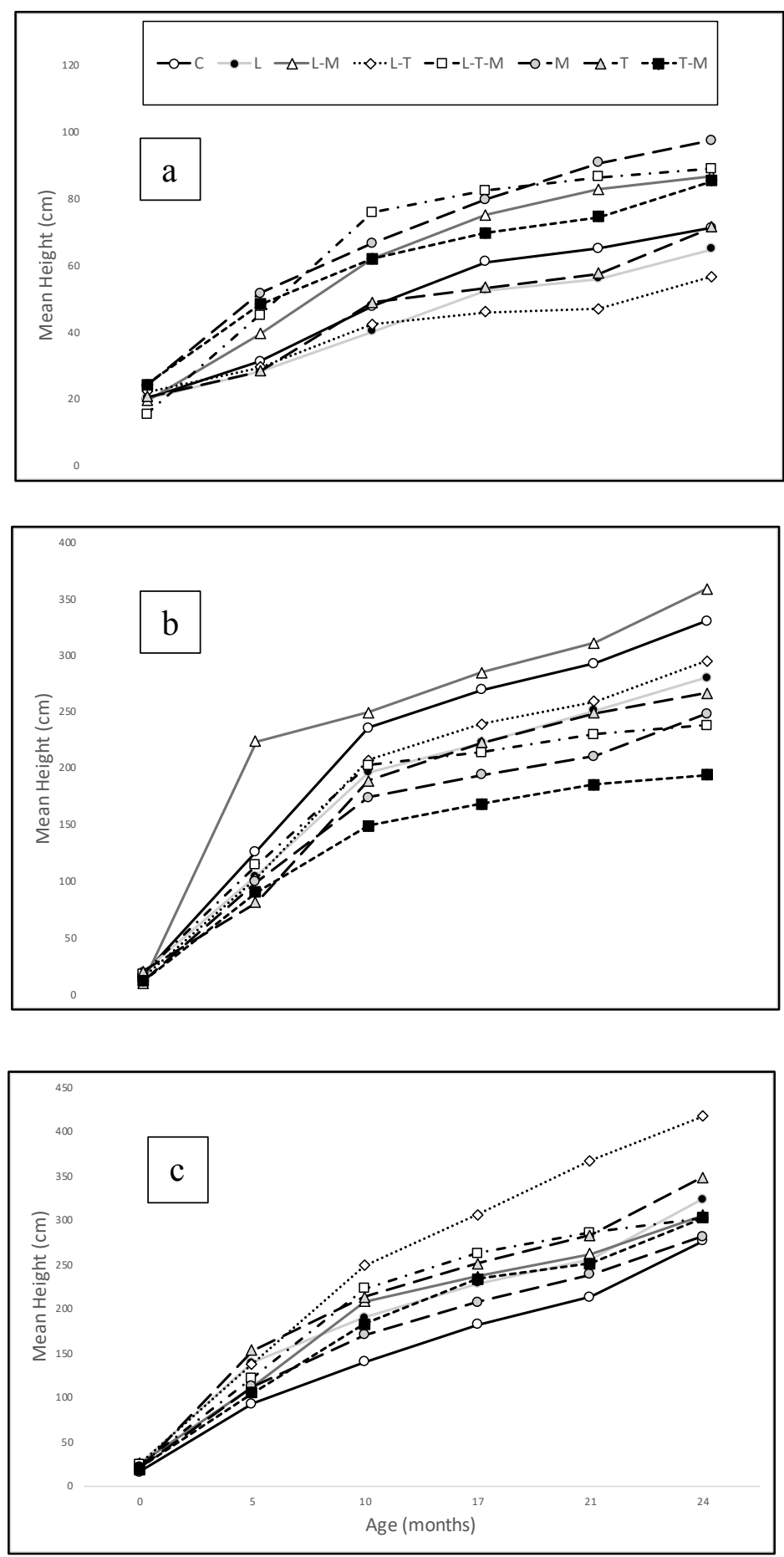

Fig. 13 Mean height of the five $A$. saman target saplings in association with the different planting regimes over the two-year period at the three sites a) Calabacito, b) Los Asientos, and c) Pedasi. 
reduction in growth rate. At Pedasi, saplings in L-T, T, and L attained greatest heights and diameters (Table 8). Despite this site having the lowest overall soil fertility, A. saman sapling growth in Pedasi outperformed all the others (Fig. 15). Consequently, there were no statistically significant differences observed between treatments for height $(\mathrm{P}=$ 0.7802) nor diameter $(\mathrm{P}=0.5798)$ absolute growth rate (AGR) (Table 9).

Table 8 A. saman sapling final height $(\mathrm{cm})$ and diameter $(\mathrm{cm})$ growing in association with eight different planting regimes on farms at Calabacito, Los Asientos, and Pedasi.

\begin{tabular}{lcccccc}
\hline \multicolumn{5}{c}{ Calabacito } & Los Asientos & \multicolumn{2}{c}{ Pedasi } \\
\hline \multirow{2}{*}{ Treatment } & Height & Diameter & Height & Diameter & Height & Diameter \\
& $71.28 \pm$ & & $329.94 \pm$ & & $276.62 \pm$ & \\
C & 2.71 & $1.524 \pm 1.36$ & 23.45 & $7.126 \pm 4.30$ & 12.83 & $5.118 \pm 5.02$ \\
& $64.82 \pm$ & & $280.26 \pm$ & & $323.66 \pm$ & \\
L & 10.67 & $1.417 \pm 1.71$ & 18.78 & $5.74 \pm 4.92$ & 16.74 & $5.3 \pm 3.94$ \\
& $86.86 \pm$ & & $358.66 \pm$ & & $305.16 \pm$ & \\
L-M & 8.89 & $1.96 \pm 1.25$ & 17.67 & $6.394 \pm 5.47$ & 25.78 & $5.358 \pm 3.19$ \\
& $56.46 \pm$ & & $294.68 \pm$ & & $416.94 \pm$ & \\
L-T & 5.28 & $1.404 \pm 1.41$ & 13.67 & $5.054 \pm 3.64$ & 25.44 & $6.644 \pm 8.05$ \\
& $88.9 \pm$ & & $237.86 \pm$ & & $301.82 \pm$ & \\
L-T-M & 8.62 & $1.668 \pm 1.49$ & 28.61 & $5.06 \pm 6.78$ & 22.47 & $5.078 \pm 3.07$ \\
& $97.34 \pm$ & & $248.06 \pm$ & & $281.76 \pm$ & \\
M & 7.02 & $1.898 \pm 1.35$ & 24.29 & $4.656 \pm 4.96$ & 25.85 & $5.23 \pm 3.75$ \\
& $71.34 \pm$ & & & $348.1 \pm$ & \\
T & 6.12 & $1.522 \pm 1.20$ & 21.57 & $4.88 \pm 3.81$ & 35.50 & $6.536 \pm 6.75$ \\
& $85.34 \pm$ & & $193.98 \pm$ & & $302.52 \pm$ & \\
T-M & 6.87 & $1.734 \pm 2.01$ & 14.80 & $3.448 \pm 2.25$ & 25.36 & $5.622 \pm 4.87$ \\
\hline
\end{tabular}

Although not significant, saplings in M and L-M had the greatest mean monthly height and diameter increment at Calabacito, particularly in the last two sampling periods. At Los Asientos, saplings in C, L, and L-M grew relatively quickly during the 
first two sampling periods and then later slowed their growth rate. Another nonsignificant, but important result to note is that L-T consistently had the highest mean monthly height and diameter increment in Pedasi, with the exception of the first 5 months, where $\mathrm{T}$ was greater (Figs. 15 and 16). Seasonal differences in growth were distinct, with significant differences occurring between all sampling periods with the exception of the first and second rainy seasons $(\mathrm{P}=0.870)$. There were no treatment*sampling period interactions for height nor diameter AGR (Table 9).

Table 9 ANOVA table of generalized linear mixed effects model results for the response parameters height and diameter, expressed as absolute growth rate (AGR, $\mathrm{cm}$ month $\left.^{-1}\right)$. Data was collected from July 2015 to August 2017 and only the top five "target" saplings were included in the analysis. The natural log of both parameters was used in the analysis.

\begin{tabular}{lcccc} 
Height (AGR) & Num DF & Den DF & F-value & P-value \\
\hline Treatment (Planting Regime) & 7 & 21 & 0.56 & 0.7802 \\
Sampling Period & 4 & 96 & 40.42 & $<.0001$ \\
Treatment*Sampling Period & 28 & 96 & 1 & 0.4767 \\
& & & & \\
Diameter (AGR) & 7 & 21 & 0.8 & 0.5798 \\
Treatment (Planting Regime) & 4 & 96 & 78.62 & $<.0001$ \\
Sampling Period & 28 & 96 & 0.57 & 0.9529 \\
Treatment*Sampling Period & & & & \\
\hline
\end{tabular}




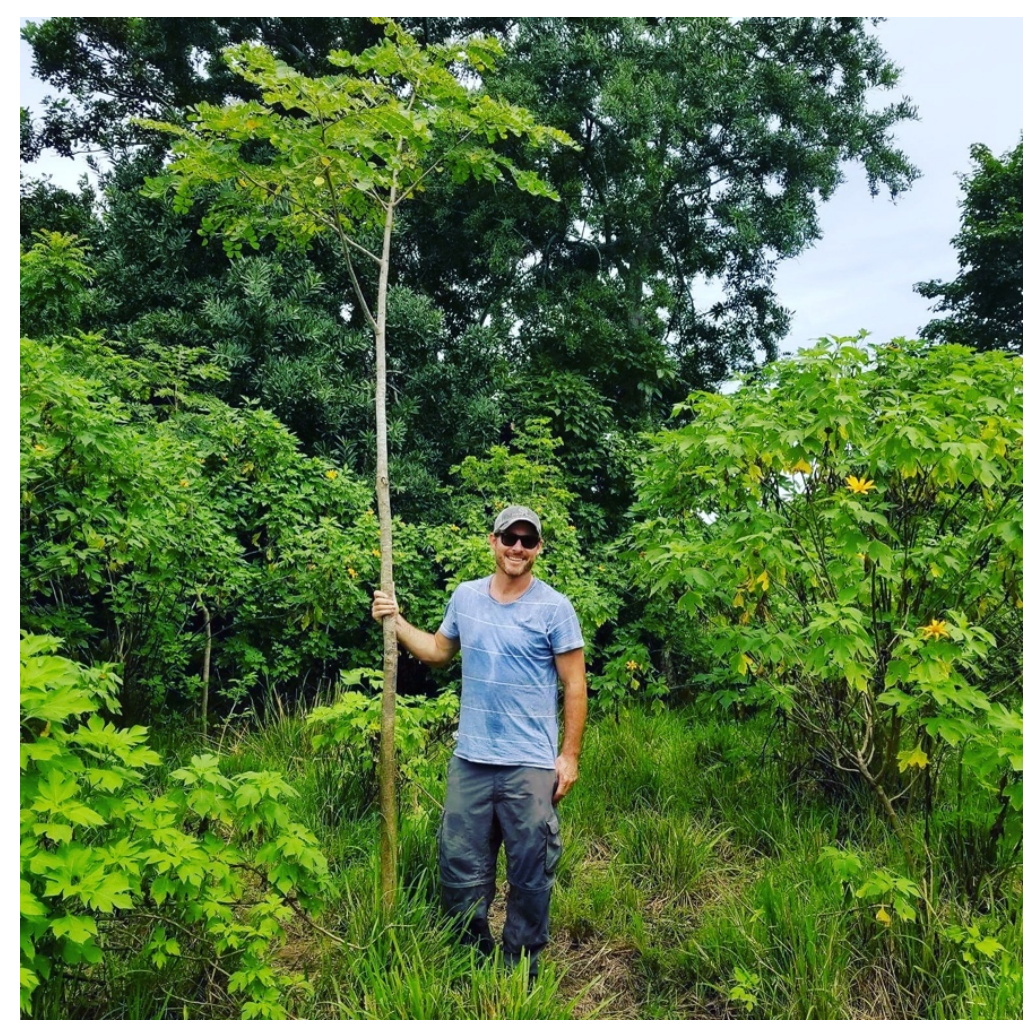

Fig. 14 An example of one of the several A. saman seedlings growing over $3 \mathrm{~m}$ tall after two years of growth in the T-M treatment at Pedasi, Los Santos, Panama.

Survival of $A$. saman seedlings

Seedling survival was assessed in July 2016, one year after planting, and then again in August of 2017. In 2016, 546 of 600 seedlings remained, amounting to an overall survival rate of $95 \%, 91.5 \%$, and $87.5 \%$ of seedlings survived at Pedasi, Los Asientos and Calabacito, respectively (Table 10). In August of 2017, 506 out of 600 seedlings remained, with an overall survival rate of $84.33 \%$. 

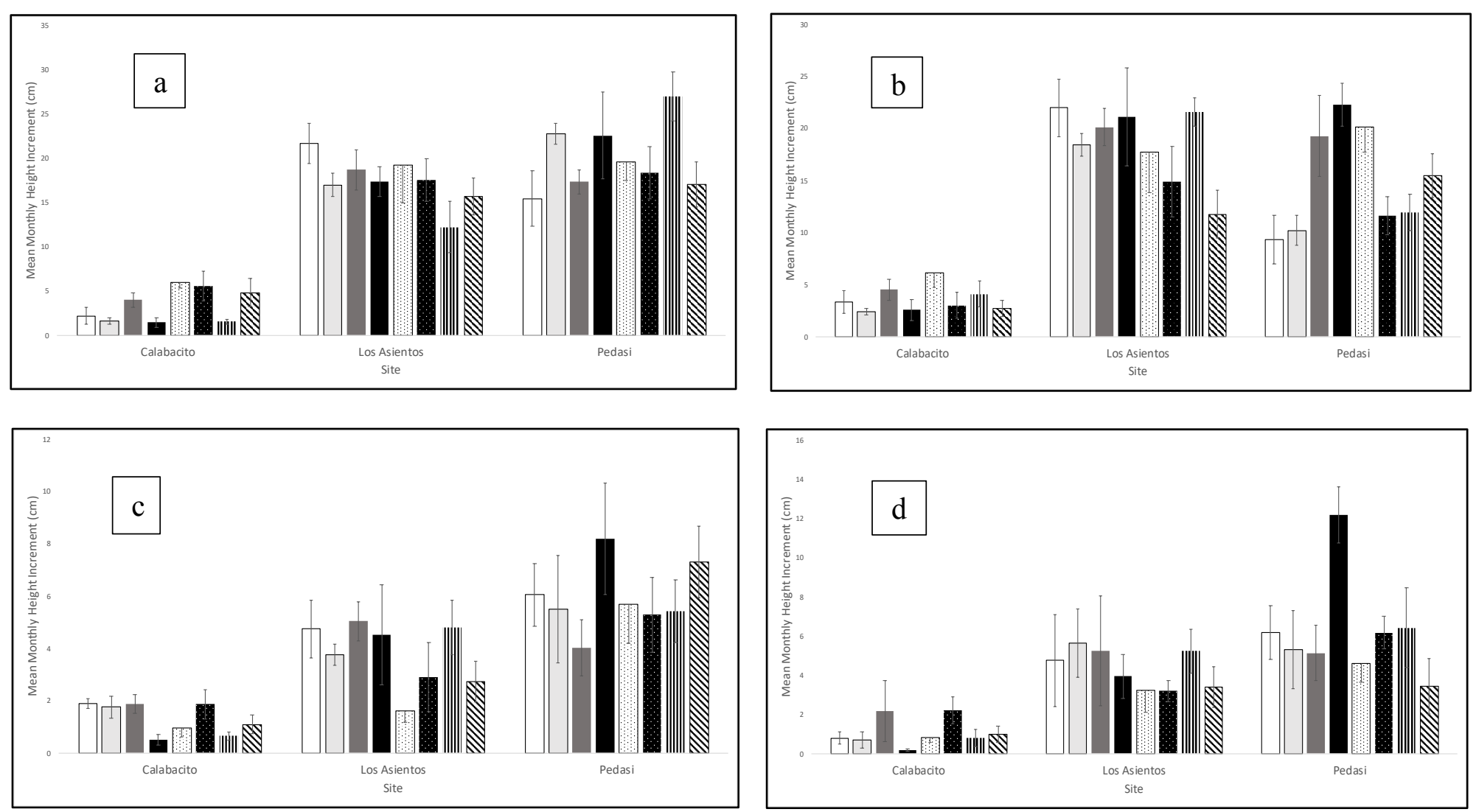

Treatment (Planting Regime)

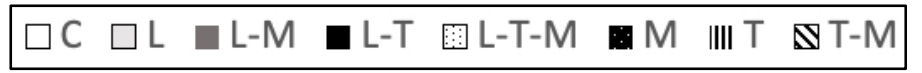

Fig. 15 Mean monthly height increment (cm) of the target saplings during the periods from a) 0-5 months (wet), b) 5-10 months (dry), c) 10-17 months (wet), and d) 17-21 months (dry) after tree planting. 

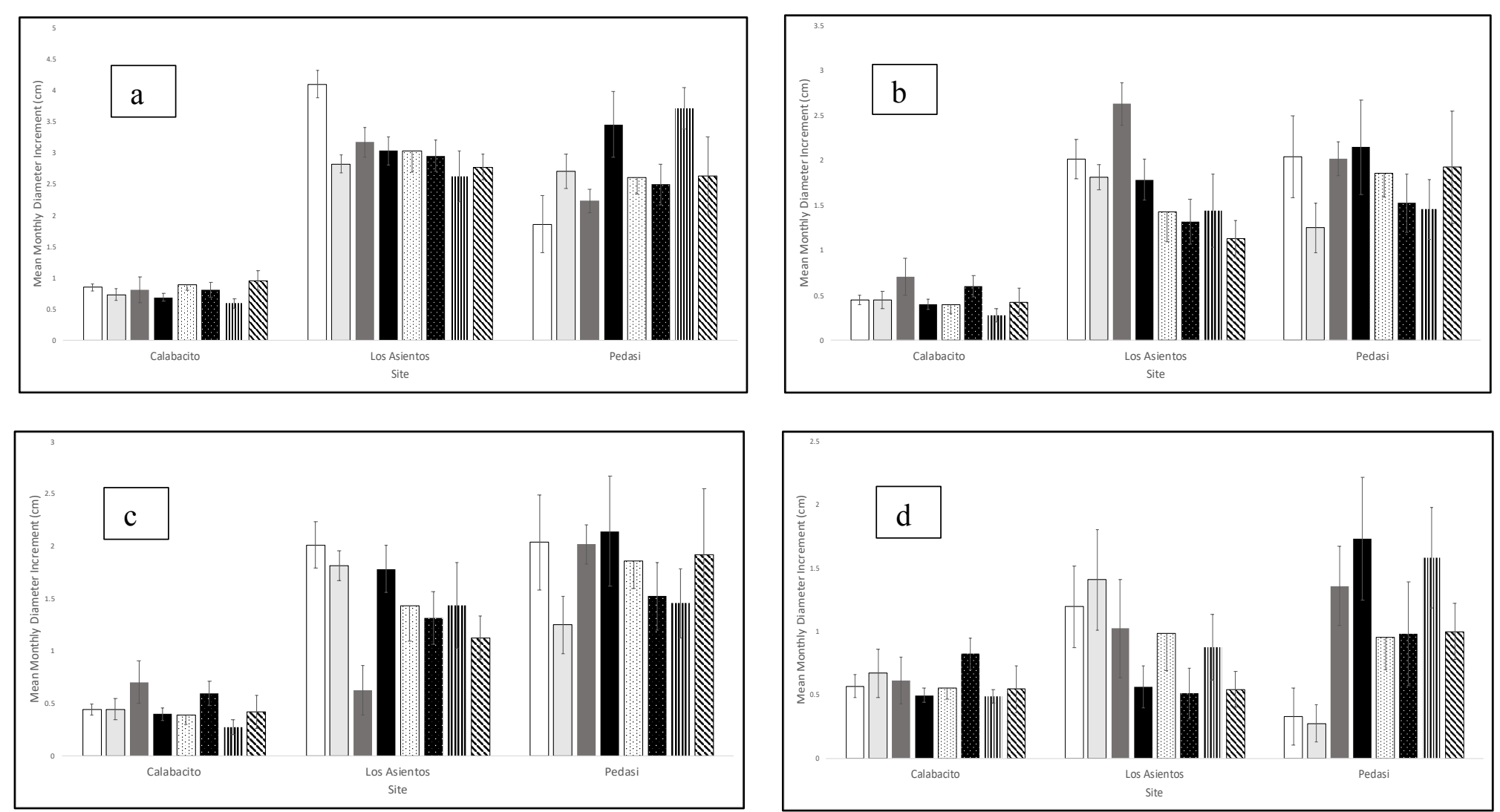

Treatment (Planting Regime)

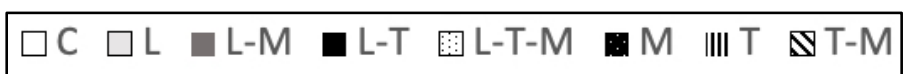

Fig. 16 Mean monthly root collar diameter increment $(\mathrm{cm})$ of the target trees during the periods from a) 0-5 months (wet), b) 5-10 months (dry), c) 10-17 months (wet), and d) 17-21 months (dry) after tree planting 
Table 10 Percentage of $A$. saman seedlings surviving in association with eight planting regime treatments at farms in Pedasi, Los Asientos, and Calabacito.

\begin{tabular}{lcccccc}
\hline & \multicolumn{2}{c}{ Pedasi } & \multicolumn{2}{c}{ Los Asientos } & \multicolumn{2}{c}{ Calabacito } \\
\cline { 2 - 7 } Treatment & 2016 & 2017 & 2016 & 2017 & 2016 & 2017 \\
\hline C & 80 & 68 & 100 & 96 & 84 & 68 \\
L & 88 & 84 & 96 & 96 & 88 & 80 \\
L-M & 100 & 100 & 40 & 40 & 84 & 76 \\
L-T & 92 & 92 & 100 & 100 & 92 & 80 \\
L-T-M & 100 & 96 & 100 & 100 & 92 & 84 \\
M & 100 & 96 & 96 & 96 & 88 & 88 \\
T & 100 & 100 & 100 & 100 & 84 & 68 \\
T-M & 100 & 92 & 100 & 100 & 88 & 84 \\
\hline Year Average & 95 & 91 & 91.5 & 91 & 87.5 & 78.5 \\
Site Average & & 93 & & 91.25 & & 83 \\
\hline
\end{tabular}

There was no treatment effect on seedling survival $(\mathrm{P}=0.8442)$. Interestingly, lowest survival in Calabacito and Pedasi occurred in $\mathrm{C}$, the only treatment where seedlings were planted in isolation of neighboring plants. In Los Asientos, lowest survival was documented in L-M (Table 10). Month affected seedling survival, with significantly higher mortality during the dry season than during the rainy season $(\mathrm{P}=$ 0.0432). There were no significant interaction effects. 


\section{Discussion}

Soil chemical and Physical Properties

Our hypothesis predicting increased soil fertility in plots that included shrubs was supported. The data clearly suggest that the inclusion of perennial shrubs, and in some cases, perennial grasses, significantly increased soil fertility parameters over time. The macronutrients $\mathrm{N}, \mathrm{P}, \mathrm{K}$, and $\mathrm{Ca}$ all showed significant increases when associated with the shrubs L. leucocephala and T. diversifolia, however, we were unable to discern the relevant nutrient contributions provided by each shrub.

Significantly higher concentrations of ammonium in L-T, L-T-M, and L suggest that L. leucocephala may be provisioning plant available $\mathrm{N}$ to the surrounding soil. This result is similar to that presented by Mafongoya and Nair (1997), who showed that the incorporation of Cajanus cajans and L. leucocephala prunings into the soil released relatively large amounts of $\mathrm{N}$ that became available to surrounding Zea mays. Palm and colleagues (1997) claimed that tree prunings applied at 5 tons $\mathrm{ha}^{-1}$ can provide between 60 and $150 \mathrm{~kg} \mathrm{ha}^{-1}$ of $\mathrm{N}$, supporting Z. mays yield of up to 4 tons ha ${ }^{-1}$ without any added synthetic fertilizer.

The exact mechanism responsible for this increase in ammonium remains unknown, largely because this study involved periodic coppicing and the subsequent addition of organic leaf matter to the soil, two management techniques that act together to confound inquiries into mechanism. Coppicing has been shown to induce root die-back, followed by the subsequent release of N-rich exudates to the soil, while application of organic matter to the soil surface results in $\mathrm{N}$ transfer through decomposition and mineralization (Munroe and Isaac 2014). Further, some authors have speculated that the 
addition of organic matter or inorganic fertilizers to the soil can impede nodulation and nitrogen fixation in certain species (Kadiata 1997). Thus, it is impossible to conclude exactly what proportion of the recorded ammonium was contributed by leaf litter decomposition and mineralization.

Interestingly, the lowest recorded ammonium and nitrate concentrations were from treatment M, where no shrubs were present. Over the course of the study, the greatest increases in ammonium and nitrate were in L-T (1.01\%) and L-T-M (1.17\%). Some authors have speculated that there are likely synergistic effects when nitrogenfixing rhizobium bacteria (from L. leucocephala) and vesicular arbuscular mycorrhizal fungi (from Tithonia diversifolia) are combined. In a phosphate-deficient soil, De la Cruz and authors (1988) obtained little increase in the $\mathrm{N}$ per plant of A. auriculiformis, $A$. mangium and A. falcata from the inoculation with rhizobium alone, but found 8- to 25fold increases when inoculated both with rhizobium and selected vesicular arbuscular mycorrhizal (VAM) fungi.

Plant available $\mathrm{P}$ increased significantly in T-M, L-T-M, and L-T, indicating that T. diversifolia may be playing an important role in P provisioning. In a review of several agroforestry systems in Colombia, León and Osorio (2014) claimed that soil chemical changes from litterfall and turnover are typically not observed until between 6 and 13 years after tree establishment. However, this review did not consider biomass transfer systems, where leaf litter prunings are applied directly to the soil surface and sub-surface. Not only does $T$. diversifolia rapidly produce green leaf biomass high in foliar nutrients; it decomposes quickly after incorporation into the soil (Jama et al. 2000). This rate of 
litter turnover greatly enhances biogeochemical cycling, particularly during the wet season, and could be at least partially responsible for the observed increases in P.

Gachengo et al. (1998) applied T. diversifolia green biomass at 5 tons ha-1 ${ }^{-1}$ to maize fields in Kenya and showed that half the leaves decomposed in 1.1 weeks and that $\mathrm{N}$ and $\mathrm{P}$ were released immediately. In under one year, the amount of $\mathrm{N}$ and $\mathrm{P}$ supplied to surrounding maize was equivalent to the amount of commercial NPK fertilizer recommended, doubling maize yields in comparison to the unfertilized control. In a similar study, Mutuo (2000) failed to detect increased levels of microbial P in maize fields following the application of $T$. diversifolia green biomass at 1.8 tons ha ${ }^{-1}$. Mean $T$. diversifolia shrub biomass presented in our study measured 2.038 tons ha ${ }^{-1}$, all of which was returned to the soil. Differences in P response could be due to differences in the timing of litter application with the nutrient demands of the crop. Effectively synchronizing plant litter nutrient release with crop demands is extremely important for the successful application of biomass transfer systems.

Alternatively, elevated levels of soil plant available $\mathrm{P}$ could be attributed to belowground processes not explored here. Belowground associations with vesicular arbuscular mycorrhizal (VAM) fungi and plant-moderated alterations of the rhizosphere via root exudation of organic anions are other plausible explanations for elevated levels of plant available P (George et al. 2002). The increase in root surface area under intercropping systems allows for greater soil exploration, the modification of root distribution in response to nutrient availability (Cahill et al. 2010), and the ultimate enhanced uptake of $\mathrm{P}$ and other nutrients. 
Soil organic matter and total C increased moderately over time in all treatments except for $\mathrm{C}$, where the ground remained bare. This is not surprising, as bare ground is vulnerable to severe erosion and runoff, violating one of the central tenets of conservation agriculture. In 2017, treatments $\mathrm{M}$ and C differed significantly from L-T-M, suggesting that the contribution of both shrubs had an additive effect on SOM. This is not the first study concluding that the intercropping of fertilizer shrubs can have significant positive effects on SOM. In a study examining the intercropping of Gliricidia sepium with Zea mays in Southern Africa, Beedy et al. (2010) reported that 14 years after establishment, SOM was $12 \%$ higher in the Gliricidia intercrop compared to the Zea mays monoculture. Intercropping has also been shown to increase SOM decomposition, presumably through reduced SOM recalcitrance resulting from lower $\mathrm{C}: \mathrm{N}$ ratio, higher litter input and better $\mathrm{N}$ retention (Cong et al. 2015).

Our hypothesis predicting significantly lower bulk density in treatments with shrubs was only partially supported, because treatment $\mathrm{M}$ also reduced bulk density. These data indicate that the establishment of perennial vegetation, herbaceous or woody, is important in the reduction of bulk density. Other studies have reported significantly greater bulk density of soil planted in pasture grasses versus that of woody perennials (Belsky 1994; Staley et al. 2008; Orefice et al. 2017). It is possible that not enough time has passed since tree and shrub planting to observe noticeable bulk density declines in treatments including shrubs. Bulk density also has important implications for soil moisture, in that it directly influences the rate and conversion of precipitation into plant available soil water and other physical properties such as porosity and hydraulic conductivity (Li and Shao 2006). 


\section{Soil Volumetric Water Content}

Our hypotheses predicting greater VWC at deeper soil depths and during the wet season were supported. However, we did not find any treatment differences for VWC during either season. In March, the driest month, least square mean VWC from $20 \mathrm{~cm}$ depth was marginally greater in $\mathrm{C}$ and $\mathrm{M}$, but only for that depth. It could be possible that rooting depths of the trees and shrubs are greater than that of grasses, giving them access to moisture found at greater soil depths, depleting more of the moisture from that depth. When woody perennials are planted closely together in arid environments, their root systems tend to be highly plastic, favoring the diminishment of lateral spread, sending their roots deeper into the soil (Lehmann et al. 1998). During March and April, all Massai grasses had already lignified and yellowed, while foliage on the trees and shrubs remained green (Fig. 17).

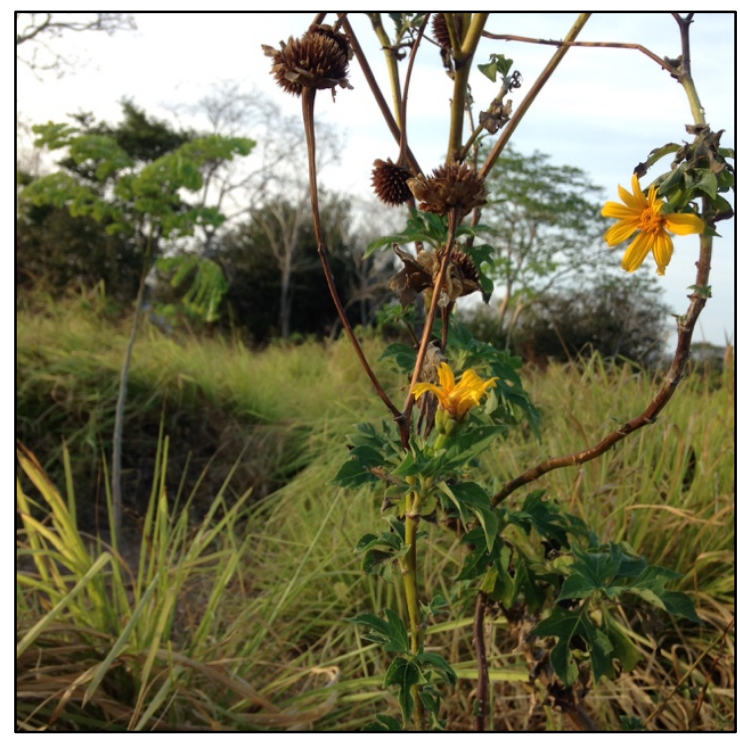

Fig. 17 The green leaves of T. diversifolia (foreground) and A. saman (background) contrasted with the yellowing tillers of surrounding Massai grass in March 2016 at the plantation in Pedasi. 


\section{Plant Moisture Stress}

Our hypothesis predicting seedling PMS to be affected by month was supported but we did not observe the treatment differences that we expected. The presence of multiple competing species in treatments including shrubs did not affect plant water availability. There was wide variation in treatment response to PMS across sites, which indicates that differences in physical soil structure and topography played an important role in water availability. Several studies have suggested that mixed-species plantings can actually reduce water competition and benefit plants in drought-impacted areas. One study showed that when the commercial timber tree Amarillo (Terminalia amazonia) was planted in monocultures, it was less tolerant of drought stress than when it was planted in mixed plots with the nitrogen fixing pioneer Cocobolo (Dalbergia retusa) (Craven et al. 2011). Another study in Panama showed that solitary tree saplings exhibited significantly higher $\delta^{13} \mathrm{C}$ values (measure of plant stress) than those surrounded by nitrogen-fixing and non-nitrogen-fixing companion plants. This may indicate increased water stress due to a more intense exposure to sunlight and higher temperatures in solitary individuals (Plath et al. 2010). Although we did not determine this to be true in our study, we did not find any evidence of drought stress in seedlings surrounded by neighboring shrubs and grasses.

\section{Massai DM Production}

Our hypothesis predicting significantly more grass DM production in all treatments with shrubs was not supported. Massai grasses growing in treatment L-M outperformed all other treatments, producing $39.3 \%$ more biomass than $\mathrm{M}$ and more than twice as much biomass than L-T-M and T-M. Reported DM yields for M. maximus and 
its cultivars vary widely, with open pasture wet season estimates ranging from $2,400 \mathrm{~kg}$ $\mathrm{ha}^{-1}$ (Brâncio et al. 2003) to as much as 20,900 $\mathrm{kg} \mathrm{ha}^{-1}$ for open pastures fertilized with 150 to $200 \mathrm{~kg} \mathrm{ha}^{-1}$ of nitrogen (Fernandes et al. 2014). These estimates depend greatly on site-specific climatic and edaphic conditions, management, and sampling protocol; thus, comparisons should be made cautiously. In a study examining the effects of the fertilizer shrub Erythrina poepiggiana on the commonly planted African grass Brachiaria brizantha, Bustamante and colleagues (1998) found that production of $B$. brizantha was $41 \%$ higher in silvopastoral systems in association with E. poepiggiana, which was pruned every 6 months, compared to production measured in B. brizantha monocultures. Several other studies looking at the effects of L. leucocephala on surrounding Massai production have either found no difference (Wilson 1998) or a reduction in grass dry matter production when compared with grass monocultures (Kumar et al. 2001). Both studies documented a significant reduction of grass DM production after three years, when the tree canopy began to close, shading out the grasses. It is important to reiterate that all eight of our plots contained $A$. saman seedlings, including the control, so Massai grasses were not free of competition like they were in the studies mentioned above. Investigating DM production of Massai monocultures adjacent to our test plots would enhance this study. Nevertheless, these data provide strong evidence that the facilitative effects of L. leucocephala are responsible for increased Massai production observed on these plots.

Massai DM production was lowest for plots including T. diversifolia. This result was surprising, considering that soils in these plots contained significantly greater concentrations of plant-available P. It is possible that competitive forces may have 
superseded more facilitative ones, resulting in grass productivity decline. T. diversifolia is known in many regions of the world as a weedy species, that has the potential to grow and spread rapidly. Even with periodic coppicing, foliage returned quickly, which occupied space and created shade (Fig. 18). Furthermore, several authors have reported that $T$. diversifolia may contain allelopathic chemicals that can impede the growth of other plants. Tongma and colleagues (2001) claimed that plants whose seeds were planted in soil where $T$. diversifolia had been growing for five years had significantly less germination, shoot growth, and root growth than those that were planted in a similar soil without the presence of $T$. diversifolia. They also concluded that $T$. diversifolia shrubs growing in water-limited environments contained greater amounts of allelopathic substances per dry weight than in the absence of water stress. Additionally, Otusanya and others (2007) found a significant reduction in the germination, growth, and dry matter production of Amaranthus cruentus by four different aqueous extracts containing $T$. diversifolia plant parts. Additional research is needed to determine which of these competitive forces is responsible for the observed reduction in grass biomass on these plots. 


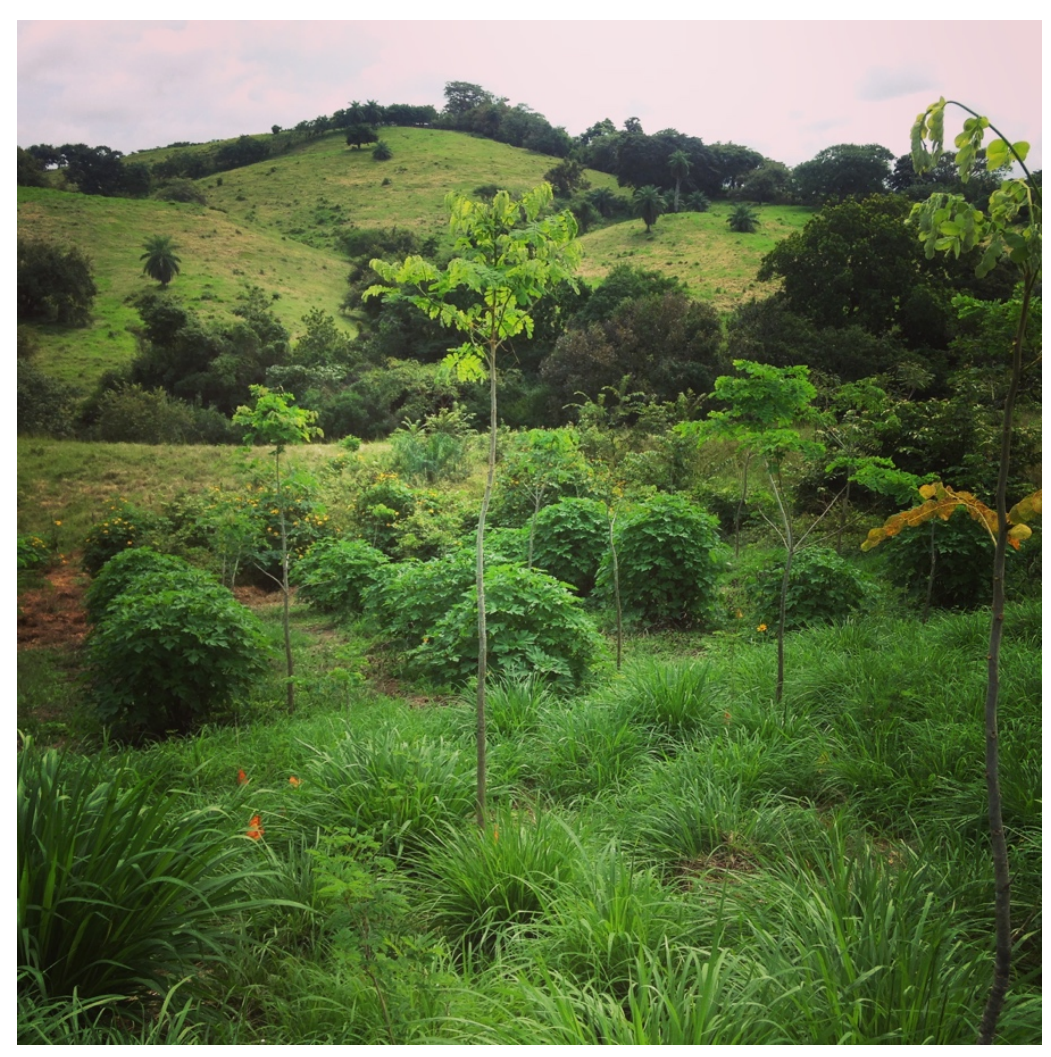

Fig. 18 Tithonia diversifolia shrubs (background) growing in the T-M plot at Los Asientos. Notice the severely reduced grass biomass in comparison to the M plot in the foreground.

When fertilizer shrub DM production was considered a supplemental addition to Massai forage, cumulative annual DM yielded more than 18 and 16 tons of fodder ha ${ }^{-1}$ in T-M and L-T-M, respectively. Despite these numbers, it is important to note how much of the biomass produced will actually be consumed by livestock (Devendra and Ibrahim 1999). Anecdotal reports from the Los Santos region suggest that cattle actively browse T. diversifolia only sparingly at the end of the dry season. This observation, coupled with the findings presented here showing a moderate reduction in Massai productivity in association with $T$. diversifolia, suggest that this species may be relatively unfit for threestrata silvopastoral systems. 


\section{Sapling Growth}

Growth results presented here (with the exception of Calabacito) compare similarly to those presented in the literature from the same region. Wishnie et al. (2007) reported a 2-year mean height of $364 \mathrm{~cm}$ and mean basal diameter of $7.55 \mathrm{~cm}$ for $A$. saman saplings planted in mixed species plantations in Los Santos, Panama. Another study from the Los Santos region reported a mean annual increment height and basal diameter of 143 and $3.84 \mathrm{~cm} \mathrm{yr}^{-1}$, respectively (Hall et al. 2011a). Our study recorded the following 2-year site averages for $A$. saman height and diameter: $77.79 \mathrm{~cm} / 1.64 \mathrm{~cm}$ (Calabacito); $276.25 \mathrm{~cm} / 5.294 \mathrm{~cm}$ (Los Asientos); 319.57 / $5.610 \mathrm{~cm}$ (Pedasi).

Our hypothesis predicting A. saman saplings to benefit in terms of growth from the presence of neighboring fertilizer shrubs was not supported. Treatments had no effect on sapling total height and diameter nor mean monthly height and diameter increment. This result is not dissimilar from that presented by Plath et al. (2010), who found that supplemental planting with companion species had neither a competitive nor facilitative effect on survival and growth performance of timber species. Conversely, Paul and Weber (2016) showed that when planted in association with Zea mays and C. cajan, the height increment of the timber species Astronium graveolens, Cedrela odorata, and Terminalia amazonia quadrupled that found in pure timber plantations. More time may be needed to form a clearer picture of how these planting regimes ultimately affect the growth of $A$. saman. It is likely that a facilitation effect could develop over a longer period of time. 


\section{Sapling Survival}

Our hypothesis predicting $A$. saman saplings to benefit from the presence of neighboring fertilizer shrubs in terms of survival was not supported. No treatment differences existed for survival, but several interesting patterns emerged. Sapling survival in Calabacito and Pedasi was lowest in treatment $C$, where saplings were planted in the absence of neighboring plants. Fertilizer shrubs may be protecting tree saplings from the intensity of sunlight and wind, reducing levels of evapotranspiration, and thus maintaining a more humid microclimate, creating a "nurse effect"' (Vandermeer 1989) for tree saplings. In Calabacito, tree saplings were particularly vulnerable to deer herbivory during the dry season both years, resulting in relatively inhibited survival and growth of saplings. All four treatments containing grasses had the highest rates of survival at this site. This may be an indication that established grasses provided a visual barrier that deterred browsing by deer. At Los Asientos, sapling survival was lowest in L$\mathrm{M}$, the treatment with the highest production of Massai. Management intervention was taken to prevent competition-induced mortality with the regular application of rodajeo (spot-ringed weeding), so it is unlikely that grass competition was the sole reason for mortality on this plot.

\section{Conclusion}

In conclusion, this experiment has demonstrated the successful integration of the native tree species $A$. saman with the non-native shrubs L. leucocephala and $T$. diversifolia. We have shown that with active management, $A$. saman tree saplings can be grown simultaneously with shrubs and grasses without negatively affecting growth and 
survival of all system components. Further, we have shown that the overall productivity of Massai pastures associated with $L$. leucocephala shrubs was enhanced, suggesting a potential facilitative interaction in these plots.

Two years after planting, the simulated silvopastures showed significant changes in several soil properties. Bulk density was significantly reduced in all plots except for C, where the soil was left bare. There were significant increases in $\mathrm{Ca}, \mathrm{K}$, ECEC and soil organic matter in plots that included shrubs throughout the course of the study. Additionally, plant available $\mathrm{N}$ and $\mathrm{P}$ increased in plots containing Leucaena and Tithonia shrubs, respectively.

There were no planting regime effects on soil water availability and $A$. saman sapling moisture stress. Additionally, A. saman growth and survival was not affected by planting regime, indicating that there were neither competitive nor facilitative effects strong enough to influence any of these factors, at least at this early stage in growth. Massai grass DM production showed a marginally significant positive response to the association with L. leucocephala, and although not significant, was reduced in the presence of $T$. diversifolia. Further research is needed regarding if and to what degree Massai grasses are affected by exposure to allelopathic chemicals released by this species. Although the findings presented here indicate facilitation by $A$. saman and $L$. leucocephala on surrounding pasture growth, plantations are still in their early stages, and results should be heeded with caution. 


\section{Management Recommendations}

It is expected that continued $A$. saman growth and canopy expansion will begin to limit pasture productivity, including that of the shade intolerant shrubs. Thus, periodic thinning of $A$. saman to a desired density is recommended and regular coppicing of shrubs will be needed to maintain nutrient levels and reduce spatial competition. Once introduced to the plots, cattle will help to control rampant growth of grasses and shrubs as well as recycle nutrients back to the soil via urine and manure. However, this is a very different kind of biomass transfer than the green mulching activities used in this study, and different results could be expected in the future.

One of the biggest drawbacks of this system is the labor required to periodically coppice shrubs and return green biomass to the soil. Moreover, the opportunity cost that is required to establish these systems can be prohibitive. During the early stages of silvopasture establishment, tree seedlings are particularly vulnerable to browsing and trampling by cattle. This makes the inclusion of livestock imprudent until tree saplings have grown above the browse line. A more practical alternative for producers would be to plant trees and shrubs in rows protected by polywire electric fencing with grasses planted on both sides. Shrubs should be coppiced several times and applied as green mulch to nearby grasses. Once the saplings reach an appropriate height, fencing should be removed to permit livestock to browse the shrubs, naturally coppicing them and returning nutrients to the soil.

Combining grasses with shrubs and trees creates three distinct foraging layers that not only increases system productivity but more importantly, mitigates forage losses during severe droughts and provides nutritional diversity to livestock. The increased 
adoption of similar agro-ecological systems will be critical for sustainable and environmentally sound livestock production in a future compromised by climate change. 


\title{
Chapter 4
}

\section{Initial Performance of Red Mulberry (Morus rubra L.) Under a Light Gradient: An Overlooked Alternative Livestock Forage?}

\begin{abstract}
Climate change creates much uncertainty for the future of agriculture, particularly due to an increase in summer droughts that result in the loss of range productivity. The integration of perennial shrubs into pasture is one way to diversify forage resources and compensate for losses caused by droughts during the summer forage gap. One species that has shown promise for use as woody fodder is white mulberry (Morus alba L.). While the yield and nutritional quality of $M$. alba has been widely studied, there remains a paucity of information for its native congener red mulberry (M. rubra). We report on the initial survival, growth, yield, and nutritive value of $M$. rubra seedlings planted under a cherrybark oak (Quercus pagoda) canopy at four overstory densities: 3×3m (D), 6x6m (S-D), 9x9m (S-O), and 12x12m (O), representing a light gradient. Global Site Factor (GSF), the proportion of global radiation under a plant canopy relative to that in an open area, ranged from 23.91 to $92.29 \%$. Despite summer drought conditions, $81.25 \%$ of seedlings survived, ranging from $70 \%$ in $\mathrm{D}$ to $90 \%$ in O. The odds of seedlings surviving in D were significantly lower than those of surviving in S-O and O. Seedlings expressed morphological plasticity with increased diameter growth, decreased specific leaf area, and increased DM yield as canopy openness increased. Seedlings appeared to reach a light saturation point somewhere between 66.21 and 92.03\% Global Site Factor (GSF) in terms of DM yield, obtaining highest leafiness at $66.21 \%$ GSF. Nutritive value assessed during the summer forage slump surpassed the quality of many common pasture forages. Nutritive value did not differ significantly above $66.21 \%$ GSF in terms of CP and fiber fractions and did not differ significantly for any of the treatments in respect to digestibility (TDN and RFV). Our results indicate that $M$. rubra seedling survival, growth, productivity, and nutritive value can be optimized on this site at $66.21 \%$ GSF, an irradiance level that corresponds to an overstory planting density of $9 \times 9 \mathrm{~m}$ $\left(\sim 500\right.$ trees $\left.^{-1} \mathrm{a}^{-1}\right)$. Due to unseasonably high protein and mineral content with relatively low fiber fractions, M. rubra could serve as a highly nutritional supplemental forage to livestock in multistrata silvopastures during drought conditions, but more research is needed to determine seedling response to repeated defoliation events.
\end{abstract}

Key words: Tree-shrub interactions, multi-strata agroforestry, forage production, silvopasture 


\section{Introduction}

The climate of the central United States has changed measurably over the last half century and significant changes in temperature and precipitation are predicted for the future. Extreme heat waves associated with less rainfall will become more frequent, resulting in an increase in the number of short-term summer droughts and precipitation is likely to arrive in the form of heavy rains (Dai 2013; Trenberth et al. 2014). Climate change creates uncertainty for the future of agriculture in the Midwest and will likely have far-reaching consequences for animal production through its effects on forage and range productivity (FAO 2009). Higher temperatures tend to lower feed intake and feed conversion rates (Rowlinson 2008) and increased drought frequency may decrease range production, forage longevity, and the availability of feedstock for the winter.

In Missouri, climate change has already had demonstrable effects on livestock production. In August of 2012, 93\% of the state experienced extreme drought (D3) conditions, creating pasture deficits and dwindling hay supplies that forced many cattle ranchers to sell their herds (Gustin 2012). Estimated financial losses to livestock and poultry operations were more than $\$ 547$ million (Nixon 2013). In the summer of 2018, an extreme drought (D3) plagued 19\% of Missouri, resulting in $72 \%$ of cattle pastures rated as poor or very poor. Additionally, haymaking was cut short and hay prices skyrocketed to $\$ 165 \mathrm{Mg}^{-1}$ (Dailey 2018). To make matters worse, most of Missouri’s most widely used forage crop tall fescue (Festuca arundinacea) has become infected with the fungal endophyte Neotyphodium coenophialum, elevating body temperatures and respiratory rates in cattle, making animals more vulnerable to heat-related stress (Roberts 2010). 
One way to mitigate the impacts of climate change is by intentionally integrating trees, forages, and livestock into one cohesive management unit. This agroforestry practice, known as silvopasture, has been shown to increase overall production, animal welfare, and environmental benefits (Broom et al. 2013; Jose et al. 2019). Silvopasture can reduce heat stress in livestock, increase weight gain, reduce calving difficulty, provide high quality forage, extend the grazing season, and increase the value of timber (McIlvain and Shoop 1971; McArthur 1991; Garrett et al. 2004; Kallenbach et al. 2006; Kallenbach 2009).

Trees and shrubs can also provide alternative and highly nutritious forage sources during critical periods. In other parts of the world, forage shrubs (also known as fodder shrubs) can be a strategic resource for farmers during the worst drought periods that often occur during the summer slump or forage gap. Some forage shrubs retain green foliage amidst even the harshest droughts due to their deep root systems that have specialized access to the water table. As the summer progresses, forage shrubs have been shown to lose nutritive value, digestibility and palatability at a slower rate than herbaceous forages (Talamuci and Pardini 1999), providing relatively high quality supplemental forage during these times. In Bali, Indonesia, the production of a shrub layer creates a three strata forage system that has resulted in an increase in stocking rates by one animal ha-1 and an increase in live weight gain by $153 \mathrm{~kg} \mathrm{ha}^{-1} \mathrm{yr}^{-1}$ (Devendra 2012). In Colombia, palatable nitrogen-fixing shrubs are planted at high densities amidst grasses and scattered trees and have increased milk yields by as much as 130\% (Murgueitio et al. 2011). Woody fodder has been reported to improve digestion, reduce parasitic infestation, and decrease methane emissions, but anti-nutritional components and toxins can limit their 
use (Vandermeulen et al. 2018a). In the temperate Mediterranean region of Italy, Papanastasis and colleagues (2008) concluded that natural woody shrub communities can be browsed directly by livestock and used as supplemental feed reserves during critical forage shortages.

The use of woody trees and shrubs for livestock fodder in the United States has been limited primarily due to a relatively limited plant selection and existing cultural and behavioral norms. Temperate regions lack the diversity of nutritious, nitrogen fixing woody plants that are used readily for fodder in the tropics. The few trees that produce palatable fodder only do so during the growing season when highly preferred herbaceous forage is available, unless compromised by extreme weather. In the winter, dried grasses and legumes in the form of hay are used as a primary feed source.

Orefice and colleagues (2016) surveyed landowners practicing hardwood silvopasture in the Northeastern U.S. and concluded that farmers valued trees for multipurpose uses. When asked for their opinion on important areas for future silvopasture research, a popular response was to further investigate the quality, selection, and management of plants serving as potential forage alternatives. Three out of 20 studied farms were managing woody browse as a component of forage in their silvopastures, but no specifics were provided in terms of species preferences.

In spite of these barriers, several perennial species have shown potential to provide woody fodder in temperate silvopastoral systems, including willow (Salix spp.) (Moore et al. 2003; Pitta et al. 2005), osage orange (Forwood and Owensby 1985), bristly locust (Burner and Burke 2012), and mulberry (Morus spp.). White mulberry (Morus alba), widely known for its use as a fodder for silk worm cultivation in Asia, can 
produce higher quantities of digestible nutrients than most traditional forages (Sánchez 2000). Its leaves are highly palatable and digestible (70-90\%) with a protein content varying from $15-28 \%$ and relatively low fiber and tannin contents, establishing its potential as a strategic forage source in temperate as well as tropical regions of the world (Sharma and Zote 2010). The optimum temperature for white mulberry biomass yield is reported to be $32{ }^{\circ} \mathrm{C}$ (Fukui 2000), within a range of temperatures that corresponds with the summer forage slump in Missouri. Both ruminants and monogastrics are known to consume the leaves of M. alba by either directly browsing the shrub or more commonly by ingesting clippings that are cut and carried to the location of the animal. Mulberry leaves can be used in poultry production and provide a valuable source of vitamin A due to their high carotene content. Moreover, pigs relish the maturing fruits which are relatively high in protein, readily devouring them throughout the summer (Shepard 2013).

M. alba was introduced to North America from East Asia in the 1600s and has since become naturalized in eastern North America. Although genetically differentiated from its native, shade tolerant congener red mulberry (Morus rubra), M. alba poses a growing threat to M. rubra trees throughout the eastern and central United States through competition and hybridization (Burgess and Husband 2006). This is concerning, considering this species' vital importance to native wildlife. One study in Arkansas reported 32 species of native songbirds foraging on red mulberry fruits over a 67 -hour period (Kannan 2018). The planting of M. rubra in temperate silvopastures could be an effective means of restoring this native species while provisioning fruit and fodder to livestock during the summer forage gap. While the yield and nutritional quality of $M$. 
alba has been widely studied (Sánchez 2000), there remains a paucity of information in this capacity for M. rubra.

A number of studies have been published on the growth and nutritional response of herbaceous forages to different shade intensities with implications for silvopasture (Lin et al. 2001, Belesky 2005, Buergler et al. 2006, Kallenbach et al. 2006). However, there is limited data available on how shade affects the survival, growth, yield, and nutritive content of naturally occurring understory woody shrubs, largely because they have not been viewed as a forage resource for livestock in the United States.

\section{Objectives}

The objectives of this study were to: 1) Establish plantings of M. rubra seedlings under four different overstory densities: 3x3m (D), 6x6m (S-D), 9x9m (S-O), and $12 \times 12 \mathrm{~m}(\mathrm{O})$ of cherrybark oak (Quercus pagoda), 2) quantify understory light levels with the use of hemispherical photography, 3) compare M. rubra survival among treatments, 4) evaluate differences in $M$. rubra growth rate by measuring height (cm), root collar diameter $(\mathrm{mm})$, crown width $(\mathrm{cm})$, and specific leaf area $\left.\left(\mathrm{SLA} ; \mathrm{cm}^{2} \mathrm{~g}^{-1}\right), 5\right)$ estimate differences in $M$. rubra stem and leaf dry matter yield, and 6) evaluate differences in $M$. rubra leaf nutritive value.

We hypothesized that M. rubra survival would be greatest in open areas. Although M. rubra is a shade tolerant species, it should reach its full photosynthetic potential in open sunlight and achieve greatest growth rates and dry matter yield in treatment $\mathrm{O}$. We hypothesized that SLA would be greatest in treatment D due to morphological differences stimulated by lower light levels. We expected M. rubra leaf 
nutritive value to increase as understory light levels decreased, predicting highest values for total digestible nutrients (TDN) and crude protein (CP) content and lowest values for the fiber fractions acid detergent fiber (ADF) and neutral detergent fiber (NDF) in D.

\section{Materials and Methods}

Study Site

This study was conducted at the Horticulture and Agroforestry Research Center (HARC) in New Franklin, Missouri (longitude $92^{\circ} 44^{\prime}$ W; latitude $39^{\circ} 01^{\prime} \mathrm{N}$ ). In November of 1997, an area encompassing 96,000 $\mathrm{ft}^{2}$ ( $\sim 2.2$ acres) on the southern border of the farm was planted in cherrybark oak (Quercus pagoda) seedlings at four different densities (Fig. 1). The soil type at this location is a Menfro silt loam (Fine-silty, mixed, superactive, mesic Typic Hapludalfs) and is well-drained. The soil is relatively fertile (Table 1) with textures ranging from loam to silt loam and an average soil $\mathrm{pH}$ of 5.01 ( \pm 0.16). Historic mean annual precipitation and temperature was $94.31 \mathrm{~cm}$ and $12.3^{\circ} \mathrm{C}$, respectively, compared to 85.8 and $13.37^{\circ} \mathrm{C}$ for the overall mean of data collected in 2016, 2017, and 2018 (Table 2). Mean monthly values are displayed for each year (Fig. 2).

Experimental Design

A randomized complete block design was used with overstory tree density as the treatment with two replications. Overstory $Q$. pagoda were planted at three different densities: $3 \times 3 \mathrm{~m}, 6 \times 6 \mathrm{~m}, 9 \times 9 \mathrm{~m}$, and $12 \times 12 \mathrm{~m}$ spacing between trees. Hereafter, 


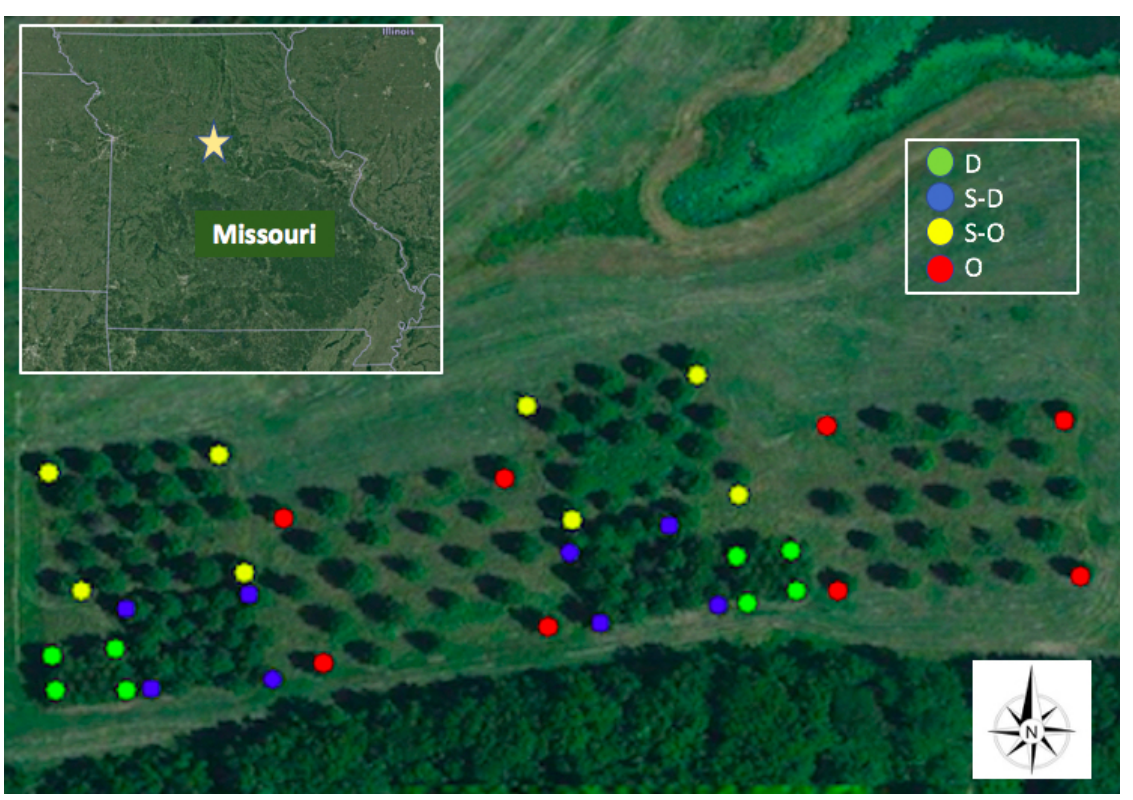

Fig. 1 Randomized complete block design with four cherrybark oak (Quercus pagoda) overstory tree spacings: D (3x3m), S-D (6x6m), S-O (9x9m), and O (12x12m) at the Horticulture and Agroforestry Research Center (HARC) in New Franklin, Missouri. Twenty red mulberry (Morus rubra) seedlings were planted on 3x3m spacings in the understory of each plot.

treatments will be referred to as dense (D), semi-dense (S-D), semi-open (S-O), and open (O) for convenience. Diameter at breast height $(\mathrm{DBH} ; \mathrm{cm})$ was measured for all overstory Q. pagoda trees to calculate stand basal area and quadratic mean diameter (Table 3 ). Twenty M. rubra seedlings were planted on a $3 \times 3 \mathrm{~m}$ spacing in the understory of each plot, which differed in size according to overstory tree spacing (Fig. 3). Seedlings were protected with plastic tubing and measured periodically throughout the study (described below). 
Table 1 Chemical soil properties for composite samples collected in May of 2018.

\begin{tabular}{|c|c|c|c|c|c|c|c|c|}
\hline Treatment & $\mathrm{pH}$ & N.A. & $\mathrm{OM}$ & Bray I P & $\mathrm{Ca}$ & $\mathrm{Mg}$ & $\mathrm{K}$ & CEC \\
\hline $\begin{array}{l}\text { Overstory Tree } \\
\text { Spacing }(\mathrm{m})\end{array}$ & & $\begin{array}{c}\text { Meq } \\
100 \mathrm{~g}^{-1}\end{array}$ & $\%$ & $\mathrm{Lb} \mathrm{Ac}^{-1}$ & $\mathrm{Lb} \mathrm{Ac}^{-1}$ & $\mathrm{Lb} \mathrm{Ac}^{-1}$ & $\mathrm{Lb} \mathrm{Ac}^{-1}$ & $\begin{array}{c}\text { Meq } \\
100 \mathrm{~g}^{-1}\end{array}$ \\
\hline $3 \times 3$ & $\begin{array}{l}4.95 \pm \\
0.15\end{array}$ & $\begin{array}{l}4.75 \pm \\
0.25\end{array}$ & $\begin{array}{c}3.15 \pm \\
0.15\end{array}$ & $95 \pm 20$ & $2895 \pm 95$ & $\begin{array}{c}549.5 \pm \\
107.5\end{array}$ & $\begin{array}{c}528 \pm \\
154\end{array}$ & $\begin{array}{c}14.95 \pm \\
0.75\end{array}$ \\
\hline $6 \times 6$ & $\begin{array}{c}4.9 \pm \\
0.30\end{array}$ & $\begin{array}{l}4.75 \pm \\
1.25\end{array}$ & 3.750 .25 & $74 \pm 30$ & $\begin{array}{c}3068.5 \pm \\
247.5\end{array}$ & $\begin{array}{c}542.5 \pm \\
128.5\end{array}$ & $325 \pm 21$ & $\begin{array}{l}15.1 \pm \\
2.4\end{array}$ \\
\hline $9 \times 9$ & $\begin{array}{l}4.95 \pm \\
0.15\end{array}$ & $5 \pm 0.50$ & $\begin{array}{l}4.35 \pm \\
0.15\end{array}$ & $\begin{array}{c}92.5 \pm \\
26.5\end{array}$ & $\begin{array}{c}3363.5 \pm \\
121.5\end{array}$ & $684 \pm 11$ & $460 \pm 19$ & $\begin{array}{c}16.85 \pm \\
0.25\end{array}$ \\
\hline $12 \times 12$ & $\begin{array}{c}5.25 \pm \\
0.05\end{array}$ & $4 \pm 0.00$ & $\begin{array}{c}4.3 \pm \\
0.10\end{array}$ & $\begin{array}{c}56.5 \pm \\
7.5\end{array}$ & $\begin{array}{c}2756.5 \pm \\
16.5\end{array}$ & $479 \pm 12$ & $\begin{array}{c}431.5 \pm \\
4.5\end{array}$ & $\begin{array}{c}13.45 \pm \\
0.05\end{array}$ \\
\hline
\end{tabular}


Table 2 Precipitation $(\mathrm{cm})$ and mean monthly temperature $\left({ }^{\circ} \mathrm{C}\right)$ at the Horticulture and Agroforestry Research Center (HARC) in New Franklin, Missouri. Source: NOAA Midwestern Regional Climate Center.

\begin{tabular}{ccc}
\hline Year & Precipitation $(\mathbf{c m})$ & Temperature $\left({ }^{\circ} \mathbf{C}\right)$ \\
\hline 2016 & 93.71 & 13.51 \\
2017 & 85.62 & 13.26 \\
2018 & 78.08 & 13.32 \\
\hline 3-year Mean & 85.80 & 13.36 \\
\hline
\end{tabular}

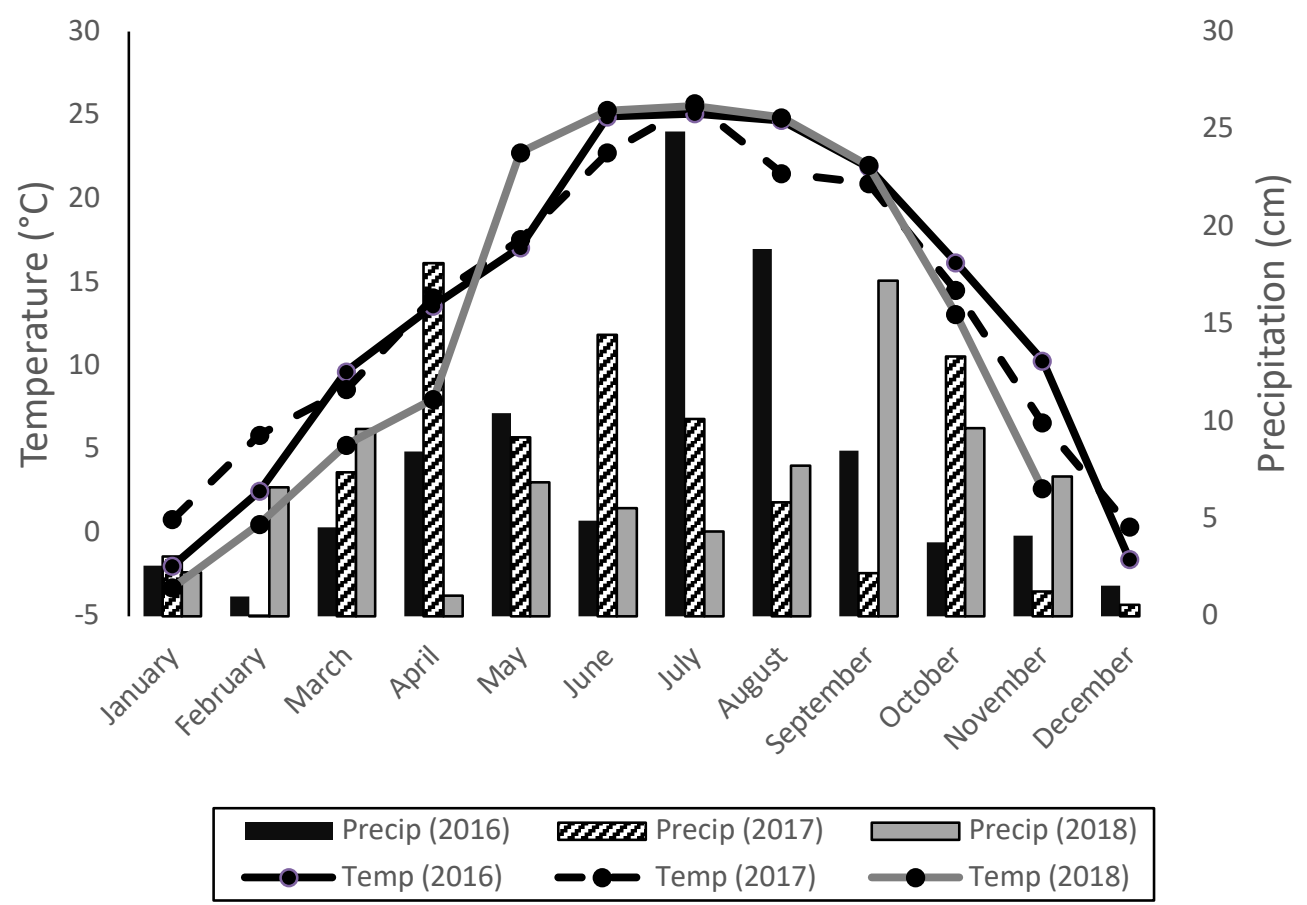

Fig. 2 Mean monthly precipitation $(\mathrm{cm})$ and temperature $\left({ }^{\circ} \mathrm{C}\right)$ for three years $(2016-$ 2018) at the Horticulture and Agroforestry Research Center (HARC) in New Franklin, Missouri. Source: NOAA Midwestern Regional Climate Center. 

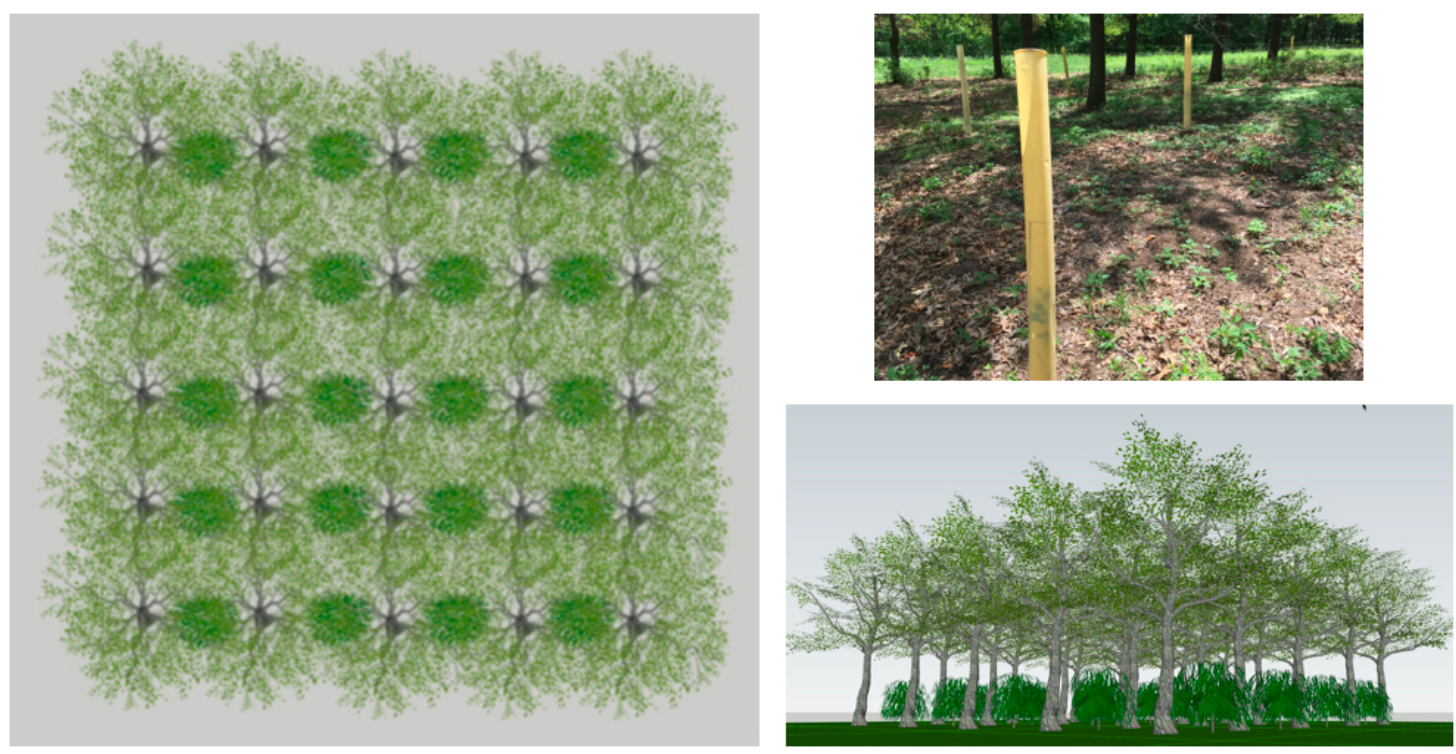

Fig. 3 Planting arrangement of the twenty red mulberry seedlings planted per treatment. Seedlings were planted on a $3 \times 3 \mathrm{~m}$ spacing under four different densities of cherrybark oak trees.

Table 3 Overstory composition with four planting densities in a 21-year old cherrybark oak (Quercus pagoda) plantation at the Horticulture and Agroforestry Research Center (HARC) in New Franklin, Missouri.

\begin{tabular}{ccccc}
\hline & & & & \\
Treatment & $\mathrm{D}$ & $\mathrm{S}-\mathrm{D}$ & $\mathrm{S}-\mathrm{O}$ & $\mathrm{O}$ \\
\hline & & $269 \pm$ & & \\
Trees ha $^{-1}$ & $551 \pm 10$ & 10.64 & $148 \pm 3.55$ & $91 \pm 3.32$ \\
& & $39.53 \pm$ & & $44.45 \pm$ \\
DBH (cm) & $28.47 \pm 1.50$ & 1.86 & $40.72 \pm 2.71$ & 1.44 \\
& & $33.39 \pm$ & & $14.34 \pm$ \\
Basal Area (m ha $\left.^{-1}\right)$ & $36.69 \pm 3.04$ & 1.33 & $20.67 \pm 2.71$ & 0.66 \\
Quadratic Mean Diameter & & $39.75 \pm$ & & $44.66 \pm$ \\
$(\mathrm{cm})$ & $29.11 \pm 0.41$ & 0.03 & $42.07 \pm 0.39$ & 0.31 \\
& & $46.28 \pm$ & & $92.29 \pm$ \\
Global Site Factor $(\%)$ & $23.91 \pm 3.51$ & 4.11 & $71.38 \pm 6.08$ & 2.81 \\
\hline
\end{tabular}

Means and standard error are reported. Global Site Factor is the percentage of total incident solar radiation reaching the understory canopy. 


\section{Understory Light Environment}

Light quantity was determined by measuring solar transmission radiation with hemispherical photography. Upward hemispherical images were photographed in the late summer of 2017 and the winter of 2018 using a Cannon EOS Rebel with an Opteka Vortex Fisheye Lens. Images were taken $1 \mathrm{~m}$ above the ground on a tripod equipped with a Delta-T devices mount used for horizontal leveling and north-south orientation of the camera. Measurements were taken at dawn to maximize light evenness. Three photographs were taken at the middle and corners of each plot with automatic exposure compensation and bracketing at $-2.0,-1.0$, and 0 . This was done to mitigate the effects of over-exposure that can result from using the automatic exposure in dense canopies. Images were analyzed with Hemiview software (Delta-T Devices Ltd., Cambridge,

U.K.), which classifies pixels into two classes: open sky and obstructed sky. The software calculates the global site factor (GSF), which is the sum of direct and diffuse radiation (excluding reflected radiation) entering through canopy openings as a proportion of the amount of radiation that would fall on the same point given no overhead obstructions over the course of a year (Griscom et al. 2009). Values range from 0 to 1, which 0 being no radiation (complete sky obstruction) and 1 being the radiation for an open location, where the sky is completely visible (Rich et al. 1999).

\section{Soil Properties}

Soil samples were collected preliminarily to confirm that all plots were relatively homogeneous. Twenty randomly distributed soil samples $(200 \mathrm{~g})$ were collected on a zig- 
zag path at $0-15 \mathrm{~cm}$ depth with an augur from each plot and analyzed for chemical and physical properties at the University of Missouri’s soil testing laboratory.

Growth, Specific Leaf Area, and Dry Matter Yield

A total of 160 comparably sized $(\sim 30 \mathrm{~cm})$ M. rubra bare root seedlings were purchased from Forrest Keeling Nursery in October, 2015, refrigerated throughout the winter and planted in early May, 2016. Twenty seedlings were planted in four rows (five per row) on a $3 \mathrm{~m} \times 3 \mathrm{~m}$ spacing in the understory of each treatment (Fig. 3). All plots were fertilized after planting using a compound fertilizer $(12: 24: 12 \mathrm{~N} / \mathrm{P} / \mathrm{K})$ at a rate of $180 \mathrm{~kg} \mathrm{ha}^{-1}$. In May of 2018, two years after seedling establishment, we broadcast seeded Orchardgrass (Dactylis glomerata) and Panicled Tick-trefoil (Desmodium paniculatum) to establish forages at the ground level. Due to a particularly dry spring and lack of irrigation, the forage stand failed to establish. Instead, a variety of broadleaf weeds emerged, including pokeweed (Phytolacca americana), ragweed (Ambrosia spp.), smartweed (Polygonum), beggar-ticks (Bidens pilosa), ironweed (Vernonia fasciculata), bush honey suckle (Lonicera maackii), poison ivy (Taxicodendron radicans) and some white clover (Trifolium repens) and tall fescue (Festuca arundinacea) that remained in the seedbed. It is important to note that the establishment of a ground forage component is necessary and critical to the success of any silvopasture operation. Time constraints prohibited re-seeding of ground forages and the assessment of interactions between woody and herbaceous components.

For the growth parameters height $(\mathrm{cm})$, diameter $(\mathrm{mm})$, crown width $(\mathrm{cm})$, specific leaf area $\left(\mathrm{cm}^{2} \mathrm{~g}^{-1}\right)$, and dry matter yield $\left(\mathrm{kg} \mathrm{ha}^{-1}\right)$, we used a commonly applied 
methodology known as the "top height tree collective" (Pretzsch 2009). This approach considers only the five most vital seedlings in each plot as targets for analysis; thus, the 10 tallest trees per treatment were selected as the sample population. These trees are most representative of those individuals that could potentially develop a competitive advantage over others. Additionally, the use of only five target trees avoids differences in means that could be caused by high differences in survival between treatments. Treatments with higher survival rates are likely to have wider ranges of heights and diameters than treatments with lower survival rates (Paul and Weber 2016).

M. rubra seedlings were measured with a metric tape and a vernier caliber to an accuracy of $1 \mathrm{~cm}$ and $0.1 \mathrm{~mm}$, respectively, twice in the summer of 2017 and twice in the summer of 2018 (Fig. 4). Height (cm), root collar diameter at ground level (from here also referred to as "diameter"; mm), and mean crown diameter (N-S, E-W; cm) were selected as the main indicators for tree growth. Parameters from the top five most vital seedlings were used for analysis.

Survival was recorded as either dead or alive and at the end of the first year, all dead seedlings were replaced with similar-sized bare root seedlings.

In mid-August of 2018, eight healthy leaves were collected from current year shoot growth on the five target trees. Specific leaf area $\left(\mathrm{SLA} ; \mathrm{cm}^{2} \mathrm{~g}^{-1}\right)$ was measured on a total of 40 leaves per plot using the Leafscan (C) iOS app. Leafscan is a new technology, but accuracy is reported to be good. Errors of between two and five percent have been recorded when correlated with the Licor LI-3100C leaf area meter (Leafscan 2019). All measurements were made in the field when leaves were still fresh. 

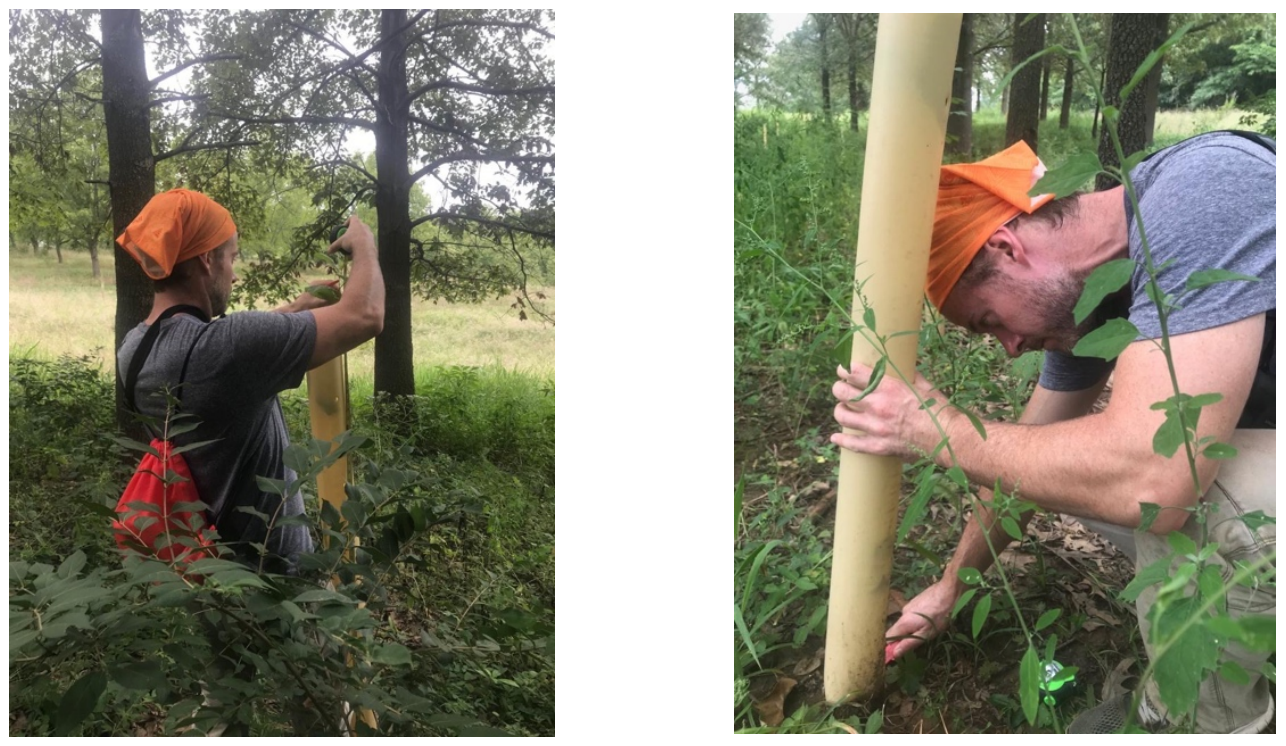

Fig. 4 Height and root collar diameter measurements were taken on all M. rubra seedlings.

To estimate dry matter yield, destructive sampling was used in late August of 2018. Seedlings were bottom pruned and fresh weight and the number of stems were recorded for the five most vital seedlings in each plot. Whole plant dry matter (DM) was recorded and leaf to stem $(\mathrm{L}: \mathrm{S})$ ratio was determined by separating leaves with petiole from the stems. Sub-samples of plant fractions (whole plant, leaf, and stem) were dried in an oven at $60{ }^{\circ} \mathrm{C}$ for $48 \mathrm{~h}$ for DM determination. Fresh yield was converted to DM yield with the following equations:

DM yield plot $^{-1}=$ weight of fresh material $\times$ DM\% DM yield ha ${ }^{-1}=\mathrm{DM}_{\text {yield }}$ plot $^{-1} \mathrm{x}$ number of plots ha ${ }^{-1}$ 


\section{Leaf Nutritive Value}

Nutritive value was assessed in late August of 2018. Ten leaves on each of the

five target shrubs were collected and combined for each treatment. Composite samples of M. rubra leaves were dried to weight constancy, milled to a homogenized powder, and analyzed using wet chemistry procedures for dry matter crude protein (CP, \%), acid detergent fiber (ADF, \%), and neutral detergent fiber (NDF, \%), total digestible nutrients (TDN), relative feed value (RFV), and mineral content at the Diary One Forage Lab in Ithaca, NY.

\section{Data Analysis}

To analyze differences in seedling survival, we used a logistic mixed effects analysis of variance (ANOVA) model that provided an odds ratio, or probability of death, for each treatment. To better understand the structure of errors due to treatment, replicate, and tree number, we ran three null models without testing for fixed effects of treatment and month and recorded the -2 Residual Log Pseudo-Likelihood and General Chi-Square / DF fit statistics available using the Glimmix procedure in SAS (SAS® 2013). The second model using the compound symmetry (CS) covariance matrix structure gave the smallest fit statistics, so we used the CS structure for errors.

Tree density effects on all response variables were analyzed with a linear mixed model analysis of variance (ANOVA) using the MIXED procedure in SAS (SAS ${ }^{\circledR}$ 2013). We considered the overstory tree density treatments as main plots and sampling dates as repeated measures (Steel and Torrie 1980). Treatment, sampling date, and their interactions were considered fixed effects while the replicate block, treatment nested 
under replicate block, and sampling date nested under treatment and replicate block were considered random effects. The advantage of using a mixed model approach to analyze these data is the inclusion of a random intercept for each plot that serves to account for the clustered nature of tree plantings (Piepho et al. 2003). Additionally, we examined height and diameter growth increment by calculating an absolute growth rate (AGR; cm month $^{-1}$ ) following Kikvidze and Armas (2010) by using the following equation: AGR = $\left(\mathrm{W}_{2}-\mathrm{W}_{1}\right) /\left(\mathrm{t}_{2}-\mathrm{t}_{1}\right)$, where $\mathrm{W}$ represents either height or root collar diameter at $\mathrm{t}_{1}$ at the beginning of the study and $t_{2}$ at the end of the study (in months). All increment parameters were subsequently transformed using the natural logarithm to be used for analysis.

All dependent variables were tested for normality and $\log _{10}$ transformed when necessary to meet the assumption of homoscedasticity. A simple variance component matrix was used to include the random plot effect and the residual maximum likelihood estimation was used to estimate covariance parameters. When significant effects were detected, pair-wise comparisons were performed using the Tukey-adjusted least squares method. Main effects and all interactions were considered statistically significant when P $=<0.05$.

\section{Results}

\section{Understory Light Environment}

All four treatments differed significantly with respect to understory light levels in the summer and winter $(\mathrm{P}=<0.0001)$. There was a significant difference found between seasons $(\mathrm{P}=0.0012)$, but no interaction was found between treatment and season. Mean 
Global Site Factor ranged from summer values of $21.86 \%$ in D to winter values of $93.21 \%$ in $\mathrm{O}$ (Table 4).

Survival

In May of 2017, one year after the planting, 92 out of 160 seedlings remained, amounting to an overall survival rate of 57.5\% (Table 5). In May of 2018, 131 out of 160 seedlings remained, with an overall survival rate of $81.88 \%$.

Table 4 Global Site Factor (GSF) values representing the sum of direct and diffuse radiation (excluding reflected radiation) entering through canopy openings as a proportion of the amount of radiation that would fall on the same point given no overhead obstructions over the course of a year. Estimates given for dense (D), semi-dense (S-D), semi-open $(\mathrm{S}-\mathrm{O})$, and open $(\mathrm{O})$ treatments.

\begin{tabular}{ccc}
\hline & Global Site Factor (\%) \\
\hline Treatment & $\underline{\text { Summer }}$ & $\underline{\text { Winter }}$ \\
D & $21.86 \pm 1.74$ & $27.41 \pm 1.56$ \\
S-D & $43.80 \pm 1.98$ & $49.99 \pm 0.68$ \\
S-O & $66.21 \pm 2.11$ & $76.47 \pm 1.42$ \\
O & $92.03 \pm 1.92$ & $97.44 \pm 1.62$ \\
& & $\underline{\text { P-value }}$ \\
Factor & $\underline{\text { F-value }}$ & $<0.0001$ \\
Treatment & 66.43 & 0.0012 \\
Season & 1.86 & 0.2766 \\
Interaction & & \\
\hline
\end{tabular}

Means and standard errors are reported. F-values and significance values for the linear mixed model analysis are given. 
Overstory tree density significantly affected seedling survival $(P=0.0442)$. The odds of seedlings surviving in D were significantly lower than those surviving in S-O and $\mathrm{O}(\mathrm{P}=0.0472$ and $\mathrm{P}=0.0130$, respectively $)$, but not for $\mathrm{S}-\mathrm{D}$. No significant differences in odds of mortality existed between S-D, S-O, and O for any of the measurement periods (Table 5). Sampling period also affected seedling survival $(\mathrm{P}=0.0132)$, but only for $\mathrm{O}$ between month 16 and months 26 and $28(\mathrm{P}=0.0039$ and $\mathrm{P}=0.0039$, respectively). There were no significant interaction effects.

Table 5 Percentage of $M$. rubra seedlings $(\mathrm{N}=20)$ surviving during each measurement period in dense (D), semi-dense (S-D), semi-open (S-O) and open (O) treatments. Replanting activities occurred at the dashed line.

\begin{tabular}{|c|c|c|c|c|c|}
\hline \multirow{2}{*}{$\begin{array}{c}\text { Age } \\
\text { (months) }\end{array}$} & \multirow[b]{2}{*}{$\mathrm{D}$} & \multicolumn{2}{|c|}{ Tree Density } & \multirow[b]{2}{*}{$\mathrm{O}$} & \multirow[b]{2}{*}{ Overall } \\
\hline & & S-D & $\mathrm{S}-\mathrm{O}$ & & \\
\hline 0 & $100^{\mathrm{aA}}$ & $100^{\text {aA }}$ & $100^{\mathrm{aA}}$ & $100^{\text {aA }}$ & 100 \\
\hline$--\frac{12}{16}--$ & $\frac{57.5}{70}{ }^{\mathrm{aB}}$ & $\frac{60}{77.5} \overline{\mathrm{ab}} \overline{\mathrm{ab}}$ & $-\frac{57.5}{87 .} \overline{5}^{\mathrm{aB}}$ & $-\frac{55}{95^{\mathrm{aB}}}-$ & $-\frac{57.5}{82.5}$ \\
\hline 24 & $70^{\mathrm{aC}}$ & $77.5^{a b C}$ & $87.5^{\mathrm{bC}}$ & $92.5^{\mathrm{bA}}$ & 81.88 \\
\hline 26 & $70^{\mathrm{aC}}$ & $77.5^{a b C}$ & $87.5^{\mathrm{bC}}$ & $90^{\mathrm{bC}}$ & 81.25 \\
\hline 28 & $70^{\mathrm{aC}}$ & $77.5^{\mathrm{abC}}$ & $87.5^{\mathrm{bC}}$ & $90 \mathrm{bC}$ & 81.25 \\
\hline
\end{tabular}

Numbers that share a letter are not statistically different from one another at $\alpha=.05$ (lower case indicates treatment differences; upper case indicates differences in measurement period).

Growth

Seedling growth was less vigorous than expected, with a mean seedling height of $83.77 \mathrm{~cm}$, mean diameter of $1.28 \mathrm{~mm}$, and mean crown width of $59.33 \mathrm{~cm}$ after 28 
months of growth. There was no overall treatment effect on seedling height $(\mathrm{P}=0.0637)$, although least squares mean estimates increased numerically under increasing canopy openness (Table 6). As expected, significant differences existed between sampling dates $(\mathrm{P}=0.0001)$, with the exception of growth between months 14 and $16(\mathrm{P}=0.3016)$ and months 26 and $28(\mathrm{P}=0.5940)$ (Table 6$)$. A statistically significant interaction was found between overstory treatment and sampling date $(\mathrm{P}=0.0005)$. Although the treatment groups never became significantly different at one sampling point, the strength of the treatment effect increased over time (Fig. 5).

The analysis of mean AGR for height similarly revealed no treatment differences, but showed differences for year and treatment*year. Height mean AGR was significantly greater in 2017 than it was for $2018(\mathrm{P}=0.0196)$. The treatment*year effect showed that mean AGR in treatment D was significantly less than mean AGR in S-D, S-O, and O in 2017 but not for $2018(\mathrm{P}=0.0129)$. Interestingly, in 2018, when all AGRs were lower, treatment D had an AGR of $22.43 \mathrm{~cm} \mathrm{yr}^{-1}$ compared with 19.70, 18.93, and $14.88 \mathrm{~cm} \mathrm{yr}^{-1}$ for O, S-O, and S-D, respectively (Fig. 6).

Generally, seedling diameter increased as tree density decreased (Table 6). Significant differences in diameter existed between all sampling dates $(\mathrm{P}=0.0001)$, with the exception of months 0 and $14(\mathrm{P}=0.1381), 0$ and $16(\mathrm{P}=0.0639), 14$ and $16(\mathrm{P}=$ $0.9924)$, and 16 and $26(\mathrm{P}=0.0536)$. A statistically significant interaction was found between overstory treatment and sampling date $(\mathrm{P}=0.0405)$. Similar to results presented for height, the strength of the treatment effect increased over time (Fig. 7). In fact, in the last measurement period, significant differences existed between $\mathrm{D}$ and $\mathrm{O}(\mathrm{P}=0.0028)$ and between S-D and $\mathrm{O}(\mathrm{P}=0.0016)$. 
The analysis of diameter AGR showed significant treatment $(\mathrm{P}=0.0255)$ and year effects $(\mathrm{P}=0.0102)$, but no interaction effect $(\mathrm{P}=0.2826)$. Post-hoc Tukey tests showed a significant difference between treatments $\mathrm{S}-\mathrm{D}$ and $\mathrm{O}(\mathrm{P}=0.0463)$, with $\mathrm{O}$ displaying significantly greater mean diameter AGR than S-D (Fig. 8). Diameter AGR was significantly less in 2017 than it was for $2018(\mathrm{P}=0.0102)$.

Crown width $(\mathrm{cm})$ was not affected by treatment $(\mathrm{P}=0.2289)$ but sampling dates differed significantly $(\mathrm{P}=0.0001)$. There was a statistically significant interaction between overstory treatment and sampling date $(\mathrm{P}=0.0003)$ (Fig. 9). The treatment effect varied for each sampling date, with some treatments affecting crown widths significantly during particular sampling dates and not during others (Table 6).

\section{Dry Matter Production}

Overstory tree density significantly affected $M$. rubra dry matter yield $(\mathrm{P}=$ 0.0008). Post-hoc tests showed that seedlings in D and S-D produced significantly less dry matter than those in $\mathrm{O}(\mathrm{P}=0.0352$ and $\mathrm{P}=0.0026$, respectively $)$ and $\mathrm{S}-\mathrm{O}(\mathrm{P}=0.0012$ and $\mathrm{P}=00019$, respectively) (Fig. 10). Seedlings in S-O produced the greatest amount of biomass with a total of $169.15 \mathrm{~kg} \mathrm{ha}^{-1}$, followed closely by $\mathrm{O}$ which produced $164.37 \mathrm{~kg}$ ha ${ }^{-1}$. Leaf weight differed significantly between treatments $(P=0.0023)$, increasing with overstory openness and differing significantly between all groups with the exception of S-O and O and D and S-D. Stem weight also differed significantly between treatments ( $\mathrm{P}$ $=0.0143) . \mathrm{S}-\mathrm{O}$ had the greatest mean stem weight $\left(77.76 \mathrm{~kg} \mathrm{ha}^{-1}\right)$, which differed significantly from $\mathrm{D}(\mathrm{P}=0.0259)$ and $\mathrm{S}-\mathrm{D}(0.0242)$, but not for $\mathrm{O}(\mathrm{P}=0.8840)$. There were no treatment effects on stem count $(\mathrm{P}=0.2878)$. Lastly, the leaf to stem ratio differed significantly between treatments $(P=0.0452)$, ranging from 0.8390 in $\mathrm{D}$ to 
1.1890 in S-O (Table 7). Post-hoc tests showed that the leaf to stem ratio in D was significantly lower than $\mathrm{S}-\mathrm{O}(\mathrm{P}=0.0084)$ and $\mathrm{O}(\mathrm{P}=0.031)$, but did not differ from $\mathrm{S}-\mathrm{D}$ $(P=0.2015)$.

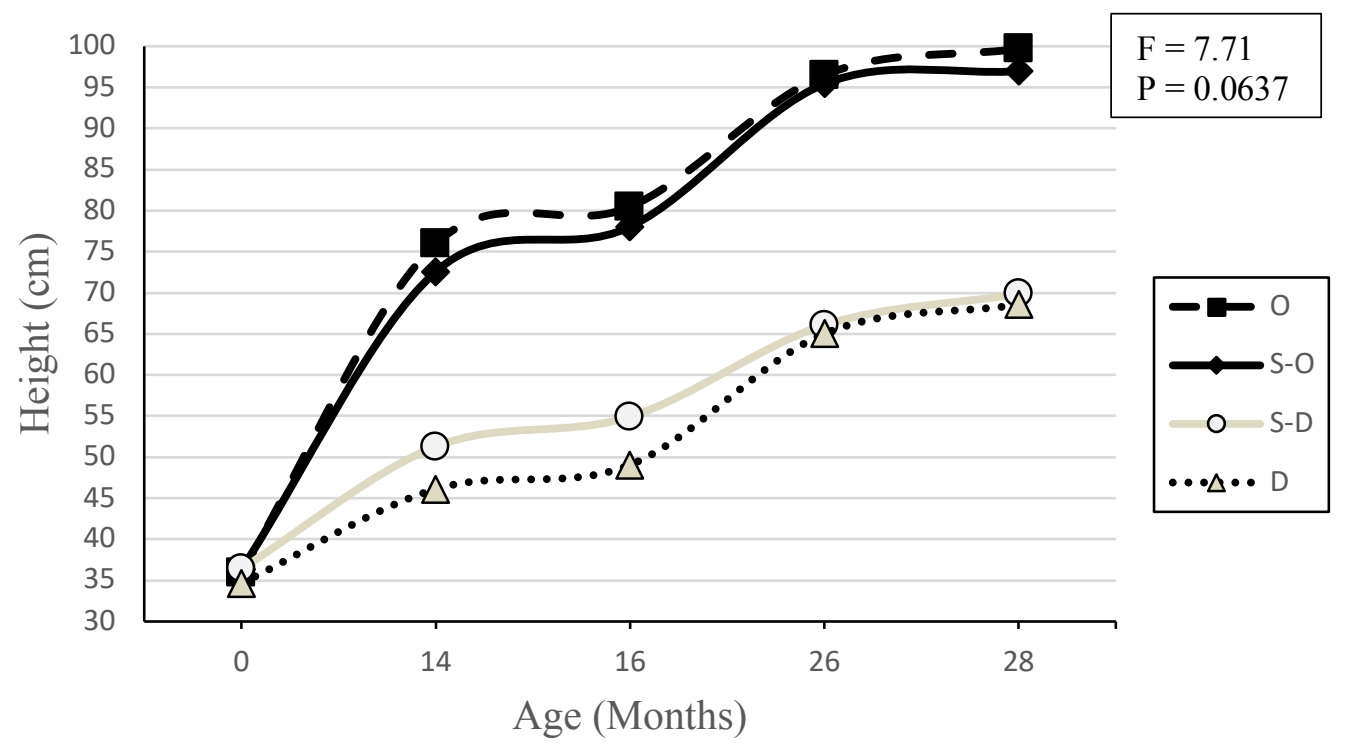

Fig. 5 Mean height $(\mathrm{cm})$ of the target trees growing under four different tree densities throughout the 28-month sampling period. 
Table 6 Least squares means estimates obtained for the growth parameters height (ht; $\mathrm{cm})$, root collar diameter (rcd; mm), and crown width (cw; cm) in M. rubra seedlings planted under four tree densities at HARC in New Franklin, MO.

\begin{tabular}{|c|c|c|c|c|c|c|c|c|c|c|c|c|}
\hline \multirow[b]{3}{*}{ Treatment } & \multicolumn{12}{|c|}{ Time Period (months after planting) } \\
\hline & \multicolumn{3}{|c|}{$0-14$} & \multicolumn{3}{|c|}{$14-16$} & \multicolumn{3}{|c|}{$16-26$} & \multicolumn{3}{|c|}{$26-28$} \\
\hline & $\mathrm{ht}$ & $\mathrm{rcd}$ & $\mathrm{cw}$ & ht & $\mathrm{rcd}$ & $\mathrm{cw}$ & ht & $\mathrm{rcd}$ & $\mathrm{cw}$ & ht & $\mathrm{rcd}$ & $\mathrm{cw}$ \\
\hline $\mathrm{D}$ & $46.12 \mathrm{aA}$ & $0.61 \mathrm{aA}$ & $42.37 \mathrm{aA}$ & $49.04 \mathrm{aA}$ & $0.67 \mathrm{aA}$ & $46.38 \mathrm{aA}$ & $65.03 \mathrm{aB}$ & $1.09 \mathrm{aB}$ & $52.11 \mathrm{aC}$ & $68.55 \mathrm{aB}$ & $1.19 \mathrm{aB}$ & $53.93 \mathrm{aD}$ \\
\hline S-D & 51.29abA & $0.68 \mathrm{abA}$ & $39.18 \mathrm{aA}$ & $54.92 \mathrm{aA}$ & $0.74 \mathrm{abA}$ & $48.95 \mathrm{aB}$ & $66.06 \mathrm{aB}$ & $1.09 \mathrm{aA}$ & $55.58 \mathrm{aC}$ & $69.86 \mathrm{aB}$ & 1.09abA & $55.58 \mathrm{aC}$ \\
\hline $\mathrm{S}-\mathrm{O}$ & 72.56abA & $0.96 \mathrm{abA}$ & $39.94 \mathrm{aA}$ & 78.03abA & 1.04abA & $49.17 \mathrm{aB}$ & $95.42 \mathrm{bB}$ & $1.67 \mathrm{abB}$ & $57.37 \mathrm{aC}$ & $96.97 \mathrm{bB}$ & $2.44 \mathrm{bC}$ & $62.48 \mathrm{bC}$ \\
\hline $\mathrm{O}$ & $75.95 \mathrm{bA}$ & $1.06 \mathrm{bA}$ & $43.36 \mathrm{aA}$ & $80.46 \mathrm{bA}$ & $1.18 \mathrm{bA}$ & $51.54 \mathrm{aB}$ & $96.51 \mathrm{bB}$ & $1.83 \mathrm{bB}$ & $55.44 \mathrm{aB}$ & $99.69 \mathrm{bB}$ & $3.17 \mathrm{abC}$ & $65.33 \mathrm{C}$ \\
\hline
\end{tabular}

Means sharing the same letter in a row or column are not significantly different from one another at $\mathrm{P}<0.05$. Lower case letters represent treatment differences (columns); upper case letters represent differences between sampling dates (rows). 


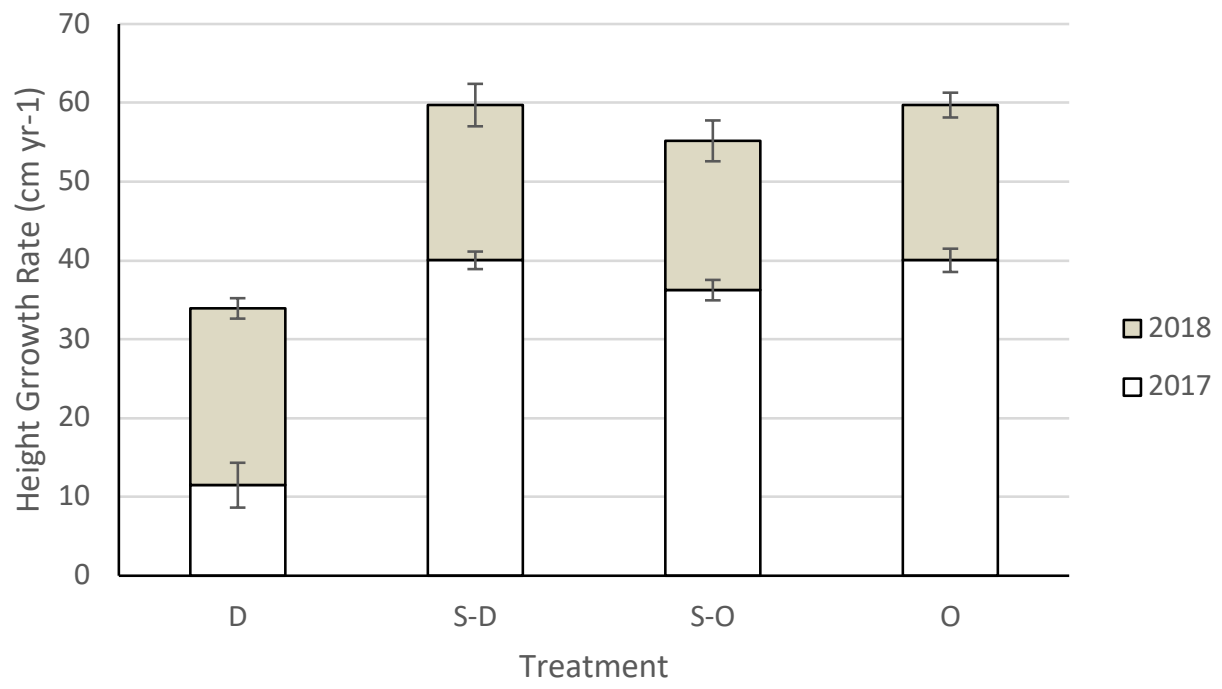

Fig. 6 Mean absolute growth rate for height $\left(\mathrm{cm} \mathrm{yr}^{-1}\right)$ in 2017 and 2018. Significant differences existed between treatment D and all other treatments for 2017 but not for 2018.

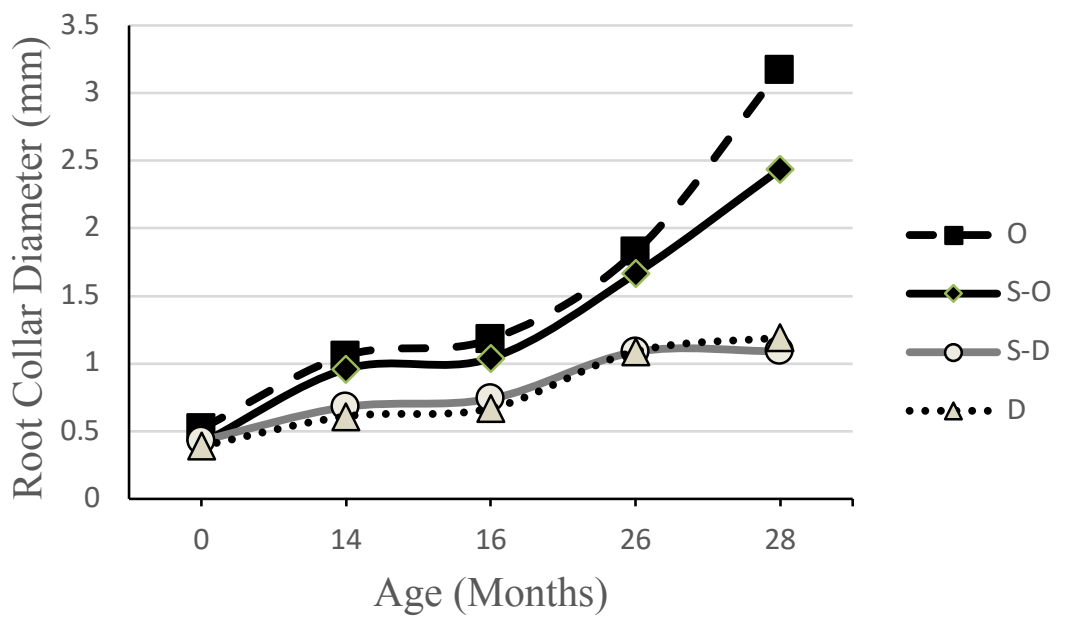

Fig. 7 Mean root collar diameter $(\mathrm{mm})$ of the target trees growing under four different tree densities throughout the 28-month sampling period. 


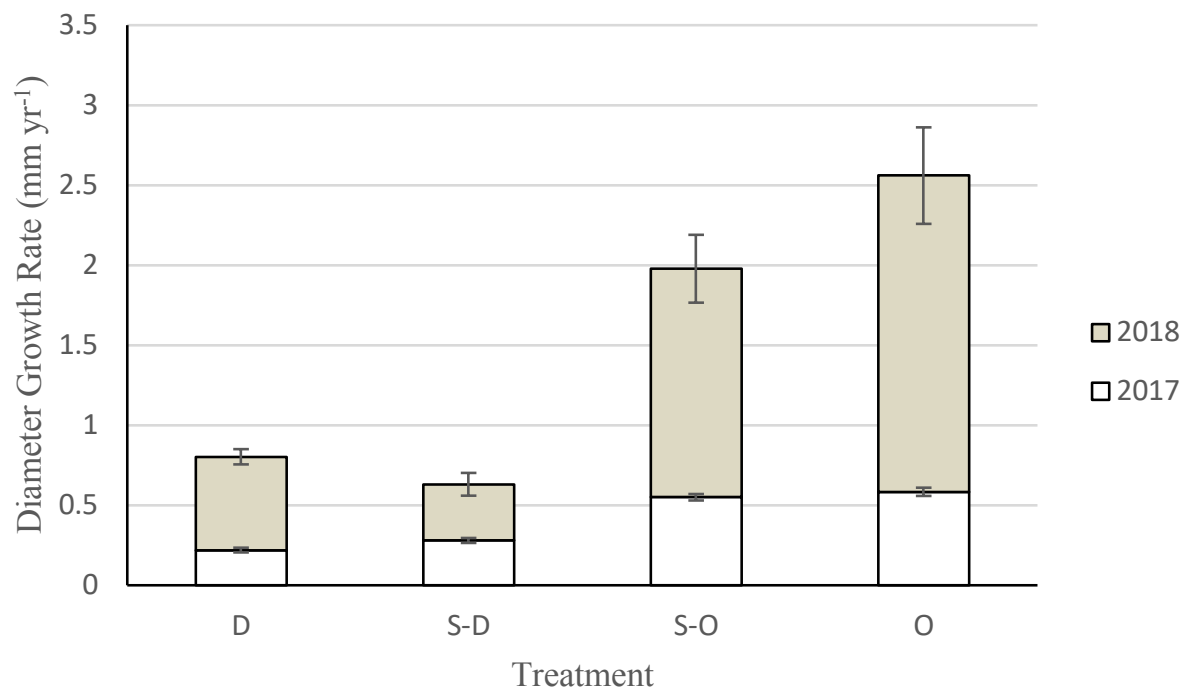

Fig. 8 Mean absolute growth rate for diameter (mm) in 2017 and 2018. A significant difference existed between treatments S-D and O.

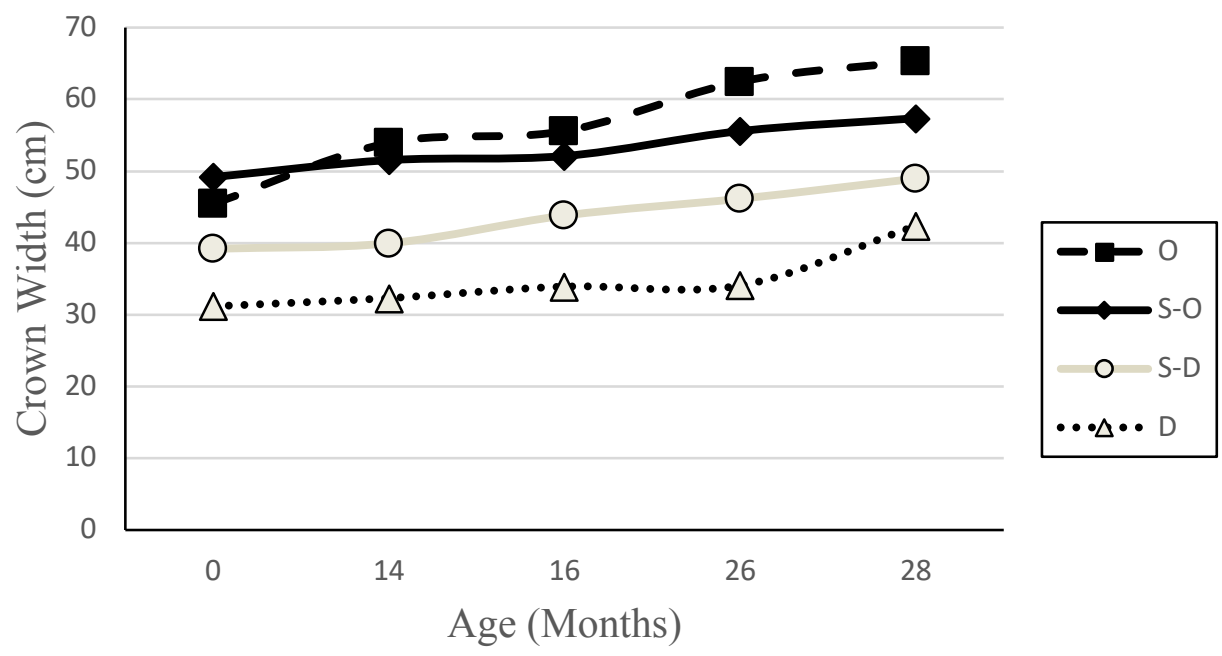

Fig. 9 Mean crown width $(\mathrm{cm})$ of the target trees growing under four different tree densities throughout the 28-month sampling period. 
Table 7 Least squares means estimates obtained for mean dry matter weight of individual plant (kg), number of stems, leaf weight $\left(\mathrm{kg} \mathrm{ha}^{-1}\right)$, stem weight $\left(\mathrm{kg} \mathrm{ha}^{-1}\right)$, leaf to stem ratio $(\mathrm{L}: \mathrm{S})$, and total dry matter yield $\left(\mathrm{kg} \mathrm{ha}^{-1}\right)$ for five target $M$. rubra shrubs planted in dense (D), semi-dense (S-D), semi-open (S-O) and open (O) treatments at HARC in New Franklin, MO.

\begin{tabular}{|c|c|c|c|c|c|c|}
\hline Treatment & $\begin{array}{c}\text { Number of } \\
\text { Stems }\end{array}$ & Leaf Weight $(\mathrm{g})$ & Stem Weight $(\mathrm{g})$ & $\mathrm{L}: \mathrm{S}$ & $\begin{array}{l}\text { DM (kg } \\
\left.\text { plant }^{-1}\right)\end{array}$ & $\mathrm{DM}\left(\mathrm{kg} \mathrm{ha}^{-1}\right)$ \\
\hline $\mathrm{D}$ & $5 \pm 0.6 \mathrm{a}$ & $46 \pm 2 \mathrm{a}$ & $54.9 \pm 6 \mathrm{a}$ & $0.84 \pm 0 \mathrm{a}$ & $101 \pm 12 \mathrm{a}$ & $112 \pm 10 \mathrm{a}$ \\
\hline S-D & $4 \pm 0.4 \mathrm{a}$ & $53.9 \pm 5 \mathrm{a}$ & $54.5 \pm 7 \mathrm{a}$ & $\begin{array}{c}1.00 \pm 0.1 \mathrm{a} \\
1.20 \pm 0.1\end{array}$ & $108 \pm 12 \mathrm{a}$ & $120 \pm 13 \mathrm{a}$ \\
\hline $\mathrm{S}-\mathrm{O}$ & $5 \pm 0.8 \mathrm{a}$ & $82.3 \pm 6 b$ & $69.9 \pm 7 b$ & $\begin{array}{c}\mathrm{b} \\
1.20 \pm 0.1\end{array}$ & $152 \pm 17 b$ & $169 \pm 16 b$ \\
\hline $\mathrm{O}$ & $5 \pm 0.6 \mathrm{a}$ & $79.9 \pm 6 b$ & $68 \pm 8 b$ & $\mathrm{~b}$ & $148 \pm 16 b$ & $164 \pm 12 b$ \\
\hline
\end{tabular}

Means sharing the same letter in a column are not significantly different from one another at $\mathrm{P}<0.05$. 
Specific Leaf Area

The specific leaf area of M. rubra differed significantly between treatments $(\mathrm{P}=$ 0.0062). Shrubs in the understory of D and S-D had the greatest specific leaf areas, with 114.85 and $77.29 \mathrm{~cm}^{2} \mathrm{~g}^{-1}$, respectively, compared with specific leaf areas of 49.86 and $33.25 \mathrm{~cm}^{2} \mathrm{~g}^{-1}$ in S-O and $\mathrm{O}$, respectively. Mean specific leaf area in D was significantly greater than that in $\mathrm{O}$ and $\mathrm{S}-\mathrm{O}(\mathrm{P}=0.0058$ and $\mathrm{P}=0.0113$, respectively $)$ while mean specific leaf area in $\mathrm{S}-\mathrm{D}$ was significantly greater than that in $\mathrm{O}(\mathrm{P}=0.0336)$ (Fig. 11).

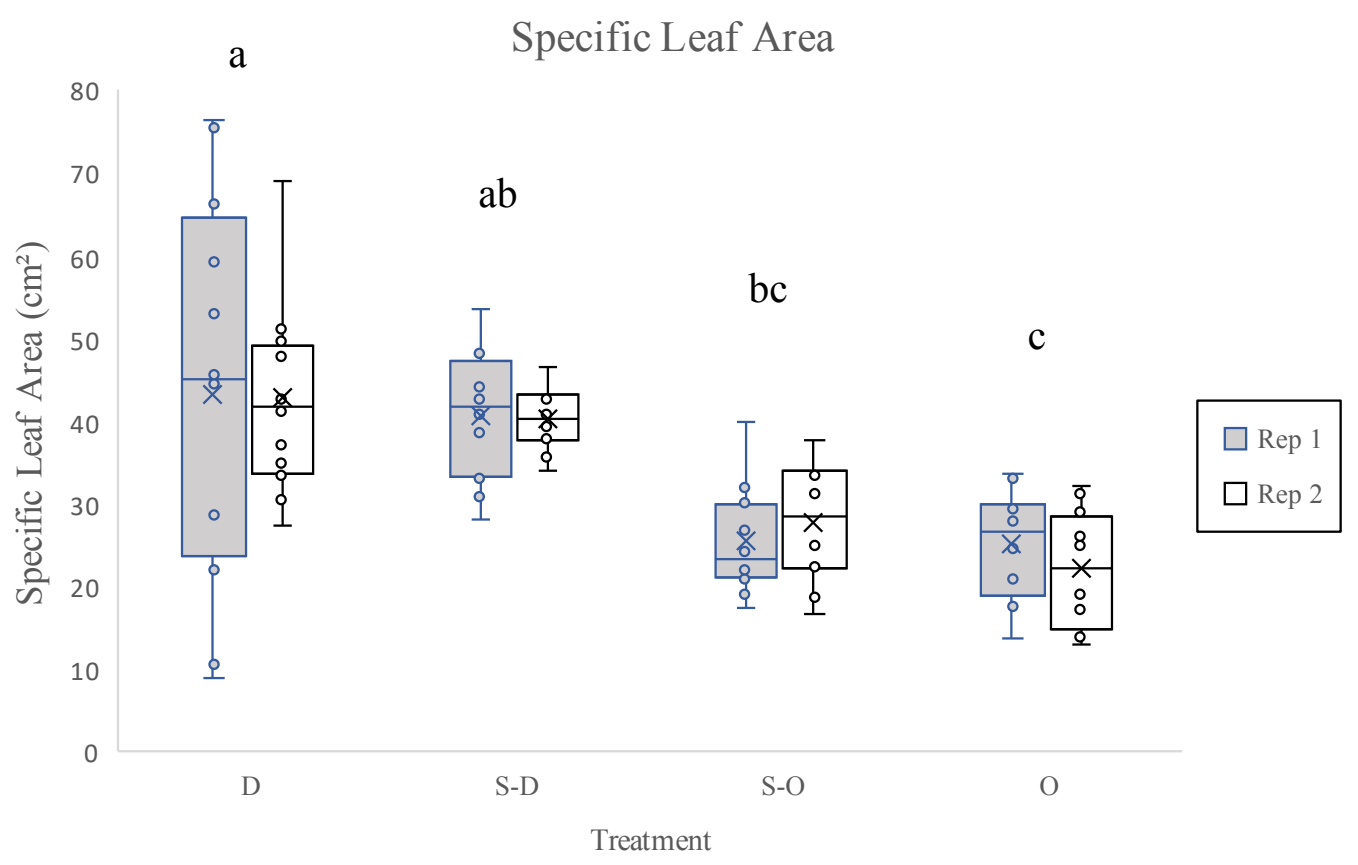

Fig. 10 Mean specific leaf area (SLA) values measured from 40 leaves per plot growing on M. rubra seedlings planted in dense (D), semi-dense (S-D), semi-open (S-O) and open (O) treatments at HARC in New Franklin, MO. 


\section{Nutritive Value}

There were significant differences between treatment groups in regards to several important nutritive value parameters (Table 8). M. rubra leaf crude protein (CP) content differed significantly between treatments $(\mathrm{P}=0.0075) . \mathrm{CP}$ content reached its highest value of $24.10 \%$ in S-D and its lowest value of $15.25 \%$ in S-O. Post-hoc Tukey tests revealed that significant differences in $\mathrm{CP}$ only existed between $\mathrm{D}$ and $\mathrm{S}-\mathrm{O}(\mathrm{P}=0.0184)$, $\mathrm{D}$ and $\mathrm{O}(\mathrm{P}=0.0223), \mathrm{S}-\mathrm{D}$ and $\mathrm{S}-\mathrm{O}(\mathrm{P}=0.0040)$, and $\mathrm{S}-\mathrm{D}$ and $\mathrm{O}(\mathrm{P}=0.0047)$. The fiber components of $M$. rubra leaves differed between treatments for ADF $(\mathrm{P}=0.0120)$, but not for NDF $(\mathrm{P}=0.1663)$. ADF increased directly proportionally to tree density, with a range of $12.35 \%$ to $17.7 \%$. Significant differences existed for ADF between D and S-O $(\mathrm{P}=0.0263), \mathrm{D}$ and $\mathrm{O}(\mathrm{P}=0.0116)$, and $\mathrm{S}-\mathrm{D}$ and $\mathrm{O}(\mathrm{P}=0.038)$. NDF followed a similar pattern as ADF, with values generally increasing with overstory tree density. However, ADF content of leaves from S-D was marginally greater than D.

Total digestible nutrients (TDN) and relative feed value (RFV) did not differ among treatments (TDN: $\mathrm{P}=0.2846 ; \mathrm{RFV}: \mathrm{P}=0.1170)$. Both measurements decreased numerically with increasing tree cover, but these differences were not statistically significant. Most major mineral concentrations did not differ significantly in M. rubra leaves between treatments, but an overall pattern of declining mineral concentration at lower tree densities emerged (Table 9). $\mathrm{K}, \mathrm{Mg}, \mathrm{Ca}, \mathrm{Fe}, \mathrm{Zn}, \mathrm{Cu}$, and $\mathrm{Mb}$ all showed numerical declines as tree density decreased. There was a significant treatment effect in leaf concentrations of $\mathrm{Mg}(\mathrm{P}=0.0372) . \mathrm{Mg}$ concentrations in $M$. rubra leaves growing under $\mathrm{D}$ were significantly greater than those in $\mathrm{O}(\mathrm{P}=0.0321)$. 
Table 8 Least squares mean estimates obtained for the major nutritive value parameters acid detergent fiber (ADF, \%), neutral detergent fiber (NDF, \%), crude protein (CP, \%), total digestible nutrients (TDN, \%), and relative feed value (RFV) in M. rubra leaves collected in dense (D), semi-dense (S-D), semi-open (S-O), and open (O) treatments at HARC in New Franklin, MO.

\begin{tabular}{cccccc}
\hline Treatment & ADF (\%) & NDF (\%) & CP (\%) & TDN (\%) & RFV \\
\hline D & $17.7 \pm 0.9 \mathrm{a}$ & $31.8 \pm 1.35 \mathrm{a}$ & $22.9 \pm 0.65 \mathrm{a}$ & $64.5 \pm 0.5 \mathrm{a}$ & $221 \pm 11.5 \mathrm{a}$ \\
$\mathrm{S}-\mathrm{N}$ & $15.9 \pm 0.05 \mathrm{ab}$ & $33.3 \pm 1.35 \mathrm{a}$ & $24.1 \pm 1.4 \mathrm{a}$ & $64.5 \pm 0.5 \mathrm{a}$ & $215 \pm 8.5 \mathrm{a}$ \\
$\mathrm{S}-\mathrm{O}$ & $13.7 \pm 0.1 \mathrm{bc}$ & $29.0 \pm 2.95 \mathrm{a}$ & $15.3 \pm 0.35 \mathrm{~b}$ & $65.0 \pm 1.0 \mathrm{a}$ & $254 \pm 26 \mathrm{a}$ \\
& & & & \\
$\mathrm{O}$ & $12.4 \pm 0.35 \mathrm{c}$ & $25.3 \pm 1.3 \mathrm{a}$ & $15.8 \pm 1.15 \mathrm{~b}$ & $66.5 \pm 0.5 \mathrm{a}$ & $292 \pm 14 \mathrm{a}$ \\
\hline
\end{tabular}

Means \pm SE sharing the same letter in a column are not significantly different from one another at $\mathrm{P}<0.05$ 
Table 9 Least squares mean estimates obtained for the minerals Potassium (K, \%), Magnesium (Mg, \%), Phosphorus (P, \%), Calcium (Ca, \%), Sodium (Na, \%), Iron (Fe, ppm), Zinc (Zn, ppm), Copper (Cu, ppm), Manganese (Mn, ppm), and Molybdenum (Mb, ppm) in M. rubra leaves collected in dense (D), semi-dense (S-D), semi-open (S-O) and open (O) treatments at HARC in New Franklin, MO.

\begin{tabular}{|c|c|c|c|c|c|c|c|c|c|c|}
\hline Treatment & $\mathrm{K}(\%)$ & $\operatorname{Mg}(\%)$ & $\mathrm{P}(\%)$ & $\mathrm{Ca}(\%)$ & $\mathrm{Na}(\%)$ & $\begin{array}{c}\mathrm{Fe} \\
(\mathrm{ppm})\end{array}$ & $\begin{array}{c}\mathrm{Zn} \\
(\mathrm{ppm})\end{array}$ & $\begin{array}{c}\mathrm{Cu} \\
(\mathrm{ppm})\end{array}$ & $\begin{array}{c}\mathrm{Mn} \\
(\mathrm{ppm})\end{array}$ & $\begin{array}{c}\mathrm{Mb} \\
(\mathrm{ppm})\end{array}$ \\
\hline $\mathrm{D}$ & $\begin{array}{l}2.665 \pm \\
0.145^{\mathrm{a}}\end{array}$ & $\begin{array}{l}0.45{ }^{ \pm} \\
0.02^{a}\end{array}$ & $\begin{array}{l}0.422^{ \pm} \\
0.07^{\text {a }}\end{array}$ & $\begin{array}{c}2.62 \pm \\
0.6^{\mathrm{a}}\end{array}$ & $\begin{array}{l}0.0175 \pm \\
0.0005^{\text {a }}\end{array}$ & $\begin{array}{c}251^{ \pm} \\
32^{a}\end{array}$ & $\begin{array}{l}52 \pm \\
1.0^{\mathrm{a}}\end{array}$ & $\begin{array}{l}10 \pm \\
2.0^{\mathrm{a}}\end{array}$ & $\begin{array}{l}141 \pm \\
33.0^{\text {a }}\end{array}$ & $\begin{array}{l}0.95 \pm \\
0.05^{\text {a }}\end{array}$ \\
\hline S-D & $\begin{array}{l}2.5 \pm \\
0.44^{\mathrm{a}}\end{array}$ & $\begin{array}{l}0.325 \pm \\
0.045^{\mathrm{ab}}\end{array}$ & $\begin{array}{l}0.415 \pm \\
0.005^{\mathrm{a}}\end{array}$ & $\begin{array}{c}2.315 \\
\pm \\
0.295^{\mathrm{a}}\end{array}$ & $\begin{array}{l}0.01 \pm \\
0.004^{\mathrm{a}}\end{array}$ & $\begin{array}{c}200 \pm \\
76^{\mathrm{a}}\end{array}$ & $\begin{array}{c}37.5^{ \pm} \\
9.5^{\mathrm{a}}\end{array}$ & $\begin{array}{l}7 \pm \\
1.0^{\mathrm{a}}\end{array}$ & $\begin{array}{l}88.5 \pm \\
24.5^{\text {a }}\end{array}$ & $\begin{array}{l}0.95 \pm \\
0.05^{a}\end{array}$ \\
\hline $\mathrm{S}-\mathrm{O}$ & $\begin{array}{l}2.205 \pm \\
0.165^{\mathrm{a}}\end{array}$ & $\begin{array}{l}0.365 \pm \\
0.005^{\mathrm{ab}}\end{array}$ & $\begin{array}{l}0.5 \pm \\
0.0^{\mathrm{a}}\end{array}$ & $\begin{array}{c}2.375 \\
\pm \\
0.055^{\mathrm{a}}\end{array}$ & $\begin{array}{l}0.0044^{ \pm} \\
0.002^{\mathrm{a}}\end{array}$ & $\begin{array}{c}187 \pm \\
16^{\mathrm{a}}\end{array}$ & $\begin{array}{c}36.5^{ \pm} \\
5.5^{\mathrm{a}}\end{array}$ & $\begin{array}{l}7 \pm \\
1.0^{\mathrm{a}}\end{array}$ & $\begin{array}{c}108.5 \pm \\
3.5^{\mathrm{a}}\end{array}$ & $\begin{array}{l}0.6 \pm \\
0.2^{\mathrm{a}}\end{array}$ \\
\hline $\mathrm{O}$ & $\begin{array}{l}2.025 \pm \\
0.035^{\mathrm{a}}\end{array}$ & $\begin{array}{l}0.275^{ \pm} \\
0.005^{b}\end{array}$ & $\begin{array}{l}0.4 \pm \\
0.0^{\mathrm{a}}\end{array}$ & $\begin{array}{l}2.13^{ \pm} \\
0.15^{\mathrm{a}}\end{array}$ & $\begin{array}{l}0.006 \pm \\
0.002^{\mathrm{a}}\end{array}$ & $\begin{array}{c}120^{ \pm} \\
3.0^{\mathrm{a}}\end{array}$ & $\begin{array}{c}27.5^{ \pm} \\
0.5^{\mathrm{a}}\end{array}$ & $\begin{array}{c}6 \pm \\
0.0^{\mathrm{a}}\end{array}$ & $\begin{array}{c}65.5^{ \pm} \\
2.5^{\mathrm{a}}\end{array}$ & $\begin{array}{l}0.35^{ \pm} \\
0.15^{\mathrm{a}}\end{array}$ \\
\hline
\end{tabular}

Means \pm SE sharing the same letter in a column are not significantly different from one another at $\mathrm{P}<0.05$ 


\section{Discussion}

Survival

Our hypothesis predicting highest survival in O was only partially supported. We reported an overall seedling survival rate of $57.55 \%$ in 2017 and $81.88 \%$ in 2018 , with lowest survival in D, where overstory tree density was highest. In 2018, the majority of seedling mortality occurred in D within the first four months after replanting during a period coinciding with an extreme drought (D3) causing very poor pasture conditions (Dailey 2018). However, there were no differences in survival between treatments S-D, S-O, and O, suggesting that M. rubra seedlings are capable of equal survival under moderate shade of at least up to $43.80 \%$ GSF on this site.

Shade tolerance is well known for this species, as it grows naturally in shaded understory environments throughout eastern North America. In fact, some authors have even reported that $M$. rubra seedling emergence is negatively associated with irradiance and positively associated with groundcover (Burton and Bazzaz 1991). Shade tolerance, along with a productive lifespan of up to 125 years is why this species is recommended as one of many multifunctional perennial cropping (MPC) species (Lovell and Wilson 2017). Surprisingly, Burgess and Husband (2006) showed that M. rubra seedlings growing in Ontario, Canada had consistently lower survival in both shaded and unshaded habitats when compared with $M$. alba and M. alba $x$ rubra hybrids. Only $18.4 \%$ of $M$. rubra survived in their study, compared to $81.3 \%$ of $M$. alba $x$ rubra hybrids and $91.2 \%$ of M. alba. The observed inferior fitness of $M$. rubra could be due to differences in species distributions, as Ontario is at the northern limit of its geographical range while that of M. alba extends further north. However, improved fitness of white-red crosses 
could be due to hybrid vigor, which could jeopardize future survival of wild populations of M. rubra (Burgess and Husband 2006).

Will et al. (2013) examined seedling response to drought on a forest-grassland ecotone in Oklahoma and found that field-planted M. rubra seedlings died only five days after watering was discontinued. This was faster than all nine other species tested, suggesting that $M$. rubra is relatively susceptible to drought-induced mortality. There is some indication that M. alba is slightly more drought tolerant than M. rubra (California Rare Fruit Growers 1997). Studying the growth and survival of M. alba in China, Huang et al. (2013) showed that seedlings that were hardened to drought-like conditions performed significantly better in the field than those that were not. They concluded that M. alba trees showed strong resistance to drought that could be improved with droughthardening. Further study is needed to compare the drought tolerance and survival of these two species to help determine how climate change may affect their respective populations and appropriateness of use in silvopastoral systems in the future.

\section{Growth}

Growth was limited across all four treatments when compared with reports of heights between 1.5 and $1.75 \mathrm{~m}$ within six months (Sharma and Zote 2010). This could be due to either this site's $\mathrm{pH}$ of 5.01, which is well outside the optimal range of $6.5-6.8$ reported for this species (Sharma and Zote 2010), or to limited precipitation in both years of the study (Fig. 2). Our hypothesis predicting M. rubra growth to be significantly enhanced under increasing canopy openness was not supported for height and crown width but was supported for diameter. Height was not significantly affected by treatment, 
however there were numerical increases in height as canopy openness increased. Height and diameter responses were similar in treatments $\mathrm{S}-\mathrm{O}$ and $\mathrm{O}$ and similar in S-D and D. Crown width followed a similar trend, increasing numerically with canopy openness. Further study is needed to observe how these parameters change through time, as the treatment effect was strongest for both variables at the final measurement period.

By month 28 , diameter in $\mathrm{O}$ had increased to a point at which it was significantly different from that of the diameter of seedlings in D and S-D. These trends indicate that M. rubra grows most rapidly in open environments, a finding consistent with other reports (McClendon and McMillen 1982). Reporting on the growth and productivity of M. alba, Fukui (2000) claimed that the growth of one-year-old mulberry in the field is less uniform and inferior to that of mulberry grown for more than two years. Our finding that the seedlings put a disproportionate amount of energy into height increment the first year and diameter increment the second year supports this claim. Fukui (2000) suggested that these inconsistencies may be due to limitations of the root system during early growth. Continual study of growth parameters into the future will help elucidate how this species is affected by changes in canopy cover.

\section{Dry Matter Yield}

M. rubra seedlings produced significantly more DM in S-O and O than they did in S-D and D, partially supporting our hypothesis. Rather than demonstrating a step-wise positive response to natural light availability like we expected, DM production displayed a nearly asymptotic reaction, leveling off and even decreasing slightly moving from 
treatment $\mathrm{S}-\mathrm{O}$ to $\mathrm{O}$. This indicates that $M$. rubra seedlings on this site may be reaching a light saturation point somewhere between 66.21 and $92.03 \%$ GSF.

Leaf production was also greatest in $\mathrm{S}-\mathrm{O}$, corresponding with the highest leaf to stem ratio. Seedlings generally produced fewer stems as canopy openness increased, diverting more photosynthetic energy for the production of leaves. Leaves contain more protein and less fiber than stems, thus, an increased leaf to stem ratio has a positive effect on the quality of the forage (Lin et al. 2001). In a study conducted at HARC, Lin and colleagues (2001) showed that the leaf to stem ratio of alfalfa (Medicago sativa L.) was reduced by 20 and $30 \%$ in 50 and $80 \%$ shade, respectively. This is similar to our finding that leaf to stem ratio in $M$. rubra seedlings was reduced by 19 and $41.7 \%$ in $56.2 \%$ and 78.14\% shade, respectively. Conversely, Annighöfer (2018) showed that woody fractions of shade tolerant beech seedlings increased in response to greater light availability. Morphological adaptation to altered light availability in terms of leaf to stem ratio appears to depend on many factors, as other authors have reported that shade has little to no effect on the leaf to stem ratio of forage plants (Samarakoon 1990; Kephart and Buxton 1993)

Our data confirming greater specific leaf area (SLA) for shaded plants was not surprising, as this morphological adaptation to low irradiance levels is commonly reported in the literature (Loach 1970; Kephart and Buxton 1993). Plants exposed to reduced light often, but not always, compensate for reduced photosynthesis by producing leaves that are larger in area than related sun leaves (Hanson 1917). The large area of these leaves is correlated with reduced specific leaf dry weight, leaf thickness, and density (McClendon and McMillen 1982; Allard et al. 1991). The M. rubra seedlings in 
treatments D and S-D produced fewer, larger, presumably thinner leaves with reduced density than those in $\mathrm{S}-\mathrm{O}$ and $\mathrm{O}$. This likely contributed to overall lower DM production in D and S-D.

In terms of usable forage for livestock, leaf DM productivity is paramount. A literature review of DM productivity resulted in data reported for M. alba only, much of which dwarfed numbers reported here. Direct comparisons should not be made between studies due to many differing variables, including cultivar, latitude, climate, site fertility, fertilizer application, harvesting techniques, and plant density. However, we provide several examples of M. alba DM yield for reference. Sanchez (2000) claimed that white mulberry produces more DM than most traditional forages, with production of up to 40 tons $\mathrm{ha}^{-1} \mathrm{yr}^{-1}$ in intensively managed operations in the tropics. When planted with subterranean clover (Trifolium subterraneum) in a silvopasture in central Italy, M. alba produced between 4.2 and 5.3 tons DM ha-1 (Talamuci and Pardini 1999). Armand and Meuret (1993) demonstrated that the Japanese cultivar Kokuso 21 produced up to 2.2 tons ha ${ }^{-1}$ on good sites in France, but in poorer sites production was much lower at $444 \mathrm{~kg}$ $\mathrm{ha}^{-1}$.

There are many important differences in our study compared with those reported above, but several should be noted here. The first is that we report on DM yield produced from the initial pruning event. Once a shrub is bottom pruned, it will begin to sprout vigorously, producing greater quantities of total DM whereupon the tree can be shoot harvested, typically 12 weeks later (Sharma and Zote 2010). Although no direct evidence was found in the literature, there is some speculation that M. rubra does not pollard well, and this may be reduced even more in the shade. Due to time limitations, we were unable 
to determine whether or not this is true. The second difference to note is that DM yield estimates in the literature are reported for a variety of planting densities. It is well known that as plant spacing is reduced, yield plant ${ }^{-1}$ decreases owing to competition, but total forage yield ha ${ }^{-1}$ increases, as does the leaf to stem ratio (Gong et al. 1995). Periodic pollarding along with increasing the planting density could be two effective means of increasing overall DM production.

When M. rubra seedling DM production was compared with DM yield of sungrown non-pollarded M. alba, M. rubra produced more. After 32 months of growth, Fukui (2000) reported a stem and leaf DM mean of $63.4 \mathrm{~g}\left(70.44 \mathrm{~kg} \mathrm{ha}^{-1}\right)$ and $55.4 \mathrm{~g}$ (61.55 $\mathrm{kg} \mathrm{ha}^{-1}$ ) for 1995 and 1996, respectively. S-O and O grown M. rubra seedlings produced more than double that (169.15 and $\left.164.37 \mathrm{~kg} \mathrm{ha}^{-1}\right)$. Certainly, environmental and site differences prevent direct comparisons, but the example is used to demonstrate that when managed in a similar way, $M$. alba may not always be more productive than $M$. rubra.

Nutritive Value

Our hypothesis predicting leaf nutritive value to increase as understory light levels decreased was not supported. Treatments D and S-D had the highest CP content but they also had the highest ADF, resulting in negligible treatment differences in TDN and RFV. It is possible that elevated ADF levels in D and S-D were due to an increase in lignification caused by the reduction of soluble sugars and starches in the leaves. Many authors have made similar postulations, claiming that exposure to shade causes an increase in cell well content and a reduction in forage digestibility (Samarakoon 1990; 
Lin et al. 2001). The higher CP content of shade-grown leaves seen in this study may be due to canopy-induced microclimatic differences, such as increased soil moisture and moderate soil temperatures that can speed up the rate of $\mathrm{N}$ mineralization and turnover (Wilson 1996). Other authors have speculated that increased CP in shaded plants is due to the reduction in cell size attributed to leaf etiolation. These smaller cells contain similar concentrations of $\mathrm{N}$, resulting in a concentrating effect within each cell (Kephart and Buxton 1993).

Leaf mineral content was relatively high, with denser overstory treatments generally containing leaves with greater mineral content. Leaf phosphorus levels ranged from $0.35 \%$ to $0.50 \%$, with no significant change due to treatment. These numbers are greater than P concentrations reported for white mulberry in a review by Sanchez (2000), where concentrations of $0.14-0.24 \%$ were reported. Calcium concentrations were similar to those reported in the literature for M. alba $(1.8-2.4 \%)$. Espinoza et al. (1999) reported similar values for potassium in leaves $(1.9-2.87 \%)$, but higher values for magnesium $(.47-0.63 \%)$.

Overall, the nutritive value of M. rubra seedlings assessed during the summer forage slump surpassed the quality of many common pasture forages. Mean TDN for all four treatments was $65.13 \%$, comparable to that of leafy, immature legumes. Mean RFV for all four treatments was 245.25 , a number that is exceedingly high and indicative of high dry matter digestibility. Mean CP content for all four treatments was $19.48 \%$. This is comparable to CP levels recorded for alfalfa (M. sativa L.) and white clover (Trifolium repens $\mathrm{L}$.) in the spring during the vegetative stage on the same site (Lin et al. 2001). We reported an overall mean ADF and NDF of 14.9 and $29.81 \%$, respectively, even lower 
than the 26.67 and $33 \%$ reported for white clover in the same study (Lin et al. 2001). A study comparing the nutritive value of several woody species in northern Greece showed that M. alba had significantly less fiber (ADF 18.3\%; NDF 31.3\%) and significantly higher digestibility (IVOMD 75.6\%) than the other species tested (Ainalis et al. 2006). Kandylis et al. (2009) partially replaced alfalfa (M. sativa) hay and concentrates with mulberry leaves and found no significant differences in $\mathrm{DM}, \mathrm{CP}$, or crude fiber digestibility of the entire diet when fed to sheep.

Any presentation of woody forage nutritive value should mention the presence of anti-nutritional compounds that have the ability to severely restrict nutrient utilization (Papanastasis et al. 2008). Secondary compounds such as condensed tannins, alkaloids, saponins, and oxalates are known to occur in many woody perennials and can have detrimental effects to the animal if consumed in high quantities. However, diets containing herbaceous forage with a high level of digestible $\mathrm{CP}$ have been shown to counteract the negative effects of tannins (Yiakoulaki 1995). Further, tannins in low to moderate concentrations (20-40 $\mathrm{g} \mathrm{kg}^{-1} \mathrm{DM}$ ) can induce beneficial effects, which are associated with suppression of bloat in ruminants (Jones et al. 1973) No anti-nutritional factors or toxic compounds have been identified in M. alba (Sanchez 1999). Makkar (1989) identified mulberry as a "low tannin" fodder tree, with feeding experiments in India showing that up to $6 \mathrm{~kg}$ of leaves per day can be fed to cattle without adversely affecting the health of the animals or the yield and butter content of milk. 


\section{Conclusion}

M. rubra seedlings responded positively to increased light availability in terms of survival, growth, and productivity, but were not affected in terms of leaf nutritive value. Overall seedling survival was relatively high despite extreme drought conditions in 2018, and significant seedling mortality did not occur until below $43.8 \%$ GSF on this site. Seedlings expressed morphological plasticity with increased diameter growth, decreased specific leaf area, and increased DM yield as canopy openness increased. Seedlings appeared to reach a light saturation point somewhere between 66.21 and $92.03 \%$ GSF in terms of DM yield, obtaining highest leafiness at $66.21 \%$ GSF. Nutritive value did not differ significantly above $66.21 \%$ GSF in terms of CP and fiber fractions and did not differ significantly for any of the treatments in respect to digestibility (TDN and RFV). Our results indicate that $M$. rubra seedling survival, growth, productivity, and nutritive value can be optimized on this site at $66.21 \%$ GSF, an irradiance level that corresponds to an overstory planting density of $9 \times 9 \mathrm{~m}$.

\section{Management Recommendations}

Producers should pay careful attention to soil conditions and topographic landform when selecting perennial species for use in silvopastoral systems. M. rubra thrives in valleys, floodplains, and on mesic hillsides, with best growth reported for welldrained moist coves and along streams (Martin et al. 1961). Geophysical site conditions are likely to be of supreme importance to biological interactions between plants. Thus, plant selection should depend on the appropriateness of the site. 
It is highly recommended that future M. rubra management efforts are geared toward dual-purpose production of fodder and fruits to increase food supply and diversify on-farm resources. M. rubra has a dioecious reproductive strategy that would allow producers to create silvopastures with separate fodder and berry production. Male plants can be coppiced and browsed up to twice a year while female plants can be allowed to grow taller into fruit producing shrubs (Shepard 2013). However, shrubs are not good sources of energy after fruit development, so it is important to keep fodder shrubs pollarded, preferably above browse level where deer herbivory is prevalent.

\section{Study Limitations and Future Directions}

There were several limitations of this study which should not go unmentioned. Seedling growth is influenced by many different factors, including - but not limited to nutrient, space, and water availability; thus, the seedling responses reported here cannot be attributed solely to differences in light availability. We acknowledge that differences in overstory density will also result in variable microclimatic conditions, creating unforeseen stressors to plants growing in the understory. Additional study on seedling moisture stress, soil volumetric water content, and variable seedling planting distances could help elucidate which of these competitive forces is most responsible for differences in seedling response.

DM production estimates reported here should be interpreted with caution. Our measurements of DM production were assessed in an environment void of regular fertilizer application and nitrogen-fixing legumes. Despite thriving well with minimum fertilization (Sharma and Zote 2010), mulberry is a non-legume and planting this species 
in combinations with nitrogen-fixing forages can improve overall yield (Saddul et al. 2004). Moreover, DM yield was assessed at one point in time from the initial bottom pruning event. Both DM yield and nutritive value are known to vary widely throughout various stages of plant maturity and different harvesting cycles can dramatically affect both variables (Saddul et al. 2004; Kabi and Bareeba 2008).

Although we collected data during the most critical time of year, our results are limited in scope. Further research is needed to evaluate seedling response to defoliation and harvesting frequency under varying shade levels. It may be that white mulberry ( $M$. $a l b a)$ is a more appropriate choice for forage production under drought scenarios. Research is needed comparing productivity and growth responses of both species to understory light availability. Furthermore, future research should investigate livestock behavior in multi-strata systems to identify if and under what conditions livestock will consume M. rubra (Vandermeulen et al. 2018b) and what this means in terms of animal production during critical forage shortages. 


\section{Chapter 5}

\section{Conclusion}

Results reported in the preceding chapters have indicated that trees have both competitive and facilitative effects on forage production in silvopastoral systems, yet facilitation may be more prevalent during droughts.

In chapter two, we showed that grasses growing under increasing canopy cover demonstrated higher nutritive value and decreased production, with the exception of the cultivar Massai under moderate tree densities in February, which produced significantly more dry matter than dense and open treatments. This observed extension of the growing season under moderate tree densities could result in reduced animal weight loss between the months of January and April for this region.

In chapter three, we showed that there were no additional constraints to water availability and tree and grass growth when intercropped with fertilizer shrubs in the first two years after silvopasture establishment. Conversely, the planting, coppicing, and mulching of $T$. diversifolia and L. leucocephala increased several important soil fertility parameters, including plant available $\mathrm{N}$ and $\mathrm{P}$. Additionally, the intercropping of the Nfixing L. leucocephala marginally increased annual grass dry matter production. However, grass productivity was decreased in the presence of $T$. diversifolia, suggesting there are competitive forces at work that we could not discern in this study. During the dry season, cumulative forage production in plots with shrubs provided on average $9.66 \%$ more forage than plots without shrubs, diversifying and supplementing forage reserves.

In chapter four, we presented results showing that $M$. rubra seedling survival, growth, productivity, and nutritive value on this site appeared to reach a light saturation 
point between 66.21 and $92.03 \%$ GSF in terms of DM yield, obtaining highest leafiness at $66.21 \%$ GSF. This value corresponds to an overstory planting density of $9 \times 9 \mathrm{~m}(\sim 500$ trees $\mathrm{ha}^{-1}$ ). The nutritive value of $M$. rubra seedlings assessed during the summer forage slump surpassed the quality of many common pasture forages and could serve as a highly nutritional supplemental forage to livestock in multi-strata silvopastures during drought conditions. However, more research is needed to determine how M. rubra responds to repeated coppicing events, particularly during severe droughts.

The overall results of this research demonstrate that food security can be enhanced with the appropriate use and management of silvopastoral systems, but may not be ensured used in complete isolation of traditional rotational stocking of open pastures. We recommend the use of integrated systems that utilize silvopasture during critical periods of the year, such as January through April in Panama, and July and August in Missouri. During these times, moderate shade may provide a temporary boost in grass production as well as supplemental forage in the form of fruit from overstory trees and foliage from browsable fertilizer shrubs. Silvopasture should be used as a tool to diversify and increase forage production during these critical periods of the year, ensuring adequate animal nutrition and health throughout the year. 


\section{References}

Addlestone B, Mueller J, Luginbuhl J-M (1999) The establishment and early growth of three leguminous tree species for use in silvopastoral systems in the southeastern USA. Agrofor Syst 44:253-265. doi: 10.1023/A

Aganga A, Tshwenyane S (2003) Feeding Values and Anti-Nutritive Factors of Forage Tree Legumes. Pakistan J Nutr 2:170-177

Ainalis AB, Tsiouvaras CN, Nastis AS (2006) Effect of summer grazing on forage quality of woody and herbaceous species in a silvopastoral system in northern Greece. J Arid Environ 67:90-99. doi: 10.1016/j.jaridenv.2006.01.017

Ajayi OC, Place F, Akinnifesi FK, Sileshi GW (2011) Agricultural success from Africa: the case of fertilizer tree systems in southern Africa (Malawi, Tanzania, Mozambique, Zambia and Zimbabwe). Int J Agric Sustain 9:129-136. doi: $10.3763 /$ ijas.2010.0554

Alexandratos N (1995) World Agriculture Towards 2010. Rome, Italy

Allard G, Nelson C, Pallardy S (1991) Shade Effects on Growth of Tall Fescue: II. Leaf Gas Exchange Characteristics. Crop Sci 31:167-172

Améndola L, Solorio FJ, Ku-Vera JC, et al (2015) Social behaviour of cattle in tropical silvopastoral and monoculture systems. Animal 10:863-867. doi: $10.1017 / \mathrm{s} 1751731115002475$

Andrade CMS de, Valentim JF, Carneiro J da C, Vaz FA (2004) Crescimento de gramíneas e leguminosas forrageiras tropicais sob sombreamento. Pesqui Agropecuária Bras 39:263-270. doi: 10.1590/S0100-204X2004000300009

Andrade HJ, Brook R, Ibrahim M (2008) Growth, production and carbon sequestration of silvopastoral systems with native timber species in the dry lowlands of Costa Rica. Plant Soil 308:11-22. doi: 10.1007/s11104-008-9600-x

Annighöfer P (2018) Stress relief through gap creation ? Growth response of a shade tolerant species (Fagus sylvatica L .) to a changed light environment. For Ecol Manage 415-416:139-147. doi: 10.1016/j.foreco.2018.02.027

Armand D, Meuret M (1993) Du mûrier fourrager dans les systèmes d'élevage ovin préalpin. In: Fodder trees and shrubs in the Mediterranean production systems: Objectives and expected results of the $€ C$ research contract, Agricultur. pp 53-59

Atta-Krah A, Reynolds L (1989) Utilization of pasture and fodder shrubs in the nutrition of sheep and goats in the humid tropics of West Africa. In: Sheep and goat meat production in the humid tropics of West Africa. Rome, Italy

Bacab HM, Solorio FJ, Solorio SB (2012) Efecto de la altura de poda en Leucaena leucocephala y su influencia en el rebrote y rendimiento de Panicum maximum. Av en Investig Agropecu 16:65-77

Beedy TL, Snapp SS, Akinnifesi FK, Sileshi GW (2010) Impact of Gliricidia sepium intercropping on soil organic matter fractions in a maize-based cropping system. Agric Ecosyst Environ 138:139-146. doi: 10.1016/j.agee.2010.04.008

Belesky DP (2005) Growth of Dactylis glomerata along a light gradient in the central Appalachian region of the eastern USA: I. Dry matter production and partitioning. Agrofor Syst 65:81-90. doi: 10.1007/s10457-004-5725-y

Belsky A (1994) Influences of Trees on Savanna Productivity : Tests of Shade, Nutrients 
, and Tree-Grass Competition. Ecology 75:922-932

Belsky AJ, Amundson RG, Duxbury JM, et al (1989) The Effects of Trees on Their Physical , Chemical and Biological Environments in a Semi- Arid Savanna in Kenya. J Appl Ecol 26:1005-1024. doi: 10.1098/rstb.1981.0005

Bertness MD, Callaway R (1994) Positive interactions in communities. Trends Ecol Evol 9:187-191. doi: 10.1016/0169-5347(94)90087-6

Blackshaw JK, Blackshaw AW (1994) Heat stress in cattle and the effect of shade on production and behaviour: A review. Aust J Exp Agric 34:285-295. doi: 10.1071/EA9940285

Braga GJ, Maciel GA, Ramos AKB, et al (2014) Dry matter yield of promising Panicum maximum genotypes in response to phosphorus and lime on Brazilian savanna. Trop Grasslands - Forrajes Trop 2:18. doi: 10.17138/TGFT(2)18-20

Brâncio PA, Nascimento Junior D do, Euclides VPB, et al (2002) Avaliação de Três Cultivares de Panicum maximum Jacq . sob Pastejo . Composição química e digestibilidade da forragem (Evaluation of Three Cultivars of Panicum maximum Jacq. under Grazing. Chemical Composition and in Vitro Organic Matter Digestibility). Rev Bras Zootec 31:1605-1613. doi: 10.1590/S151635982003000500003

Brâncio PA, Pacheco V, Euclides B, et al (2003) Avaliação de Três Cultivares de Panicum maximum Jacq . sob Pastejo : Disponibilidade de Forra- gem, Altura do Resíduo Pós-Pastejo e Participação de Folhas, Colmos e Material Morto 1 (Evaluation of Three Cultivars of Panicum maximum Jacq. under Grazing: . Rev Bras Zootec 32:55-63

Bretfeld M, Ewers BE, Hall JS (2018) Plant water use responses along secondary forest succession during the 2015-2016 El Niño drought in Panama. New Phytol 2:. doi: 10.1111/nph.15071

Breugel M Van, Hall JS, Craven DJ, et al (2011) Early growth and survival of 49 tropical tree species across sites differing in soil fertility and rainfall in Panama. For Ecol Manage 261:1580-1589. doi: 10.1016/j.foreco.2010.08.019

Brooker R, Callaghan T (1998) The Balance between Positive and Negative Plant Interactions and Its Relationship to Environmental Gradients : A Model. Oikos 81:196-207

Broom DM, Galindo FA, Murgueitio E (2013) Biodiversity and good welfare for animals. Sustainable, efficient livestock production with high biodiversity and good welfare for animals. Proc R Soc 280:1-9

Brosi BJ, Armsworth PR, Daily GC (2008) Optimal design of agricultural landscapes for pollination services. Conserv Lett 1:27-36. doi: 10.1111/j.1755-263x.2008.00004.x

Bruijnzeel LA (2004) Hydrological functions of tropical forests: not seeing the soil for the trees?

Buergler AL, Feldhake CR, Teutsch CD, et al (2005) Botanical Composition and Forage Production in an Emulated Silvopasture. Agron J 97:1141. doi: 10.2134/agronj2004.0308

Buergler AL, Fike JH, Burger J a., et al (2006) Forage nutritive value in an emulated silvopasture. Agron J 98:1265-1273. doi: 10.2134/agronj2005.0199

Burgess KS, Husband BC (2006) Habitat differentiation and the ecological costs of hybridization: The effects of introduced mulberry (Morus alba) on a native congener 
(M. rubra). J Ecol 94:1061-1069. doi: 10.1111/j.1365-2745.2006.01152.x

Burner D, Burke J (2012) Survival of bristly locust (Robinia hispida L.) in an emulated organic silvopasture. Nativ Plants J 13:195-200

Burton P, Bazzaz F (1991) Tree seedling emergence on interactive temperature and moisture gradients and in patches of old-field vegetation. Am J Bot 78:131-149. doi: $10.2307 / 2445236$

Bustamante J, Ibrahim M, Beer J (1998) Agronomic evaluation of eight improved grasses grown in silvopastoral systems with Erythrina poeppigiana in the humid tropics of Turrialba, Costa Rica . Agroforestería en las Américas 5:11-16

Cahill JF, McNickle GG, Haag JJ, et al (2010) Plants integrate information about nutrients and neighbors. Science (80- ) 328:1657. doi: 10.1126/science.1189736

Calder IR, Amezaga J, Aylward B, et al (2004) Forest and water policies: The need to reconcile public and science perceptions. Geol Acta 2:157-166

Calle Z (2013) A Strategy for Scaling-Up Intensive Silvopastoral Systems in Colombia. J Sustain For 32:677-693

Calle Z, Murgueitio E, Chara J (2012a) Integrating forestry, sustainable cattle-ranching and landscape restoration. Unasylva 63:31-40

Calle Z, Murgueitio E, Chará J (2012b) Integrating forestry, sustainable cattle-ranching and landscape restoration. Unasylva 63:31-40

Cardona CAC, Ramírez JFN, Morales AMT, et al (2013) Contribution of intensive silvopastoral systems to animal performance and to adaptation and mitigation of climate change. Rev Colomb Ciencias Pecu 27:76-94

Carpenter, SR, Caraca, NF, Correll DL, Howarth, RW, SHarpley, AN, and Smith V (1998) Nonpoint Pollution of Surface Waters with Phosphorus and Nitrogen. Ecol Soc Am 8:559-568

Casals P, Romero J, Rusch GM, Ibrahim M (2013) Soil organic C and nutrient contents under trees with different functional characteristics in seasonally dry tropical silvopastures. Plant Soil 374:643-659. doi: 10.1007/s11104-013-1884-9

Cecato U, Machado AO, Martins EN, et al (2000) Avaliação da produção e de algumas características da rebrota de cultivares e acessos de Panicum maximum Jacq . sob duas alturas de corte. Rev Bras Zootec 29:660-668. doi: 10.1590/S151635982000000300004

Chadhocar P, Kantharaju H (1980) Effect of Gliricidia maculata on growth and breeding of Bannur ewes. Trop Grasslands 14:78-82

Chee Y, Faiz A (1991) Forage Resources in Malaysian Rubber Estates. In: Shelton H, Stur W (eds) Forages for Plantation Crops. Bali, Indonesia, p 168

Cobo JG, Barrios E, Kass DCL, Thomas RJ (2002) Decomposition and nutrient release by green manures in a tropical hillside agroecosystem. Plant Soil 240:331-342. doi: 10.1023/A:1015720324392

Cong WF, Hoffland E, Li L, et al (2015) Intercropping affects the rate of decomposition of soil organic matter and root litter. Plant Soil 391:399-411. doi: 10.1007/s11104015-2433-5

Cortez A (2013) Ganaderos y el MIDA no concuerdan en cifras de reses muertas en Azuero. La Prensa

Costa JO, Leite RC, Toth G, et al (2013) Parasitic helminth infection in young cattle raised on silvopasture and open-pasture in Southeastern Brazil. Agrofor Syst 88:53- 
62. doi: $10.1007 / \mathrm{s} 10457-013-9655-4$

Craven D, Cerdeño N, Mariscal E, et al (2011) Amelioration of growing conditions in mixed species plantation of Terminalia Amazonia and nitrogen-fixing Dalbergia Retusa. Restoring Degrad landscapes with Nativ species Lat Am 63-79

Cribb J (2010) The Coming Famine: The Global Food Crisis And What We Can Do To Avoid It. University of California Press, Berkeley, CA, USA

Dai A (2013) Increasing drought under global warming in observations and models. Nat Clim Chang 3:52-58. doi: 10.1038/nclimate1633

Dailey D (2018) Missouri's 2018 Drought Differs from 2012 in Varied Impact. In: Drovers Driv. Beef Mark. https://www.drovers.com/article/missouris-2018-droughtdiffers-2012-varied-impact. Accessed 4 Feb 2019

Dalzell S, Shelton H, Mullen B, et al (2006) Leucaena: a guide to establishment and management. Sydney: Meat \& Livestock Australia Ltd; 2006. Meat and Livestock Australia, Sydney, Australia

Daudin D, Sierra J (2008) Spatial and temporal variation of below-ground N transfer from a leguminous tree to an associated grass in an agroforestry system. Agric Ecosyst Environ 126:275-280. doi: 10.1016/j.agee.2008.02.009

de Fraiture C, Molden D, Wichelns D (2010) Investing in water for food, ecosystems, and livelihoods: An overview of the comprehensive assessment of water management in agriculture. Agric Water Manag 97:495-501. doi: 10.1016/j.agwat.2009.08.015

De la Cruz R, Manalo M, Aggangan N, Tambalo J (1988) Growth of three legume trees inoculated with VA mycorrhizal fungi and Rhizobium. Plant Soil 108:111-115

de M. Costa SB, de Mello ACL, Dubeux Jr. JC., et al (2016) Livestock Performance in Warm-Climate Silvopastures Using Tree Legumes. Agron J 108:2026. doi: 10.2134/agronj2016.03.0180

DeBruyne SA, Feldhake CM, Burger JA, Fike JH (2011) Tree effects on forage growth and soil water in an Appalachian silvopasture. Agrofor Syst 83:189-200. doi: 10.1007/s10457-011-9376-5

Delgado C, Rosegrant M, Steinfeld H, et al (1999) Live stock to 2020: the next food revolution. Washington, DC USA

Devendra C (2012) Intensification of Integrated Natural Resources Use and Agricultural Systems in the Developing World. Agrotechnology 01:1-4. doi: 10.4172/21689881.1000e101

Devendra C, Ibrahim M (1999) Silvopastoral Systems as a Strategy for Diversification and Productivity Enhancement from Livestock in the Tropics. 2020:8-22

Devkota NR, Wall AJ, Kemp PD, et al (2001) Relationship between canopy closure and pasture production in deciduous tree based temperate silvopastoral systems

Dohn J, Dembélé F, Karembé M, et al (2013) Tree effects on grass growth in savannas: Competition, facilitation and the stress-gradient hypothesis. J Ecol 101:202-209. doi: $10.1111 / 1365-2745.12010$

Dubeux Junior JCB, Muir JP, Apolinário VX de O, et al (2017) Tree legumes: An underexploited resource in warm-climate silvopastures. Rev Bras Zootec 46:689703. doi: 10.1590/S1806-92902017000800010

Duguma B, Kang BT, Okali DUU (1988) Effect of pruning intensities of three woody leguminous species grown in alley cropping with maize and cowpea on an alfisol. Agrofor Syst 6:19-35. doi: 10.1007/BF02344743 
Durr P (2010) The biology, ecology and agroforestry potential of the raintree, Samanea saman (Jacq.) Merr. Agrofor Syst 51:223-237. doi: 10.1023/A

Duvic-Paoli LA (2017) The Intergovernmental Science-Policy Platform for Biodiversity and Ecosystem Services or the Framing of Scientific Knowledge within the Law of Sustainable Development. Int Community Law Rev 19:231-269. doi: 10.1163/18719732-12341355

Espinoza E, Benavides J, Ferreire P (1999) Evaluación de tres variedades de morera (Morus alba) en tres sitios ecológicos de Costa Rica y bajo tres niveles de fertilización

Euclides VPB, Montagner DB, Difante G dos S, et al (2014) Sward structure and livestock performance in guinea grass $\mathrm{cv}$. Tanzania pastures managed by rotational stocking strategies. Sci Agric 71:451-457. doi: 10.1039/b711226b

Ewel JJ (1977) Differences between wet and dry successional tropical ecosystems. Geo. Eco. Trop. 1:103-117

FAO (2009) The State of Food and Agriculture: Livestock in the Balance

FAOSTAT (2010) Food and Agricultural Commodities Production. Rome, Italy

Farley KA, Jobbagy EG, Jackson RB (2005) Effects of afforestation on water yield: a global synthesis with implications for policy. Glob Chang Biol 11:1565-1576. doi: 10.1111/j.1365-2486.2005.01011.x

Feldhake CM, Neel JPS, Belesky DP (2010) Establishment and production from thinned mature deciduous-forest silvopastures in Appalachia. Agrofor Syst 79:31-37. doi: 10.1007/s10457-010-9289-8

Fernandes FD, Ramos AKB, Jank L, et al (2014) Forage yield and nutritive value of Panicum maximum genotypes in the Brazilian savannah. Sci Agric 71:23-29. doi: 10.1007/s00028-010-0082-y

Fischer a., Vasseur L (2002) Smallholder perceptions of agroforestry projects in Panama. Agrofor Syst 54:103-113. doi: 10.1023/A:1015047404867

Flack S (2016) The Art and Science of Grazing: How Grass Farmers Can Create Sustainable Systems for Healthy Animals and Farm Ecosystems. ,. Chelsea Green Publishing, White River Juntion, VT USA

Foley JA (2005) Global Consequences of Land Use. Science (80- ) 309:570-574. doi: 10.1126/science. 1111772

Forestier S, Alvarado G, Badjel Badjel S, Lesueur D (2001) Effect of Rhizobium inoculation methodologies on nodulation and growth of Leucaena leucocephala. World J Microbiol Biotechnol 17:359-362. doi: 10.1023/A:1016627012296

Forwood JR, Owensby CE (1985) Nutritive Value of Tree Leaves in the Kansas. J Range Manag 38:61-64

Francisco I, Arias M, Cortiñas FJ, et al (2009) Silvopastoralism and autochthonous equine livestock: Analysis of the infection by endoparasites. Vet Parasitol 164:357362. doi: 10.1016/j.vetpar.2009.06.018

Fukui K (2000) Effects of Temperature on Growth and Dry Matter Accumulation in Mulberry Saplings. Plant Prod Sci 3:404-409. doi: 10.1626/

Gachengo CN, Palm CA, Jama B, Othieno C (1998) Tithonia and senna green manures and inorganic fertilizers as phosphorus sources for maize in Western Kenya. Agrofor Syst 44:21-36. doi: 10.1023/A:1006123404071

Galindo F, Olea R, Suzán G (2013) Animal welfare and sustainability. In: International 
Workshop on Farm Animal Welfare. Sao Paolo, SP Brazil

Gardi C, Angelini M, Barcelo S, et al (2015) Soil Atlas of Latin America and the Caribbean, European Commission. Office of the European Union, L-2995, Luxembourg

Garen EJ, Saltonstall K, Ashton MS, et al (2011) The tree planting and protecting culture of cattle ranchers and small-scale agriculturalists in rural Panama: Opportunities for reforestation and land restoration. For Ecol Manage 261:1684-1695. doi: 10.1016/j.foreco.2010.10.011

Garen EJ, Saltonstall K, Slusser JL, et al (2009) An evaluation of farmers' experiences planting native trees in rural Panama: implications for reforestation with native species in agricultural landscapes. Agrofor Syst 76:219-236. doi: 10.1007/s10457009-9203-4

Garnett T (2009) Livestock-related greenhouse gas emissions: impacts and options for policy makers. Environ Sci Policy 12:491-503. doi: 10.1016/j.envsci.2009.01.006

Garrett H, Kerley M, Ladyman K, et al (2004) Hardwood silvopasture management in NA: New vistas in Agroforestry. Agrofor Syst 61:21-33. doi: 10.1023/B

Garrity DP, Akinnifesi FK, Ajayi OC, et al (2010) Evergreen Agriculture: a robust approach to sustainable food security in Africa. Food Secur 2:197-214. doi: 10.1007/s12571-010-0070-7

George TS, Gregory PJ, Robinson JS, et al (2001) Tithonia diversifolia: Variations in leaf nutrient concentration and implications for biomass transfer. Agrofor Syst 52:199205. doi: 10.1023/A:1011896705132

George TS, Gregory PJ, Robinson JS, Buresh RJ (2002) Changes in phosphorus concentrations and $\mathrm{pH}$ in the rhizosphere of some agroforestry and crop species. Plant Soil 65-73. doi: 10.1023/A:1021523515707

Gerrish J (2004) Management-intensive Grazing: The Grassroots of Grass Farming. Green Park Press, Ridgeland, MO, USA

Giraldo C, Escobar F, Chará JD, Calle Z (2011) The adoption of silvopastoral systems promotes the recovery of ecological processes regulated by dung beetles in the Colombian Andes. Insect Conserv Divers 4:115-122. doi: 10.1111/j.17524598.2010.00112.x

Godfray HCJ, Beddington JR, Crute IR, et al (2010) Food security: The challenge of feeding 9 billion people. Science (80- ) 327:812-818. doi: 10.1126/science.1185383

Gold MA, Hanover JW (1993) Honeylocust (Gleditsia triacanthos), a multipurpose tree for the temperate zone. Int Tree Crop J 7:189-207. doi:

$10.1080 / 01435698.1993 .9752919$

Gong L, Ren D, Wang Y (1995) Studies on the solar energy utilization of mulberry fields with different planting densities. Sericologia 35:497-505

Griscom HP, Ashton MS (2011a) Restoration of dry tropical forests in Central America: A review of pattern and process. For Ecol Manage 261:1564-1579. doi: 10.1016/j.foreco.2010.08.027

Griscom HP, Ashton MS (2011b) Restoration of dry tropical forests in Central America: A review of pattern and process. For Ecol Manage 261:1564-1579. doi: 10.1016/j.foreco.2010.08.027

Griscom HP, Connelly a. B, Ashton MS, et al (2011) The Structure and Composition of a Tropical Dry Forest Landscape After Land Clearance; Azuero Peninsula, Panama. 
J Sustain For 30:756-774. doi: 10.1080/10549811.2011.571589

Griscom HP, Griscom BW, Ashton MS (2009) Forest regeneration from pasture in the dry tropics of Panama: Effects of cattle, exotic grass, and forested riparia. Restor Ecol 17:117-126. doi: 10.1111/j.1526-100X.2007.00342.x

Growers CRF (1997) Mulberry. https://crfg.org/wiki/fruit/mulberry/. Accessed 4 Feb 2019

Gustin G (2012) "Extreme" drought conditions grip most of Missouri. In: St Louis PostDispatch. https://www.stltoday.com/business/local/extreme-drought-conditions-gripmost-of-missouri/article_fa1b3dae-dcca-11e1-82bf-0019bb30f31a.html. Accessed 4 Feb 2019

Hahlbrock K (2009) Feeding the Planet: Environmental Protection Through Sustainable Agriculture. Haus Publishing, London, UK (translated by D. Skogley). Haus Publishing, London, UK

Hahn Niman N (2014) Defending Beef: The Case for Sustainable Meat Production. Chelsea Green Publishing, White River Juntion, VT USA

Hall JS, Ashton MS, Garen EJ, Jose S (2011a) The ecology and ecosystem services of native trees: Implications for reforestation and land restoration in Mesoamerica. For Ecol Manage 261:1553-1557. doi: 10.1016/j.foreco.2010.12.011

Hall JS, Love BE, Garen EJ, et al (2011b) Tree plantations on farms: Evaluating growth and potential for success. For Ecol Manage 261:1675-1683. doi: 10.1016/j.foreco.2010.09.042

Hanson H (1917) Leaf-structure as related to environment. Am J Bot 4:533-560

Hernández M, Guenni O (2008) Producción de biomasa y calidad nutricional del estrato graminoide en un sistema silvopastoril dominado por samán ( Samanea saman ( Jacq ) Merr ). Zootec Trop 26:439-453

Holdridge LR (1967) Life Zone Ecology. Tropical Science Center, San Jose, Costa Rica

Huang X, Liu Y, Li J, et al (2013) The response of mulberry trees after seedling hardening to summer drought in the hydro-fluctuation belt of Three Gorges Reservoir Areas. Environ Sci Pollut Res 20:7103-7111. doi: 10.1007/s11356-0121395-x

Ibrahim M, Guerra L, Casasola F, Neely C (2010) Importance of silvopastoral systems for mitigation of climate change and harnessing of environmental benefits. 189-196

Ibrahim M, Villanueva C, Casasola F, Rojas J (2007) Sistemas silvopastoriles como una herramienta para el mejoramiento de la productividad y rehabilitación ecológica de paisajes ganaderos en Centro América. Arch Latinoam Prod Anim Vol 15 15:14. doi: $10.1002 / \mathrm{mc} .21974$

Ilstedt U, Bargués Tobella A, Bazié HR, et al (2016) Intermediate tree cover can maximize groundwater recharge in the seasonally dry tropics. Sci Rep 6:1-12. doi: $10.1038 /$ srep21930

Ilstedt U, Malmer A, Verbeeten E, Murdiyarso D (2007) The effect of afforestation on water infiltration in the tropics: A systematic review and meta-analysis. For Ecol Manage 251:45-51. doi: 10.1016/j.foreco.2007.06.014

Jalonen R, Nygren P, Sierra J (2009a) Transfer of nitrogen from a tropical legume tree to an associated fodder grass via root exudation and common mycelial networks. Plant, Cell Environ 32:1366-1376. doi: 10.1111/j.1365-3040.2009.02004.x

Jalonen R, Nygren P, Sierra J (2009b) Root exudates of a legume tree as a nitrogen 
source for a tropical fodder grass. Nutr Cycl Agroecosystems 85:203-213. doi: 10.1007/s10705-009-9259-6

Jama B, Palm C, Buresh R, et al (2000) Tithonia diversifolia as a green manure for soil fertility improvement in western Kenya: A review. Agrofor Syst 49:201-221. doi: 10.1023/A:1006339025728

Janzen D (1977) Intensity of predation on Pithecellobium saman (Leguminosae) seeds by Merobruchus columbinus and St. Torlimbatus (Bruchidae) in a Costa Rican deciduous forest. Trop Ecol 18:162-176

Janzen HH (2004) Carbon cycling in earth systems - A soil science perspective. Agric Ecosyst Environ 104:399-417. doi: 10.1016/j.agee.2004.01.040

Janzen HH (2011) What place for livestock on a re-greening earth? Anim Feed Sci Technol 166-167:783-796. doi: 10.1016/j.anifeedsci.2011.04.055

Joffre R, Rambal S (1993) How Tree Cover Influences the Water Balance of Mediterranean Rangelands. Ecology 74:570-582

Johnson J, Fike J, Fike W, et al (2013) Millwood honeylocust trees: seedpod nutritive value and yield characteristics. Agrofor Syst 87:849-856. doi: 10.1007/s10457-0139601-5

Jones W, Anderson L, Ross M (1973) Bloat in cattle. New Zeal J Agric Res 16:441-446. doi: $10.1080 / 00288233.1973 .10421128$

Jose, S., Walter, D. and Kumar B. (2017) Ecological considerations in sustainable silvopasture design and management. Agrofor Syst. doi: 10.1007/s10457-016-00652

Jose S, Gillespie a. R, Pallardy SG (2004) Interspecific interactions in temperate agroforestry. Agrofor Syst 61-62:237-255. doi: 10.1023/B:AGFO.0000029002.85273.9b

Jose S, Williams R, Zamora D (2006) Belowground ecological interactions in mixedspecies forest plantations. For Ecol Manage 233:231-239. doi: 10.1016/j.foreco.2006.05.014

Kabi F, Bareeba FB (2008) Herbage biomass production and nutritive value of mulberry ( Morus alba ) and Calliandra calothyrsus harvested at different cutting frequencies. 140:178-190. doi: 10.1016/j.anifeedsci.2007.02.011

Kadiata BD (1997) Effect of tree pruning and pruning application to trees on nitrogen fixation by Leucaena and Gliricidia. Agrofor Syst 39:117-128. doi: 10.1023/A:1005957206624

Kallenbach R (2009) Integrating silvopastures into current forage-livestock systems. In: Agroforestry Comes of Age: Putting Science into Practice. pp 455-461

Kallenbach RL, Kerley MS, Bishop-Hurley GJ (2006) Cumulative forage production, forage quality and livestock performance from an annual ryegrass and cereal rye mixture in a Pine Walnut Silvopasture. Agrofor Syst 66:43-53. doi: 10.1007/s10457-005-6640-6

Kallenbach RL, Venable EB, Kerley MS, Bailey NJ (2010) Stockpiled tall fescue and livestock performance in an early stage midwest silvopasture system. Agrofor Syst 80:379-384. doi: 10.1007/s10457-010-9322-y

Kandylis K, Hadjigeorgiou I, Harizanis P (2009) The nutritive value of mulberry leaves (Morus alba) as a feed supplement for sheep. Trop Anim Health Prod 41:17-24. doi: $10.1007 / \mathrm{s} 11250-008-9149-\mathrm{y}$ 
Kannan R (2018) Avian Frugivory in a Fruiting Mulberry Tree ( Morus rubra ) in Arkansas. 72:38-46

Karki U, Goodman MS (2015) Microclimatic differences between mature loblolly-pine silvopasture and open-pasture. Agrofor Syst 89:319-325. doi: 10.1007/s10457-0149768-4

Karki U, Goodman MS (2010) Cattle distribution and behavior in southern-pine silvopasture versus open-pasture. Agrofor Syst 78:159-168. doi: 10.1007/s10457009-9250-x

Kellman M (1979) Soil Enrichment by Neotropical Savanna Trees. J Ecol 67:565-577

Kelty MJ (2006) The role of species mixtures in plantation forestry. For Ecol Manage 233:195-204. doi: 10.1016/j.foreco.2006.05.011

Kendall PE, Nielsen PP, Webster JR, et al (2006) The effects of providing shade to lactating dairy cows in a temperate climate. Livest Sci 103:148-157. doi: 10.1016/j.livsci.2006.02.004

Kephart K, Buxton D (1993) Forage Quality Responses of C3 and C4 Perennial Grasses to Shade. Crop Sci 33:831-837

Kikvidze Z, Armas C (2010) Plant interaction indices based on experimental plant performance data. Posit Plant Interact Community Dyn 17-37. doi: $10.1201 / 9781439824955$

Krieb KB, Pacala S (2012) Can Reforestation Restore Soil Quality? The Effects of Pasture Abandonment on Soil Chemistry in the Azuero Peninsula , Panama

Kumar BM, George SJ, Suresh TK (2001) Fodder grass productivity and soil fertility changes under four grass +tree associations in Kerala, India. Agrofor Syst 52:91106. doi: 10.1023/A:1010756018265

Ladyman KP, Kerley MS, Kallenbach RL, et al (2003) Quality and Quantity Evaluations of Shade Grown Forages. Notes

Lamb D, Erskine PD, Parrotta J a (2005) R EVIEW Restoration of Degraded Tropical Forest Landscapes. 1628-1632. doi: 10.1126/science.1111773

Leafscan (2019) Leafscan. In: Leafscan App. https://www.leafscanapp.com/. Accessed 14 Feb 2019

Lehmann J, Peter I, Steglich C, et al (1998) Below-ground interactions in dryland agroforestry. For Ecol Manage 111:157-169. doi: 10.1016/S0378-1127(98)00322-3

León JD, Osorio NW (2014) Role of Litter Turnover in Soil Quality in Tropical Degraded Lands of Colombia. Sci World J 2014:1-11. doi: 10.1155/2014/693981

Li YY, Shao MA (2006) Change of soil physical properties under long-term natural vegetation restoration in the Loess Plateau of China. J Arid Environ 64:77-96. doi: 10.1016/j.jaridenv.2005.04.005

Lin BB (2010) The role of agroforestry in reducing water loss through soil evaporation and crop transpiration in coffee agroecosystems. Agric For Meteorol 150:510-518. doi: 10.1016/j.agrformet.2009.11.010

Lin C, McGraw R, George M, Garrett H (1998) Shade effects on forage crops with potential in temperate agroforestry practices. Agrofor Syst 44:109-119. doi: 10.1023/A:1006205116354

Lin CH, Mcgraw ML, George MF, Garrett HE (2001) Nutritive quality and morphological development under partial shade of some forage species with agroforestry potential. Agrofor Syst 53:269-281. doi: 10.1023/A:1013323409839 
Liyanage ADES, Jayasundara HPS, Fernando DNS, Fernando MTN (1993) Integration of legume-based pasture and cattle into coconut farming systems in Sri Lanka. J Asian Farming Syst 1:579-588

Loach K (1970) Shade Tolerance in Tree Seedlings. New Phytol 69:273-286

Lovell ST, Wilson MH (2017) Multifunctional Perennial Cropping Systems Supplemental Design Information

Macedo MO, Resende AS, Garcia PC, et al (2008) Changes in soil C and N stocks and nutrient dynamics 13 years after recovery of degraded land using leguminous nitrogen-fixing trees. For Ecol Manage 255:1516-1524. doi: 10.1016/j.foreco.2007.11.007

Mafongoya P, Nair P (1997) Multipurpose tree prunings as a source of nitrogen to maize under semiarid conditions in Zimbabwe. 1. Nitrogen recovery in relation to pruning quality and method of application. 35:31-46

Mafongoya PL, Bationo A, Kihara J, Waswa BS (2006) Appropriate technologies to replenish soil fertility in southern Africa. Nutr Cycl Agroecosystems 76:137-151. doi: 10.1007/s10705-006-9049-3

Makkar H (1989) Relationship of rumen degradability with microbial colonization, cell wall constituents and tannin levels in some tree leaves. Anim Prod 49:

Malmer A, Murdiyarso D, (Sampurno) Bruijnzeel L, Ilstedt U (2010) Carbon sequestration in tropical forests and water: a critical look at the basis for commonly used generalizations. Glob Chang Biol 16:599-604. doi: 10.1111/j.13652486.2009.01984.x

Manríquez-Mendoza L, López-Ortiz S, Olguín-Palacios C, et al (2011) Productivity of a Silvopastoral System Under Intensive Mixed Species Grazing By Cattle and Sheep. Trop Subtrop Agroecosystems 13:573-584

Martin A, Zim H, Nelson A (1961) Mulberry family: Moraceae. In: American wildlife and plants. Dover Publications, New York, USA, pp 313-314

Matson PA (1997) Agricultural Intensification and Ecosystem Properties. Science (80- ) 277:504-509. doi: 10.1126/science.277.5325.504

Mbow C, Noordwijk M Van, Luedeling E, et al (2014) Agroforestry solutions to address food security and climate change challenges in Africa. Curr Opin Environ Sustain 6:61-67. doi: 10.1016/j.cosust.2013.10.014

McArthur AJ (1991) Forestry and Shelter for Livestock. 93-107

McClendon J, McMillen G (1982) The Control of Leaf Morphology and the Tolerance of Shade by Woody Plants. Bot Gaz 143:79-83. doi: 10.1086/337273

McDermott ME, Rodewald AD (2014) Conservation value of silvopastures to Neotropical migrants in Andean forest flocks. Biol Conserv 175:140-147. doi: 10.1016/j.biocon.2014.04.027

McIlvain EH, Shoop MC (1971) Shade for Improving Cattle Gains and Rangeland Use. J Rnage Manag 24:181-184

Medinilla-Salinas L, Vargas-Mendoza MD la C, López-Ortiz S, et al (2013) Growth, productivity and quality of Megathyrsus maximus under cover from Gliricidia sepium. Agrofor Syst 87:891-899. doi: 10.1007/s10457-013-9605-1

Mehlich A (1984) Mehlich 3 Soil Test Extractant: A Modification of Mehlich 2 Extractant. Commun Soil Sci Plant Anal 15:1409-1416. doi: $10.1080 / 00103628409367568$ 
Minnemeyer S, Laestadius L, Sizer N, et al (2011) A world of opportunity. Washington, DC, World Resources Institute. Available at: www.wri.org/restoringforests. Washington, DC

Mitlöhner FM, Morrow JL, Dailey JW, et al (2001) Shade and water misting effects on behavior, physiology, performance, and carcass traits of heat-stressed feedlot cattle. J Anim Sci 79:2327-2335. doi: 10.2527/2001.7992327x

Moore KM, Barry TN, Cameron PN, et al (2003) Willow ( Salix sp .) as a supplement for grazing cattle under drought conditions. 104:1-11. doi: 10.1016/S03778401(02)00326-7

Morrison BJ, Gold MA, Lantagne DO (1996) Incorporating indigenous knowledge of fodder trees into small-scale silvopastoral systems in Jamaica. 101-117

Moustakas A, Kunin WE, Cameron TC, Sankaran M (2013) Facilitation or Competition? Tree Effects on Grass Biomass across a Precipitation Gradient. PLoS One 8:. doi: 10.1371/journal.pone.0057025

Mueller J, Luginbuhl J-M, Bergmann B (2001) Establishment and early growth characteristics of six Paulownia genotypes for goat browse in Raleigh, NC, USA. Agrofor Syst 52:63-72. doi: 10.1023/A

Muir J, Jank L (2004) Warm-Season (C4) Grasses. Madison, WI 54711

Munroe J, Isaac M (2014) N2-fixing trees and the transfer of fixed-N for sustainable agroforestry: A review. Agron Sustain Dev 34:417-427

Murgueitio E, Calle Z, Uribe F, et al (2011) Native trees and shrubs for the productive rehabilitation of tropical cattle ranching lands. For Ecol Manage 261:1654-1663. doi: 10.1016/j.foreco.2010.09.027

Mutuo P (2000) Soil phosphorus pools following phosphorus fertilization and their relation- ship to maize yield in western Kenya. Moi University, Eldoret, Kenya

Neel, J.P.S. and Belesky DP (2015) Herbage production , nutritive value and animal productivity within hardwood silvopasture, open and mixed pasture systems in Appalachia, United States. Grass Forage Sci 72:137-153. doi: 10.1111/gfs.12211

Neel JPS, Belesky DP (2017) Herbage production, nutritive value and animal productivity within hardwood silvopasture, open and mixed pasture systems in Appalachia, United States. Grass Forage Sci 72:137-153. doi: 10.1111/gfs.12211

Neill C, Piccolo MC, Steudler PA, et al (1995) Nitrogen dynamics in soils of forests and active pastures in the western Brazilian Amazon Basin. Soil Biol Biochem 27:11671175. doi: 10.1016/0038-0717(95)00036-E

Nieto R, Ribera M, García M, Aguilera J (2002) Amino acid availability and energy value of acorn in the Iberian pig. Livest Prod Sci 77:227-239. Livest Prod Sci $77: 227-239$

Nixon JW (2013) The drought of 2012: Missouri recognizes, responds, recharges

Nygren P, Fernandez MP, Harmand JM, Leblanc HA (2012) Symbiotic dinitrogen fixation by trees: An underestimated resource in agroforestry systems? Nutr Cycl Agroecosystems 94:123-160. doi: 10.1007/s10705-012-9542-9

Nygren P, Leblanc H a. (2009) Natural abundance of $15 \mathrm{~N}$ in two cacao plantations with legume and non-legume shade trees. Agrofor Syst 76:303-315. doi: 10.1007/s10457-008-9160-3

Obispo NE, Espinoza Y, Gil JL, et al (2008) Efecto del sombreado sobre la producción y calidad del pasto guinea (Panicum maximun) en un sistema silvopastoril. Zootec 
Trop 26:285-288

Orefice J, Smith RG, Carroll J, et al (2016) Forage productivity and profitability in newly-established open pasture, silvopasture, and thinned forest production systems. Agrofor Syst 1-15. doi: 10.1007/s10457-016-0052-7

Orefice J, Smith RG, Carroll J, et al (2017) Soil and understory plant dynamics during conversion of forest to silvopasture, open pasture, and woodlot. Agrofor Syst 91:729-739. doi: 10.1007/s10457-016-0040-y

Orefice JN (2015) SILVOPASTURE IN THE NORTHEASTERN UNITED STATES

Otusanya O, Ilori O, Adelusi A (2007) Allelopathic Effects of Tithonia diversifolia (Hemsl) A. Gray on Germination and Growth of Amaranthus cruentus. Res J Environ Sci 1:285-293. doi: 10.1111/ijfs.12122

Paciullo DSC, de Castro CRT, Gomide CA de M, et al (2011) Performance of dairy heifers in a silvopastoral system. Livest Sci 141:166-172. doi: 10.1016/j.livsci.2011.05.012

Paciullo DSC, Gomide CAM, Castro CRT, et al (2017) Morphogenesis, biomass and nutritive value of Panicum maximum under different shade levels and fertilizer nitrogen rates. Grass Forage Sci 72:590-600. doi: 10.1111/gfs.12264

Paciullo DSC, Pires MFA, Aroeira LJM, et al (2014) Sward characteristics and performance of dairy cows in organic grass-legume pastures shaded by tropical trees. Animal 8:1264-1271. doi: 10.1017/S1751731114000767

Pagiola S, Agostini P, Gobbi J, et al (2005) Paying for Biodiversity Conservation Services. Mt Res Dev 25:206-211. doi: 10.1659/02764741(2005)025[0206:PFBCS]2.0.CO;2

Palm C, Myers R, Nandwa S (1997) Combined use of organic and inorganic nutrient source for soil fertility maintenance and replenishment. In: Replenishing soil fertility in Africa. pp 193-217

Panamá, S.A.) E (Empresa TE de (2011) Historical data on mean annual rainfall and temperature in Cañas - Los Santos (1977 - 2011)

Pang K, Van Sambeek JW, Navarrete-Tindall NE, et al (2019) Responses of legumes and grasses to non-, moderate, and dense shade in Missouri, USA. I. Forage yield and its species-level plasticity. Agrofor Syst 93:11-24. doi: 10.1007/s10457-017-0067-8

Papachristou TG, Papanastasis VP (1994) Forage value of Mediterranean deciduous woody fodder species and its implication to management of silvo-pastoral systems for goats. Agrofor Syst 27:269-282. doi: 10.1007/BF00705061

Papanastasis VP, Yiakoulaki MD, Decandia M, Dini-papanastasi O (2008) Integrating woody species into livestock feeding in the Mediterranean areas of Europe. 140:117. doi: 10.1016/j.anifeedsci.2007.03.012

Partey ST (2011) Effect of pruning frequency and pruning height on the biomass production of Tithonia diversifolia (Hemsl) A. Gray. Agrofor Syst 83:181-187. doi: 10.1007/s10457-010-9367-y

Partey ST, Quashie-Sam SJ, Thevathasan N V., Gordon AM (2011) Decomposition and nutrient release patterns of the leaf biomass of the wild sunflower (Tithonia diversifolia): A comparative study with four leguminous agroforestry species. Agrofor Syst 81:123-134. doi: 10.1007/s10457-010-9360-5

Paul C, Weber M (2016) Effects of planting food crops on survival and early growth of timber trees in eastern Panama. New For 47:53-72. doi: 10.1007/s11056-015-9477- 
5

Pent GJ, Fike JH (2018) Lamb productivity on stockpiled fescue in honeylocust and black walnut silvopastures. Agrofor Syst 93:1-9. doi: 10.1007/s10457-018-0264-0

Pérez J, Zapata B, Sosa R (1995) Brosimum alicastrum Swartz. como forraje en la alimentación de ovinos en crecimiento. Agroforestería en las Américas 2:17-21

Phalan B, Balmford A, Green RE, Scharlemann JPW (2011) Minimising the harm to biodiversity of producing more food globally. Food Policy 36:. doi: 10.1016/j.foodpol.2010.11.008

Piepho HP, Buchse A, Emrich K (2003) A Hitchhiker's Guide to Mixed Models for Randomized Experiments\rdoi:10.1046/j.1439-037X.2003.00049.x. J Agron Crop Sci 189:310-322

Pitta DW, Barry TN, Lopez-villalobos N, Kemp PD (2005) Effects on ewe reproduction of grazing willow fodder blocks during drought. 120:217-234. doi: 10.1016/j.anifeedsci.2005.02.030

Plath M, Mody K, Potvin C, Dorn S (2010) Do multipurpose companion trees affect high value timber trees in a silvopastoral plantation system? Agrofor Syst 81:79-92. doi: $10.1007 / \mathrm{s} 10457-010-9308-9$

Pollen M (2006) The omnivore's dilemma: the search for a perfect meal in a fast-food world. Bloomsburg Publishing, Plc, London, UK

Pretzsch H (2009) Forest Dynamics, Growth and Yield: From Measurement to Model. Springer-Verlag Berlin Heidelberg, Berlin

Pulido F (1999) Herbivorismo y regeneración de la encina (Quercus ilex L.) en bosques y dehesas. Universidad de Extremadura, Cáceres, Spain

Pulido F, Díaz M, Hidalgo S (2001) Size-structure and regeneration of Spanish holm oak Quercus ilex forest and dehesas: effects of agroforestry use on their long-term sustainability. For Ecol Manage 146:1-13

Rao M, Nair P, Ong C (1998) Biophysical interactions in tropical agroforestry systems. Agrofor Syst 38:3-50. doi: 10.1023/A

Rayburn EB (2007) Forage Production for Pasture-Based Livestock Production. , 2007. Natural Resource, Agriculture, and Engineering Service (NRAES)

Reiners WA, Bouwman AF, Parsons WFJ, Keller M (1994) Tropical Rain Forest Conversion to Pasture: Changes in Vegetation and Soil Properties. Ecol Appl 4:363377. doi: $10.2307 / 1941940$

Rich PM, Wood J, Vieglais DA, et al (1999) Hemiview User Manual. Delta-T Devices 85

Richards JH, Caldwell MM (1987) Hydraulic lift: Substantial nocturnal water transport between soil layers by Artemisia tridentata roots. Oecologia 73:486-489. doi: 10.1007/BF00379405

Riedel J, Dorn S, Plath M, Mody K (2012) Growth, herbivore distribution, and herbivore damage of timber trees in a tropical silvopastoral reforestation system. Ann For Sci 70:75-86. doi: 10.1007/s13595-012-0239-7

Rivera LF, Armbrecht I, Calle Z (2013) Silvopastoral systems and ant diversity conservation in a cattle-dominated landscape of the Colombian Andes. Agric Ecosyst Environ 181:188-194. doi: 10.1016/j.agee.2013.09.011

Roberts C (2010) Tall Fescue Toxicosis

Rodríguez-Estévez V, García Martínez A, Perea Muñoz J, et al (2007) Producción de bellota en la dehesa: factores influyentes. Arch Zootec 56:25-43 
Rowlinson P (2008) Adapting livestock production systems to climate change - temperate zones. In: Rowlinson P, Steele M, Nefzaoui A (eds) Livestock and Global Climate Change. Brittish Society of Animal Science, Hammamet, Tunisia, pp 61-67

Ruíz T, Febles G, Galindo J, et al (2014) Tithonia diversifolia, its possibilities in cattle rearing systems. Cuba J Agric Sci 48:79-82

Saddul, D., Jelan, A., Liang, J. B. RAH (2004) The potential of Mulberry as a fodder crop

Saddul D, Jelan ZA, Liang JB, Halim RA (2004) The potential of mulberry (Morus alba) as a fodder crop: The effect of plant maturity on yield, persistence and nutrient composition of plant fractions. Asian-Australasian J Anim Sci 17:1657-1662. doi: 10.5713/ajas.2004.1657

Samarakoon S (1990) Growth, morphology and nutritive quality of shaded Stenotaphrum secundatum, Axonopus compressus and Pennisetum clandestinum. J Agric Sci 114:

Sánchez MD (2000) Mulberry: an exceptional forage available almost worldwide. World Rev Anim Prod 93:1-21

Sandoval-Pérez AL, Gavito ME, García-Oliva F, Jaramillo VJ (2009) Carbon, nitrogen, phosphorus and enzymatic activity under different land uses in a tropical, dry ecosystem. Soil Use Manag 25:419-426. doi: 10.1111/j.1475-2743.2009.00234.x

Sandström K (1998) Can Forests " Provide " Water : Widespread Myth or Scientific Reality? Ambio 27:132-138

Sanginga N, Woomer PL (2009) Integrated soil fertility management in Africa: principles, practices, and developmental processes. TSBF-CIAT, Nairobi

Santiago-Hernández F, López-Ortiz S, Ávila-Reséndiz C, et al (2016) Physiological and production responses of four grasses from the genera Urochloa and Megathyrsus to shade from Melia azedarach L. Agrofor Syst 90:339-349. doi: 10.1007/s10457-0159858-y

Savory A, Butterfield J (2016) Holistic Management: A Commonsense Revolution to Restore Our Environment. Island Press, 2016. Third Edition., 3rd edn. Island Press, Washington, DC USA

Schlönvoigt A, Beer J (2001) Initial growth of pioneer timber tree species in a Taungya system in the humid lowlands of Costa Rica. Agrofor Syst 51:97-108. doi: 10.1023/A:1010674402907

Schofield R, Taylor A (1955) The measurement of soil pH. Soil Sci Soc Am J 19:164167

Schultz H (1996) Water relations and photosynthetic responses of two grapevine cultivars of different geographical origin during water stress. Acta Hortic 427:251-266. doi: 10.17660/ActaHortic. 1996.427.30

Sharma, S. K., Zote KK (2010) Mulberry: A Multi-purpose Tree Species

Sharrow S, Brauer D, Clason T (2009) Silvopastoral Practices. In: North American Agroforestry: An integrated science and practice

Sharrow SH (2007) Soil compaction by grazing livestock in silvopastures as evidenced by changes in soil physical properties. Agrofor Syst 71:215-223. doi: 10.1007/s10457-007-9083-4

Shelton HM, Dalzell SA (2007) Production, economic and environmental benefits of leucaena pastures. Trop Grasslands 41:174-190

Shepard M (2013) Restoration Agriculture: Real-World Permaculture for Farmers. Acres 
U.S.A, Austin, TX

Sierra J, Daudin D, Domenach a. M, et al (2007) Nitrogen transfer from a legume tree to the associated grass estimated by the isotopic signature of tree root exudates: A comparison of the $15 \mathrm{~N}$ leaf feeding and natural $15 \mathrm{~N}$ abundance methods. Eur $\mathrm{J}$ Agron 27:178-186. doi: 10.1016/j.eja.2007.03.003

Sierra J, Nygren P (2006) Transfer of N fixed by a legume tree to the associated grass in a tropical silvopastoral system. Soil Biol Biochem 38:1893-1903. doi: 10.1016/j.soilbio.2005.12.012

Sileshi GW, Mafongoya PL, Akinnifesi FK, et al (2014) Agroforestry: Fertilizer Trees. Encycl Agric Food Syst 222-234. doi: 10.1016/B978-0-444-52512-3.00022-X

Silveira ML, Vendramini JMB, Sellers B, et al (2015) Bahiagrass response and N loss from selected N fertilizer sources. Grass Forage Sci 70:154-160. doi: $10.1111 /$ gfs. 12078

Sloan S (2008) Reforestation amidst deforestation: Simultaneity and succession. Glob Environ Chang 18:425-441. doi: 10.1016/j.gloenvcha.2008.04.009

Snyder CS, Bruulsema TW, Jensen TL, Fixen PE (2009) Review of greenhouse gas emissions from crop production systems and fertilizer management effects. Agric Ecosyst Environ 133:247-266. doi: 10.1016/j.agee.2009.04.021

Sosa Rubio E, Pérez Rodríguez D, Ortega Reyes L, Zapata Buenfil G (2004) Evaluacion del Potencial Forrajero de arboles y arbustos tropicales para la alimentacion. Técnica Pecu en México 42:129-144

Sousa LF, Maurício RM, Moreira GR, et al (2010) Nutritional evaluation of "Braquiarão" grass in association with "Aroeira" trees in a silvopastoral system. Agrofor Syst 79:189-199. doi: 10.1007/s10457-010-9297-8

Staley TE, Gonzalez JM, Neel JPS (2008) Conversion of deciduous forest to silvopasture produces soil properties indicative of rapid transition to improved pasture. Agrofor Syst 74:267-277. doi: 10.1007/s10457-008-9139-0

Steel R, Torrie J (1980) Principles and procedures of statistics: a biometrical approach. McGraw-Hill, New York, USA. 633 p. McGraw-Hill, New York, USA

Steinfeld H, Gerber P, Wassenaar T, et al (2006) Livestock's Long Shadow: Environmental Issues and Options. FAO, Rome, Italy

Talamuci P, Pardini A (1999) Pastoral systems dominated by fodder crops harvesting and grazing. In: Dynamics and sustainability of Mediterranean pastoral systems. pp 2944

Teklehaimanot Z, Jones M, Sinclair FL (2002) Tree and livestock productivity in relation to tree planting configuration in a silvopastoral system in North Wales, UK. Agrofor Syst 56:47-55. doi: 10.1023/A:1021131026092

Thor Smestad B, Tiessen H, Buresh RJ (2002) Short fallows of Tithonia diversifolia and Crotalaria grahamiana for soil fertility improvement in western Kenya. Agrofor Syst 55:181-194. doi: 10.1023/A:1020501627174

Tiedemann AR, Klemmedson JO (2008) Effect of Mesquite on Physical and Chemical Properties of the Soil. J Rangel Manag 26:27-29. doi: 10.2307/3896877

Tongma S, Kobayashi K, Usui K (2001) Allelopathic activity of Mexican sunflower [Tithonia diversifolia (Hemsl.) A. Gray] in soil under natural field conditions and different moisture conditions. Weed Biol Manag 1:115-119. doi: 10.1046/j.14456664.2001.00020.x 
Trenberth KE, Dai A, Van Der Schrier G, et al (2014) Global warming and changes in drought. Nat Clim Chang 4:17-22. doi: 10.1038/nclimate2067

Tscharntke T, Clough Y, Wanger TC, et al (2012) Global food security, biodiversity conservation and the future of agricultural intensification. Biol Conserv 151:53-59. doi: 10.1016/j.biocon.2012.01.068

Tucker CB, Rogers AR, Schütz KE (2008) Effect of solar radiation on dairy cattle behaviour, use of shade and body temperature in a pasture-based system. Appl Anim Behav Sci 109:141-154. doi: 10.1016/j.applanim.2007.03.015

Tudsri S, Prasanpanich S (2001) Effect of pasture production systems on milk production in the central plains of Thailand. 35:246-253

Turner N, Long M (1980) Errors Arising From Rapid Water Loss in the Measurement of Leaf Water Potential by the Pressure Chamber Technique. Aust J Plant Physiol 7:527. doi: 10.1071/PP9800527

Udawatta RP, Jose S (2012) Agroforestry strategies to sequester carbon in temperate North America. Agrofor Syst 86:225-242. doi: 10.1007/s10457-012-9561-1

USDA - NRCS (2010) PRESCRIBED GRAZING - PRACTICE INTRODUCTION practice code 528

Vandermeer J (1989) The ecology of intercropping. Cambridge University Press, Cambridge

Vandermeulen S, Ramírez-Restrepo CA, Beckers Y, et al (2018a) Agroforestry for ruminants: A review of trees and shrubs as fodder in silvopastoral temperate and tropical production systems. Anim Prod Sci 58:767-777. doi: 10.1071/AN16434

Vandermeulen S, Ramírez-Restrepo CA, Marche C, et al (2018b) Behaviour and browse species selectivity of heifers grazing in a temperate silvopastoral system. Agrofor Syst 92:705-716. doi: 10.1007/s10457-016-0041-x

Varah A, Jones H, Smith J, Potts SG (2013) Enhanced biodiversity and pollination in UK agroforestry systems. J Sci Food Agric 93:2073-2075. doi: 10.1002/jsfa.6148

Vetaas OR (1992) Micro-site effects of trees and shrubs in dry savannas. J Veg Sci 3:337-344. doi: $10.2307 / 3235758$

Viáfara B, Clavero T, Araujo-Febres O (1997) Efecto del sombreamiento de samán (Pithecelobium saman JACQ. (BENTH)) sobre el crecimiento y desarrollo del pasto guinea (Panicum maximum JACQ). Arch Latinoam Prod Anim 5:39-41

Vieira DLM, Holl KD, Peneireiro FM (2009) Agro-successional restoration as a strategy to facilitate tropical forest recovery. Restor Ecol 17:451-459. doi: 10.1111/j.1526100X.2009.00570.X

Vitousek PM (2013) Litterfall, Nutrient Cycling, and Nutrient Limitation in Tropical Forests. Ecol Soc Am 65:285-298

Voison A (1988) Grass Productivity. Island Press, Washington, DC USA

Wagner M, Cobbinah J, Ofori D (1996) Companion planting of the nitrogen-fixing Gliricidia sepium with the tropical timber species Milicia excelsa and its impact on the gall forming insect Phyolyma lata. Maui, HI

Webster A (1970) Direct effects of cold weather on the energetic efficiency of beef production in different regions of Canada. Can J Anim Sci 50:563-573

Will RE, Wilson SM, Zou CB, Hennessey TC (2013) Increased vapor pressure deficit due to higher temperature leads to greater transpiration and faster mortality during drought for tree seedlings common to the forest - grassland ecotone 
Wilson J (1996) Shade-stimulated growth and nitrogen uptake by pasture grasses in a subtropical environment. Austalian J Agric Res 47:1075-1093

Wilson JR. b (1998) Influence of planting four tree species on the yield and soil water status of green panic pasture in subhumid south-east Queensland. Trop. Grasslands 32:209-220

Wishnie MH, Dent DH, Mariscal E, et al (2007) Initial performance and reforestation potential of 24 tropical tree species planted across a precipitation gradient in the Republic of Panama. For Ecol Manage 243:39-49. doi: 10.1016/j.foreco.2007.02.001

Xavier DF, da Silva Lédo FJ, de Campos Paciullo DS, et al (2014) Nitrogen cycling in a Brachiaria-based silvopastoral system in the Atlantic forest region of Minas Gerais, Brazil. Nutr Cycl Agroecosystems 99:45-62. doi: 10.1007/s10705-014-9617-X

Yadav A, Gendley MK, Sahu J, Patel PK (2019) Silvopastoral system : A prototype of livestock agroforestry Silvopastoral system : A prototype of livestock agroforestry. Pharma Innov J 8:76-82

Yamamoto W, Dewi IA, Ibrahim M (2007) Effects of silvopastoral areas on milk production at dual-purpose cattle farms at the semi-humid old agricultural frontier in central Nicaragua. Agric Syst 94:368-375. doi: 10.1016/j.agsy.2006.10.011

Yiakoulaki MD (1995) Intake by goats grazing kermes oak shrublands with varying cover in Northern Greece. Small Rumin Res 17:223-228 


\section{APPENDICES}


Appendix A

Protocol for Hemispherical Canopy Photos with the Canon Eos Rebel T5

Helene Muller-Landau, Version September 21, 2014. Adjusted by Lea Bernath, Version March 17, 2015 and later adjusted by Ryan Dibala, Version June 6, 2018.

\section{Things you need to do once before you start taking pictures}

1. Mode of operation: The camera should be in Program mode, represented by the letter $\mathrm{P}$ on the dial on the top right of the camera.

2. File type: The camera should save files in the highest quality formats - both RAW and JPEG. To do this,

O Turn on the camera

- Press the MENU button

○ In the first menu (very left), select the top line, "quality" and press SET

$\circ \quad$ Use the keys to the right and left of the SET button to move among the options and choose RAW + half-circle L

O Press SET

3. Automatic exposure compensation and automatic exposure bracketing: Automatic exposure bracketing makes it easy to take multiple photos on the same site with systematic variation in exposure. Multiple photos at different exposures provide additional information for processing images. Exposure bracketing commands the camera to adjust the default exposure values to several values from lower to higher exposure compensation (darker to lighter). Specifically, we want to take photos at $-2.0,-1.0$, and 0 exposure compensation.

○ Turn on the camera

○ Keep the "Av +/_" button pressed and use the dial on the top right of the camera to set the exposure to -1

o Press the menu button

○ Press to the right of the SET button to move among the menus, to the second menu, where the top line is AEB

- Select AEB, then press SET

O Press to the right of the SET button to separate the three lines so they are at $-2,-1$, and 0

- Press SET

- Every time you turn off the camera you need to set the exposure bracketing again

4. Focus: The lens should be set the manual focus (M) and the focus ring should be set on infinity.

5. Self-timer: It is important that the camera is not moved in any way while the photo is taken and the easiest way to accomplish this is to take the photos using the selftimer so that the operator is not touching the camera at the time the photo is taken.

- Press to the left of the SET button

- Select the 2-second self-timer 
6. Metering mode: Make sure that the metering mode is on "Evaluative Metering." Press the button on top of the SET button to do this.

7. Picture Style: Make sure that the picture style is "Neutral." Press the button below the SET button to do this.

8. Check configuration: When the camera is fully and correctly configured the LCD should look like this:

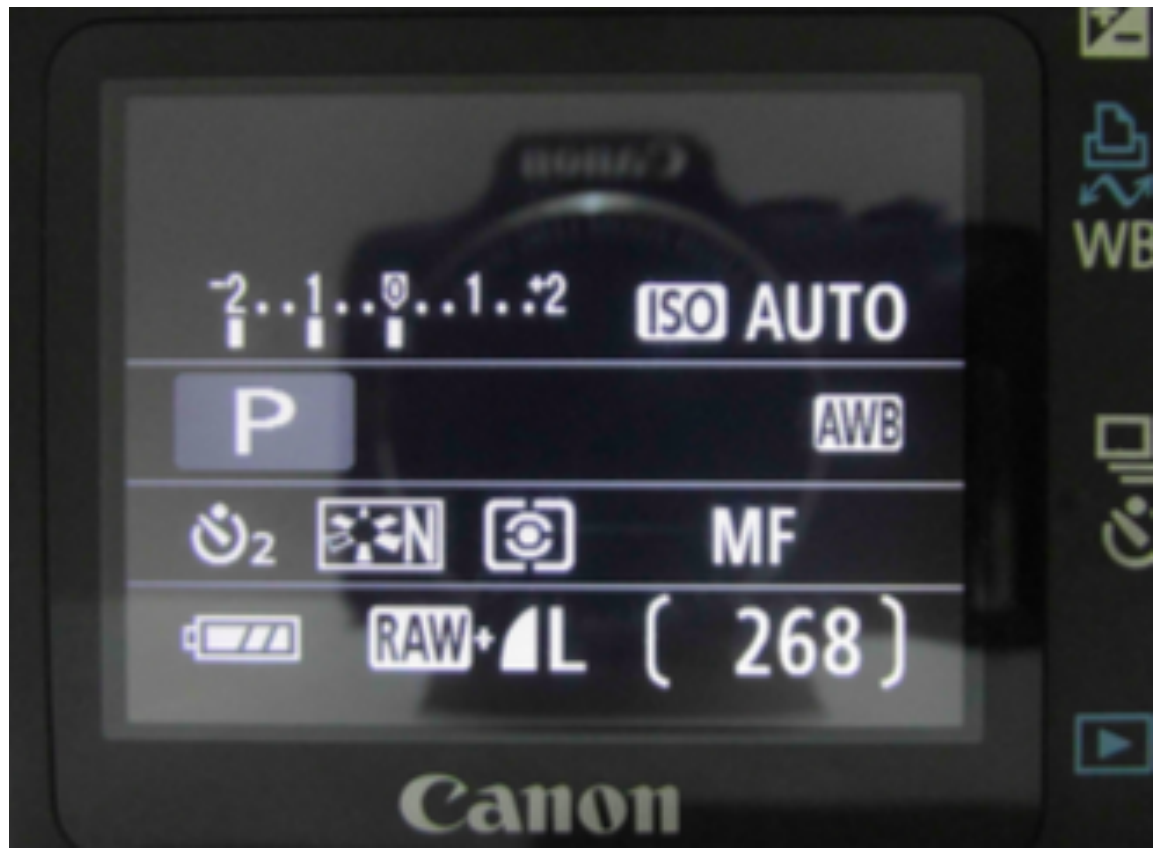

(Note: the number on the bottom right in brackets will change depending on the amount of space left on the memory card.

\section{Steps to follow when taking hemispherical photographs:}

1. Check configuration: Proper configuration of the camera, as described above, is necessary to achieve efficiency under field conditions. In general, these settings should be retained by the camera from the last time it is used. However, the automatic exposure bracketing returns to default values (no bracketing) every time you turn off the camera. 2. Sky conditions: Take photos only when all the following conditions are met:

a. No rain

b. No direct sunlight in the forest - Direct sun can damage the camera, and strong reflections make it difficult to analyze the images

c. It is earlier than 9 am or later than $3 \mathrm{pm}$, or the sky is completely overcast

3. Position: The camera should be placed on a tripod so that the lens faces up and the top of the lens is $1 \mathrm{~m}$ above the ground.

4. Orientation: Orient the camera so that the bottom of the lens (and the paper triangle on it) faces magnetic north. To do this, use the compass. Note - the magnetic compass is sensitive to metal bodies and/or batteries in the camera as well as to metal 
necklaces and cell phones, so you should be careful to keep the compass away from these objects.

5. Leveling: Level the camera so that the top of the lens is perfectly flat. Do not tilt the camera to match the slope. It is important to have the camera level according to the bubble level. You can use the cubic bubble level that attaches to the camera to do this. Once the camera is leveled, you need to check the north once more to make sure the leveling has not affected the orientation. If reorientation is required, then check the leveling again.

6. Remove the lens cap and ring: Remove both the lens cap and the ring around the fisheye. Make sure the triangular piece of paper is within the field of view of the lens. 7. Check that the lens is clean.

8. Check the focus: The lens should be on manual focus (M) and should be focused on infinity. It is easy for the focus ring to get accidentally moved when the lens cap is removed.

9. Take the photographs: With the camera turned on, press the shutter once to activate the timer and move yourself below the horizon of the fisheye lens. The camera should automatically take 3 photographs in a row, one at each of the exposure compensation settings. If it does not take three photographs, double-check the configuration. 


\section{APPENDIX B}

\section{Relative Survival of T. guayacan seedlings in August 2016}

Initially, the fertilizer shrub experiment detailed here in Chapter 3 was set up as a randomized complete block split plot design, with each study site containing two plots, one planted in guachapalí de ganado (A. saman) and the other planted in guayacan ( $T$. guayacan). Each plot contained eight split-plots, where central timber saplings were surrounded by the different combinations of fertilizer shrubs and grasses. The strong ENSO event during the dry season of 2015-2016 resulted in the loss of $46.83 \%$ of the $T$. guayacan seedlings (Fig.1). Due to limited resources, we made the decision to abandon the $T$. guayacan plots and focus our efforts on the $A$. saman plots.

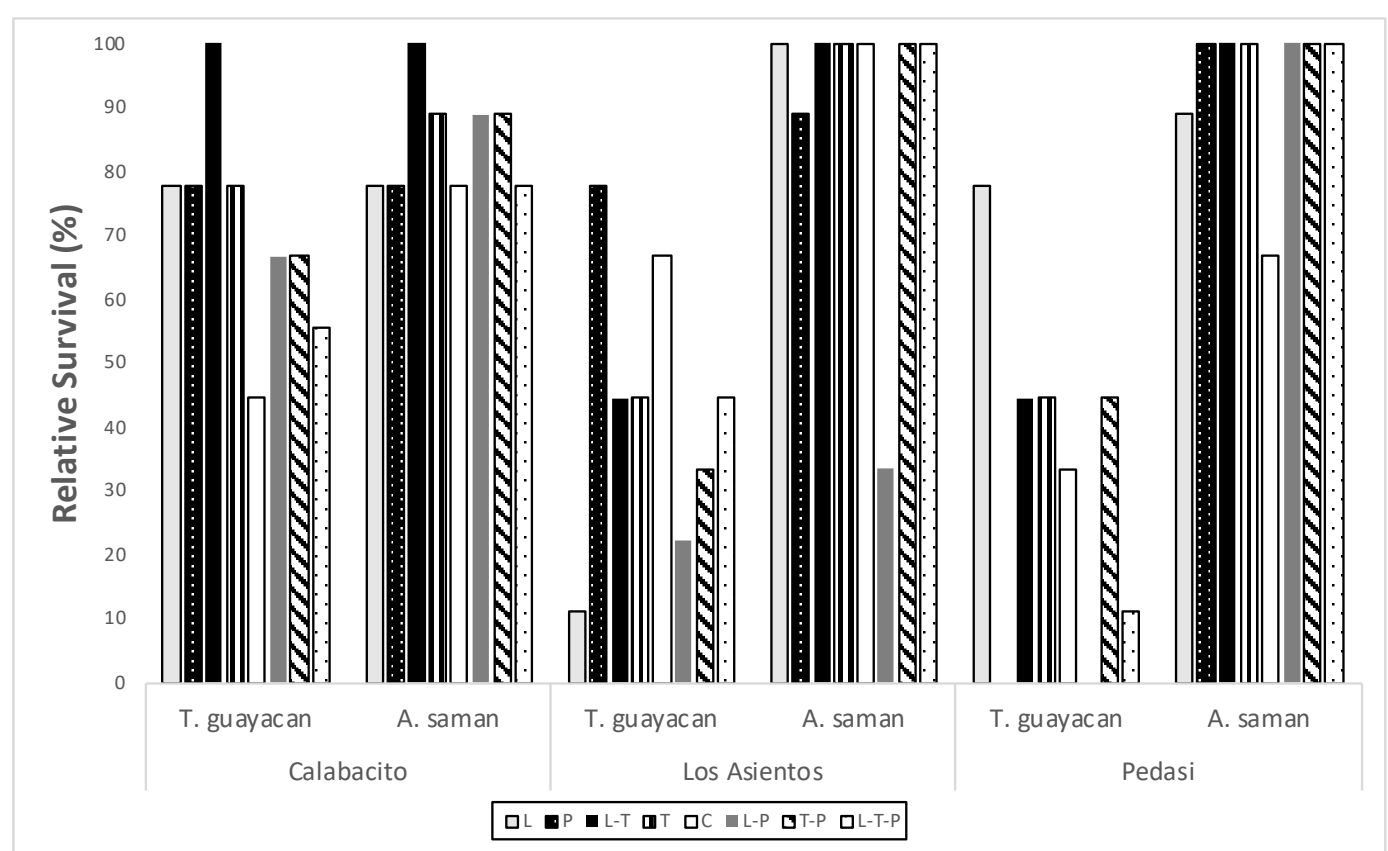

Fig. 1 Relative survival of $T$. guayacan and $A$. saman seedlings planted at Calabacito, Los Asientos, and Pedasi. The percentage of $T$. guayacan seedlings surviving was $53.17 \%$ overall in August, one year after planting. 
APPENDIX C

Images of Plantation Establishment and Research in Chapter 2

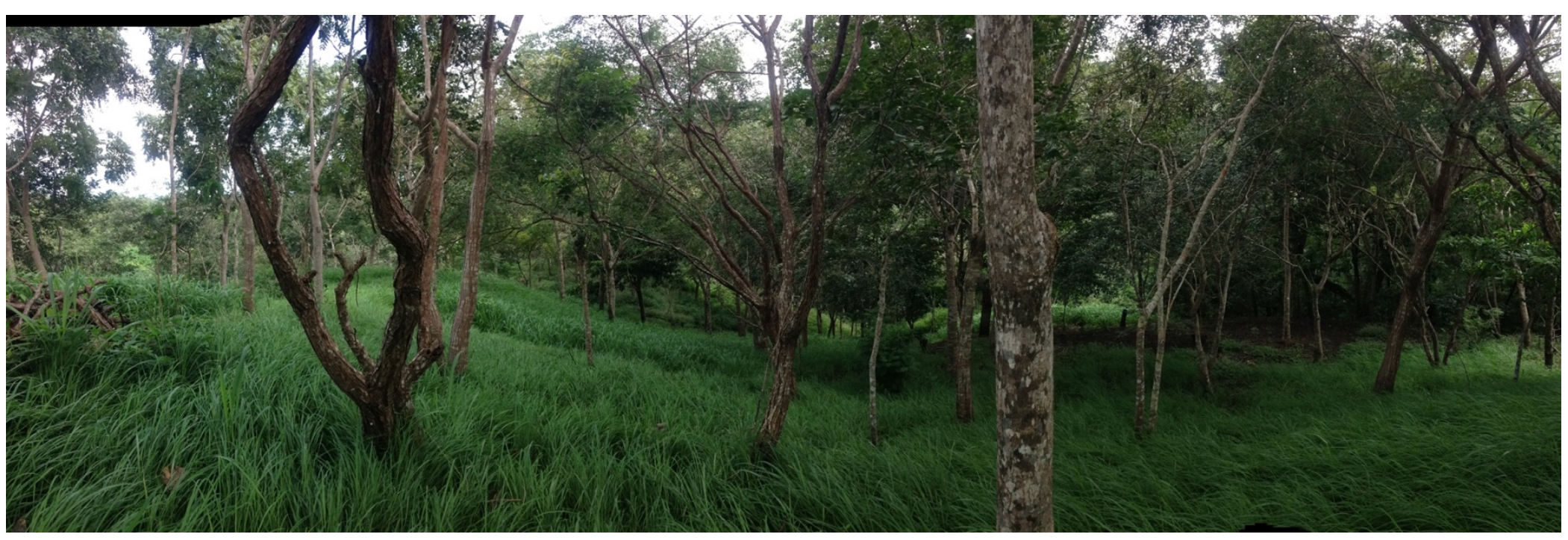

Fig. 1 Three M. maximus cultivars growing in the understory of treatment D during the wet season of 2016 at the IDB Forestal Ranch near Playa Venao, Panama. 


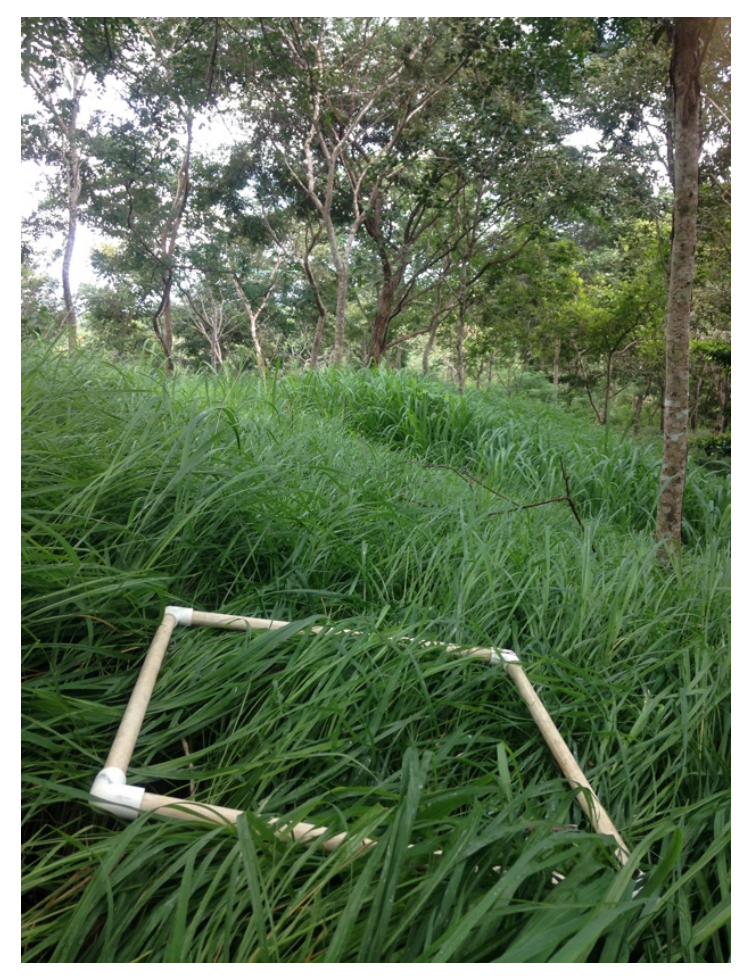

Fig. 2 The $0.5 \times 0.5 \mathrm{~m}$ square grid used to sample pasture grasses.

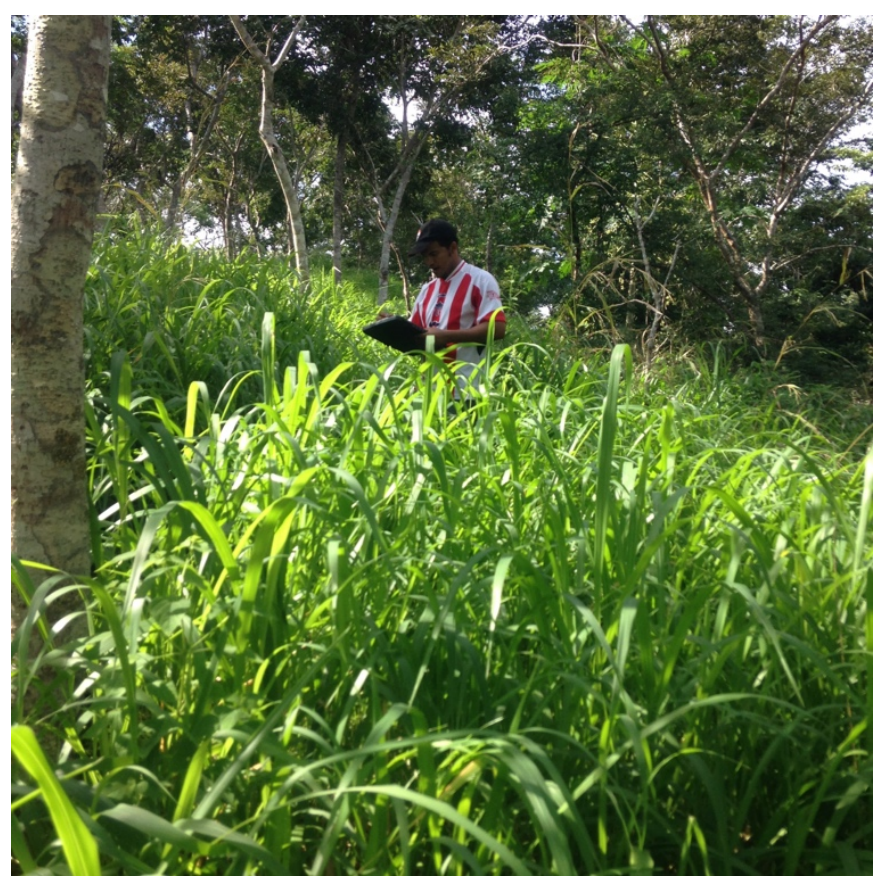

Fig. 3 Field assistant Manuel Facio helps record data during the assessment of grass dry matter production. 
APPENDIX D

Images of Plantation Establishment and Research in Chapter 3

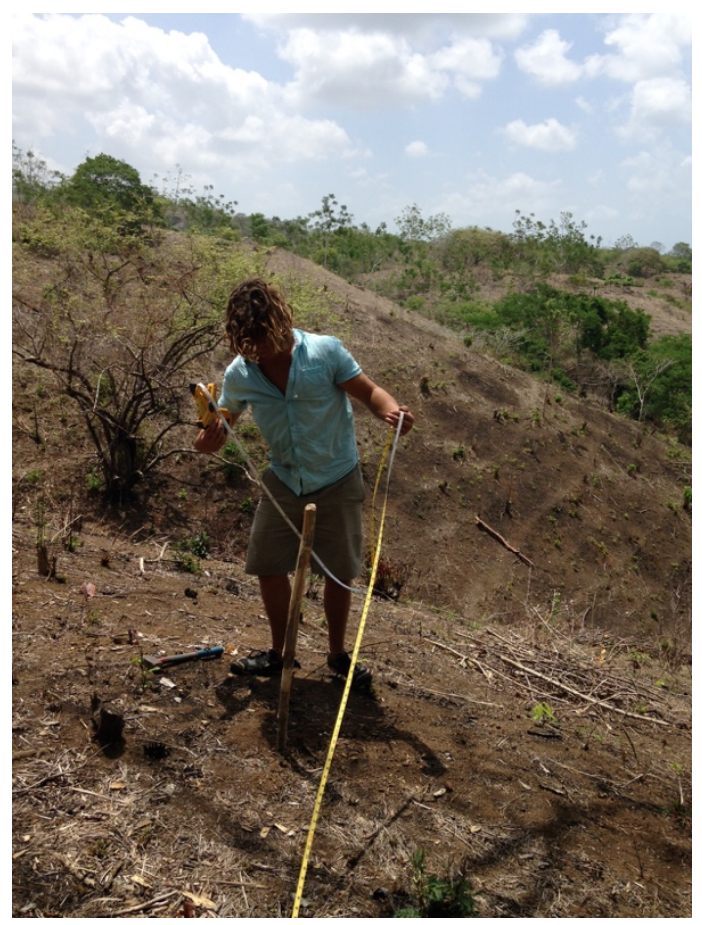

Fig. 1 Field assistant Dutch Silfer helps to demarcate treatment plots at Calabacito.

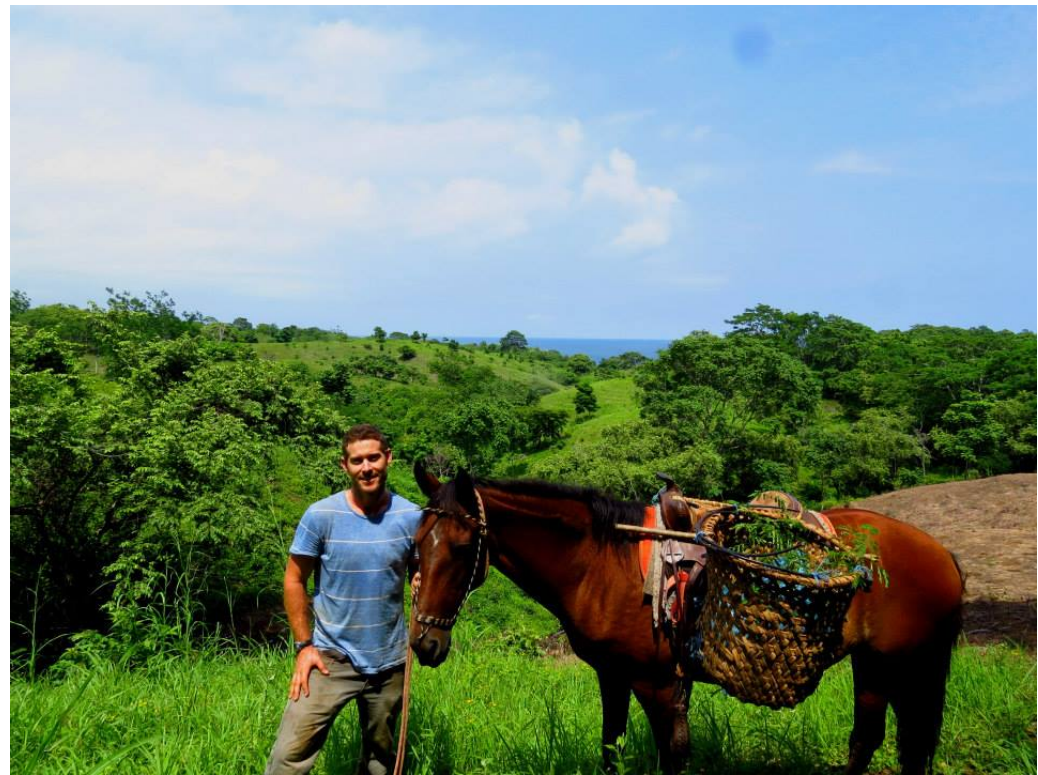

Fig. 2 Hauling seedlings via horseback to the planting site at Calabacito 


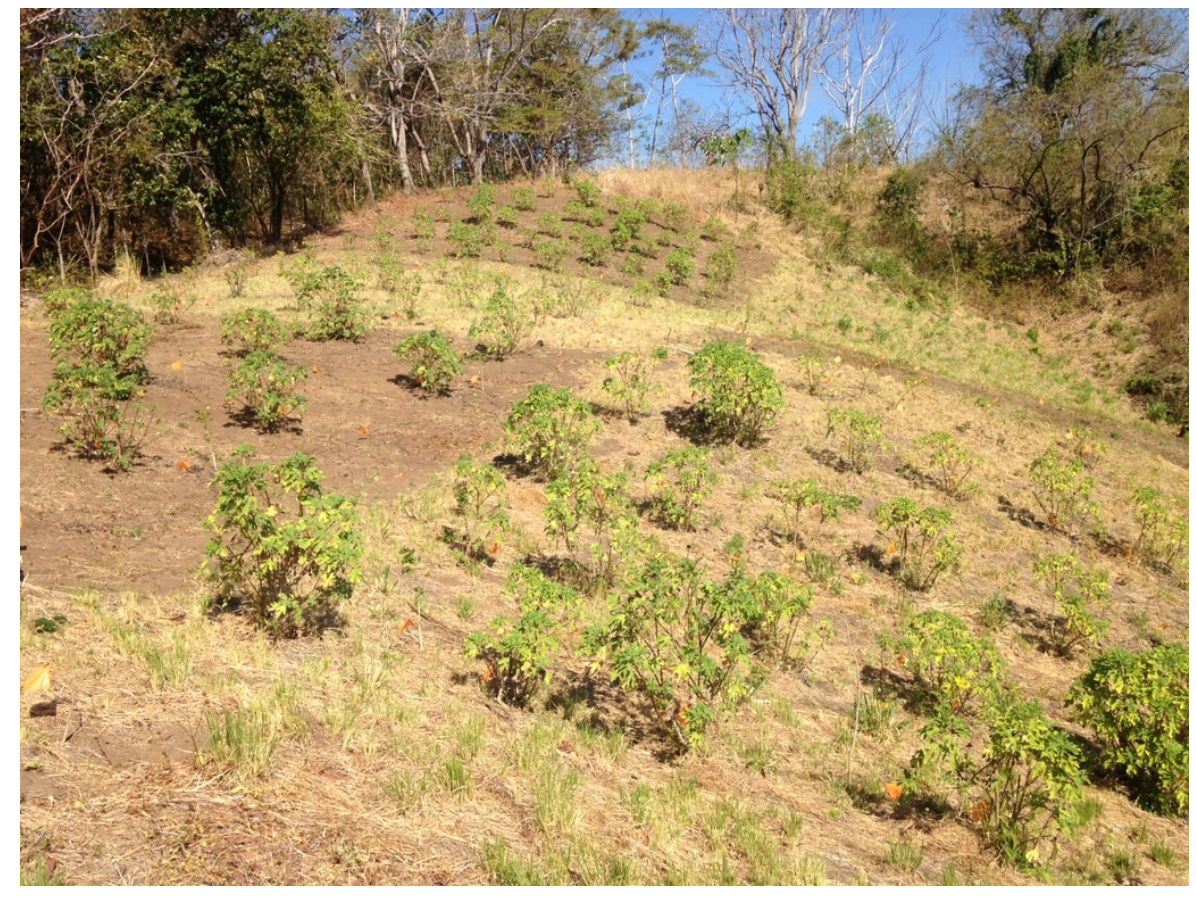

Fig. 3 Treatment plots during the dry season (March) at Calabacito. Tree seedlings are difficult to perceive in this photo, as growth and survival was inhibited by deer herbivory at this site. 


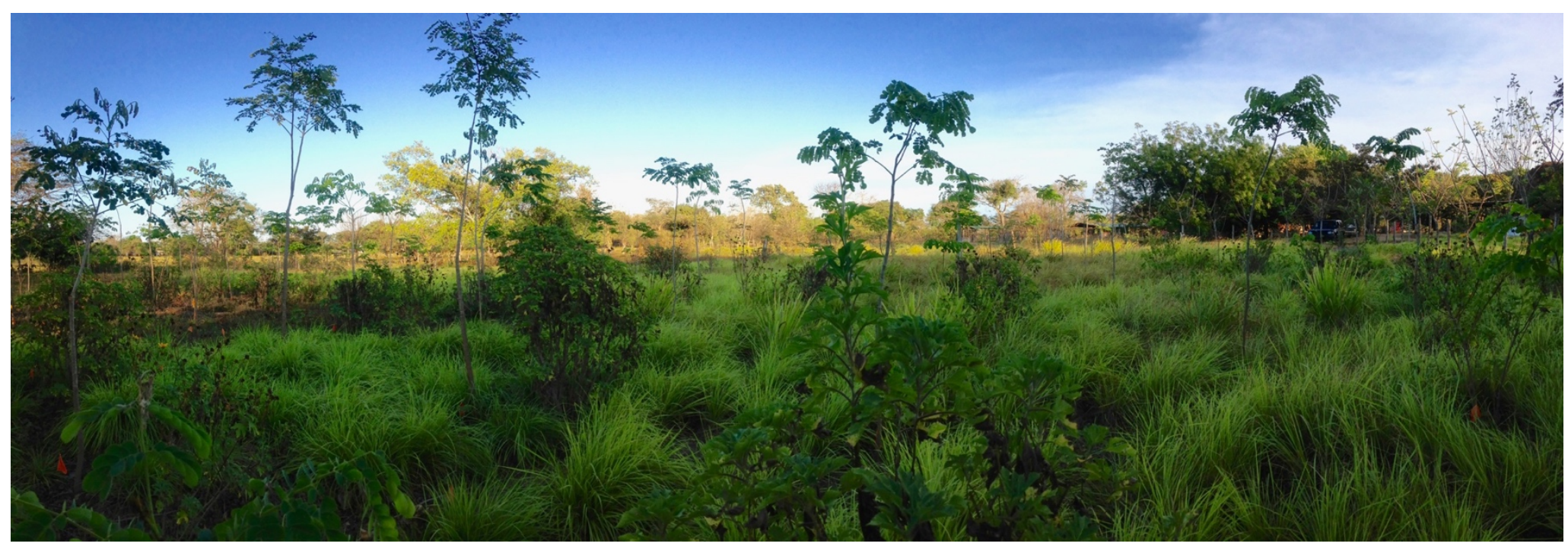

Fig. 4 Treatment plots at Pedasi during the rainy season. 


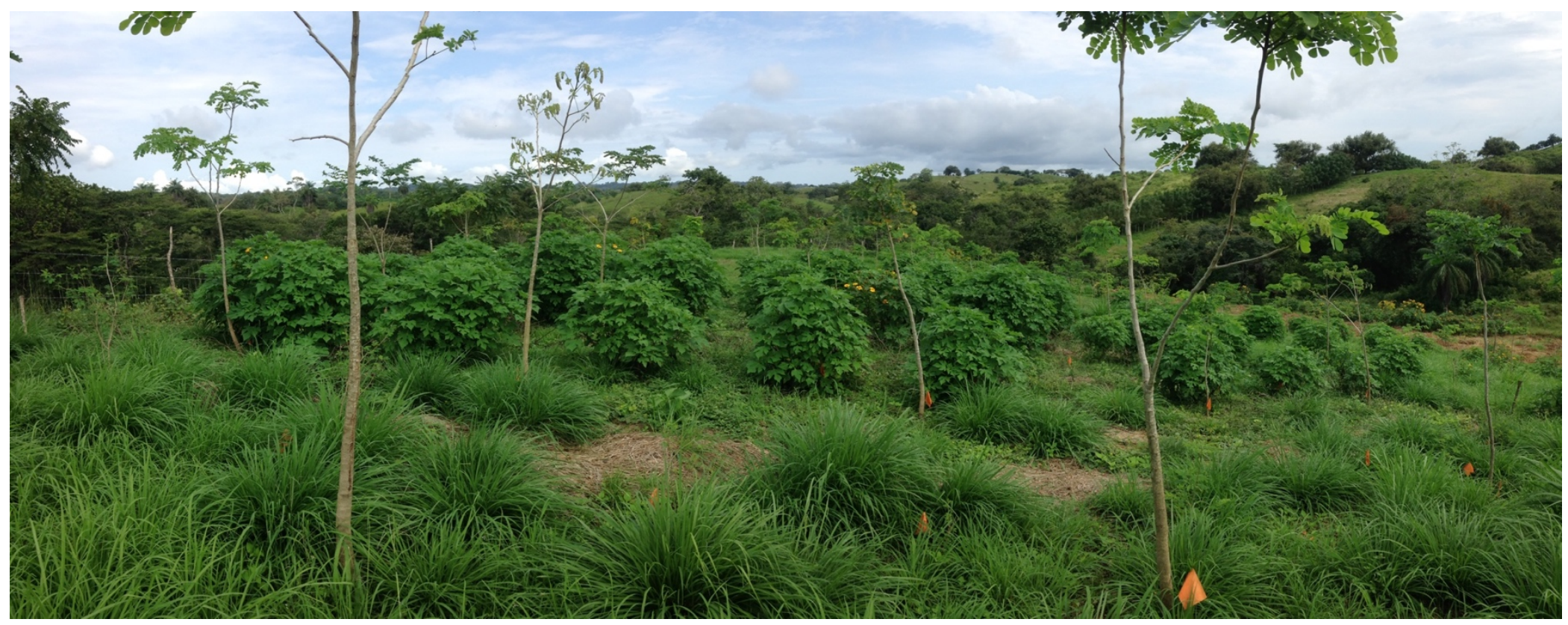

Fig. 5 Treatment plots at Los Asientos during the rainy season. 


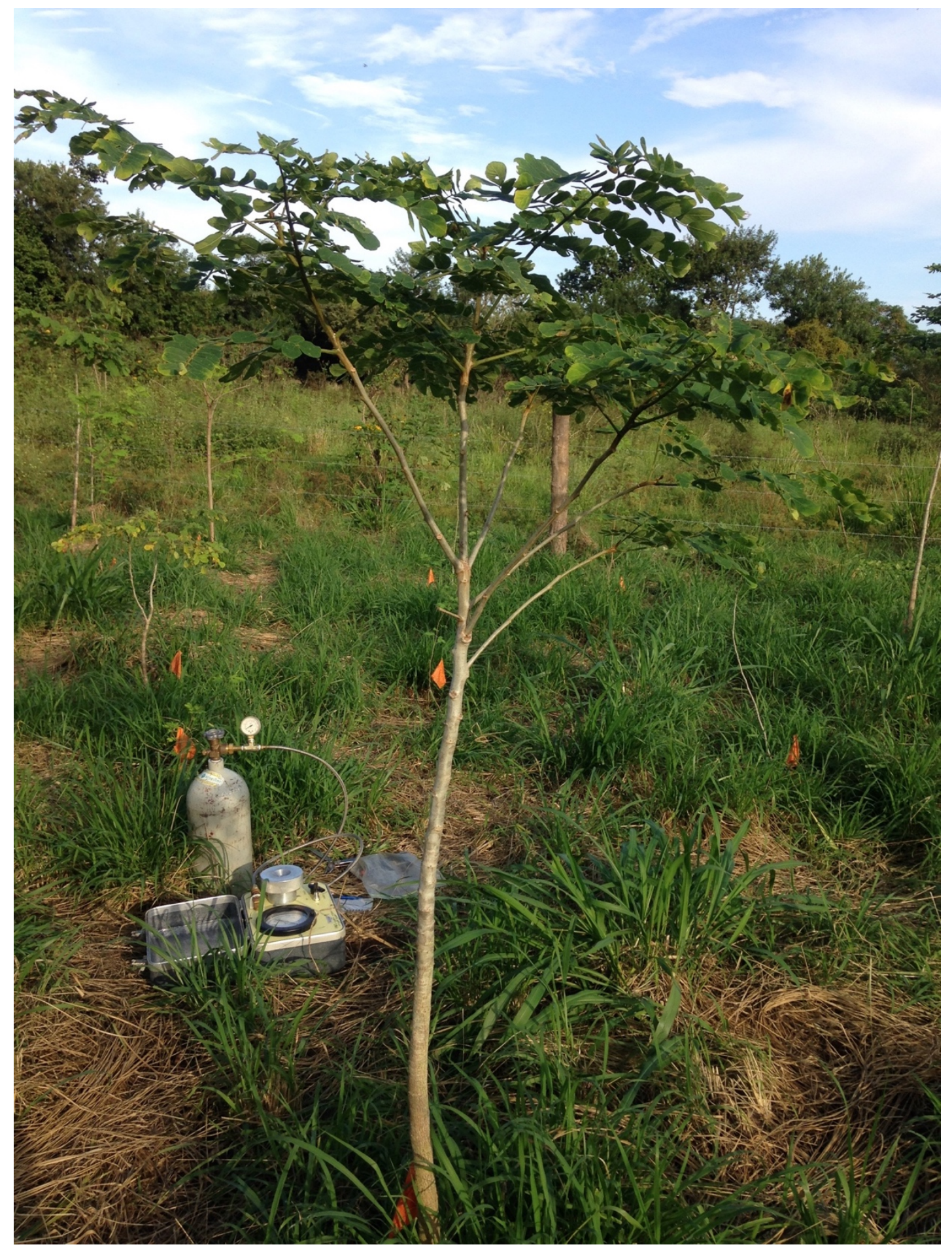

Fig. 6 Preparing to assess sapling moisture stress with the pressure chamber. 


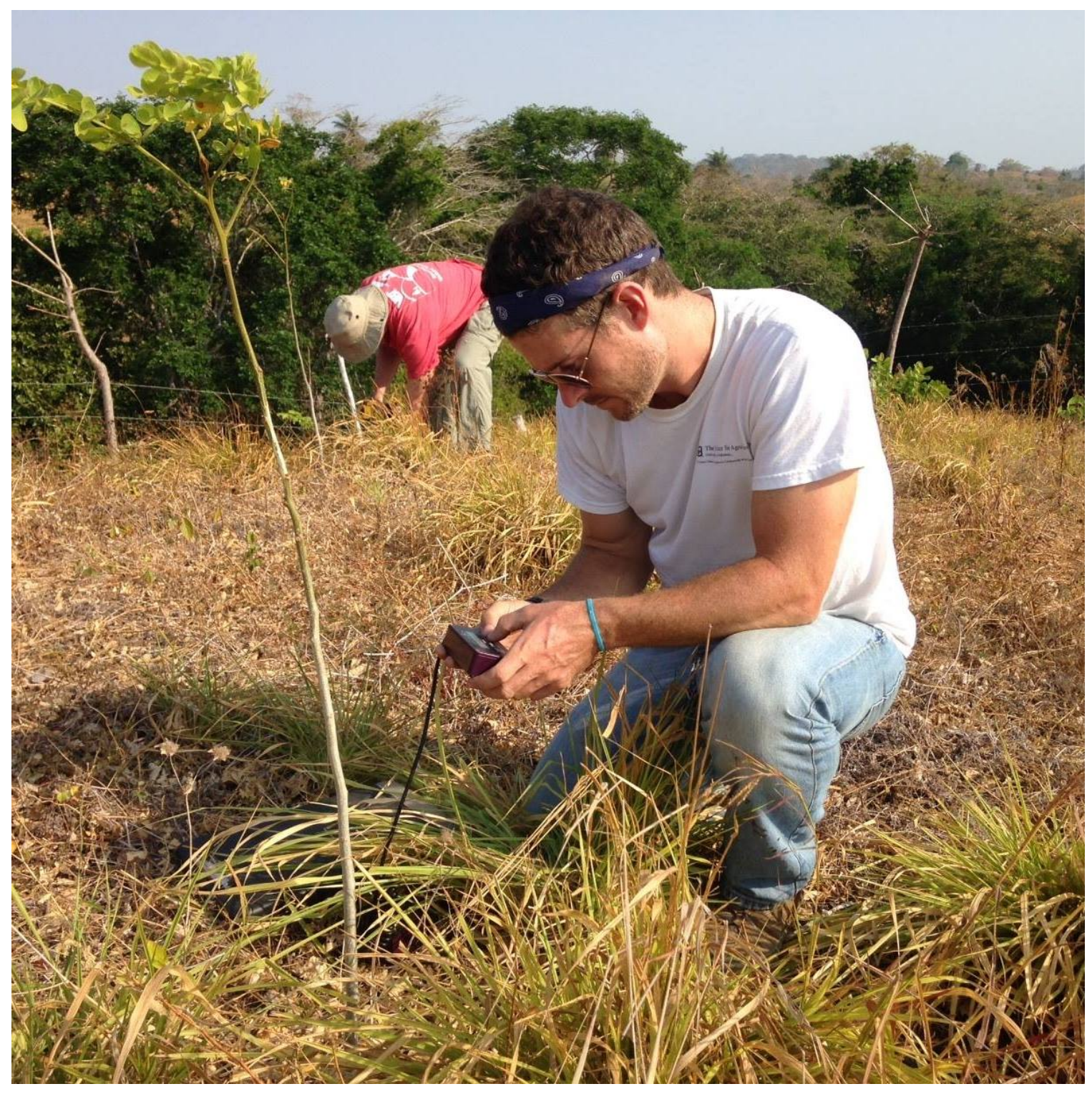

Fig. 7 Measuring soil volumetric water content at Los Asientos during the dry season. 


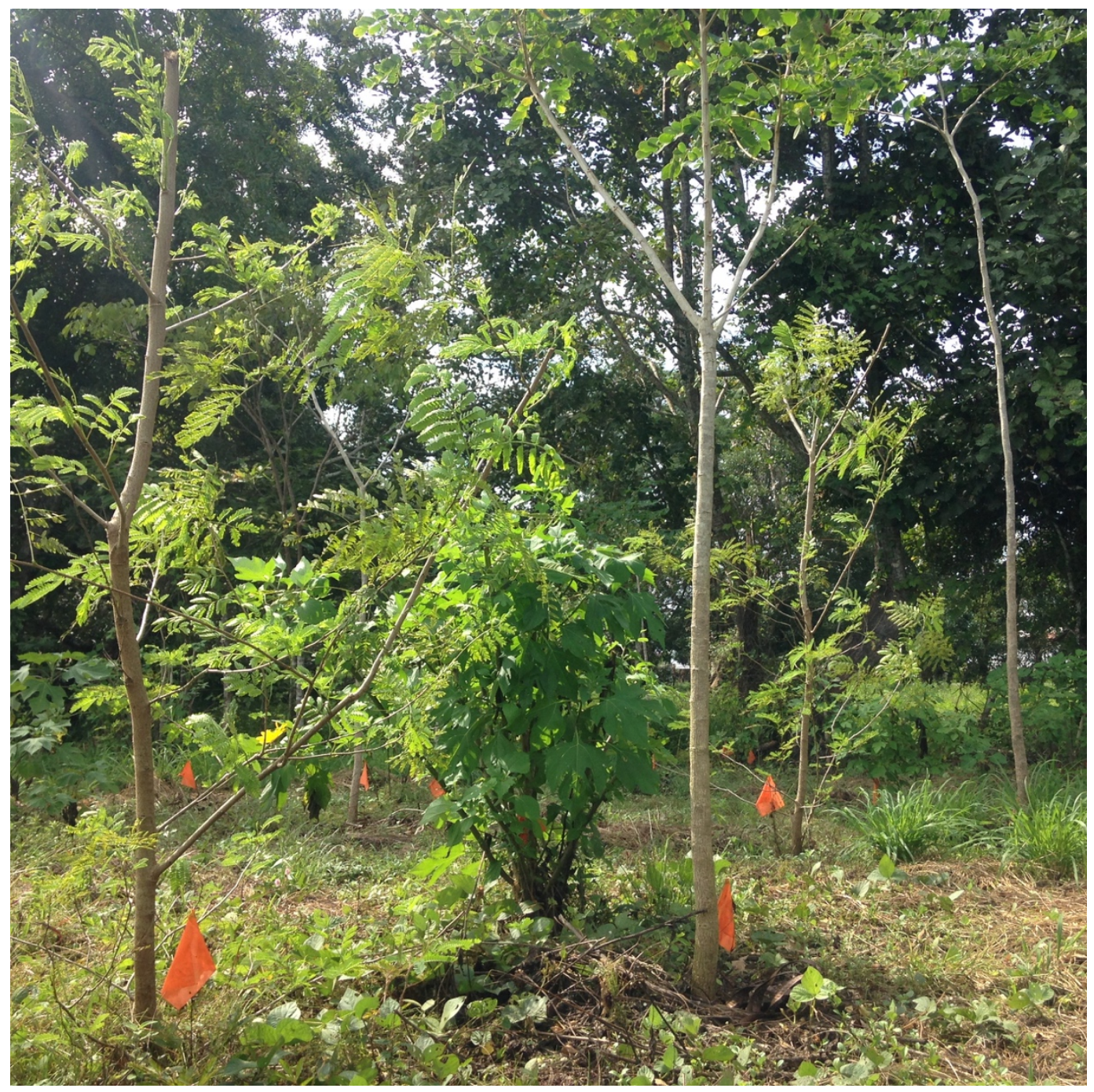

Fig. 8 Central A. saman sapling (middle) surrounded by Leucaena leucocephala (right) and Tithonia diversifolia (left). 


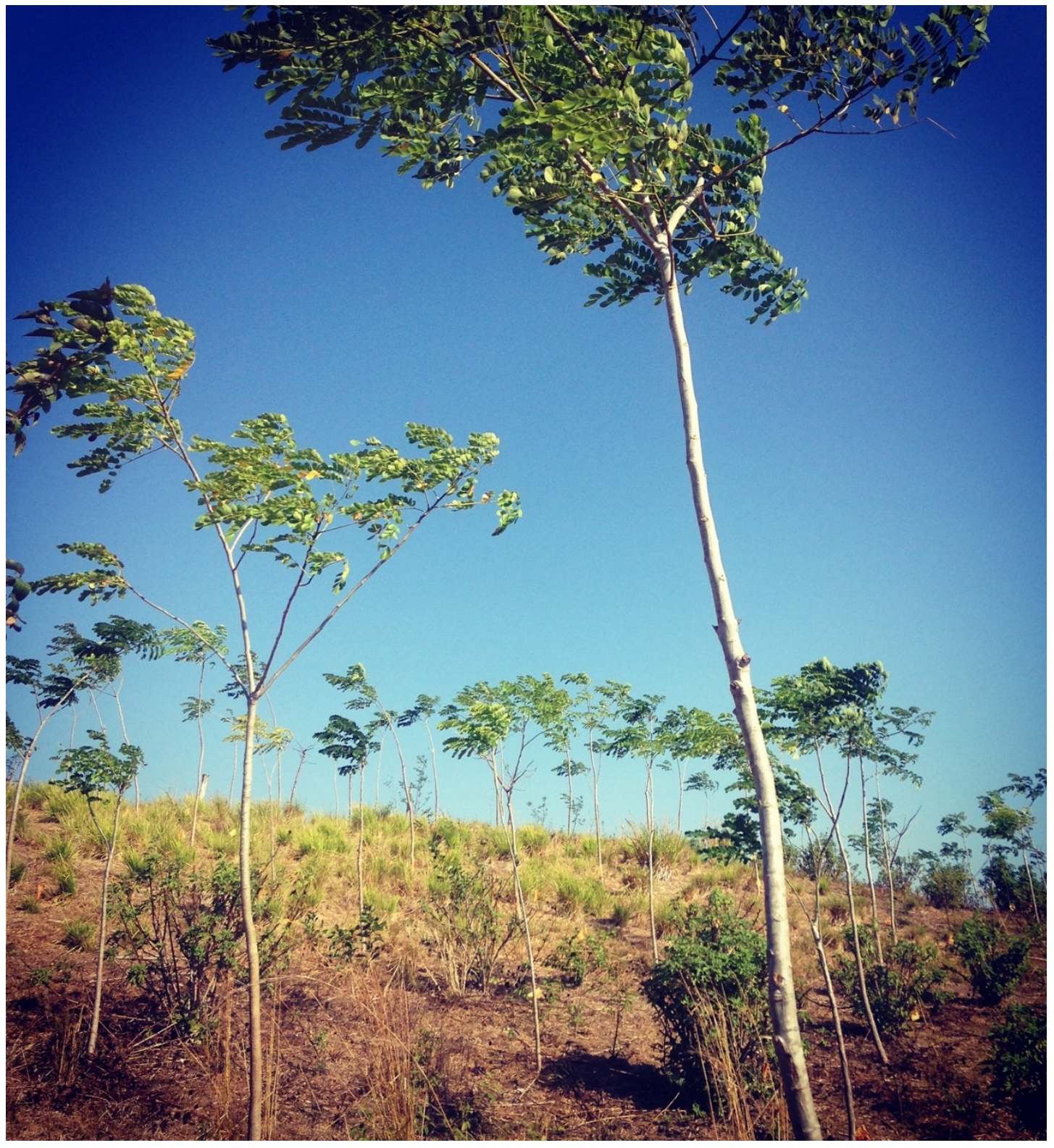

Fig. 9 A. saman saplings at Los Asientos during the dry season. 


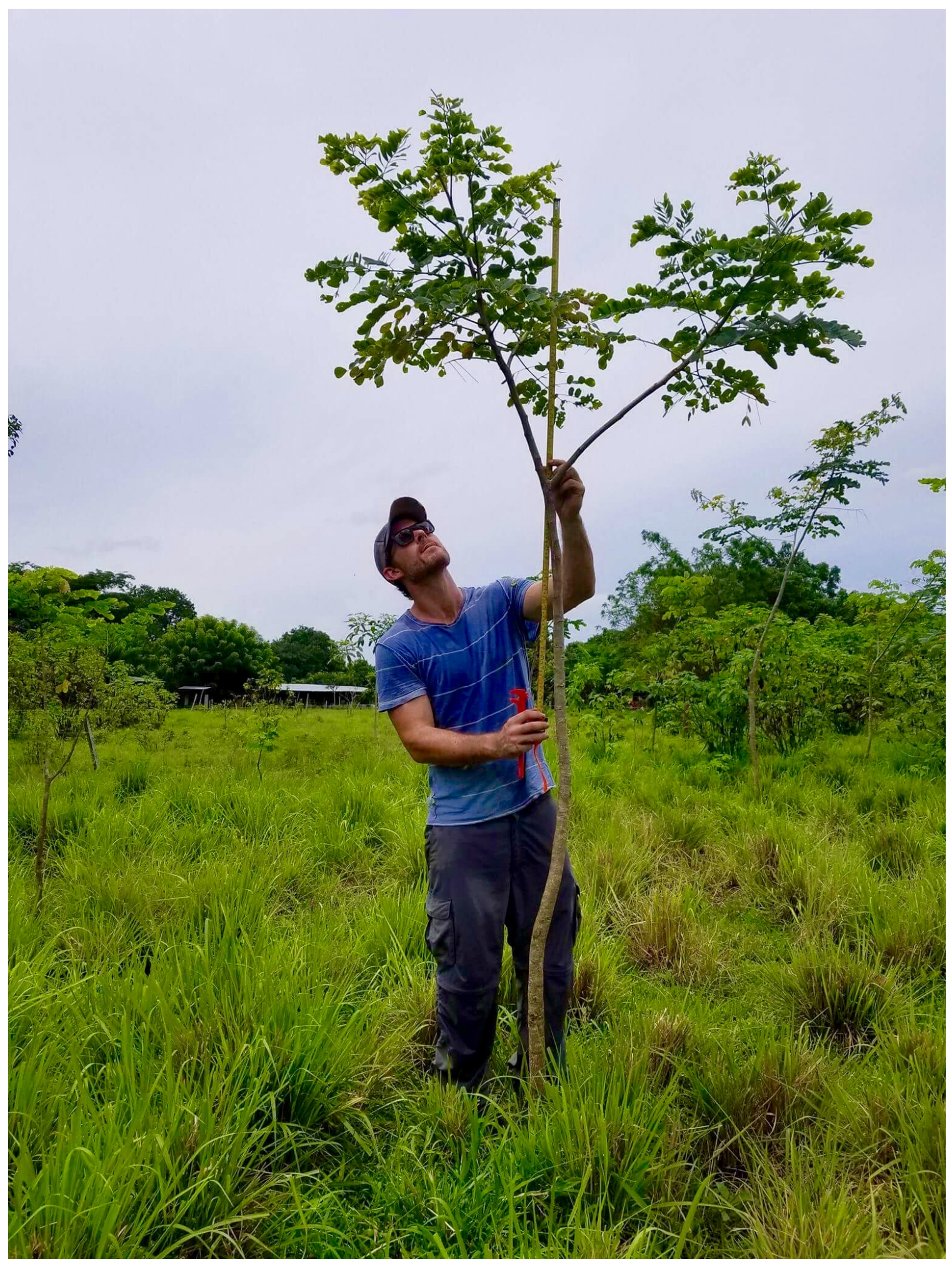

Fig. 10 Measuring sapling height at Pedasi during the rainy season. 


\section{APPENDIX E}

\section{Images of Plantation Establishment and Research in Chapter 4}

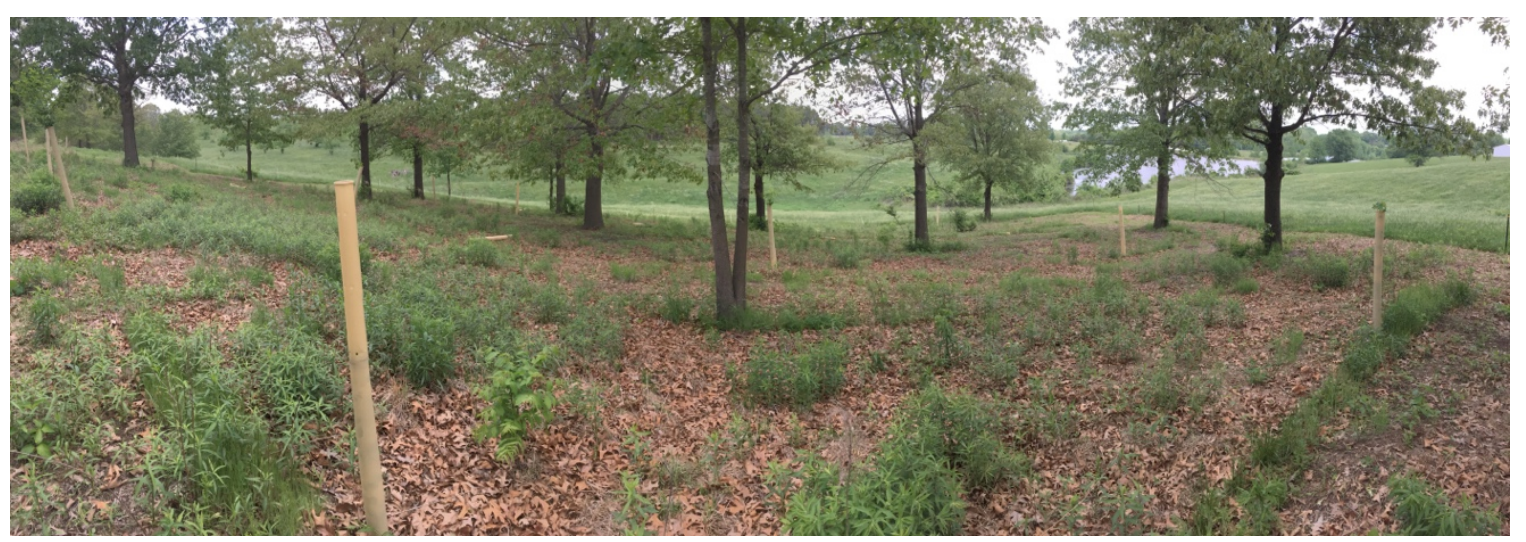

Fig. 1 M. rubra seedlings planted and protected by plastic tubing under a cherrybark oak canopy at HARC, New Franklin, Missouri.

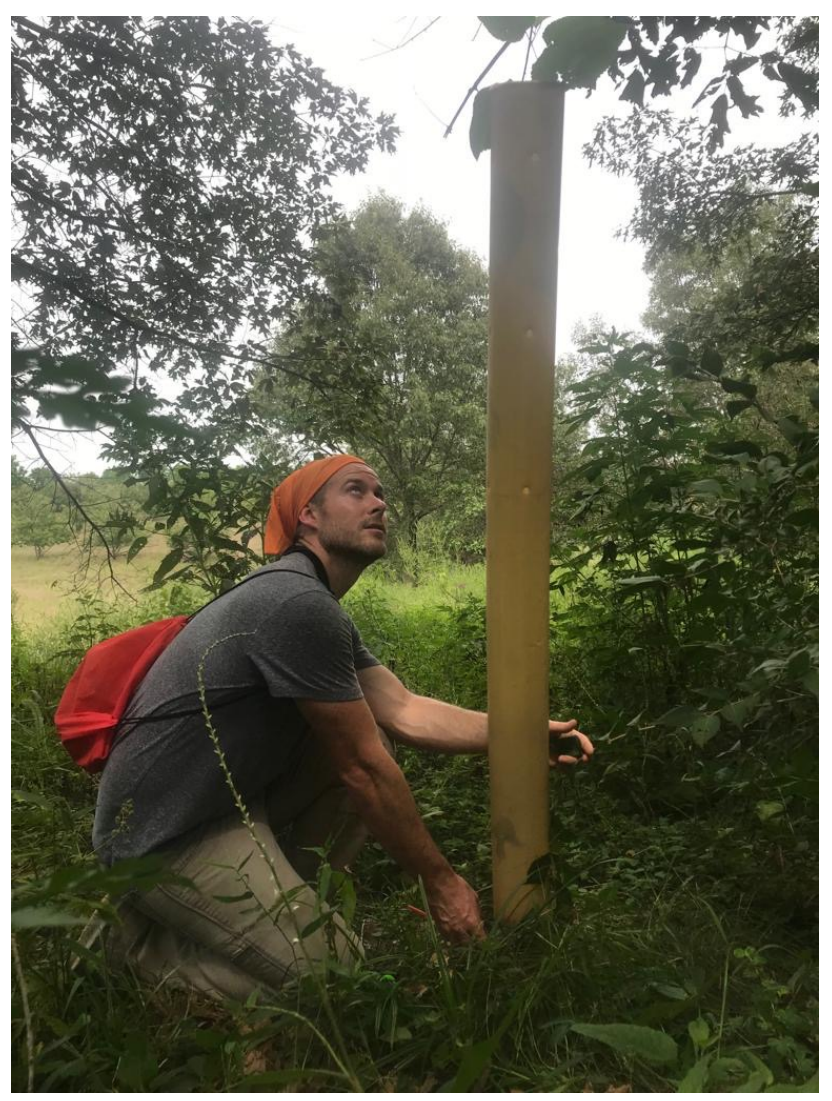

Fig. 2 Measuring the root collar diameter of a M. rubra seedling at HARC in Missouri. 


\section{VITA}

Ryan Haynes Dibala was born in Willimantic, CT, USA. He grew up in rural northeastern Connecticut where he quickly took a fascination in animals, agriculture, and the environment. His favorite subject in high school was Ecology, and remembers actively learning about the natural world on field trips to State parks with his favorite high school teacher Mr. Edmund Smith. Early on, Ryan was most interested in wildlife ecology, particularly forest management effects on wildlife populations. As a Master's student, he studied Cerulean Warbler settlement patterns in a managed forest in Southern Indiana to better understand the effects of silviculture on this threatened migratory songbird. After graduating, he longed to pursue less species-specific research and to develop questions with greater social relevance. Time spent in Latin America as a Peace Corps volunteer had Ryan yearning to conduct research with direct implications for developing socially, ecologically and economically feasible land use options for smallholding farmers in developing countries.

Over the last four years, Ryan has created the opportunity to work directly with ranchers in Panama, reforest badly degraded pastures, and explore a number of highly complex ecological processes during his doctorate work at the University of MissouriColumbia. In a time when food security and ecosystem integrity is being confronted with a changing global climate, Ryan remains passionate and optimistic about our planet's ecological and agricultural future. In the next few years, Ryan hopes to continue international development work that supports progressive, agroforestry-based alternative agriculture. 